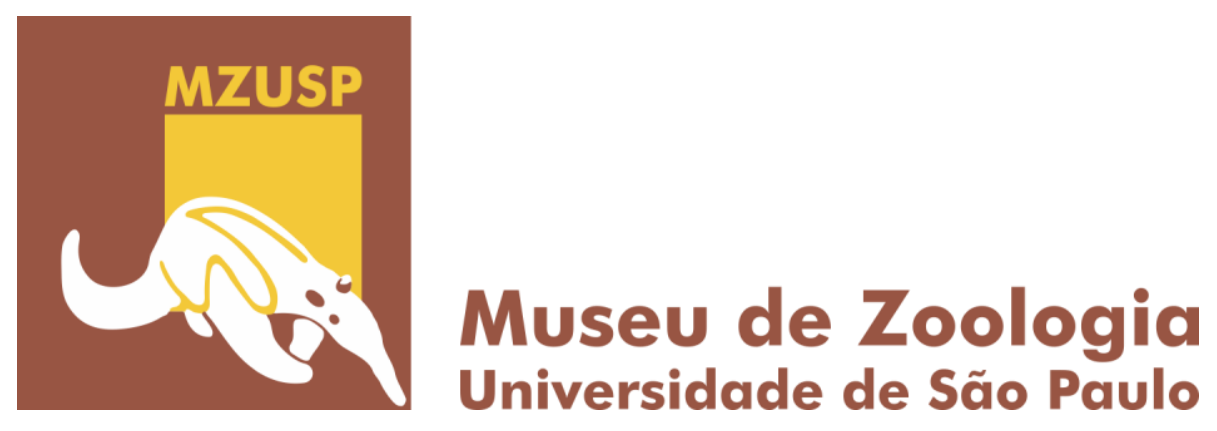

Sergio David Bolívar Leguizamón

\title{
Comparative phylogeography of Passerine birds with a circum-Amazonian distribution
}

Filogeografia comparada de Passeriformes com uma distribuição circum-Amazônica

SÃO PAULO 


\title{
Comparative phylogeography of Passerine birds with a circum-Amazonian distribution
}

\author{
Filogeografia comparada de Passeriformes com uma \\ distribuição circum-Amazônica
}

Original Version

Thesis submitted to the Graduate Program of the Museu de Zoologia da Universidade de São Paulo in partial fulfillment of the requirements for the degree of Doctor of Science (Systematics, Animal Taxonomy and Biodiversity).

Advisor: Prof. Dr. Luís Fábio Silveira

SÃo PAULO 
I do not authorize the reproduction and dissemination of this work in part or entirely by any electronic or conventional means.

Catalogação na Publicação

Serviço de Biblioteca e Documentação

Museu de Zoologia da Universidade de São Paulo

Bolívar-Leguizamón, Sergio David

Filogeografia comparada de Passeriformes com uma distribuição circum-Amazônica $=$ Comparative phylogeography of Passerine birds with a circum-Amazonian distribution/ Sergio David Bolívar Leguizamón; orientador Luiz Fabio Silveira. São Paulo, 2019.

$219 \mathrm{p}$.

Tese apresentada ao Programa de Pós-Graduação em Sistemática, Taxonomia e Biodiversidade, Museu de Zoologia, Universidade de São Paulo, 2019.

Versão original

1. Filogeografia - Passeriformes. 2. Passeriformes - distribuição 3. circum-Amazônica. I. Silveira, Luis Fábio, orient. . II. Título.

CDU 598.2(811)

CRB 8-3805 
Bolívar-Leguizamón, Sergio David

Comparative phylogeography of Passerine birds with a circum-Amazonian distribution.

Filogeografia comparada de Passeriformes com uma distribuição circum-Amazônica.

Dissertation submitted to the Graduate Program of the Museu de Zoologia da Universidade de São Paulo in partial fulfillment of the requirements for the degree of Doctor of Science (Systematics, Animal Taxonomy and Biodiversity).

Date approved:

Institution:

Prof. Dr.

Signature:

Prof. Dr.

Institution:

Decision:

Signature:

Prof. Dr.

Institution:

Decision:

Signature:

Prof. Dr.

Institution:

Decision:

Signature:

Prof. Dr.

Institution:

Decision:

Signature: 
A mi familia 


\section{Acknowledgements}

This project was funded by Coordenação de Aperfeiçoamento de pessoal de Nível Superior (CAPES, 05/2015 to 01/2016) and by Fundação de Amparo à Pesquisa do Estado de São Paulo (FAPESP 2015-16092-7, 02/2016 to 06/2019). In addition, I gratefully acknowledge financial support from the Frank M. Chapman Memorial Fund from the American Museum of Natural History (AMNH).

This work could not have been accomplished without the help and cooperation of various institutions and individuals: First, I want to thank the PhD. Luís F. Silveira, for the opportunity to continue working in the research group of Ornithology of the MZUSP, and for his continuous support during my PhD program. In the same way, I want to thank my co-adviser Gustavo A. Bravo, for his assistance in the conception and development of the project. I also thank to the staff MZUSP for helped me resolve questions and problems here at the Museum (especially Marta, Sonia, and Dione).

I want to thank the multiple collections that sent tissue samples for this project: Robb Brumfield and Donna Dittmann from LSU Museum of Natural Science Collection of Genetic Resources (LSUMNS), Mark B. Robbins from University of Kansas Biodiversity Institute (KU), John Bates and B. Marks from Field Museum of Natural History (FMNH), Christopher Milensky from the National Museum of Natural History of the Smithsonian Institute (NMNH), Alexandre Aleixo and Antonita Santana from Museu Paraense Emílio Goeldi (MPEG), Carla Suertegaray Fontana and Maiara Flores from Laboratório de Ornitologia da Pontifícia Universidade Católica do Rio Grande do Sul (PUC-RS), and the PhD Prof. Fabio Raposo do Amaral (UNIFESP). 
Thanks to the MZUSP taxidermists Marina Lima and Marcelo Felix, for the preparation of some specimens collected during the PhD. I am very grateful to Jaqueline Battilana from Laboratory of Molecular Biology (MZUSP), who help me in all processing of samples and DNA extractions. I want to thank Denis Machado, Luciana dos Santos and Taran Grant for the help in the use of the cluster of MZUSP.

Thanks to my colleagues in the laboratory (alphabetical order): Aline, Anna, Ariane, Cristiane, Deborah, Diego A., Erica P., Fabio, Fernanda, Glaucia, Karlla, Marcelo F., Marco, Marina L., Natalia, Oscar Diego, Thiago, and Vitor. Thanks to my friend Fernanda Bocalini for her collaboration in this project: "someday we will be rich!" Finally, I want to thank specially to Aline, Fernanda, Glaucia and Fabinho by the funny moments in this drama titled 'é mestrado ou doutorado?' Thanks to Aline Pepe for his help and friendship during these years.

¿Gracias a MI FAMILIA por su apoyo y cariño! 
[...] Siguió con tanta atención las peripecias del entierro que nadie dudó de que lo estaba viendo, sobre todo porque su alzada mano de arcángel anunciador se movía con los cabeceos de la carreta.

-Adiós, Gerineldo, hijo mío -gritó-. Salúdame a mi gente y dile que nos vemos cuando escampe.

Aureliano Segundo la ayudó a volver a la cama, y con la misma informalidad con que la trataba siempre le preguntó el significado de su despedida.

-Es verdad -dijo ella-. Nada más estoy esperando que pase la lluvia para morirme.

Cien años de soledad. Gabriel García Márquez 


\section{Abstract}

There are a number of common distributional patterns that have provided the foundations of our current knowledge of Neotropical biogeography. A distinctive pattern is the so-called "circumAmazonian distribution", which expands across the forested lowlands south and east of Amazonia, the Andean foothills, the Venezuelan Coastal Range, and the Tepuis. To date, there is no clear understanding of the processes giving rise to this distribution. To understand the evolutionary history of taxa exhibiting this pattern it is necessary to test biogeographic hypotheses offering mechanistic explanations. Comparative phylogeography allows more accurate phylogeographic hypotheses for these taxa, as well as better population genetic parameters. Comprehensive comparative studies aiming at unraveling the evolutionary and biogeographic mechanisms underlying the circum-Amazonian distribution have not been conducted yet, and only scarce descriptive information has been published. Therefore, the objective of this work was to elucidate the historical and biogeographic mechanisms underpinning circum-Amazonian distribution by performing comparative genomic analyses of a group of Suboscine passerines. Ultraconserved Elements (UCEs) were obtained for eight taxonomic groups to estimate population parameters and genealogical trees. For the Thamnophilidae species were inferred demographic histories with momi2. The best models of each taxon were analyzed in a comparative framework to relate them with previously proposed biogeographic hypotheses for the Neotropics and to propose plausible biogeographical scenarios for the circum-Amazonian pattern. The circum-Amazonian distributional pattern has two main phylogeographic units: an Andean (plus Central America region) and an eastern-forested region (Atlantic Forest ecoregion, forested areas around southeast of Amazonia), interconnected by a northern and southern corridor, allowing biotic interchanges 
between them (mainly from the southern) and hybridization. Species-tree analyses recovered (a) an Andean clade with two Andean subgroups in the northern Peru and central Andes, and (b) an eastern-forested clade including northern and central/southern Atlantic Forest subgroups. The demographic histories of the Thamnophilidae taxa suggest that diversification of the circumAmazonian taxa have a strong influence of climatic fluctuations during the Pleistocene, with interconnected refugia allowing phenotypic/genetic differentiation but maintaining a considerable level of gene flow during varying dry/cool and warm/humid periods. In addition, the results of this work opened interesting taxonomic questions about some taxa that could be covered in the future (T. ruficapillus/torquatus complex, Xiphocolaptes complex). 


\section{Resumo}

Existe um número de padrões de distribuição comuns que forneceram os fundamentos do nosso atual conhecimento da Biogeografia Neotropical. Um padrão distintivo é o chamado padrão de distribuição circum-Amazônico, apresentado por grupos filogeneticamente relacionados habitando as florestas de baixada ao sul-leste da Amazônia, as encostas úmidas dos Andes, a área costeira da Venezuela e os Tepuis. Atualmente não existe um entendimento claro dos processos que deram surgimento a este padrão de distribuição. Para compreender a história evolutiva dos táxons exibindo este tipo de padrão é necessário testar hipóteses biogeográficas que ofereçam explicações mecanicistas. A Genômica comparativa permite hipóteses filogeográficas mais exatas para estes táxons, assim como melhores parâmetros demográficos. Estudos comparativos abrangentes visando em esclarecer os mecanismos evolutivos e biogeográficos relacionados a distribuição circum-Amazônica não tem sido elaborados ainda, e só informação descritiva escassa tem sido publicada. Portanto, os objetivo fundamental do projeto foi elucidar os mecanismos históricos e biogeográficos subjacentes à distribuição circum-Amazônica desenvolvendo analises genômicos comparativos de um grupo de Passeriformes Suboscines. Dados do gene ND2 e de Elementos Ultraconservados (UCEs) foram obtidos de oito grupos taxonômicos para estimar parâmetros populacionais e arvores genealógicas. Histórias demográficas foram inferidas só para as espécies da família Thamnophilidae usando momi2. Os melhores modelos de cada táxon foram analisados num marco comparativo para relaciona-os ás hipóteses biogeográficas propostas para o Neotrópico e propor cenários possíveis para a distribuição circum-Amazônica. O padrão de distribuição circum-Amazônico possui duas unidades filogeográficas principais: uma unidade Andina (incluindo a região de Centro América) e uma segunda unidade incluindo as regiões florestais do 
leste (Mata Atlântica, áreas florestais ao sudeste da Amazônia). Estas unidades estão interconectadas por corredores ao norte e sul da distribuição, permitindo intercâmbios de biota entre elas (principalmente pelo corredor sul). SNAPP identificou o clado Andino subdividido em norte do Peru e central Andes, e um segundo clado das Florestas do Leste incluindo dois subgrupos, um do norte e outro do centro-sul da Mata Atlântica. As histórias demográficas dos Thamnophilidae sugerem que a diversificação na distribuição circum-Amazônica foi altamente influenciada pelas flutuações climáticas durante o Pleistoceno, com refúgios interconectados gerando diferenciação fenotípica/genética mas mantendo certo grau de fluxo gênico nos períodos secos/frios e quentes/húmidos. Adicionalmente, algumas questões taxonômicas sobre alguns táxons estudados que poderiam ser estudadas no em futuros estudos (o complexo $T$. ruficapillus/torquatus e o gênero Xiphocolaptes). 


\section{List of Figures}

Chapter I. Out of northeastern Brazil: demographic and evolutionary history of the Variable Antshrike, Thamnophilus caerulescens (Aves, Thamnophilidae).

Figure 1. (a) Map showing the samples collected of T. caerulescens (codes of samples in Table S1.). (b) median-joining network depicting relationships among the haplotypes in T. caerulescens.

Figure 2. Demographic models tested in momi2 for the clusters identified for T. caerulescens....69

Figure 3. (a) Bayesian reconstruction and divergence times for $T$. caerulescens. (b) Clusters identified by DAPC in T. caerulescens. (c) Graphical representation of admixture estimates of three clusters in $T$. caerulescens. Estimated admixture coefficients using sNMF using $\mathrm{K}=3$ and alpha $=100$ (cross-entropy $=0,379352)$

Figure 4. (a) Species trees inferred by SNAPP for the T. caerulescens data. (b) Demographic reconstruction with the best model for the complete matrix of SNPs (324 loci). (c) Demographic reconstruction with the best model for the incomplete matrix of SNPs $(2,036$ loci)............71

Figure 5. Plausible scenarios of diversification of $T$. caerulescens, with the migration pulses inferred by momi2. (a) Best model in the complete matrix of SNPs (324 loci). (b) Best model in the incomplete matrix of SNPs $(2,036$ loci $)$ .72 
Figure S1a. Graphical representation of all models tested in momi2 (part 1)

Figure S1b. Graphical representation of all models tested in momi2 (part 2) ..................74

Figure S2. Topologies reconstructed for the mtDNA data of T. caerulescens. (a) Maximum Likelihood in RAxML. (b) Bayesian inference with BEAST .............................75

Figure S3. Clusters identified with the incomplete matrix for T. caerulescens. The central Andean samples can be separated in a southern Peru-Bolivia and a central Peru subgroups..............76

Figure S4. DAPC depicting a clinal pattern in the central Andean samples of T. caerulescens. (a)

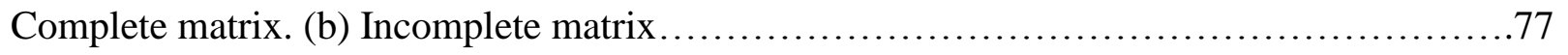

Figure S5. Values of cross-entropy for six values of $\alpha(1,10,50,100,500,1000)$. (a) Complete

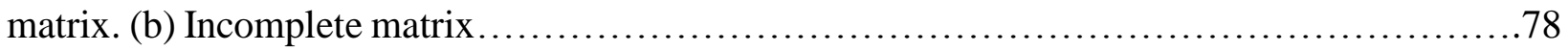




\section{Chapter II. Comparative phylogeography of passerine birds with a circum-Amazonian distribution.}

Figure 1. Distribution of Dysithamnus mentalis (BirdLife International, 2019), a circumAmazonian species (sensu Remsem et al., 1991)....

Figure 2. Basic models tested for the four species of Thamnophilidae. Divergence times (red square). Events of migration (blue arrows). Bottleneck events (green circles). All models tested were variations of these basic models, these variations consisted in change number of events and direction of the migrations

Figure 3a. Divergence times among intraspecific lineages for the four species of Thamnophilidae. Blue bars are confidence intervals of divergence time estimates. Collapsed clades indicate geographical clusters identified by DAPC/sNMF: Red: northern Atlantic Forest; Green: centralsouthern Atlantic Forest; Pink: Andean (or central Andean); Brown-Yellow: forests southeast of the Amazon; Pale-Blue: southern Peru-Bolivia region; Blue: Outgroups .135

Figure 3b. Divergence times among intraspecific lineages for L. nematura, P. rufum, and the Xiphocolaptes complex. Blue bars are confidence intervals of divergence time estimates. Collapsed clades indicate geographical clusters identified by DAPC/sNMF: Red: northern Atlantic Forest; Green: central-southern Atlantic Forest; Pink: Andean (or central Andean); Brown-Yellow: forests southeast of the Amazon; Pale-Blue: southern Peru-Bolivia region; Gray: Tepuis-Central America; Yellow: Amazonian region; Blue: Outgroups..................................136 
Figure 3c. Divergence times among intraspecific lineages for P. mystaceus. Blue bars are confidence intervals of divergence time estimates. Collapsed clades indicate geographical clusters identified by DAPC/sNMF: Red: northern Atlantic Forest; Green: central-southern Atlantic Forest; Pink: Andean (or central Andean); Brown-Yellow: forests southeast of the Amazon; Blue: Outgroups 137

Figure 4 (page 1). Results of DAPC and find.cluster() analyses for the genomic data (UCEs) of the Thamnophilid species. (a) D. mentalis. (b) T. caerulescens. (c) T. palliatus/tenuepunctatus complex. (d) T. ruficapillus/torquatus complex.

Figure 4 (page 2). Results of DAPC and find.cluster() analyses for the genomic data (UCEs). (e) L. nematura. (f) P. rufum. (g) P. mystaceus. (h) Xiphocolaptes complex

Figure 5 (page 1). Results of sNMF analysis for the genomic data (UCEs) of the Thamnophilid species. (e) D. mentalis. (f) T. caerulescens. (g) T. palliatus/tenuepunctatus. (h) $T$. ruficapillus/torquatus.

Figure 5 (page 2). Results of sNMF analysis for the genomic data (UCEs). (e) L. nematura. (f) $P$. rufum. (g) P. mystaceus. .141

Figure 5 (page 3). Results of sNMF analysis for the genomic data (UCEs). (h) Xiphocolaptes complex 
Figure 6a. Values of the cross-entropy criterion for the sNMF runs ( $\operatorname{six} \alpha$ values). Green: $\alpha=1$; Red: $\alpha=10$; Brown-Yellow: $\alpha=50$; Pink: $\alpha=100$; Gray: $\alpha=500$; Blue: $\alpha=1000 \ldots \ldots \ldots \ldots \ldots \ldots 143$

Figure 6b. Values of the cross-entropy criterion for the sNMF runs ( $\operatorname{six} \alpha$ values). Green: $\alpha=1$; Red: $\alpha=10$; Brown-Yellow: $\alpha=50$; Pink: $\alpha=100$; Gray: $\alpha=500$; Blue: $\alpha=1000 \ldots \ldots \ldots \ldots \ldots \ldots 14$

Figure 7a. Species trees inferred by SNAPP for the thamnophilid taxa data. Red: northern Atlantic Forest; Green: central-southern Atlantic Forest; Pink: Andean (or central Andean); Brown-Yellow: forests southeast of the Amazon; Pale-Blue: southern Peru-Bolivia region; Blue:

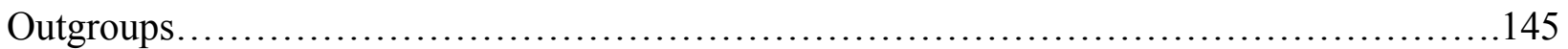

Figure 7b. Species trees inferred by SNAPP for the thamnophilid taxa data. Red: northern Atlantic Forest; Green: central-southern Atlantic Forest; Pink: Andean (or central Andean); Brown-Yellow: forests southeast of the Amazon; Pale-Blue: southern Peru-Bolivia region; Blue: Outgroups. Numbers in the figures represents the species in the Xiphocolaptes complex....................146

Figure 8. Best models inferred by momi2 for the foyr thamnophilid taxa. Red: northern Atlantic Forest; Green: central-southern Atlantic Forest; Pink: Andean (or central Andean); Brown-Yellow: forests southeast of the Amazon; Pale-Blue: southern Peru-Bolivia region......................147

Figure 9. Plausible scenarios of diversification and migration pulses inferred by momi2 for the $D$. mentalis and the T. palliatus/teunuepunctatus complex. Red: northern Atlantic Forest; Green: 
central-southern Atlantic Forest; Pink: Andean (or central Andean); Brown-Yellow: forests southeast of the Amazon; Pale-Blue: southern Peru-Bolivia region... .148

Figure 10. Plausible scenarios of diversification and migration pulses inferred by momi2 for $T$. caerulescens. (a) Complete matrix of SNPs (324 loci). (b) Incomplete matrix of SNPs (2,036 loci). Red: northern Atlantic Forest; Green: central-southern Atlantic Forest; Pink: Andean (or central Andean) region

Figure 11. Plausible scenarios of diversification and migration pulses inferred by momi2 for $T$. ruficapillus/tenuepunctatus complex. Red: northern Atlantic Forest; Green: central-southern Atlantic Forest; Pink: Andean (or central Andean) region. 150

Figure S1. median-joining network depicting relationships among the haplotypes in the thamnophilid taxa. (a) D. mentalis. (b) T. caerulescens. (c) T. palliatus/tenuepunctatus complex. (d) T. ruficapillus/torquatus complex. Red: northern Atlantic Forest; Green: central-southern Atlantic Forest; Pink: Andean (or central Andean); Brown-Yellow: forests southeast of the Amazon; Pale-Blue: southern Peru-Bolivia region; Gray: Tepuis-Central America; Yellow: Amazonian region 151

Figure S2. median-joining network depicting relationships among the haplotypes in (a) $L$. nematura. (b) P. rufum. (c) P. mystaceus. Red: northern Atlantic Forest; Green: central-southern Atlantic Forest; Pink: Andean (or central Andean); Brown-Yellow: forests southeast of the 
Amazon; Pale-Blue: southern Peru-Bolivia region; Gray: Tepuis-Central America; Yellow: Amazonian region.................................................................... 152

Figure S3. median-joining network depicting relationships among the haplotypes in

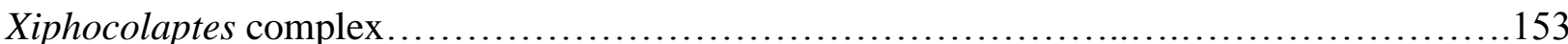

Figure S4. Phylogenetic reconstruction for D. mentalis (Maximum Likelihood) 154

Figure S5. Phylogenetic reconstruction for (a) T. caerulescens. (b) T. palliatus/tenuepunctatus.

(c) T. ruficapillus/torquatus (Maximum Likelihood)..... 155

Figure S6. Phylogenetic reconstruction for (a) L. nematura. (b) P. rufum. (c) P. mystaceus (Maximum Likelihood) 156

Figure S7. Phylogenetic reconstruction for Xiphocolaptes complex (Maximum

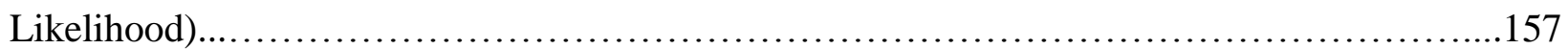

Figure S8. Alternative scenarios tested in SNAPP for (a) T. palliatus/tenuepunctatus. (b) $T$. ruficapillus/torquatus. (c) L. nematura. (d) P. mystaceus..... 158

Figure S9. Alternative scenarios tested in SNAPP for Xiphocolaptes complex 159 


\section{Contents}

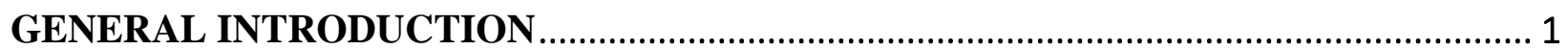

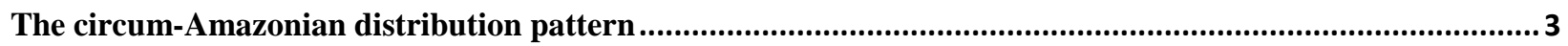

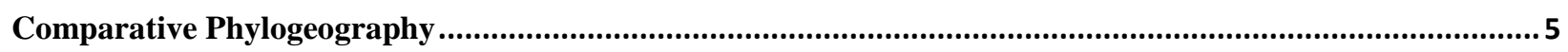

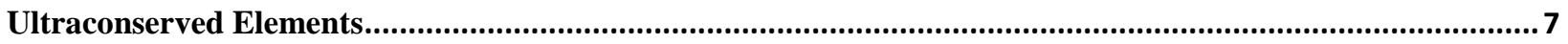

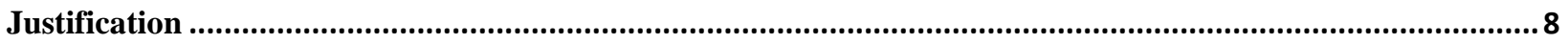

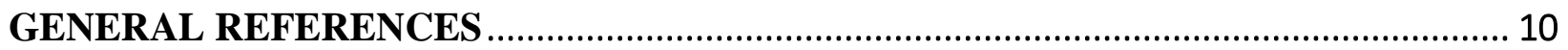

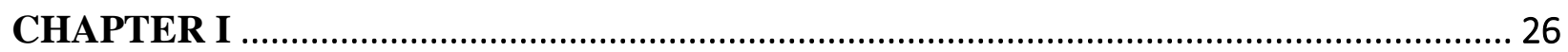

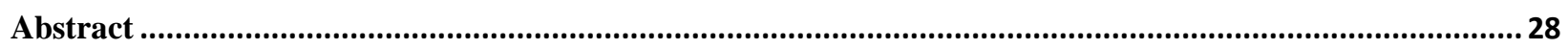

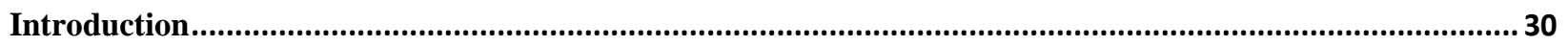

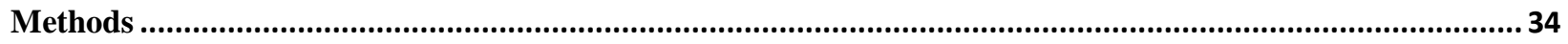

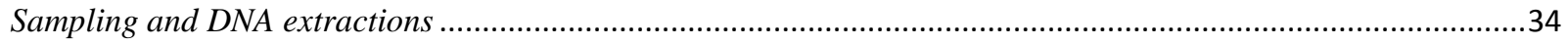

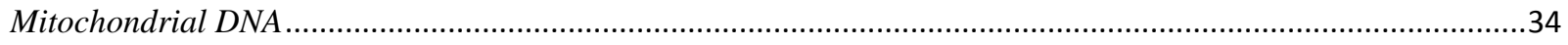

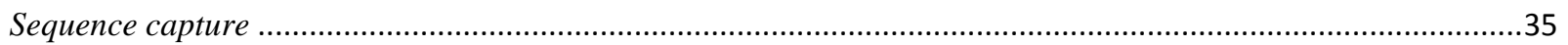

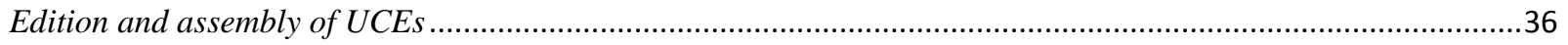

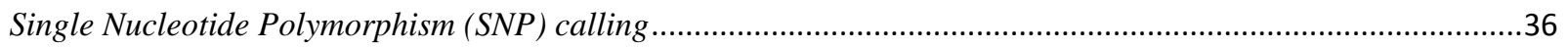

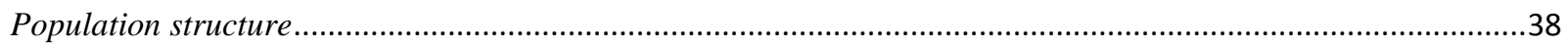

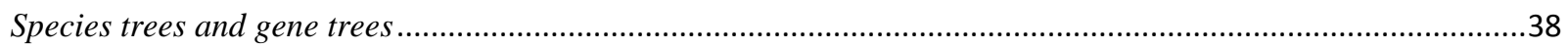

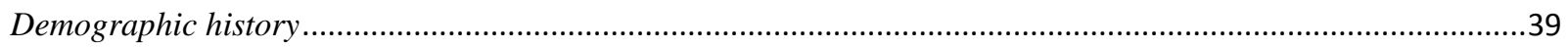

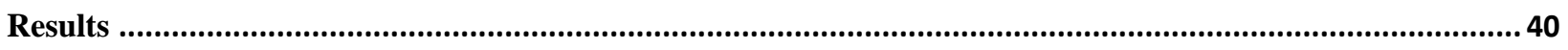

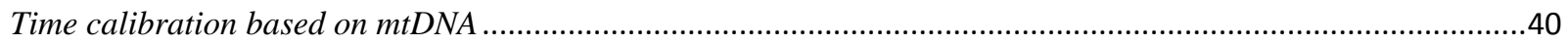

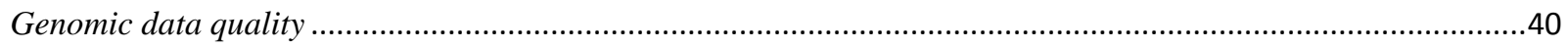

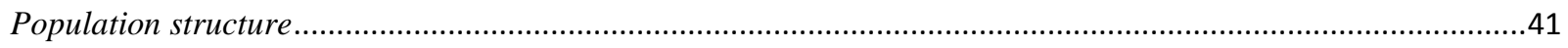

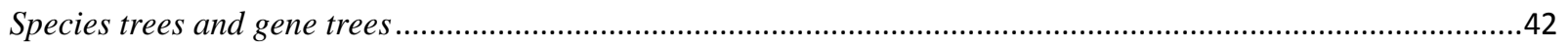

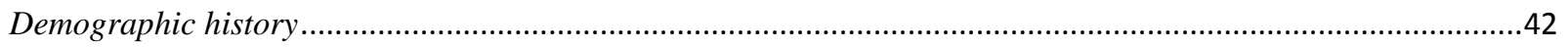

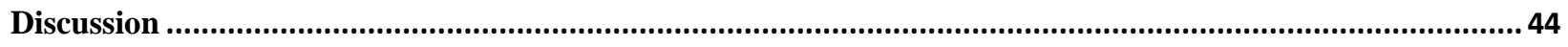

Population structure in Thamnophilus caerulescens ............................................................................44

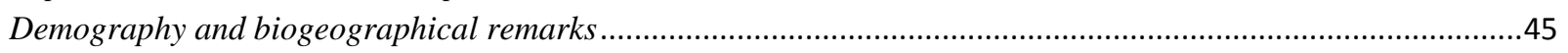

A likely scenario for the demographic history of T.caerulescens ..............................................................48

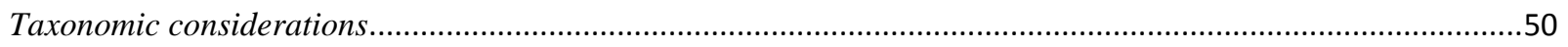

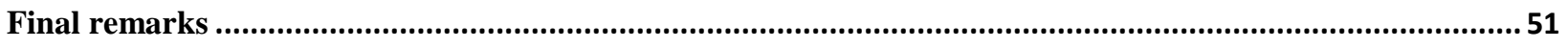

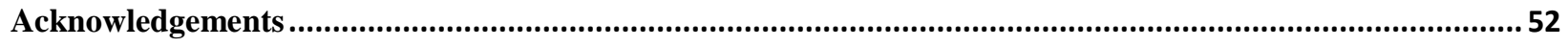




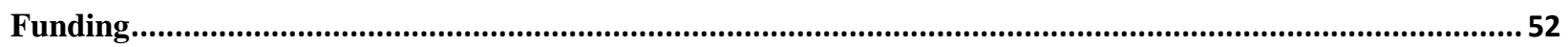

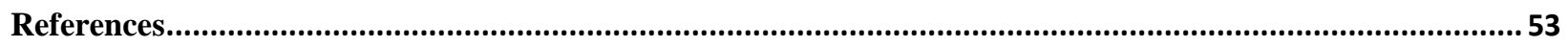

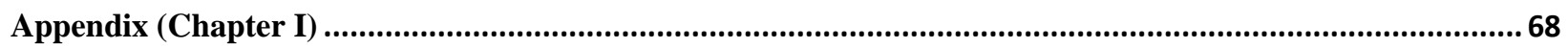

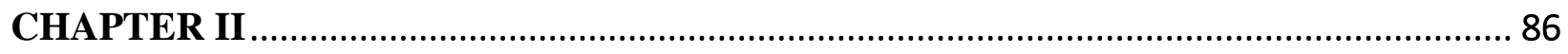

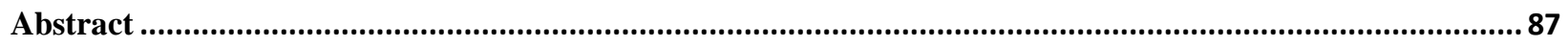

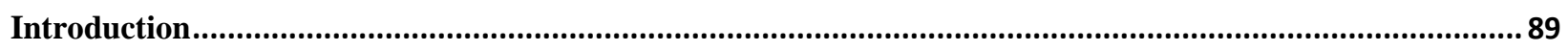

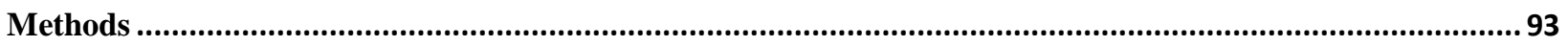

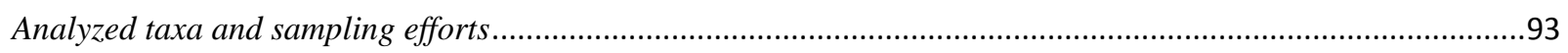

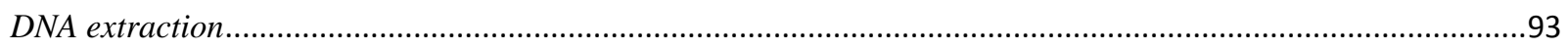

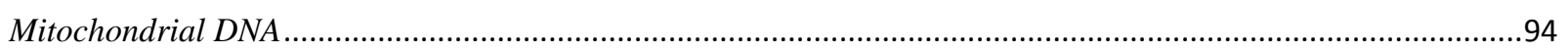

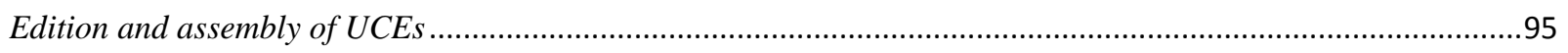

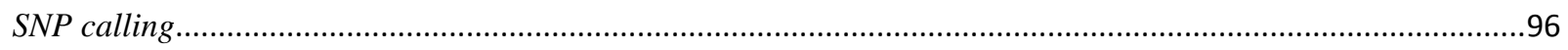

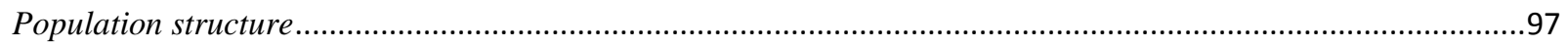

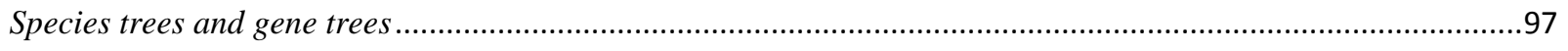

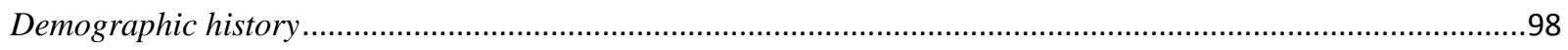

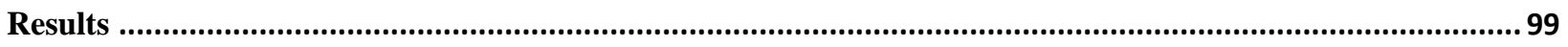

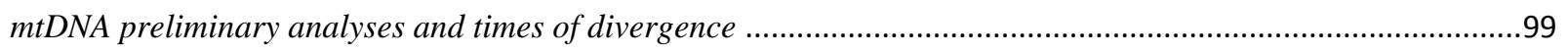

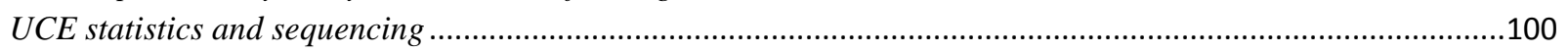

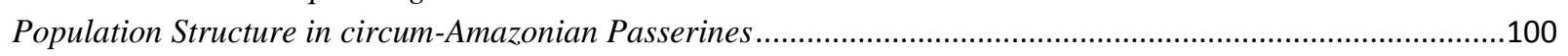

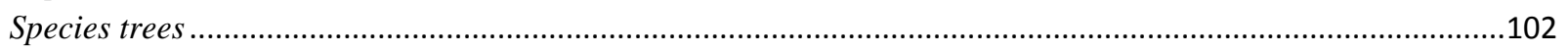

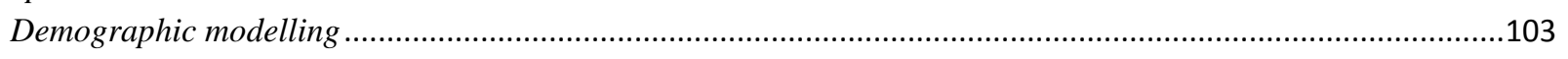

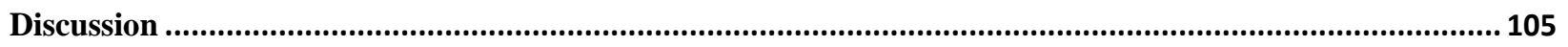

Population structure of circum-Amazonian Passerines ..............................................................................105

Species trees and phylogenetics patterns ............................................................................................. 107

Demographic modeling and the rise of the circum-Amazonian distribution....................................................108

Some taxonomic and phylogenetic considerations of circum-Amazonian Passerines .......................................111

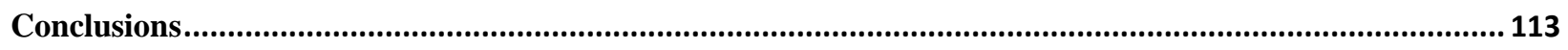

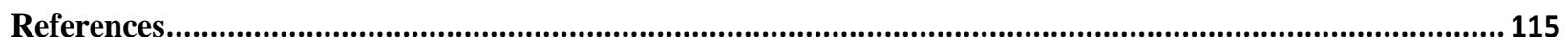

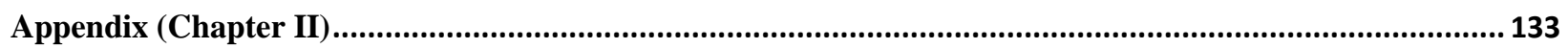




\section{General Introduction}

Neotropical biomes and ecosystems exhibit high biodiversity and a wide range of ecological/geological characteristics (Connell, 1978; Stotz et al., 1996; Myers et al., 2000; Rull, 2011; Richardson \& Pennington, 2016).

The Neotropics contains about 100,000 species of seed plants $(37 \%$ of the world's species, Antonelli \& Sanmartín, 2011), more of 3,000 species of amphibians (50\% of all amphibian richness, Young et al., 2004) and have high levels of richness in reptiles (Böhm et al., 2013). In the same way, the Neotropical areas harbor approximately 3,800 species of birds (Stotz et al., 1996) a $36 \%$ of all known landbird species and the highest level of endemicity in the world (Newton \& Dale, 2001), and probably these values are being underestimated.

Several theoretical and empirical approaches have been performed to identify and understand the processes involved in the evolution of such high diversity in the Neotropics (e.g. Sick, 1967; Haffer, 1969; Vuilleumier, 1971; Brown, 1979; Cracraft, 1985; Cracraft \& Prum, 1988; Hooghiemstra \& van der Hammen, 1998; Garzón-Orduña et al., 2014; Antonelli et al., 2018; Rull, 2018).

Mainly, these efforts have focused in the analysis of the Amazonian region. Thus, several hypotheses about the origin and maintenance of diversity of the Amazonia have been proposed (reviewed by Haffer, 1997 and Rull, 2018). Two of these hypotheses are based in the presence of rivers acting as barriers among populations/species. In the first one, the River Hypothesis (Sick, 1967; Capparella, 1988), the rise/presence of rivers in the Amazonian basin are the main cause in the separation of animal ancestral populations in this region (originally, the idea about rivers acting like barriers was outlined by Wallace, 1854). In the second one, the River-refuge Hypothesis 
(Haffer, 1993), the isolation of ancestral populations in the Amazonia was a consequence of (a) several emerging rivers and (b) "ecologically unsuitable terrain" in the northern and southern Amazonia during the dry glacial periods in the Quaternary. Also, the Paleogeography Hypothesis (Croizat, 1976), states that geological processes (tectonic movements and level sea fluctuations) influence (indirectly) the diversity/distribution of species/subspecies allowing the isolation and reconnection of Amazonian populations. Lastly, the Refugia Hypothesis proposes that the biodiversity in Amazonia was molded by a series of climatic fluctuations during the Cenozoic, producing a reduction of the Neotropical Forests (Haffer, 1969; Vanzolini \& Williams, 1970). (Cracraft, 1985) proposed other alternative to the "refugia" hypothesis; using the South American Avifauna, stated that endemism areas in these regions could be older (and, subsequently, the origin of its biodiversity) than the Pleistocene.

All these hypotheses have been subject to wide discussion, and several tests have been implemented to corroborate or refute their assumptions (Mayr \& O’Hara, 1986; Salo, 1987; Nores, 1999; Lougheed et al., 1999; Colinvaux et al., 2000; Haffer \& Prance, 2001; Haffer, 2008; FernAndes et al., 2012; Maldonado-Coelho et al., 2013; Garzón-Orduña et al., 2015; Rocha \& Kaefer, 2019, among others). For instance, Bennett et al., (2012) broadly discuss about the origin of biodiversity in Neotropics and the influence of the 'refugia' proposed by Haffer (1969), while Ramírez-Barahona \& Eguiarte (2013), Leite et al., (2016) and Arruda et al., (2017) tested the influence of climatic fluctuations during the Pleistocene in Neotropical regions. In the same way, Albert et al. (2018) review the impact of the change of course of the Amazon River in the diversification of Neotropics, and Nazareno et al. (2018) tested the importance of the riverine barriers (Wallace hypothesis) in some species of plants. Côrtes et al. and Mogni et al. (2015) tested the Pleistocene arcs as driver of diversification in the South American Seasonally Forests for some 
species of plants. Finally, in a study based on 27 avian lineages, Smith et al. (2014) propose that the high diversification of Neotropical birds was not mainly affected by the changes in the South American landscape, but also due to dispersal events creating isolation and speciation.

Because of this bias in the quantity and quality of studies about Amazonia in relation to others Neotropical regions, the information about the evolutionary and biogeographic processes acting on the non-Amazonian regions is relatively scarce. However, some theoretical and empirical approaches have been performed to identify and understand the processes involved in the biodiversity of non-Amazonian areas/taxa. Initially, multiple works covered general descriptions and classifications of the different Neotropical regions (e.g. Haffer, 1969; Cabrera \& Willink, 1980; Rivas-Martínez \& Tovar, 1983; Cracraft, 1985; Dinerstein et al., 1995; and Morrone, 2014). Others were focused in open lowlands from South America, like the Cerrado, the Caatinga and the Chaco (Prado \& Gibbs, 1993; da Silva, 1995; Bridgewater et al., 2004; Mayle, 2006; Roig-Juñent et al., 2006; and Caetano \& Naciri, 2011). In the same way, the Andean region (Fjeldså, 1992; Knapp, 2002; Doan, 2003; Brumfield \& Edwards, 2007; Ribas et al., 2007; Graham, 2009; Cadena et al., 2016; Chazot et al., 2016; Cuesta et al., 2016) and the Atlantic Forest have been studied (Damasceno et al., 2014; Amaral et al., 2016; Dalapicolla et al., 2018). Among these works, there is no consensus in the explanations about the basic evolutionary processes/patterns acting on these regions.

\section{The circum-Amazonian distribution pattern}

Despite a wide variety of proposed evolutionary and biogeographic mechanisms intended to explain Neotropical diversity, our understanding remains scarce for some of these patterns. For 
instance, a considerable number of birds are distributed in those areas surrounding Amazonia but are absent from Amazonia itself (Remsen et al., 1991; Bates, 1997; Lovette, 2004), and we have no clear understanding of the mechanisms responsible for those distributions. Such distributional pattern is known as the "circum-Amazonian distribution" (Figure 1) and is characterized by the presence of phylogenetically related groups mainly in "(a) montane forested areas on the humid slopes of the Andes and the Coastal Range of Venezuela or the Tepui region; and in (b) lowland forested areas south and east of the lowland forests of Amazonia" (Remsen et al., 1991).
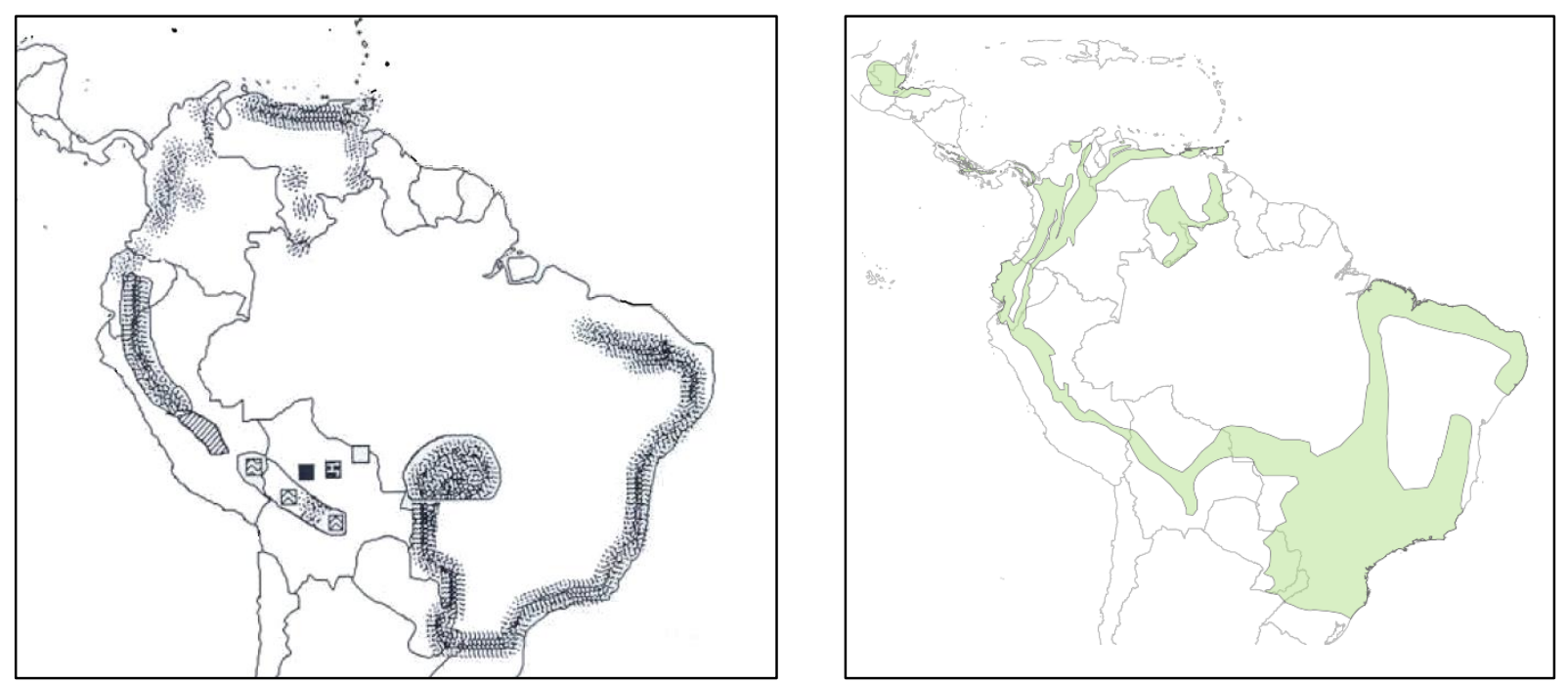

Figure 1. Circum-Amazonian distribution pattern sensu Remsen et al. (1991). Left map: Distribution of Platyrinchus mystaceus (modified from Remsen et al. (1991). Rigth map: Distribution of Dysithamnus mentalis (BirdLife International, 2016).

In the first study describing the circum-Amazonian pattern, Remsen et al. (1991) describe that species like Platyrinchus mystaceus, some Hemitriccus, Dysithamnus mentalis, Phyllomyias burmeisteri, and the Elaenia species albiceps, parvirostris, and obscura, among others, share this distributional pattern. Subsequent works have identified other taxa as circum-Amazonian. Bates (1997) stated that two species of Tiaris, T. obscura and T. fuliginosa, have a geographical 
distribution congruent with the proposed by Remsen et al. (1991). Also, populations of Phaeothlypis (Lovette, 2004); and the species Synallaxis ruficapilla and S. moesta (Batalha-Filho et al., 2013) share this pattern. Some species of genus Cercomacra (C. melanaria, C. ferdinandi, C. carbonaria, and C. nigricans complex) fit partially into this distributional pattern (see Tello et al., 2014). In a recent study, Savit \& Bates (2015) described the intraspecific genetic structure of the burnished-buff tanager (Tangara cayana), another 'circum-Amazonian' bird.

There are also examples in non-passerines such as the genus Pionus, in which the sordidusmaximiliani complex seem to exhibit complementary geographical ranges resulting in a circumAmazonian distribution (see Ribas et al., 2007). Moreover, the circum-Amazonian distribution pattern can also be found in other non-avian groups such as some insects and plants (e.g. Prado \& Gibbs, 1993; Erwin, 2000; Canals \& Johnson, 2000; Knapp, 2002; Irmler, 2009).

Nevertheless, whereas the diversity and distribution patterns in adjacent Neotropical regions have been the focus of more studies, this complex pattern of distribution has not received enough attention, and the events and evolutionary processes behind it have not been thoroughly revealed.

\section{Comparative Phylogeography}

Phylogeography is a relatively recent and successful field that, in a broad definition, aims at studying the geographical history of a particular clade using populations as terminals instead of species (see Avise et al., 1987; Zink, 2002). Phylogeography starts with the rise of mitochondrial DNA sequencing, allowing analyses to identify genealogical patterns among individuals, and link these patterns with the geographic distributions of populations (Avise, 2009). The advent of new 
mathematical and molecular tools now allows comparison of genealogical patterns (based in the estimates of gene flow/divergence among species) across different lineages/taxa ('Multi-species phylogeographic' studies) co-occurring in time and space (Hickerson et al., 2010). Such multitaxon approach is known as comparative phylogeography (Arbogast \& Kenagy, 2001) and its main objective is to search for concordant splits within contemporaneous, co-distributed species (Bermingham \& Avise, 1986). In this way, the level of "phylogeographic congruence is a measure of the historical stability of the current species assemblage" (Zink, 2002), namely, a particular evolutionary reconstruction (a hypothesis) on co-distributed species affected by similar climatic/geological events would be more 'supported' while more individuals phylogeographic patterns being congruent. This approach would be analog to some analyses in historical biogeography that use phylogenies and "area cladograms" of several groups to identify common biogeographic patterns across space (see Nelson \& Platnick, 1981; Humphries \& Parenti, 1999). Among the methodologies developed to access the level of phylogeographic congruence of codistributed taxa, the hierarchical approximate Bayesian Computational (hABC) framework proposed by Hickerson et al. (2006). This methodology allows to quantify the probability of simultaneous divergence among populations/taxa, estimating demographic parameters (e.g. across-species demographic variation, divergence times, inter-gene variability in coalescent times, DNA mutation rate heterogeneity, among others, see Hickerson et al., 2007) from multiple phylogeographic datasets (from these populations/taxa) in a single analysis. Posteriorly, this pipeline was upgraded to test evolutionary and biogeographical scenarios (e.g. dispersal/vicariance/extinctions); to include climatic, ecological and geological (palinological) data into the prior parameters of tested model(s); and, to allow the use of multi-locus DNA sequences data (see Huang et al., 2011). This method has been widely used. For instance, 
Hickerson \& Meyer (2008) implemented a hierarchical approximate Bayesian computation (hABC) to test vicariance/dispersal explanations of allopatric diversification across co-distributed cowrie gastropods (Cypraeidae, Mollusca), and Bell et al. (2011) used five species co-distributed rainforest frogs multi-locus datasets to test evidence of single/multiple vicariance events in the Australian Wet Tropics rainforests. Recently, Robinson et al. (2014) applied a hABC method to infer population history from genomic data, using as example populations of Biorhiza pallida.

\section{Ultraconserved Elements}

Initially, the empirical works in comparative phylogeography were based on the DNA information from the mitochondrial, nuclear or a few individual genes (Hickerson et al., 2006). With the advent of Massively Parallel Sequencing (MPS, Shendure \& Ji, 2008), the possibility to obtain multiple sets of sequences from genomes has increased (Edwards et al., 2015; Edwards et al., 2016).

Additionally, the use of highly conserved genomic sequences or 'ultraconserved elements' (UCEs, see Bejerano et al., 2004) allows the use of a large set of universal markers to infer relationships among lineages (Faircloth et al., 2012; Faircloth et al., 2015). UCEs are "highly conserved regions of organismal genomes shared among evolutionary distant taxa" whose function in the genome is associated with gene regulation (Pennacchio et al., 2006) and development (Sandelin et al., 2004; Woolfe et al., 2004). For any given UCE, levels of sequence variation increase as one moves away toward the flanking regions. Therefore, sequence data from this gradient of variation, allows sampling several levels of sequence diversity that reflect different evolutionary timescales (Faircloth et al., 2012). Hence, UCEs can be used with MPS protocols to generate huge numbers of orthologous sequence data among taxonomically diverse groups. In recent reviews, Heyduk et 
al. (2016) and Harvey et al. (2016) show the advantages/precautions in the use of the target enrichment methodologies, like as UCEs.

Since their application as molecular markers in phylogeny and evolution, the UCEs has been increasing recently. For instance, UCEs have proven to be useful in the reconstruction of phylogenetic relationships in Hymenoptera (Faircloth et al., 2015), in New World Sparrows (Passerellidae, Bryson Jr. et al., 2016), phylogeny and genetic relationships in the salamander

Plethodon serratus (Newman \& Austin, 2016). Also, the estimation of demographic and population parameters based on UCE data has been shown to improve relative to those based on mtDNA or other genomic markers (Smith et al., 2013; Harvey et al., 2013; Zarza et al., 2016; Myers et al., 2019).

\section{Justification}

Here, I implemented a comparative phylogeographic approach to study the evolutionary history of a number of passerine birds with circum-Amazonian distribution using genomic data (UCEs). First, I tested whether these circum-Amazonian distributions are the result of a congruent history across taxa or whether it is the result of lineage-specific histories. Also was possible test whether congruent topologies are associated to dispersal and vicariance events, which allow me to do inferences on the various proposed hypotheses for Neotropical diversity (e.g. paleogeography, refugia and riverine hypotheses). Additionally, it was possible to estimate the level of influence of the environmental variables on the species of these regions, and the constraints imposed by these factors. Furthermore, the genealogical/evolutionary information of each lineage was useful to determine levels of demographic structure and the dynamics among isolated populations from the 
same lineages (e.g. migration rates, speciation), which generated information on the role of lineage-specific histories and idiosyncrasies in shaping circum-Amazonian populations. 


\section{General references}

Albert, J. S., Val, P., \& Hoorn, C. (2018). The changing course of the Amazon River in the Neogene: center stage for Neotropical diversification. Neotropical Ichthyology, 16(3), e180033.

Antonelli, A. \& Sanmartín, I. (2011). Why are there so many plant species in the Neotropics? TAXON, 60(2), 403-414.

Antonelli, A., Zizka, A., Carvalho, F. A., Scharn, R., Bacon, C. D., Silvestro, D., \& Condamine, F. L. (2018). Amazonia is the primary source of Neotropical biodiversity. Proceedings of the National Academy of Sciences, 115(23), 6034-6039.

Arbogast, B. S. \& Kenagy, G. J. (2001). Comparative phylogeography as an integrative approach to historical biogeography. Journal of Biogeography, 28, 819-825.

Arruda, D. M., Schaefer, C. E. G. R., Fonseca, R. S., Solar, R. R. C., \& FernAndes-Filho, E. I. (2018). Vegetation cover of Brazil in the last $21 \mathrm{ka}$ : New insights into the Amazonian refugia and Pleistocenic Arc Hypotheses. Global Ecology and Biogeography, 27, 47-56.

Avise, J. C. (2009). Phylogeography: retrospect and prospect. Journal of Biogeography, 36, 3-15.

Avise, J. C., Arnold, J., Ball, R. M., Bermingham, E., Lamb, T., Neigel, J. E., Reeb, C. A., \& Saunders, N. C. (1987). Intraspecific phylogeography: The mitochondrial DNA bridge between population genetics and systematics. Annual Review of Ecology and Systematics, 18, 489-522.

Batalha-Filho, H., Irestedt, M., Fjeldså, J., Ericson, P. G. P., Silveira, L. F., \& Miyaki, C. Y. (2013). Molecular systematics and evolution of the Synallaxis ruficapilla complex (Aves: Furnariidae) in the Atlantic Forest. Molecular Phylogenetics and Evolution, 67, 86-94. 
Bates, J. M. (1997). Distribution and geographic variation in three South American grassquits (Emberizinae, Tiaris). Ornithological Monographs, 48, 91-110.

Bejerano, G., Pheasant, M., Makunin, I., Stephen, S., Kent, W. J., Mattick, J. S., \& Haussler, D. (2004). Ultraconserved elements in the human genome. Science, 304, 1321-1325.

Bell, R. C., MacKenzie, J. B., Hickerson, M. J., Chavarría, K. L., Cunningham, M., Williams, S., \& Moritz, C. (2011). Comparative multi-locus phylogeography confirms multiple vicariance events in co-distributed rainforest frogs. Proceedings of the Royal Society of London B: Biological Sciences, 279(1730), 991-999.

Bennett, K. D., Bhagwat, S. A., \& Willis, K. J. (2012). Neotropical refugia. The Holocene, 22(1), $1207-1214$.

Bermingham, E. \& Avise, J. C. (1986). Molecular zoogeography of freshwater fishes in the southeastern United States. Genetics, 113, 939-965.

BirdLife International (2016). Species factsheet: Dysithamnus mentalis. downloaded from: http://www.birdlife.org on 28/11/2016.

Böhm, M., Collen, B., Baillie, J. E., Bowles, P., Chanson, J., Cox, N., Hammerson, G., Hoffmann, M., Livingstone, S. R., Ram, M., Rhodin, A. G., Stuart, S. N., van Dijk, P. P., Young, B. E., Afuang, L. E., Aghasyan, A., García, A., Aguilar, C., Ajtic, R., Akarsu, F., Alencar, L. R., Allison, A., Ananjeva, N., Anderson, S., Andrén, C., Ariano-Sánchez, D., Arredondo, J. C., Auliya, M., Austin, C. C., Avci, A., Baker, P. J., Barreto-Lima, A. F., Barrio-Amorós, C. L., Basu, D., Bates, M. F., Batistella, A., Bauer, A., Bennett, D., Böhme, W., Broadley, D., Brown, R., Burgess, J., Captain, A., Carreira, S., del Rosario Castañeda, M., Castro, F., Catenazzi, A., Cedeño-Vázquez, J. R., Chapple, D. G., Cheylan, M., Cisneros-Heredia, D. F., Cogalniceanu, D., Cogger, H., Corti, 
C., Costa, G. C., Couper, P. J., Courtney, T., Crnobrnja-Isailovic, J., Crochet, P.-A., Crother, B., Cruz, F., Daltry, J. C., Daniels, R. R., Das, I., de Silva, A., Diesmos, A. C., Dirksen, L., Doan, T. M., Dodd, C. K., Doody, J. S., Dorcas, M. E., de Barros Filho, J. D., Egan, V. T., Mouden, E. H. E., Embert, D., Espinoza, R. E., Fallabrino, A., Feng, X., Feng, Z.-J., Fitzgerald, L., FloresVillela, O., França, F. G., Frost, D., Gadsden, H., Gamble, T., Ganesh, S., Garcia, M. A., GarcíaPérez, J. E., Gatus, J., Gaulke, M., Geniez, P., Georges, A., Gerlach, J., Goldberg, S., Gonzalez, J.-C. T., Gower, D. J., Grant, T., Greenbaum, E., Grieco, C., Guo, P., Hamilton, A. M., Hare, K., Hedges, S. B., Heideman, N., Hilton-Taylor, C., Hitchmough, R., Hollingsworth, B., Hutchinson, M., Ineich, I., Iverson, J., Jaksic, F. M., Jenkins, R., Joger, U., Jose, R., Kaska, Y., Kaya, U., Keogh, J. S., Köhler, G., Kuchling, G., Kumlutas, Y., Kwet, A., Marca, E. L., Lamar, W., Lane, A., Lardner, B., Latta, C., Latta, G., Lau, M., Lavin, P., Lawson, D., LeBreton, M., Lehr, E., Limpus, D., Lipczynski, N., Lobo, A. S., López-Luna, M. A., Luiselli, L., Lukoschek, V., Lundberg, M., Lymberakis, P., Macey, R., Magnusson, W. E., Mahler, D. L., Malhotra, A., Mariaux, J., Maritz, B., Marques, O. A., Márquez, R., Martins, M., Masterson, G., Mateo, J. A., Mathew, R., Mathews, N., Mayer, G., McCranie, J. R., Measey, G. J., Mendoza-Quijano, F., Menegon, M., Métrailler, S., Milton, D. A., Montgomery, C., Morato, S. A., Mott, T., MuñozAlonso, A., Murphy, J., Nguyen, T. Q., Nilson, G., Nogueira, C., Núñez, H., Orlov, N., Ota, H., Ottenwalder, J., Papenfuss, T., Pasachnik, S., Passos, P., Pauwels, O. S., Pérez-Buitrago, N., PérezMellado, V., Pianka, E. R., Pleguezuelos, J., Pollock, C., Ponce-Campos, P., Powell, R., Pupin, F., Díaz, G. E. Q., Radder, R., Ramer, J., Rasmussen, A. R., Raxworthy, C., Reynolds, R., Richman, N., Rico, E. L., Riservato, E., Rivas, G., da Rocha, P. L., Rödel, M.-O., Schettino, L. R., Roosenburg, W. M., Ross, J. P., Sadek, R., Sanders, K., Santos-Barrera, G., Schleich, H. H., Schmidt, B. R., Schmitz, A., Sharifi, M., Shea, G., Shi, H.-T., Shine, R., Sindaco, R., Slimani, T., 
Somaweera, R., Spawls, S., Stafford, P., Stuebing, R., Sweet, S., Sy, E., Temple, H. J., Tognelli, M. F., Tolley, K., Tolson, P. J., Tuniyev, B., Tuniyev, S., Üzüm, N., van Buurt, G., Sluys, M. V., Velasco, A., Vences, M., Veselý, M., Vinke, S., Vinke, T., Vogel, G., Vogrin, M., Vogt, R. C., Wearn, O. R., Werner, Y. L., Whiting, M. J., Wiewandt, T., Wilkinson, J., Wilson, B., Wren, S., Zamin, T., Zhou, K., \& Zug, G. (2013). The conservation status of the world's reptiles. Biological Conservation, 157, $372-385$.

Bridgewater, S., Ratter, J. A., \& Ribeiro, J. F. (2004). Biogeographic patterns, b-diversity and dominance in the Cerrado biome of Brazil. Biodiversity and Conservation, 13, 2295-2318.

Brown, K. S. (1979). Ecologia Geográfica e Evolução nas Florestas Neotropicais. Universidade Estadual de Campinas.

Brumfield, R. T. \& Edwards, S. V. (2007). Evolution into and out of the Andes: A bayesian analysis of historical diversification in Thamnophilus antshrikes. Evolution, 61, 346-367.

Bryson Jr., R. W., Faircloth, B. C., Tsai, W. L. E., McCormack, J. E., \& Klicka, J. (2016). Target enrichment of thousands of ultraconserved elements sheds new light on early relationships within New World Sparrows (Aves: Passerellidae). The Auk, 133, 451-458.

Cabrera, A. \& Willink, A. (1980). Biogeografía de América Latina. O.E.A.

Cadena, C. D., Pedraza, C. A., \& Brumfield, R. T. (2016). Climate, habitat associations and the potential distributions of Neotropical birds: Implications for diversification across the Andes. Revista de la Academia Colombiana de Ciencias Exactas, Físicas y Naturales, 40(155), 275-287. 
Caetano, S. \& Naciri, Y. (2011). The Biogeography of Seasonally Dry Tropical Forests in South America. In Seasonally Dry Tropical Forests: Ecology and Conservation, chapter 2, (pp. 23-44). Island Press.

Canals, G. \& Johnson, K. (2000). A new species of Angulopis (Lycaenidae, Eumaeini) from relict coastal forest in east-central Argentina. The taxonomic report of the International Lepidoptera Survey, 2(3), 1-5.

Capparella, A. (1988). Genetic variation in Neotropical birds: implication for the speciation process. Acta XIX Congr. Intern. Ornith., 2, 1658-1664.

Chazot, N., Willmott, K. R., Condamine, F. L., De-silva, D. L., Freitas, A. V. L., Lamas, G., Morlon, H., Giraldo, C. E., Jiggins, C. D., Joron, M., Mallet, J., Uribe, S., \& Elias, M. (2016). Into the Andes: multiple independent colonizations drive montane diversity in the Neotropical clearwing butterflies Godyridina. Molecular Ecology.

Colinvaux, P. A., Oliveira, P. E. D., \& Bush, M. B. (2000). Amazonian and Neotropical plant communities on glacial time-scales: The failure of the aridity and refuge hypotheses. Quaternary Science Reviews, 19, 141-169.

Connell, J. H. (1978). Diversity in tropical rain forest and costal reefs. Science, 199(4335), 13021310.

Côrtes, A. L. A., Rapini, A., \& Daniel, T. F. (2015). The Tetramerium lineage (Acanthaceae: Justicieae) does not support the Pleistocene Arc Hypothesis for South American Seasonally Dry Forests. American Journal of Botany, 102(6), 1-16. 
Cracraft, J. (1985). Historical biogeography and patterns of differentiation within the South American avifauna: areas of endemism. Ornithological Monographs, 36, 49-84.

Cracraft, J. \& Prum, R. O. (1988). Patterns and process of diversification: Speciation and historical congruence in some Neotropical birds. Evolution, 42, 603-620.

Croizat, L. (1976). Biogeografía analítica y sintética ('Panbiogeografía') de las américas. Biblioteca de la Academia de Ciencias Físicas, Matemáticas y Naturales, 35, 1-890.

Cuesta, F., Muriel, P., Llambí, L. D., Halloy, S., Aguirre, N., Beck, S., Carilla, J., Meneses, R. I., Cuello, S., Grau, A., Gámez, L. E., Irazábal, J., Jácome, J., Jaramillo, R., Ramírez, L., Samaniego, N., Suárez-Duque, D., Thompson, N., Tupayachi, A., nas, P. V., Yager, K., Becerra, M. T., Pauli, H., \& Gosling, W. D. (2016). Latitudinal and altitudinal patterns of plant community diversity on mountain summits across the tropical Andes. Ecography, 40, 1381-1394.

Dalapicolla, J., Leite, Y. L. R., \& Calafell, F. (2018). Historical connections among river basins and climatic changes explain the biogeographic history of a water rat. PeerJ, 6, e5333.

Damasceno, R., Strangas, M. L., Carnaval, A. C., Rodrigues, M. T., \& Moritz, C. (2014). Revisiting the vanishing refuge model of diversification. Frontiers in Genetics, 5, 353.

da Silva, J. M. C. (1995). Biogeographical analysis of the South American Cerrado avifauna. Steenstrupia, 21, 49-67.

Dinerstein, E., Olson, D. M., Graham, D. J., Webster, A. L., Primm, S. A., Bokkbinder, M. P., \& Ledec, G. (1995). A Conservation Assessment of the Terrestrial Ecoregions of Latin America and the Caribbean. The World Bank Washington, D.C. 
Doan, T. M. (2003). A south-to-north biogeographic hypothesis for Andean speciation: evidence from the lizard genus Proctoporus (Reptilia, Gymnophthalmidae). Journal of Biogeography, 30, $361-374$.

Edwards, S. V., Potter, S., Schmitt, C. J., Bragg, J. G., \& Moritz, C. (2016). Reticulation, divergence, and the phylogeography-phylogenetics continuum. Proceedings of the National Academy of Sciences of the United States of America, 113(29), 8025-8032.

Edwards, S. V., Shultz, A. J., \& Campbell-Staton, S. C. (2015). Next-generation sequencing and the expanding domain of phylogeography. Folia Zoologica, 64(3), 187-206.

Erwin, T. L. (2000). Arboreal beetles of Neotropical forests: Taxonomic supplement for the Agra virgata and ohausi groups with a new species and additional distribution records (Coleoptera: Carabidae). The Coleopterists Bulletin, 54(2), 251-262.

Faircloth, B. C., Branstetter, M. G., White, N. D., \& Brady, S. G. (2015). Target enrichment of ultraconserved elements from arthropods provides a genomic perspective on relationships among hymenoptera. Molecular Ecology Resources, 15, 489-501.

Faircloth, B. C., Mccormack, J. E., Crawford, N. G., Harvey, M. G., Brumfield, R. T., \& Glenn, T. C. (2012). Ultraconserved elements anchor thousands of genetic markers spanning multiple evolutionary timescales. Systematic Biology, 61(5), 717-726.

FernAndes, A. M., Wink, M., \& Aleixo, A. (2012). Phylogeography of the chestnut-tailed antbird (Myrmeciza hemimelaena) clarifies the role of rivers in Amazonian biogeography. Journal of Biogeography, 39, 1524-1535. 
Fjeldså, J. (1992). Biogeographic pattern and evolution of the avifauna of relict high-altitude woodlands of the Andes. Steenstrupia, 18, 9-62.

Garzón-Orduña, I. J., Benetti-Longhini, J. E., \& Brower, A. V. Z. (2014). Timing the diversification of the Amazonian biota: butterfly divergences are consistent with Pleistocene refugia. Journal of Biogeography, 41, 1631-1638.

Garzón-Orduña, I. J., Benetti-Longhini, J. E., \& Brower, A. V. Z. (2015). Competing paradigms of Amazonian diversification and the Pleistocene refugium hypothesis. Journal of Biogeography, $42,1349-1363$.

Graham, A. (2009). The Andes: a geological overview from a biological perspective. Annals of the Missouri Botanical Garden, 96(3), 371-385.

Haffer, J. (1969). Speciation in Amazonian forest birds. Science, New Series, 165, 131-137.

Haffer, J. (1993). On the 'river effect' in some forest birds of southern Amazonia. Boletim do Museu Paraense Emilio Goeldi Serie Zoologia, 8(1), 217-245.

Haffer, J. (1997). Alternative models of vertebrate speciation in Amazonia: an overview. Biodiversity and Conservation, 6, 451-476.

Haffer, J. (2008). Hypotheses to explain the origin of species in Amazonia. Brazilian Journal of Biology, 68(4), 917-947.

Haffer, J. \& Prance, G. (2001). Climatic forcing of evolution in Amazonia during the Cenozoic: on the refuge theory of biotic differentiation. Amazoniana, 16, 579-607. 
Harvey, M. G., Smith, B. T., Glenn, T. C., Faircloth, B. C., \& Brumfield, R. T. (2013). Sequence capture versus restriction sites associated DNA sequencing for phylogeography. arXiv preprint arXiv:1312.6439.

Harvey, M. G., Smith, B. T., Glenn, T. C., Faircloth, B. C., \& Brumfield, R. T. (2016). Sequence capture versus restriction site associated DNA sequencing for shallow systematics. Systematic Biology, 65(5), 910-924.

Heyduk, K., Stephens, J. D., Faircloth, B. C., \& Glenn, T. C. (2016). Targeted DNA Region Resequencing. In Field Guidelines for Genetic Experimental Designs in High-Throughput Sequencing, chapter 3, (pp. 43-68). Springer International Publishing Switzerland.

Hickerson, M. J., Carstens, B., Cavender-Bares, J., Crandall, K., Graham, C., Johnson, J., Rissler, L., Victoriano, P., \& Yoder, A. (2010). Phylogeography's past, present, and future: 10 years after Avise, 2000. Molecular Phylogenetics and Evolution, 54, 291-301.

Hickerson, M. J. \& Meyer, C. P. (2008). Testing comparative phylogeographic models of marine vicariance and dispersal using a hierarchical bayesian approach. BMC Evolutionary Biology, 8, 322.

Hickerson, M. J., Stahl, E., \& Takebayashi, N. (2007). msbayes: Pipeline for testing comparative phylogeographic histories using hierarchical approximate bayesian computation. BMC Bioinformatics, 8, 268.

Hickerson, M. J., Stahl, E. A., \& Lessios, H. A. (2006). Test for simultaneous divergence using approximate bayesian computation. Evolution, 60(12), 2435-2453. 
Hooghiemstra, H. \& van der Hammen, T. (1998). Neogene and Quaternary development of the Neotropical rain forest: the forest refugia hypothesis, and a literature overview. Earth-Science Reviews, 44, 147-183.

Huang, W., Takebayashi, N., Qi, Y., \& Hickerson, M. J. (2011). Mtml-msbayes: Approximate bayesian comparative phylogeographic inference from multiple taxa and multiple loci with rate heterogeneity. BMC Bioinformatics, 12(1), 1.

Humphries, C. \& Parenti, L. (1999). Cladistic Biogeography. Oxford University Press, 2nd ed edition.

Irmler, U. (2009). New species and records of the genus Lispinus with a key to the species from Peru (Coleoptera: Staphylinidae: Osoriinae). Zootaxa, 2263, 42-58.

Knapp, S. (2002). Assessing patterns of plant endemism in Neotropical uplands. The Botanical Review, 68(1), 22-37.

Leite, Y. L. R., Costa, L. P., Loss, A. C., Rocha, R. G., Batalha-Filho, H., Bastos, A. C., Quaresma, V. S., Fagundes, V., Paresque, R., Passamani, M., \& Pardini, R. (2016). Neotropical forest expansion during the last glacial period challenges Refuge Hypothesis. Proceedings of the National Academy of Sciences, 113(4), 1008-1013.

Lougheed, S. C., Gascon, C., Jones, D. A., Bogart, J. P., \& Boag, P. T. (1999). Ridges and rivers: a test of competing hypotheses of Amazonian diversification using a dart-poison frog (Epipedobates femoralis). Proceedings of the Royal Society of London B: Biological Sciences, 266(1431), 1829-1835. 
Lovette, I. J. (2004). Molecular phylogeny and plumage signal evolution in a Trans Andean and circum Amazonian avian species complex. Molecular Phylogenetics and Evolution, 32, 512-523.

Maldonado-Coelho, M., Blake, J. G., Silveira, L. F., Batalha-filho, H., \& Ricklefs, R. E. (2013). Rivers, refuges and population divergence of fire-eye antbirds (Pyriglena) in the amazon basin. Journal of Evolutionary Biology, 26, 1090-1107.

Mayle, F. E. (2006). The Late Quaternary Biogeographical History of South American Seasonally Dry Tropical Forests: Insights from Palaeo-Ecological Data. In Neotropical Savannas and Seasonally Dry Forests: Plant Diversity, Biogeography and Conservation, chapter 17, (pp. 395416). CRC Press.

Mayr, E. \& O’Hara, R. J. (1986). The biogeographic evidence supporting the Pleistocene forest refuge hypothesis. Evolution, 40(1), 55-67.

Mogni, V. Y., Oakley, L. J., \& Prado, D. E. (2015). The distribution of woody legumes in Neotropical Dry Forests: the Pleistocene Arc Theory 20 years on*. Edinburgh Journal of Botany, 72(1), 35-60.

Morrone, J. J. (2014). Biogeographical regionalization of the Neotropical region. Zootaxa, 3782(1), 001-110.

Myers, N., Mittermeier, R. A., Mittermeier, C. G., da Fonseca, G. A. B., \& Kent, J. (2000). Biodiversity hotspots for conservation priorities. Nature, 403, 853-858.

Myers, E. A., Bryson, R. W., Hansen, R. W., Aardema, M. L., Lazcano, D., \& Burbrink, F. T. (2019). Exploring Chihuahuan desert diversification in the gray-banded kingsnake, Lampropeltis alterna (Serpentes: Colubridae). Molecular Phylogenetics and Evolution, 131, 211-218. 
Nazareno, A. G., Dick, C. W., \& Lohmann, L. G. (2018). Tangled banks: a landscape genomic evaluation of Wallace's Riverine Barrier Hypothesis for three Amazon plant species. Molecular Ecology, 28(5), 980-997

Nelson, G. J. \& Platnick, N. I. (1981). Systematics and Biogeography: Cladistics and Vicariance. Columbia University Press, New York.

Newman, C. E. \& Austin, C. C. (2016). Sequence capture and next-generation sequencing of ultraconserved elements in a largegenome salamander. Molecular Ecology, 25(24), 6162-6174.

Newton, I. \& Dale, L. (2001). A comparative analysis of the avifaunas of different zoogeographical regions. Journal of Zoology, 254(2), 207-218.

Nores, M. (1999). An alternative hypothesis for the origin of Amazonian bird diversity. Journal of Biogeography, 26, 475-485.

Pennacchio, L. A., Ahituv, N., Moses, A. M., Prabhakar, S., Nobrega, M. A., Shoukry, M., Minovitsky, S., Dubchak, I., Holt, A., Lewis, K. D., Plajzer-Frick, I., Akiyama, J., Val, S. D., Afzal, V., Black, B. L., Couronne, O., Eisen, M. B., Visel, A., \& Rubin, E. M. (2006). In vivo enhancer analysis of human conserved non-coding sequences. Nature, 444, 499-502.

Prado, D. E. \& Gibbs, P. E. (1993). Patterns of species distributions in the dry seasonal forests of South America. Annals of the Missouri Botanical Garden, 80, 902-927.

Ramírez-Barahona, S. \& Eguiarte, L. E. (2013). The role of glacial cycles in promoting genetic diversity in the Neotropics: the case of cloud forests during the last glacial maximum. Ecology and Evolution, 3(3), 725-738. 
Raposo do Amaral, F., Edwards, S. V., Pie, M. R., Jennings, W. B., Svensson-Coelho, M., d'Horta, F. M., Schmitt, C. J., \& Maldonado-Coelho, M. (2016). The 'Atlantic Forest Hypothesis' does not explain Atlantic Forest phylogeography. Proceedings of the National Academy of Sciences of the United States of America, 113(15), 2097-2098.

Remsen Jr., J. V., 0., O. R., Schmitt, C. G., \& Schmitt, D. C. (1991). Zoogeography and geographic variation of Platyrinchus mystaceus in Bolivia and Peru, and the Circum-Amazonian distribution pattern. Ornitologia Neotropical, 2, 77-83.

Ribas, C. C., Moyle, R. G., Miyaki, C. Y., \& Cracraft, J. (2007). The assembly of montane biotas: linking Andean tectonics and climatic oscillations to independent regimes of diversification in pionus parrots. Proceedings of the Royal Society of London B: Biological Sciences, 274, 23992408.

Richardson, J. E. \& Pennington, R. T. (2016). Editorial: Origin of tropical diversity: From clades to communities. Frontiers in Genetics, 7, 186.

Rivas-Martínez, S. \& Tovar, O. (1983). Síntesis biogeográfica de los Andes. Collectanea Botanica, 14, 515-521.

Robinson, J. D., Bunnefeld, L., Hearn, J., Stone, G. N., \& Hickerson, M. J. (2014). Abc inference of multi-population divergence with admixture from unphased population genomic data. Molecular Ecology, 23, 4458-4471.

Rocha, D. G. d. \& Kaefer, I. L. (2019). What has become of the refugia hypothesis to explain biological diversity in Amazonia? Ecology and Evolution, 9(7), 4302-4309. 
Roig-Juñent, S., Domínguez, M., Flores, G., \& Mattoni, C. (2006). Biogeographic history of South American arid lands: A view from its arthropods using TASS analysis. Journal of Arid Environments, 66, 404-420.

Rull, V. (2011). Neotropical biodiversity: timing and potential drivers. Trends in Ecology and Evolution, 26(10), 508-513.

Rull, V. (2018). Neotropical diversification: historical overview and conceptual insights. PeerJ Preprints, 6, e27294v1.

Salo, J. (1987). Pleistocene forest refuges in the amazon: evaluation of the biostratigraphical, lithostratigraphical and geomorphological data. Annales Zoologici Fennici, 24(3), 203-211.

Sandelin, A., Bailey, P., Bruce, S., Engstrom, P. G., Klos, J. M., Wasserman, W. W., Ericson, J., \& Lenhard, B. (2004). Arrays of ultraconserved non-coding regions span the loci of key developmental genes in vertebrate genomes. BMC Genomics, 5(99), 1-9.

Savit, A. Z. \& Bates, J. M. (2015). Right around the amazon: the origin of the Circum-Amazonian distribution in Tangara cayana. Folia Zoologica, 64(3), 273-283.

Shendure, J. \& Ji, H. (2008). Next-generation DNA sequencing. Nature Biotechnology, 26(10), $1135-1145$.

Sick, H. (1967). Rios e enchentes na Amazônia como obstáculo para a avifauna. Atas Simp. Sobre a Biota Amazonica, 5, 495-520.

Smith, B. T., McCormack, J. E., Cuervo, A. M., Hickerson, M. J., Aleixo, A., Cadena, C. D., Pérez-Emán, J., Burney, C. W., Xie, X., Harvey, M. G., Faircloth, B. C., Glenn, T. C., Derryberry, 
E. P., Prejean, J., Fields, S., \& Brumfield, R. T. (2014b). The drivers of tropical speciation. Nature, $515,406-409$.

Smith, B. T., Ribas, C. C., Whitney, B. M., nos, B. E. H.-B., \& Klicka, J. (2013). Identifying biases at different spatial and temporal scales of diversification: a case study in the Neotropical parrotlet genus Forpus. Molecular Ecology, 22, 483-494.

Stotz, D. F., Fitzpatrick, J. W., Parker, T. A. I., \& Moskovits, D. K. (1996). Neotropical birds: Ecology and Conservation. University of Chicago Press.

Tello, J. G., Raposo, M., Bates, J. M., Bravo, G. A., Cadena, C. D., \& Maldonado-Coelho, M. (2014). Reassessment of the systematics of the widespread Neotropical genus Cercomacra (Aves: Thamnophilidae). Zoological Journal of the Linnean Society, 170, 546-565.

Vanzolini, P. \& Williams, E. E. (1970). South American anoles: The geographic differentiation and evolution of the anolis Chrysolepis species group (Sauria, Iguanidae), volume 19 of Arquivos de zoologia. Museu de Zoologia.

Vuilleumier, B. S. (1971). Pleistocene changes in the fauna and flora of South America. Science, New Series, 173(3999), 771-780.

Wallace, A. R. (1854). On the monkeys of the amazon. Annals and Magazine of Natural History, 14(84), 451-454.

Woolfe, A., Goodson, M., Goode, D. K., Snell, P., McEwen, G. K., Vavouri, T., Smith, S. F., North, P., Callaway, H., Kelly, K., Walter, K., Abnizova, I., Gilks, W., Edwards, Y. J. K., Cooke, J. E., \& Elgar, G. (2004). Highly conserved non-coding sequences are associated with vertebrate development. PLoS Biology, 3(1), e7. 
Young, B. E., Stuart, S. N., Chanson, J., Cox, N. A. and Boucher, T. M. (2004). Joyas que están desapareciendo: el estado de los anfibios en el Nuevo Mundo. NatureServe, Arlington, Virginia, $53 \mathrm{p}$.

Zarza, E., Faircloth, B. C., Tsai, W. L., Jr., R. W. B., Klicka, J., \& nd John E. Mccormack (2016). Hidden histories of gene flow in highland birds revealed with genomic markers. Molecular Ecology, 25(20), 5144-5157.

Zink, R. M. (2002). Methods in comparative phylogeography, and their application to studying evolution in the North American aridlands. Integrative \& Comparative Biology, 42, 953-959. 


\title{
Chapter I
}

Out of northeastern Brazil: demographic and evolutionary history

of the Variable Antshrike, Thamnophilus caerulescens (Aves,

\author{
Thamnophilidae)
}


Out of northeastern Brazil: demographic and evolutionary history of the Variable Antshrike, Thamnophilus caerulescens (Aves, Thamnophilidae)

Authors: Sergio D. Bolívar-Leguizamón ${ }^{1}$, Luís F. Silveira ${ }^{1}$, Elizabeth P. Derryberry ${ }^{2}$, Robb T. Brumfield $^{3,4}$, Gustavo A. Bravo $0^{5,6, *}$

${ }^{1}$ Museu de Zoologia da Universidade de São Paulo, 04263-000 Ipiranga, São Paulo, SP, Brazil.

${ }^{2}$ Department of Ecology and Evolutionary Biology, University of Tennessee, Knoxville, TN 37996, USA.

${ }^{3}$ Department of Biological Sciences, Louisiana State University, Baton Rouge, LA 70803, USA.

${ }^{4}$ Museum of Natural Science, Louisiana State University, Baton Rouge, LA 70803, USA.

${ }^{5}$ Department of Organismic and Evolutionary Biology, Harvard University, Cambridge, MA 02138, USA.

${ }^{6}$ Museum of Comparative Zoology, Harvard University, Cambridge, MA 02138, USA. $*$ Corresponding author $=$ 


\section{Abstract}

The Neotropics exhibit a wealth of distributional patterns that are often shared by a number of codistributed species. A distinctive pattern is the so-called "circum-Amazonian distribution", which is observed in species that do not occur in Amazonia but rather in forested habitats around it forming a continuous belt that extends south and east of Amazonia, the Andean foothills, and often into the Venezuelan Coastal Range and the Tepuis. Although this pattern is widespread across a wealth of animals and plants, the historical and biogeographic mechanisms giving rise to it remain poorly understood. The Variable Antshrike (Thamnophilus caerulescens) is a sexually dimorphic suboscine passerine bird that is distributed along the southern portion of the circum-Amazonian belt. It comprises eight currently recognized subspecies that exhibits extreme levels of plumage variation. Our objective was to describe the phylogeographic and demographic history of Thamnophilus caerulescens using Ultraconserved Elements (UCEs). We inferred populational structure and divergence times, as well as modeled the demographic history of the species based on comprehensive sampling across the entire distribution of the species. Structure analyses allowed to identify three genomic clusters within the species: a) northeastern Atlantic Forests; b) southeastern Cerrado, central, and southern Atlantic Forests, and c) Chacoan and Andean populations. Demoraphic analyses revealed a history of gene flow, mainly between birds from the central and southern Atlantic Forest, the Chacoan, and Andean populations. Differentiation took place during the Pleistocene, with a possible origin in the northern Atlantic Forest during the Pliocene. The recent diversification of the Variable Antshrike was probably affected by series of humid and dry periods throughout the Quaternary, allowing the intermittent connection between 
the central-southern Atlantic Forests and the Chacoan - Andean populations, and, to a lesser extent, with the northern Atlantic Forest populations. 


\section{Introduction}

The Neotropics harbor the highest levels of species diversity and endemism across multiple taxonomic groups (Halffter, 1992; Mittermeier et al., 1998; Myers et al., 2000; Olson et al., 2001; Dinerstein et al., 2017). In general, the spatial distribution of Neotropical organisms results from large-scale geological processes, such as the uplift of the Andes, that generate opportunities for allopatric differentiation and promote diversification into novel environments (Hooghiemstra et al., 2002, Graham, 2009, Hoorn et al., 2010, Herzog et al., 2011, Prieto-Torres et al., 2018). These processes are also shaped by species' ecological affinities and dispersal abilities to disperse across barriers and persist over time (Burney \& Brumfield, 2009; Smith et al., 2014), resulting in a complex mosaic of distributional ranges, often shared by large numbers of co-distributed species, from which some general patterns have emerged. For instance, coarse distributional limits of South American taxa have allowed us to recognize the main domains of forested areas, such as the Atlantic Forest and Amazonia, or open areas such as the Llanos and the Cerrado (Darlington, 1957; Sánchez-González et al., 2008; Morrone, 2014; Prieto-Torres et al., 2018). However, there is prevalent taxon-specific and scale-dependent variation in demographic and geologic histories that obfuscate our understanding of the mechanisms driving the evolutionary history of co-existing populations (Smith et al., 2014).

Distributional patterns of Neotropical birds are largely bounded by the main biogeographic domains. Yet, there are numerous instances in which several widely distributed co-occurring taxa exhibit rather odd distributions that expand beyond the boundaries of these domains. One of these common patterns is known as the circum-Amazonian distribution (sensu Remsen et al., 1991), which largely mirrors the extend of Seasonally Dry Tropical Forests - SDTF (sensu Mooney et al., 1995) surrounding Amazonia (Chaco, Caatinga, Interandean valleys) but that expands into 
neighboring forested formations in seasonal savannah environments (Cerrado, Llanos, Pampas) and humid forests (Atlantic Forest, Andean Foothills, Guiana Shield). The circum-Amazonian distribution is shared by a considerable number of species of birds, insects, and plants (Bates, 1997; Lovette, 2004; Knapp, 2002; Irmler, 2009) but we still lack a thorough understanding of the historical events and evolutionary processes generating this pattern.

Although a wealth of hypotheses about the origin and maintenance of diversity in the Neotropics has been proposed for the Amazonia (reviewed by Haffer, 1997), they can be relevant shed light on the circum-Amazonian patterns of distribution. For example, hypotheses based in the presence of rivers acting as barriers between populations - the Riverine Hypothesis (Sick, 1967; Capparella, 1988; Wallace, 1854) - could explain the distribution of some species with an incomplete/intermittent circum-Amazonian distribution (an idea proposed for Amazonian taxa, initially by Wallace, 1854). In the same way, the Refugia Hypothesis (Haffer, 1969; Vanzolini \& Williams, 1970), that proposes that the biodiversity in Amazonia was molded by a series of climatic fluctuations during the Cenozoic producing a reduction of the Neotropical Forests, could be extrapolated to explain the diversification of species of this distribution. In addition, the combined effect of these rivers and the refugia created during the dry glacial periods in the Quaternary would be another suitable explanation for circum-Amazonia taxa (River-refuge Hypothesis Haffer, 1993). Lastly, it is possible that geological processes (tectonic movements and level sea fluctuations) influence (indirectly) the diversity/distribution of species/subspecies allowing the isolation and re-connection among the different areas of the circum-Amazonian region(s) (Paleogeography Hypothesis, Croizat, 1976).

The Variable Antshrike (Thamnophilus caerulescens) is a suboscine passerine that exhibits circum-Amazonian distribution. It inhabits the forest understory, second-growth woodland, and 
patches of thickets and trees in more open regions, and can be found in patches of degraded remnants of forest (Zimmer \& Isler, 2019). The Variable Antshrike is sexually dimorphic and exhibits extreme levels of plumage variation across its range. Hence, taxonomists have recognized a number of subspecies, some of which have been recently synonymized (see Zimmer \& Isler, 2019), that exhibit clinal variation in vocalizations and plumage (Brumfield, 2005; Isler et al., 2005). Although this high levels of phenotypic variation lacking clear-cut geographic structure are extraordinary in the avian world, a thorough understanding of the mechanisms giving rise to the remain poorly understood.

Ultraconserved Elements (UCEs Bejerano et al., 2004) are highly conserved genomic sequences that allow the use of a large set of universal markers to infer relationships among lineages (Faircloth et al., 2012; Faircloth et al., 2015). The estimation of demographic and population parameters based on UCE data has been shown to improve relative to those based on mtDNA or other genomic markers (Smith et al., 2013). For example, Zarza et al. (2018) used UCEs to identify the demographic patterns in some groups of vertebrates. In the same way, Myers et al. (2019) infer historical demography in a species of snakes. Also, UCEs were used to delimitation of species (Ješovnik et al., 2017; Pie et al., 2017).

Here, we describe the large-scale phylogeographic and demographic history of Thamnophilus caerulescens using genome-scale. Specifically, we used ultraconserved Elements (Faircloth et al., 2012; UCEs) to a) describe the populational structure and estimate divergence times, and b) identify plausible historical and evolutionary processes responsible for generating the circum-Amazonian distributional pattern of T. caerulescens. Specifically, we aim at testing scenarios such as a possible isolation among their populations after an initial period of expansion due to climatic fluctuations in the Cenozoic, and assess migration events between populations 
during the Quaternary. To this end, we use demographic modeling to test for different scenarios contemplating different rates and directions of migration and growth rates across populations of T. caerulescens. In addition, we describe a plausible phylogeographic scenario of the species and propose one possible change to refine the taxonomy of this polytypic taxon. The evolutionary and demographic information of the populations of T. caerulescens will be useful to shed light on the role of lineage-specific histories and idiosyncrasies in shaping circum-Amazonian populations. 


\section{Methods}

Sampling and DNA extractions

We sampled a total of 53 vouchered specimens of $T$. caerulescens, covering the total extent of its geographical distribution and including at least two individuals of each of the eight subspecies currently recognized (but see T. c. ochraceiventer, taxonomy sensu Zimmer \& Isler 2019, Table S1; Fig. 1a). Additionally, following results by Brumfield and Edwards (2007), we sampled five vouchered specimens of the closely related species $T$. aethiops. We extracted total genomic DNA from muscle tissues using the PureLink ${ }^{\circledR}$ Genomic DNA Mini kit (Invitrogen Inc) and following guidelines by the manufacturer. We quantified genomic DNA concentrations using a Qubit 2.0 fluorometer with the dsDNA BR assay kit (Life Technologies, Inc).

\section{Mitochondrial DNA}

We sequenced the mitochondrial gene NADH dehydrogenase 2 (ND2) from all individuals of $T$ caeurlescens and 5 individuals of the outgroup. We amplified and sequenced ND2 using standard PCR and Sanger sequencing protocols described elsewhere (Brumfield et al., 2007). We edited sequences and checked that they did not include stop codons or anomalous residues using Geneious v. 11.1 .4 (www.geneious.com, Kearse et al. 2012). We aligned sequences with the MAFFT v.7 multiple alignment plugin (Katoh \& Standley, 2013) implemented in Geneious. Newly obtained sequences were deposited in GenBank (Accession numbers XXXXX-XXXXXX). 
We built a Median Joining Network - MJN - haplotype network (Bandelt et al., 1999) implemented in POPART (Leigh \& Bryant, 2015). Outgroup samples and short ingroup sequences ( $<700 \mathrm{bp}$ ) were excluded from the analysis and the matrix was trimmed to exclude any positions containing missing data (Final 1,041 bp, 53 samples).

Using the corrected Akaike Information Criterion (AICc; Hurvich and Tsai 1989) implemented in jModeltest2 (Darriba et al., 2012) on the Cipres Science Gateway V 3.3 (Miller et al., 2010), we selected a $\operatorname{TrN}+\mathrm{I}+\mathrm{G}$ model as the best substitution model. We estimated a timecalibrated gene tree within a Bayesian framework implemented in the program BEAST2 v2.4.4 (Bouckaert et al. 2014). Based on the avian mtDNA substitution rate of $2.1 \%$ My (Weir \& Schluter, 2008), we used a lognormal relaxed molecular clock with a mean rate of 0.0105 for mtDNA. We used a Coalescent Constant Population prior with no restrictions on tree shape and a randomly generated tree as a starting tree. We ran analyses for a total of 50 million generations with a sampling frequency of 1,000. We determined that replicate analyses converged (effective sample size values > 400) using Tracer 1.7.1 (Rambaut et al. 2018). Using TreeAnnotator v2.4.4 (Drummond et al. 2012, Bouckaert et al. 2014) and a burn-in of 30\%, we estimated a posterior distribution of topologies and a 50\% maximum clade credibility (MCC) tree.

\section{Sequence capture}

Based on results of the mitochondrial analyses, we selected 28 samples of $T$. caerulescens and three samples of T. aethiops to sequence ultraconserved elements (UCEs; Faircloth et al., 2012) following a target enrichment approach. The genomic enrichment and Illumina sequencing was performed by Rapid Genomics (Gainesville, FL) using 1,000 ng of input genomic DNA for each 
sample. Libraries were enriched from 2,386 UCE loci that targeted a set of 2,560 probes (Faircloth et al., 2012, Tetrapods-UCE-2.5K version 1; Microarray, Ann Arbor, MI), following an opensource protocol available at www.ultraconserved.org. Samples were multiplexed at 192 samples per lane on a 125 bp paired-end Illumina HiSeq 2500 run, yielding an average coverage of $18.61 \mathrm{X}$ per sample.

Edition and assembly of UCEs

We followed the Phyluce pipeline (Faircloth, 2016, https://github.com/faircloth-lab/phyluce) to process the raw reads and assembly contigs corresponding to target loci. Initially, Illumiprocessor 2.0.7 (Faircloth, 2013) and Trimmomatic 0.32 (Bolger et al., 2014) were used to trimm adapters, barcodes and low quality regions. We used Trinity 2.0.6 (Grabherr et al., 2011) to perform the assembly (script phyluce_assembly_assemblo_trinity). To avoid including markers of different ploidy, we identified, extracted, and removed Z-linked UCEs from the assemblies using Blast 2.7.7 (see Altschul et al., 1990; Camacho et al., 2009). Finally, we implemented the script phyluce_assembly_match_contigs_to_probes to match the assembled contigs to the UCE probes (uce-2.5k-probes.fasta). The results were exported in a $*$ fasta.

Single Nucleotide Polymorphism (SNP) calling

We extracted Single Nucleotide Polymorphisms (SNPs) from the UCE alignments using the methods described by Harvey et al. (2016), which are largely based on Phyluce (Faircloth, 2016). We extracted SNPs following two approaches using the script phyluce_assembly_match_counts. 
The first one yielded a $100 \%$ complete matrix with no missing data for any individual in all loci (individuals $=28$, loci $=324$ ), and the second one yielded an incomplete matrix including all data matching the target loci (individuals $=28$, loci $=2,036$ ). When outgroups were included these matrices contained 201 and 1,954 loci, respectively. The average number of loci per individual was 2,004 and the average number of individuals per locus was 27.

To call SNPs, we first created a *fasta file with the loci extracted from each matrix (phyluce_assembly_explode_get_fastas_file) and we chose as reference the individual with the deepest coverage and longest mean length of recovered contigs (script phyluce_assembly_get_trinity_coverage, and phyluce_assembly_get_fasta_lengths). Then, we used bwa 0.7.7 (Li \& Durbin, 2009) to map raw reads from the samples for each group with their respective reference ( $\mathrm{Li}$, 2013), Samtools 0.1 .19 (Li et al., 2009) and Picard (http://broadinstitute.github.io/picard/) to create *bam files, mark duplicates from the PCRF and prepare the files for the next phase. We used GATK 3.8.0 (McKenna et al., 2010) to extract indels, SNPs, and phase sequences. Created $*_{v c f}$ files were exported into other formats for downstream demographic analyzes (*nexus, *sfs.gz). Finally, we filtered loci in the complete and incomplete *vcf by selecting one random SNP per locus from the biallelic SNPs recovered in each file (script randSnps.pl). Before filtering, our datasets contained 324 and 2.036 SNPs in the complete and incomplete matrices, respectively. After filtering, whereas In the end, we have two SNPs dataset: one with 324 loci (from the complete matrix) and another with 2,036 loci (incomplete matrix). We implemented all the analysis in this work on the two matrices to compare the results in each of them. 


\section{Population structure}

To infer population structure from the SNPs, we implemented two multivariate approaches; a Principal Components Analysis (PCA) with the R packages adegenet/ape (Jombart, 2008 and Paradis et al., 2004), and a coefficients of mixture analyses with sparse nonnegative matrix factorization for clustering (sNMF) in the R package LEA (Frichot et al., 2014, Frichot \& François, $2015)$ with the following parameters; five $\alpha$ values $(10,50,100,500,1000), \mathrm{K}$ values of 1 to 10 ( $\mathrm{K}=1: 10$ ), and 100 runs per $\mathrm{K}$ value, and the minimum cross entropy as TRUE to estimate the best number of K. Additionally, we implemented a Discriminant Analysis of Principal Components (DAPC; Jombart et al., 2010) within the adegenet package recovering PCs with $80 \%$ of variance, and a maximum of 10 groups.

\section{Species trees and gene trees}

We ran two million iterations in SNAPP (Bryant et al., 2012) to identify the relationships among the clusters recovered in the PCA and sNMF analyzes using the SNPs extracted from the UCEs. Therefore, we tested three possible scenarios. The first one considered all the samples from $T$. caerulescens and T. aethiops (outgroup) to test the monophily of T. caerulescens. The second one considered T. caerulescens divided into three clusters: a) northern Atlantic Forest; b) the remaining samples of T. caerulescens; and c) T. aethiops. The third scenario included five clusters: a) northern Atlantic Forest; b) southeastern Cerrado, central and southern Atlantic Forest; c) Chaco; d) Andes; and e) T. aethiops. We used Tracer 1.7.1 (Rambaut et al., 2018) and Figtree 1.4.4 (Rambaut, 2009) to evaluate and visualize the results. 


\section{Demographic history}

We used the software momi2 (https://github.com/popgenmethods/momi2) to infer possible demographic scenarios in $T$. caerulescens. momi2 used a SFS file that can be obtained from the SNPs extracted from the UCEs to infer demographic histories by fitting the observed value of the SFS to its expected value in a composite likelihood framework (Kamm et al., 2018). In this way, multiple demographic models were tested and the most informative was selected using the Akaike Information Criterion (AIC, Akaike, 1973). We tested multiple models with different demographic scenarios for the populations in T. caerulescens, based on the results of PCA, DAPC, and sNMF analyzes. Thus, we tested three main types of models (Fig. 2, all models in Figure S1a-S1b) on a scenario with three clusters: a) northern Atlantic Forest; b) southeastern Cerrado, central and southern Atlantic Forests; and c; the Andean and Chacoan populations. The first group of models infer possible events of migration and divergence times among the three clusters (Fig. 2a); the second group includes the parameters of the first group plus possible events of expansion of the caerulescens and Andean clusters (Fig. 2b). Finally, the third group of models includes a bottleneck event in the northern Atlantic Forest cluster after the split from the remaining populations (Fig 2c).

For each model, we implemented 100 runs to avoid suboptimal results. Based on the run with the highest likelihood for each model, we evaluated the relative weight of the best model using the Akaike Information Criterion (AIC, Akaike, 1973). Finally, we ran 100 bootstrap simulations to estimate confidence intervals of the parameters of the best selected model. 


\section{Results}

Time calibration based on mtDNA

Preliminary analyses of the 53 ND2 sequences identified 30 unique haplotypes and a considerable levels of admixture among the individuals of populations collected (Fig. 1b). Maximum-likelihood and Bayesian phylogenetic reconstructions showed four strongly supported groups: a) northern Atlantic Forest; b) southeastern Cerrado, central and southern Atlantic Forest; c) Chaco; and d) Andes (see Supplementary information, Fig. S2a-S2b).

Analyses of divergence times estimated that $T$. caerulescens diverged from its closest relatives close to 5 Mya [6.5 - 3.6 Mya] in the Zanclean period of the early Pliocene. The primary divergence between the population of the northern Atlantic Forest and the others populations took place around 1.2 Mya [1.7 - 0.8 Mya] during the Calabrian stage of the Pleistocene. The diversification of the remaining clusters took place during the Middle Pleistocene [0.8 - 0.3 Mya], showing that $T$. caerulescens has deversified primarly during the last million years (Fig. 3a).

\section{Genomic data quality}

We recovered 5,702,659 reads per sample $(\mathrm{N}=28 ; \min =1,904,001$ and $\max =10,284,782)$ after trimming. The assembly produced 17,803 contigs per sample (total $=498,503$, $\min =4,888$, $\max =143,662)$ with an average length of $464.53 \mathrm{bp}$, for a total of $185,331,752 \mathrm{bp}$. Were recovered a total of 4,697 contigs with more of $1 \mathrm{~kb}$ of length (2,385 from 2,560 loci in the Tetrapods-UCE2.5K probe). We built two SNPs datasets one with 324 and another with 2,036 loci with the 
samples of T. caerulescens (see Methods: SNP calling). Here we show unified results, but when results differed between the two datasets, we will show both.

\section{Population structure}

Principal component analyses support the existence of three genetic clusters within $T$. caerulescens (Fig. 3b). One group represented the northernmost region of the Atlantic Forest (subspecies cearensis), the second one included individuals from the southeastern Cerrado and the central and southern Atlantic Forest (subspecies caerulescens, gilvigaster, and ochraceiventer), and the third one comprised populations in the Andean and Chacoan regions (remaining subspecies). Analyses based on the incomplete matrix showed further structure within this last group: one Andean cluster (subspecies aspersiventer and melanochrous) and one Chacoan cluster (subspecies dinellii and paraguayensis; Fig. S3). In addition, structure in this third group reflected a pattern of continuous or clinal variation running from north to south (melanochrous - aspersiventer dinellii/paraguayensis; Fig. S4a-S4b), consistent with previous description of phenotypic and genetic variation in Bolivia (Brumfield, 2005; Isler et al., 2005).

The sNMF analyses also infer the three main clusters described above (Fig. 3c). However, the use of different values of the $\alpha$ regularization parameter and the use of either the complete or the incomplete matrix, could alter the number of identified clusters (see Table S2 and Fig. S5). With the complete matrix the number of inferred groups varied from two to five, whereas the incomplete matrix led to defining two or three clusters. Most importantly, the main pattern that emerged from these results is that highest levels of admixture were primarily observed in those individuals in the Andean and Chacoan populations (see Tables S3 - S4 from DAPC). 
Species trees and gene trees

Under the scenarios analyzed, SNAPP consistently showed that $T$. caerulescens, as currently defined, is monophyletic and is composed of three well-supported groups (Fig. 4a). The firest one corresponds to the northern Atlantic Forest group (hereafter cearensis group), the second one to the the Andes and Chaco populations (hereafter Andean group), and the third one to the eastern Cerrado, central and southern Atlantic Forest (hereafter caerulescens group). Support levels using both complete and incomplete matrices varied, but groupings and topologies were congruent.

\section{Demographic history}

The demographic history of the cearensis, caerulescens, and Andean groups was best explained by models considering asymmetrical gene flow. For the complete matrix (Fig. 5a), the most informative model proposed unidirectional asymmetrical migration (cearensis $\rightarrow$ caerulescens $\rightarrow$ Andean, $\log -1 \mathrm{lik}=-1229.45$, AIC $=2476.91 \omega_{\mathrm{i}}=1$; Table 1). In this model, the events of migration took place after the LGM (cearensis $\rightarrow$ caerulescens 19,228 year; caerulescens $\rightarrow$ Andean 10,000 years). Additionally, the percentage of migrations was higher from the caerulescens $\rightarrow$ Andean populations that the cearensis $\rightarrow$ caerulescens, congruent with the patterns of admixture showed in the sNMF analyses. After bootstrapping, we dated the divergence of the cearensis from the others groups approximately 743,054 years ago (95\% CI 700,975 - 785,133), whereas the Andean - caerulescens divergence took place 385,122 years ago (95\% CI 361,096 - 409,149). 
For the incomplete matrix (Fig. 5b), a model with bidirectional and asymmetrical migration was identified as the best (cearensis $\leftarrow \rightarrow$ caerulescens $\leftrightarrow \rightarrow$ Andean, log-lik $=-7274.51$, AIC $=$ 14,575.02; $\omega_{\mathrm{i}}=1$, Table 2). After bootstrapping, we dated the divergence of the cearensis from the others groups approximately 630,469 years ago (95\% CI 616,307-644,631), whereas the Andean - caerulescens divergence occurred 377,685 years ago (95\% CI 367,612 - 387,758). In this model, the events of migration took place before and after the LGM. The migration from cearensis $\rightarrow$ caerulescens occurred 25,526 year ago. The caerulescens $\rightarrow$ Andean migration occurred 365,700 years ago, and the Andean $\rightarrow$ caerulescens migration 13,857 years ago). Additionally, the percentage of migrations was higher in the caerulescens $\leftarrow$ Andean populations that in the cearensis $\rightarrow$ caerulescens, congruent with the patterns of admixture identified. In general, the divergence events between populations of $T$. caerulescens occurred during the Middle Pleistocene $(0.78-0.12 \mathrm{Myr})$, consistent with the results obtained with mitochondrial phylogenetic analyses. However, the divergence between the northern Atlantic Forest (the cearensis group) and the other populations were older in the ND2 analysis (835,592 years, Calabrian). Similarly, incomplete and complete matrices differed in the time of divergence of cearensis group from all other populations and in the time of the events of migration. However, there is a consistent signal of the idea that cearensis is the most divergent and isolated population in T. caerulescens and that the percentage of migration between caerulescens and the Andean group is higher than that between cearensis and caerulescens. 


\section{Discussion}

\section{Population structure in Thamnophilus caerulescens}

This is the first phylogeographic study about the Variable Antshrike ( $T$. caerulescens) using genomic data. Previous research focused on specific populations and mitochondrial DNA only (Brumfield, 2005; Isler et al., 2005) or as part of analyses at a higher taxonomic level (Brumfield \& Edwards, 2007). Here, we identified three main genetic clusters in the Variable Antshrike: cearensis in the northern Atlantic Forest, caerulescens in the southeastern Cerradao, central, and southern Atlanic forest, and an Andean - Chacoan group. These results are congruent across phylogenetic, structure, and demographic analyses and they provide a good starting point toward the understanding of the demographic history of this species, as well as the mechanisms underlaying circum-Amazonian distributions.

Moreover, these results highlight the high levels of admixture in the Andean and Chacoan populations, all of which are phenotypically distinct and that seem to be varying clinally, as previously suggested based on mitochondrial, plumage, and vocal data (Brumfield, 2005; Isler et al., 2005). Clinal variation has been described in a number of Andean birds (Graves, 1991; Areta \& Pearman, 2013; Doren et al., 2018; Seeholzer \& Brumfield, 2018) and other taxa (Premoli, 2003), but mechanisms driving this pattern remain to be studied in greater detail. Some of the most likely explanations largely fall within the realm of local adaptation in response to latitudinal and environmental gradients, geological events, climatic variation during the Pleistocene, secondary contact between isolated populations, and hybridization (Miller et al., 2010b; Herzog \& Kattan, 2011; Luebert \& Weigend, 2014; Chattopadhyay et al., 2017; Polato et al., 2018). For T. 
caerulescens, a larger sampling effort and others methodological approaches will be necessary to clarify this phenomenon in specific.

In addition, it seems that there is an effect of the amount of data used on the ability to detect population structure. The level of resolution of PCA and sNMF analyses was affected possibly because the number of loci was dramatically reduced (324 loci from the 2,036 in the incomplete matrix), likely representing information loss. Frichot et al. (2014) warns about the influence of the $\alpha$ parameter (regularization parameter $\alpha$ ) in the results in the sNMF program, especially in the complete matrix dataset. It is could be a factor that allowed discordant results (multiple $K$ values for different $\boldsymbol{\alpha}$ values). The level of admixture among the clusters varies between the two matrices and is affected for $\boldsymbol{\alpha}$ parameter, but it is clear that there was a considerable genic flow among the clusters, mainly between the caerulescens and Andean groups.

\section{Demography and biogeographical remarks}

Mitochoondrial estimates indicated that $T$. caerulescens diverged from its closest relative between 6.5 and 3.6 Mya, a time older than estimated by Brumfield \& Edwards (2007) for the 'montane $T$. caerulescens clade' (1.6 Myr), whereas the most recent divergences within the $T$. caerulescens started to take place close to 1.2 Mya during the Pleistocene. These values are older than those inferred in demographic analyses (0.75/0.63 and 0.38/0.37 Myr, complete/incomplete matrices), but a direct comparison between these two analyses could be difficult, given that they are based on different methodological approaches. The mitochondrial gene ND2 is thought to evolve at a unique clock-like substitution rate, whereas UCEs represent a wider spectrum of the heterogeneous history of the genome comprising hundreds of loci with hundreds of possible different rates. 
Demographic analyses identified as the best models those scenarios with migration from cearensis $\rightarrow$ caerulescens $\rightarrow$ Andean and bidirectional migrations among all them (complete and incomplete matrix, respectively), without expansion or bottleneck effects affecting their populational size. In addition, the migration rate between the caerulescens $\leftarrow \rightarrow$ Andean groups is higher than that with cearensis. The underlying explanation of these models can be grounded on various hypotheses proposed for the diversification of Neotropical organisms. For example, climatic fluctuations leading to forest retractions and expansions (i.e., Refuge Hypothesis; Haffer, 1969; Vanzolini \& Williams, 1970) during the Cenozoic have been a recurrent explanation for diversification of lineages of multiple taxonomic groups (see Richardson et al., 2001; Thomaz et al., 2015; Pérez-Escobar et al., 2017; García-Vázquez et al., 2017; Leal et al., 2018). The formation of refuges during cycles of humid and dry periods in the Quaternary has been described as one of the main mechanisms driving the proliferation of new lineages. For non-Amazonian regions, refuges has been proposed as drivers of differentiation and speciation in some species (Carnaval \& Moritz, 2008; Campagna et al., 2012; Ramos et al., 2018; de Oliveira Miranda et al., 2019). Following this reasoning, the early divergence and the high level of differentiation of cearensis from the others could be a consequence of the persistence of a refuge in the northeastern Brazil (the Pernambuco refuge, see Carnaval \& Moritz, 2008; Carnaval et al., 2009) during the Pliocene-Pleistocene, and the barrier effect of Rio São Francisco (i.e., Riverine Hypothesis; Sick, 1967; Capparella, 1988; Wallace, 1854). This region has been also considered a center of endemism for passerine birds (Silveira et al., 2003; da Silva et al., 2004) and has been represented as a unit separated from the central-southern Atlantic Forest in subsequent works (Batalha-Filho et al., 2013; DaSilva et al., 2015). On the other hand, Carvalho et al. (2017) and MaldonadoCoelho et al. (2013) showed that in the Atlantic Forests rivers are not efficient primary barriers to 
break the migration among populations, with climatic fluctuations ('bioclimatic units' based in altitudinal gradients) having a greater impact on these regions (Carnaval \& Moritz, 2008). In the T. caerulescens case, it is possible that the São Francisco River currently acts as a secondary barrier, preventing gene flow between the northern and the central/southern Atlantic Forest populations (D'horta et al., 2011; Werneck et al., 2012).

The level of admixture and the migration rate between the caerulescens and Andean clusters suggest a recent expansion and a possible incipient differentiation of these populations. It is plausible that, after an expansion period (late Miocene - early Pleistocene, see Prates et al., 2017), these two clusters began to separate due the isolation during the Quaternary, but maintaining considerable amounts of intrapopulational gene flow, and, to a lesser extent, along an Atlantic Forest - Cerrado - Chaco corridor. There are some examples about the connections between the eastern forests in Brazil and the Andes. For example, Batalha-Filho et al. (2013) suggests a plausible connection between some species of Synallaxis from the central-south Atlantic Forest and the Andes during the Pleistocene. In addition, Trujillo-Arias et al. $(2017,2018)$ shows that there were possible connections between the Atlantic Forest and central Andes during the Pleistocene, possibly through Cerrado and Chaco ecoregions (see Cabanne et al., 2019).

The existence of these corridors are consistent with the Pleistocene Arch Hypothesis (PAH, Prado \& Gibbs, 1993; Mogni et al., 2015). The PAH could be invoked to explain these demographic scenarios, wherein a continuum of relatively stable areas of non-Amazonian forests (Seasonally Dry Tropical Forests - SDTFs -) allows the migration and colonization of taxa during the Cenozoic. Under this scenario, T. caerulescens could have migrated southward from the territory currently comprised by northeastern Brazil colonizing the Chacoan and central Andean regions during the Quaternary. Climatic cycles during this same period could also have allowed 
the posterior isolation of different populations. For example, Florentín et al. (2018) suggest that the existence of these connections between areas of SDTFs from the eastern Brazil and the Chacoan region was an important force in the diversification of the plant genus Galianthe. However, Arruda et al. (2018) concluded that the presence of refugia had a greated effect on the diversification of organisms than the presence of a continuum of forested areas, at least during the last $21 \mathrm{ka}$. Similarly, Werneck et al. (2011) reject the idea of a stable PAH connecting patches of SDTF in those areas known today as the Caatinga, Cerrado and Chaco and proposed an alternative scenario in which such an arch might have existed earlier, either during the Lower Pleistocene or the Tertiary) followed by cycles of fragmentation and secondary expansion during the Holocene. Although our results are inconclusive as to whether such SDTF corridor was present during the Pleistocene or the late Tertiary, they are consistent with the idea of a once continuous population that underwent divergence and subsequent secondary contact during the Pleistocene. In that sense, the idea of refugia in northeastern Brazil (cearensis), the forested areas of the Cerrado and the central and souther Antlantic Forest (caerulescens) and the Andean-Chacon regions are consistent with the demographic parameters and population structure of T. caerulescens. Further expansion, was possibly affected by the Rio São Francisco and the Rio Paraná, which seem to be playing an a role in maintaining, to some extent, the separation between cearensis and caerulescens and caerulescens and Andean populations, respectively.

\section{A likely scenario for the demographic history of T.caerulescens}

The results of our analyses suggests that the history of $T$. caerulescens began in the Late MiocenePliocene, with an initial population that originated in the northern Atlantic Forest (Pernambuco 
refuge sensu Carnaval \& Moritz, 2008) and expanded southward during the Pleistocene, thereby colonizing the Cerrado, central and southern Atlantic Forests, the Chaco and the central Andes (Fig. 5b). In this way, while the northern Atlantic Forest populations remained isolated via climatic and geological secondary barriers, the two last groups of populations have maintained intermitent contact due to cycles of retractions and expansions of their habitat during the PleistoceneHolocene, with a considerable grade of hybridization and polymorphism (phenotypic/genetic clinal variation). This scenario is partially congruent with that proposed by Brumfield \& Edwards (2007) for the Variable Antshrike, in which the geographical origin of the species was placed in the 'lowlands of eastern Brazil'. However, the authors did not have enough power to infer whether those 'lowlands' were located in northern, central, or southern portions of eastern Brazil (see Brumfield, 2005). On the other hand, Thomé et al. (2010) refute the idea of taxa diverged initially in northern Atlantic Forest with posterior expansion via southward in the Pleistocene using data from some endemic species of toads, with simultaneous presence of central-southern refugia in the Atlantic Forest in the same period of time.

The most intriguing situation regarding the evolutionary history of $T$. caerulescens is related to the patterns and processes driving the outstanding phenotypic differentiation within the the Andean and Chacoan regions. These populations represent an extremely heterogeneous cluster of phenotypically distinct individuals with relatively shallow, albeit somewhat structured, genetic diverences. There is robust evidence of clinal plumage, vocal, and mitochondrial variation (Brumfield, 2005; Isler et al., 2005), but a most intense sampling effort, both geographic and genetic, will be necessary to elucidate the causes of this variation. 


\section{Taxonomic considerations}

Although this work does not aim at conducting a taxonomic revision of T. caerulescens, here we have sufficient information to propose one modification in the taxonomy of the species. The considerable genetic differentiation and geographical isolation of the northern Atlantic forest populations in the species would be sufficient evidence to elevate the subspecies $T$. caerulescens cearensis to species-level status. In addition, the plumage pattern of cearensis is diagnosable from that of nominal form, with a 'male with less black on crown and upperparts, while the female have a crown rufous, wing-coverts ochraceous olive-brown (edges brightest), tail tinged clay colour, throat pale ochraceous' (Zimmer \& Isler, 2019). We observed this plumage differentiation in specimens analyzed from the MZUSP (Museu de Zoologia da Universidade de São Paulo, Brazil). A formal taxonomic revision on Thamnophilus caerulescens has not been elaborated until now, and we believe that our study represents a starting point for a more in-depth taxonomic analysis on this species. 


\section{Final remarks}

The lineages identified here for Thamnophilus caerulescens are congruent with the geographical distribution of the species; having an isolate clade from northeastern Atlantic Forests, and other two with high level of admixture, plumage and vocal variation in the central-southern Atlantic Forests (plus eastern Cerrado) and Andes + Chaco. The level of admixture, times of divergence and demographic history support a scenario of recent diversification in the taxon, with climatic fluctuations during the Quaternary as its main influence. Specifically, the isolation of cearensis group could be increased by the presence of São Francisco River as a secondary barrier, illustrate an actual process of speciation. In this way, we think that the cearensis group (northern Atlantic Forest) has the potential to be considered a full taxonomic species. Finally, the species $T$. caerulescens needs a complete taxonomic review to corroborate this affirmation. 


\section{Acknowledgements}

We are grateful to the following museums and their staff for assistance in obtaining tissue samples:

Museu Paraense Emílio Goeldi (MPEG), University of Kansas (Biodiversity Institute, Division of Ornithology), Museu de Ciências e Tecnologia PUC-RS, Field Museum of Natural History (FMNH), and Fábio Raposo do Amaral.

\section{Funding}

Financial support was provided by Fundação de Amparo para a Pesquisa do Estado de São Paulo (FAPESP, project 2015/16092-7) and Coordenação de Aperfeiçoamento de Pessoal de Nível Superior (CAPES). The first author gratefully acknowledge financial support from the Frank M. Chapman Memorial Fund from the American Museum of Natural History (AMNH). 


\section{References}

Akaike, H. (1973). Information theory and an extension of the maximum likelihood principle. International Symposium Information on theory Information and an extension Theory, (pp. 267281).

Altschul, S. F., Gish, W., Miller, W., Myers, E. W., \& Lipman, D. J. (1990). Basic local alignment search tool. Journal of Molecular Biology, 215(3), 403 - 410.

Areta, J. I. \& Pearman, M. (2013). Species Limits and Clinal Variation in a Widespread High Andean Furnariid: The Buff-Breasted Earthcreeper (Upucerthia validirostris). The Condor: Ornithological Applications, 115(1), 131-142.

Arruda, D. M., Schaefer, C. E. G. R., Fonseca, R. S., Solar, R. R. C., \& FernAndes-Filho, E. I. (2018). Vegetation cover of Brazil in the last $21 \mathrm{ka}$ : New insights into the Amazonian refugia and pleistocenic arc hypotheses. Global Ecology and Biogeography, 27, 47-56.

Bandelt, H.-J., Forster, P., \& Röhl, A. (1999). Median-joining networks for inferring intraspecific phylogenies. Molecular Biology and Evolution, 16(1), 37-48.

Batalha-Filho, H., Irestedt, M., Fjeldså, J., Ericson, P. G. P., Silveira, L. F., \& Miyaki, C. Y. (2013). Molecular systematics and evolution of the Synallaxis ruficapilla complex (Aves: Furnariidae) in the Atlantic Forest. Molecular Phylogenetics and Evolution, 67, 86-94.

Bates, J. M. (1997). Distribution and geographic variation in three South American grassquits (Emberizinae, Tiaris). Ornithological Monographs, 48, 91-110.

Bejerano, G., Pheasant, M., Makunin, I., Stephen, S., Kent, W. J., Mattick, J. S., \& Haussler, D. (2004). Ultraconserved elements in the human genome. Science, 304, 1321-1325. 
Bolger, A. M., Lohse, M., \& Usadel, B. (2014). Trimmomatic: A flexible trimmer for illumina sequence data. bioinformatics. Bioinfor, 30(15), 2114-2120.

Bouckaert, R., Heled, J., Kühnert, D., Vaughan, T., Wu, C.-H., Xie, D., Suchard, M. A., Rambaut, A., \& Drummond, A. J. (2014). Beast 2: A software platform for bayesian evolutionary analysis. PLOS Computational Biology, 10(4), 1-6.

Brumfield, R. T. (2005). Mitochondrial variation in Bolivian populations of the variable Antshrike (THAMNOPHILUS CAERULESCENS). The Auk, 122(2), 414-432.

Brumfield, R. T. \& Edwards, S. V. (2007). Evolution into and out of the Andes: A bayesian analysis of historical diversification in Thamnophilus Antshrikes. Evolution, 61(2), 346-367.

Brumfield, R. T., Tello, J. G., Cheviron, Z., Carling, M. D., Crochet, N., \& Rosenberg, K. V. (2007). Phylogenetic conservatism and antiquity of a tropical specialization: Army-ant-following in the typical antbirds (Thamnophilidae). Molecular Phylogenetics and Evolution, 45, 1-13.

Bryant, D., Bouckaert, R., Felsenstein, J., Rosenberg, N. A., \& RoyChoudhury, A. (2012). Inferring species trees directly from biallelic genetic markers: Bypassing gene trees in a full coalescent analysis. Molecular Biology and Evolution, 29(8), 1917-1932.

Burney, C. \& Brumfield, R. (2009). Ecology predicts levels of genetic differentiation in Neotropical birds. The American Naturalist, 174(3), 358-368. PMID: 19627230.

Cabanne, G. S., Campagna, L., Trujillo-Arias, N., Naoki, K., Gómez, I., Miyaki, C. Y., Santos, F. R., Dantas, G. P. M., Aleixo, A., Claramunt, S., Rocha, A., Caparroz, R., Lovette, I. J., \& Tubaro, P. L. (2019). Phylogeographic variation within the buff-browed foliage-gleaner (Aves: Furnariidae: Syndactyla rufosuperciliata) supports an Andean-Atlantic forests connection via the Cerrado. Molecular Phylogenetics and Evolution. 
Camacho, C., Coulouris, G., Avagyan, V., Ma, N., Papadopoulos, J., Bealer, K., \& Madden, T. L. (2009). Blast+: architecture and applications. BMC Bioinformatics, 10(1), 421.

Campagna, L., Benites, P., Lougheed, S. C., Lijtmaer, D. A., Giacomo, A. S. D., Eaton, M. D., \& Tubaro, P. L. (2012). Rapid phenotypic evolution during incipient speciation in a continental avian radiation. Proceedings of the Royal Society of London B: Biological Sciences, 279, 1847-1856.

Capparella, A. (1988). Genetic variation in Neotropical birds: implication for the speciation process. Acta XIX Congr. Intern. Ornith., 2, 1658-1664.

Carnaval, A. C., Hickerson, M. J., Haddad, C. F. B., Rodrigues, M. T., \& Moritz, C. (2009). Stability predicts genetic diversity in the Brazilian Atlantic Forest hotspot. Science, 323(5915), $785-789$.

Carnaval, A. C. \& Moritz, C. (2008). Historical climate modelling predicts patterns of current biodiversity in the Brazilian Atlantic Forest. Journal of Biogeography, 35(7), 1187-1201.

Carvalho, C. D. S., Nascimento, N. F. F. D., \& Araujo, H. F. P. D. (2017). Bird distributional patterns support biogeographical histories and are associated with bioclimatic units in the Atlantic Forest, Brazil. Zootaxa, 4337(2), 223-242.

Chattopadhyay, B., Garg, K. M., Gwee, C. Y., Edwards, S. V., \& Rheindt, F. E. (2017). Gene flow during glacial habitat shifts facilitates character displacement in a Neotropical flycatcher radiation. BMC Evolutionary Biology, 17(1), 210.

Croizat, L. (1976). Biogeografía analítica y sintética ('Panbiogeografía') de las Américas. Biblioteca de la Academia de Ciencias Físicas, Matemáticas y Naturales, 35, 1-890.

da Silva, J. M. C., de Sousa, M. C., \& Castelletti, C. H. M. (2004). Areas of endemism for passerine birds in the Atlantic Forest, South America. Global Ecology and Biogeography, 13(1), 85-92. 
Darlington, Jr., P. J. (1957). Zoogeography: The geographical distribution of animals. Jhon Wiley \& sons Inc.

Darriba, D., Taboada, G. L., Doallo, R., \& Posada, D. (2012). jmodeltest 2: more models, new heuristics and parallel computing. Nature Methods, 9(8), 772.

DaSilva, M. B., Pinto-da Rocha, R., \& DeSouza, A. M. (2015). A protocol for the delimitation of areas of endemism and the historical regionalization of the Brazilian Atlantic rain forest using harvestmen distribution data. Cladistics, 31(6), 692-705.

de Oliveira Miranda, N. E., Maciel, N. M., Lima-Ribeiro, M. S., Colli, G. R., Haddad, C. F. B., \& Collevatti, R. G. (2019). Diversification of the widespread Neotropical frog Physalaemus cuvieri in response to Neogene-Quaternary geological events and climate dynamics. Molecular Phylogenetics and Evolution, 132, 67-80.

D’horta, F. M., Cabanne, G. S., Meyer, D., \& Miyaki, C. Y. (2011). The genetic effects of late Quaternary climatic changes over a tropical latitudinal gradient: diversification of an Atlantic forest passerine. Molecular Ecology, 20(9), 1923-1935.

Dinerstein, E., Olson, D., Joshi, A., Vynne, C., Burgess, N. D., Wikramanayake, E., Hahn, N., Palminteri, S., Hedao, P., Noss, R., Hansen, M., Locke, H., Ellis, E. C., Jones, B., Barber, C. V., Hayes, R., Kormos, C., Martin, V., Crist, E., Sechrest, W., Price, L., Baillie, J. E. M., Weeden, D., Suckling, K., Davis, C., Sizer, N., Moore, R., Thau, D., Birch, T., Potapov, P., Turubanova, S., Tyukavina, A., de Souza, N., Pintea, L., Brito, J. C., Llewellyn, O. A., Miller, A. G., Patzelt, A., Ghazanfar, S. A., Timberlake, J., Klöser, H., Shennan-Farpón, Y., Kindt, R., Lilles ̃̃ $f$ Â, J.-P. B., van Breugel, P., Graudal, L., Voge, M., Al-Shammari, K. F., \& Saleem, M. (2017). An ecoregionbased approach to protecting half the terrestrial realm. BioScience, (pp. 1-12). 
Doren, B. M. V., Freeman, B. G., Aristizabal, N., Alvarez-R, M., Pérez-Emán, J., Cuervo, A. M., \& Bravo, G. A. (2018). Species limits in the Rusty-breasted Antpitta (Grallaricula ferrugineipectus) complex. The Wilson Journal of Ornithology, 130, 130 - 130 - 16.

Drummond, A. J., Suchard, M. A., Xie, D., \& Rambaut, A. (2012). Bayesian phylogenetics with beauti and the beast 1.7. Molecular Biology and Evolution, 29(8), 1969-1973.

Faircloth, B. C. (2013). illumiprocessor: a trimmomatic wrapper for parallel adapter and quality trimming.

Faircloth, B. C. (2016). Phyluce is a software package for the analysis of conserved genomic loci. Bioinformatics, 32(5), 786-788.

Faircloth, B. C., Branstetter, M. G., White, N. D., \& Brady, S. G. (2015). Target enrichment of ultraconserved elements from arthropods provides a genomic perspective on relationships among Hymenoptera. Molecular Ecology Resources, 15, 489-501.

Faircloth, B. C., Mccormack, J. E., Crawford, N. G., Harvey, M. G., Brumfield, R. T., \& Glenn, T. C. (2012). Ultraconserved elements anchor thousands of genetic markers spanning multiple evolutionary timescales. Systematic Biology, 61(5), 717-726.

Florentín, J. E., Arana, M. D., Prado, D. E., Morrone, J. J., \& Salas, R. M. (2018). Diversification of Galianthe species (Rubiaceae) in the Neotropical seasonally dry forests: a case study of a mainly subshrubby genus. Plant Ecology and Evolution, 151(2), 161-174.

Frichot, E. \& François, O. (2015). LEA: An R package for landscape and ecological association studies. Methods in Ecology and Evolution, 6, 925-929.

Frichot, E., Mathieu, F., Trouillon, T., Bouchard, G., \& François, O. (2014). Fast and efficient estimation of individual ancestry coefficients. Genetics, 196, 973-983. 
García-Vázquez, D., Bilton, D. T., Foster, G. N., \& Ribera, I. (2017). Pleistocene range shifts, refugia and the origin of widespread species in western Palaearctic water beetles. Molecular Phylogenetics and Evolution, 114, 122-136.

Grabherr, M. G., Haas, B. J., Yassour, M., Levin, J. Z., Thompson, D. A., Amit, I., Adiconis, X., Fan, L., Raychowdhury, R., Zeng, Q., Chen, Z., Mauceli, E., Hacohen, N., Gnirke, A., Rhind, N., di Palma, F., Birren, B. W., Nusbaum, C., Lindblad-Toh, K., Friedman, N., \& Regev, A. (2011). Full-length transcriptome assembly from RNA-Seq data without a reference genome. Nature Biotechnology, 29(7), 644-652.

Graham, A. (2009). The Andes: a geological overview from a biological perspective. Annals of the Missouri Botanical Garden, 96(3), 371-385.

Graves, G. R. (1991). Bergmann's rule near the equator: latitudinal clines in body size of an Andean passerine bird. Proc. Natl. Acad. Sci. USA., 88, 2322-2325.

Haffer, J. (1969). Speciation in Amazonian forest birds. Science, New Series, 165, 131-137.

Halffter, G. (1992). La Diversidad Biológica De Iberoamérica I, Volume I. Instituto De Ecología, A.C. Secretaria De Desarrollo Social.

Haffer, J. (1993). On the 'river effect' in some forest birds of southern Amazonia. Boletim do Museu Paraense Emilio Goeldi Serie Zoologia, 8(1), 217-245.

Haffer, J. (1997). Alternative models of vertebrate speciation in Amazonia: an overview. Biodiversity and Conservation, 6, 451-476.

Harvey, M. G., Smith, B. T., Glenn, T. C., Faircloth, B. C., \& Brumfield, R. T. (2016). Sequence capture versus restriction site associated DNA sequencing for shallow systematics. Systematic Biology, 65(5), 910-924. 
Herzog, S. K., Martínez, R., Jørgensen, P. M., \& Tiessen, H. (2011). Climate Change and Biodiversity in the Tropical Andes. IAI.

Herzog, S. K. \& Kattan, G. H. (2011). Patterns of Diversity and Endemism in the Birds of the Tropical Andes. In Climate Change and Biodiversity in the Tropical Andes, chapter 18, (pp. 245259). Inter-American Institute for Global Change Research (IAI) and Scientific Committee on Problems of the Environment (SCOPE), Paris.

Hooghiemstra, H., der Hammen, T. V., \& Cleef, A. (2002). Evolution of forests in the northern Andes and Amazonian lowlands during the Tertiary and Quaternary in Ecology of Neotropical rain forests. Editorial Cartago, Libro Universitario Regional (EULAC-GTZ), CR.

Hoorn, C., Wesselingh, F. P., ter Steege, H., Bermudez, M. A., Mora, A., Sevink, J., Sanmartín, I., Sanchez-Meseguer, A., Anderson, C. L., Figueiredo, J. P., Jaramillo, C., Riff, D., Negri, F. R., Hooghiemstra, H., Lundberg, J., Stadler, T., Sarkinen, T., \& Antonelli, A. (2010). Amazonia through time: Andean uplift, climate change, landscape evolution, and biodiversity. Science, 330, 927-931.

Hurvich, C. M. \& Tsai, C.-L. (1989). Regression and time series model selection in small samples. Biometrika, 76(2), 297-307.

Irmler, U. (2009). New species and records of the genus Lispinus with a key to the species from Peru (Coleoptera: Staphylinidae: Osoriinae). Zootaxa, 2263, 42-58.

Isler, M. L., Isler, P. R., Brumfield, R. T., \& Zink, R. M. (2005). Clinal variation in vocalizations of an antbird (Thamnophilidae) and implications for defining species limits. The Auk, 122(2), 433444.

Ješovnik, A., Sosa-calvo, J., Lloyd, M. W., Branstetter, M. G., Fernández, F., \& Schultz, T. R. (2017). Phylogenomic species delimitation and host-symbiont coevolution in the fungus-farming 
ant genus Sericomyrmex Mayr (Hymenoptera: Formicidae): Ultraconserved Elements (UCEs) resolve a recent radiation. Systematic Entomology, 42(3).

Jombart, T. (2008). adegenet: a $\mathrm{R}$ package for the multivariate analysis of genetic markers. Bioinformatics, 24(11), 1403-1405.

Jombart, T., Devillard, S., \& Balloux, F. (2010). Discriminant analysis of principal components: a new method for the analysis of genetically structured populations. BMC Genetics, 11(1), 94.

Kamm, J. A., Terhorst, J., Durbin, R., \& Song, Y. S. (2018). Efficiently inferring the demographic history of many populations with allele count data. bioRxiv.

Katoh, K. \& Standley, D. M. (2013). MAFFT Multiple Sequence Alignment Software Version 7: Improvements in Performance and Usability. Molecular Biology and Evolution, 30(4), 772-780. Kearse, M., Moir, R., Wilson, A., Stones-Havas, S., Cheung, M., Sturrock, S., Buxton, S., Cooper, A., Markowitz, S., Duran, C., Thierer, T., Ashton, B., Meintjes, P., \& Drummond, A. (2012). Geneious basic: An integrated and extendable desktop software platform for the organization and analysis of sequence data. BIOINFORMATICS, 28(12), 1647-1649.

Knapp, S. (2002). Assessing patterns of plant endemism in Neotropical uplands. The Botanical Review, 68(1), 22-37.

Leal, B. S. S., Medeiros, L. R., Peres, E. A., Sobral-Souza, T., Palma-Silva, C., Romero, G. Q., \& Carareto, C. M. A. (2018). Insights into the evolutionary dynamics of Neotropical biomes from the phylogeography and Paleodistribution modeling of Bromelia balansae. American Journal of Botany, 105(10), 1725-1734.

Leigh, J. W. \& Bryant, D. (2015). popart: full-feature software for haplotype network construction. Methods in Ecology and Evolution, 6(9), 1110-1116. 
Li, H. (2013). Aligning sequence reads, clone sequences and assembly contigs with bwa-mem. $\operatorname{arXiv.}$

Li, H. \& Durbin, R. (2009). Fast and accurate short read alignment with burrows-wheeler transform. Bioinformatics, 25(14), 1754-1760.

Li, H., Handsaker, B., Wysoker, A., Fennell, T., Ruan, J., Homer, N., Marth, G., Abecasis, G., Durbin, R., \& Subgroup. G. P. D. P. (2009). The sequence alignment/map format and samtools. Bioinformatics, 25(16), 2078-2079.

Lovette, I. J. (2004). Molecular phylogeny and plumage signal evolution in a trans Andean and circum Amazonian avian species complex. Molecular Phylogenetics and Evolution, 32, 512-523. Luebert, F. \& Weigend, M. (2014). Phylogenetic insights into Andean plant diversification. Frontiers in Genetics, 2, 27.

Maldonado-Coelho, M., Blake, J. G., Silveira, L. F., Batalha-filho, H., \& Ricklefs, R. E. (2013). Rivers, refuges and population divergence of fire-eye antbirds (Pyriglena) in the Amazon basin. Journal of Evolutionary Biology, 26, 1090-1107.

McKenna, A., Hanna, M., Banks, E., Sivachenko, A., Cibulskis, K., Kernytsky, A., Garimella, K., Altshuler, D., Gabriel, S., Daly, M., \& DePristo, M. A. (2010). The genome analysis toolkit: A MapReduce framework for analyzing next-generation DNA sequencing data. Genome Research, 20(9), 1297-1303.

Miller, M. A., Pfeiffer, W., \& Schwartz, T. (2010). Creating the CIPRES science gateway for inference of large phylogenetic trees. In Proceedings of the Gateway Computing Environments Workshop (GCE) (pp. 1-8). New Orleans, LA. 
Miller, M. J., Bermingham, E., Klicka, J., Escalante, P., \& Winker, K. (2010). Neotropical birds show a humped distribution of within-population genetic diversity along a latitudinal transect. Ecology Letters, 13(5), 576-586.

Mittermeier, R. A., Myers, N., Thomsen, J. B., da Fonseca, G. A. B., \& Olivieri, S. (1998). Biodiversity hotspots and major tropical wilderness areas: Approaches to setting conservation priorities. Conservation Biology, 12(3), 516-520.

Mogni, V. Y., Oakley, L. J., \& Prado, D. E. (2015). The distribution of woody legumes in Neotropical dry forests: the Pleistocene Arc Theory 20 years on*. Edinburgh Journal of Botany, 72(1), 35-60.

Mooney, H. A., Bullock, S. H., \& Medina, E. (1995). Introduction. In Seasonally Dry Tropical Forests, (pp. 1-8). Cambridge University Press.

Morrone, J. J. (2014). Biogeographical regionalisation of the Neotropical region. Zootaxa, 3782(1), 001-110.

Myers, E. A., Bryson, R. W., Hansen, R. W., Aardema, M. L., Lazcano, D., \& Burbrink, F. T. (2019). Exploring Chihuahuan Desert diversification in the gray-banded kingsnake, Lampropeltis alterna (Serpentes: Colubridae). Molecular Phylogenetics and Evolution, 131, 211-218.

Myers, N., Mittermeier, R. A., Mittermeier, C. G., da Fonseca, G. A. B., \& Kent, J. (2000). Biodiversity hotspots for conservation priorities. Nature, 403, 853-858.

Olson, D. M., Dinerstein, E., Wikramanayake, E. D., Burgess, N. D., Powell, G. V. N., Underwood, E. C., D’Amico, J. A., Itoua, I., Strand, H. E., Morrison, J. C., Loucks, C. J., Allnutt, T. F., Ricketts, T. H., Kura, Y., Lamoreux, J. F., Wettengel, W. W., Hedao, P., \& Kassem, K. R. (2001). Terrestrial ecoregions of the world: A new map of life on earth. BioScience, 52(11), 933938. 
Paradis, E., Claude, J., \& Strimmer, K. (2004). Ape: Analyses of phylogenetics and evolution in R language. Bioinformatics, 20(2), 289-290.

Pérez-Escobar, O. A., Chomicki, G., Condamine, F. L., Karremans, A. P., Bogarín, D., Matzke, N. J., Silvestro, D., \& Antonelli, A. (2017). Recent origin and rapid speciation of Neotropical orchids in the world's richest plant biodiversity hotspot. New Phytologist, 215(2), 891-905. 201723782.

Pie, M. R., Bornschein, M. R., Ribeiro, L. F., Faircloth, B. C., \& McCormack, J. E. (2017). Phylogenomic species delimitation in microendemic frogs of the Brazilian Atlantic forest. bioRxiv. Prado, D. E. \& Gibbs, P. E. (1993). Patterns of species distributions in the dry seasonal forests of South America. Annals of the Missouri Botanical Garden, 80, 902-927.

Polato, N. R., Gill, B. A., Shah, A. A., Gray, M. M., Casner, K. L., Barthelet, A., Messer, P. W., Simmons, M. P., Guayasamin, J. M., Encalada, A. C., Kondratieff, B. C., Flecker, A. S., Thomas, S. A., Ghalambor, C. K., Poff, N. L., Funk, W. C., \& Zamudio, K. R. (2018). Narrow thermal tolerance and low dispersal drive higher speciation in Tropical mountains. Proceedings of the National Academy of Sciences.

Prates, I., Melo-Sampaio, P. R., de Oliveira Drummond, L., Jr., M. T., Rodrigues, M. T., \& Carnaval, A. C. (2017). Biogeographic links between southern Atlantic forest and western South America: rediscovery, re-description, and phylogenetic relationships of two rare montane anole lizards from Brazil. Molecular Phylogenetics and Evolution, 113, 49 - 58.

Prieto-Torres, D. A., Cuervo, A. M., \& Bonaccorso, E. (2018). On geographic barriers and Pleistocene glaciations: Tracing the diversification of the russet-crowned warbler (Myiothlypis coronata) along the Andes. PLOS ONE, 13(3), 1-15. 
Premoli, A. C. (2003). Isozyme Polymorphisms Provide Evidence of Clinal Variation with Elevation in Nothofagus pumilio. Journal of Heredity, 94(3), 218-226.

Rambaut, A. (2009). Figtree version 1.3.1.

Rambaut, A., Drummond, A. J., Xie, D., Baele, G., \& Suchard, M. A. (2018). Posterior summarization in bayesian phylogenetics using tracer 1.7. Systematic Biology, 67(5), 901-904.

Ramos, E. K. S., de Magalhães, R. F., Marques, N. C. S., Baêta, D., Garcia, P. C. A., \& Santos, F. R. (2018). Cryptic diversity in Brazilian endemic monkey frogs (Hylidae, Phyllomedusinae, Pithecopus) revealed by multispecies coalescent and integrative approaches. Molecular Phylogenetics and Evolution, 132, 105-116.

Remsen, J. V., Rocha, O., Schmitt, C. G., \& Schmitt, D. C. (1991). Zoogeography and geographic variation of Platyrinchus mystaceus in Bolivia and Peru, and the circum-Amazonian distribution pattern. Ornitologia Neotropical, 2, 77-83.

Richardson, J. E., Pennington, R. T., Pennington, T. D., \& Hollingsworth, P. M. (2001). Rapid diversification of a species-rich genus of Neotropical rain forest trees. Science, 293(5538), 22422245.

Sánchez-González, L. A., Morrone, J. J., \& Navarro-Sigüenza, A. G. (2008). Distributional patterns of the Neotropical humid montane forest avifaunas. Biological Journal of the Linnean Society, 94, 175-194.

Sick, H. (1967). Rios e enchentes na Amazônia como obstáculo para a Avifauna. Atas Simp. Sobre a Biota Amazonica, 5, 495-520.

Seeholzer, G. F. \& Brumfield, R. T. (2018). Isolation by distance, not incipient ecological speciation, explains genetic differentiation in an Andean songbird (Aves: Furnariidae: 
Cranioleuca antisiensis, line-cheeked spinetail) despite near threefold body size change across an environmental gradient. Molecular Ecology, 27(1), 279-296.

Silveira, L., Olmos, F., \& J. Long, A. (2003). Birds in Atlantic Forest fragments in north-east Brazil. Cotinga, 20, 32-46.

Smith, B. T., Ribas, C. C., Whitney, B. M., Hernández-Baños, B. E., \& Klicka, J. (2013). Identifying biases at different spatial and temporal scales of diversification: a case study in the Neotropical parrotlet genus Forpus. Molecular Ecology, 22, 483-494.

Smith, B. T., McCormack, J. E., Cuervo, A. M., Hickerson, M. J., Aleixo, A., Cadena, C. D., Pérez-Emán, J., Burney, C. W., Xie, X., Harvey, M. G., Faircloth, B. C., Glenn, T. C., Derryberry, E. P., Prejean, J., Fields, S., \& Brumfield, R. T. (2014). The drivers of tropical speciation. Nature, $515,406-409$.

Thomaz, A. T., Malabarba, L. R., Bonatto, S. L., \& Knowles, L. L. (2015). Testing the effect of palaeodrainages versus habitat stability on genetic divergence in riverine systems: study of a Neotropical fish of the Brazilian coastal Atlantic Forest. Journal of Biogeography, 42(12), 23892401.

Thomé, M. T. C., Zamudio, K. R., Giovanelli, J. G., Haddad, C. F., Jr., F. A. B., \& Alexandrino, J. (2010). Phylogeography of endemic toads and post-Pliocene persistence of the Brazilian Atlantic Forest. Molecular Phylogenetics and Evolution, 55(3), 1018 - 1031.

Trujillo-Arias, N., Dantas, G., Arbeláez-Cortés, E., Naoki, K., Gómez, M. I., Santos, F. R., Miyaki, C. Y., Aleixo, A., Tubaro, P. L., \& Cabanne, G. S. (2017). The niche and phylogeography of a passerine reveal the history of biological diversification between the Andean and the Atlantic forests. Molecular Phylogenetics and Evolution, 112, 107 - 121. 
Trujillo-Arias, N., Calderón, L., Santos, F. R., Miyaki, C. Y., Aleixo, A., Witt, C. C., Tubaro, P. L., \& Cabanne, G. S. (2018). Forest corridors between the central Andes and the southern Atlantic Forest enabled dispersal and peripatric diversification without niche divergence in a passerine. Molecular Phylogenetics and Evolution, 128, 221 - 232.

Vanzolini, P. \& Williams, E. E. (1970). South American anoles: The geographic differentiation and evolution of the anolis Chrysolepis species group (Sauria, Iguanidae), volume 19 of Arquivos de Zoologia. Museu de Zoologia.

Weir, J. T. \& Schluter, D. (2008). Calibrating the avian molecular clock. Molecular Ecology, 17, 2321-2328.

Wallace, A. R. (1854). On the monkeys of the amazon. Annals and Magazine of Natural History, 14(84), 451-454.

Werneck, F. P., Costa, G. C., Colli, G. R., Prado, D. E., \& Sites Jr, J. W. (2011). Revisiting the historical distribution of seasonally dry tropical forests: new insights based on palaeodistribution modelling and palynological evidencegeb. Global Ecology and Biogeography, 20(2), 272-288.

Werneck, F. P., Gamble, T., Colli, G. R., Rodrigues, M. T., \& Sites, Jr, J. W. (2012). Deep diversification and long-term persistence in the South American 'dry diagonal': Integrating continent-wide phylogeography and distribution modeling of geckos. Evolution, 66(10), 30143034.

Zarza, E., Connors, E. M., Maley, J. M., Tsai, W. L., Heimes, P., Kaplan, M., \& McCormack, J. E. (2018). Combining ultraconserved elements and mtdna data to uncover lineage diversity in a Mexican highland frog (Sarcohyla; hylidae). PeerJ, 6, e6045. 
Zimmer, K. \& Isler, M. L. (2019). Variable Antshrike (Thamnophilus caerulescens). In J. del Hoyo, A. Elliott, J. Sargatal, D. Christie, \& E. de Juana (Eds), Handbook of the Birds of the World Alive. Lynx Editions, Barcelona. 


\section{Appendix (Chapter I)}
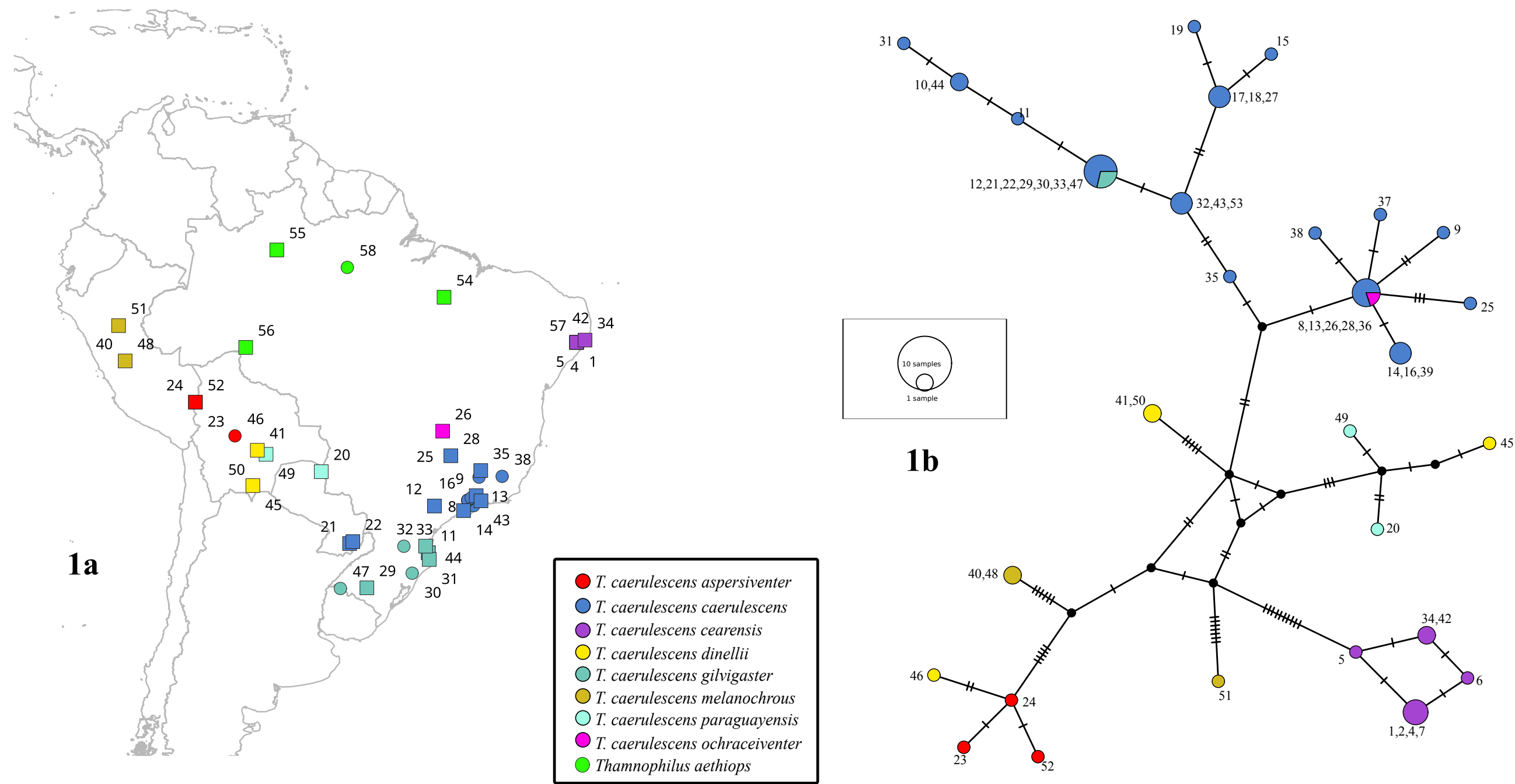

Figure 1. (a) Map showing the samples collected of T. caerulescens (codes of samples in Table S1.).

(b) median-joining network depicting relationships among the haplotypes in T. caerulescens. 

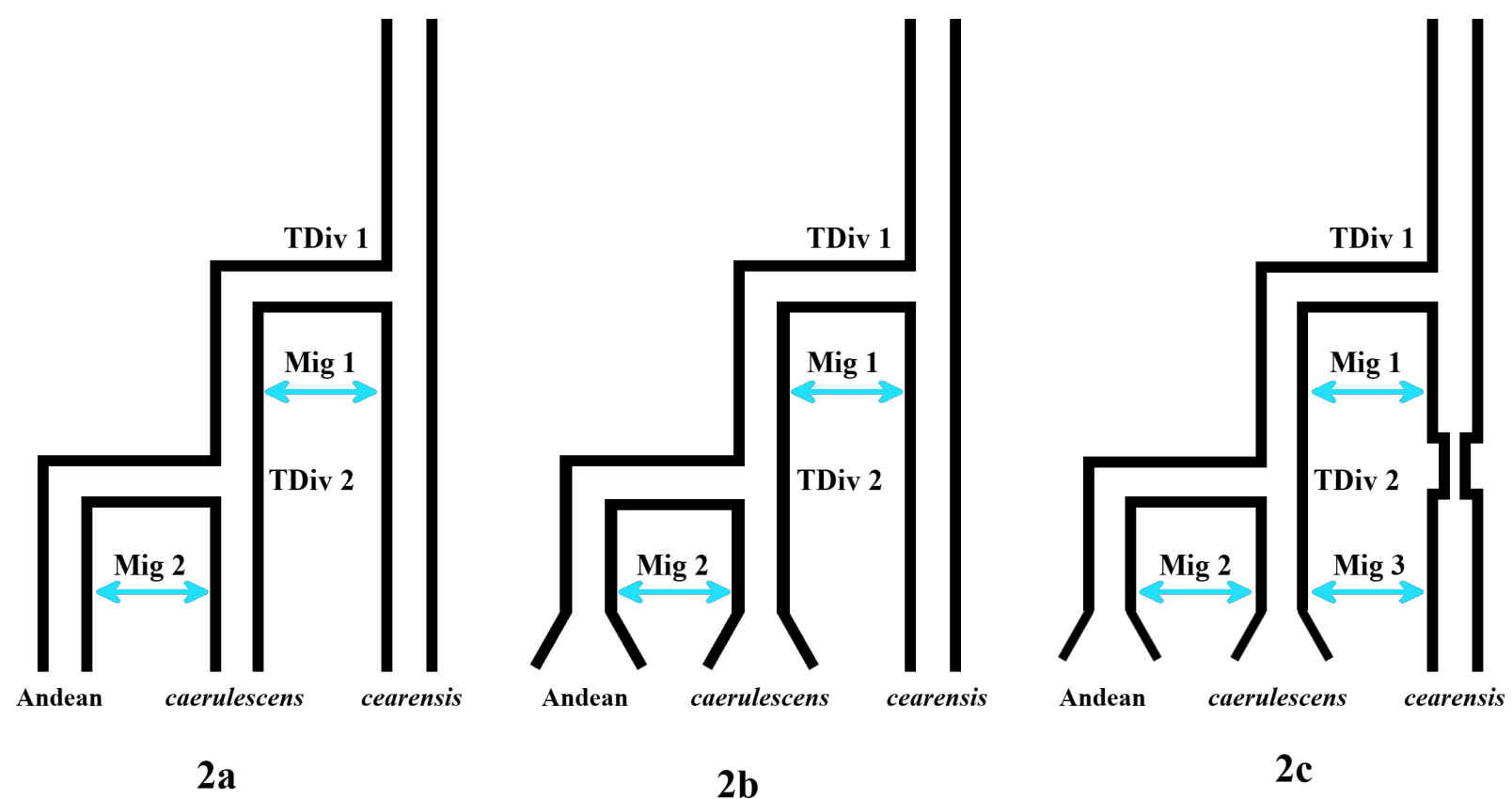

Figure 2. Demographic models tested in momi2 for the clusters identified for T. caerulescens. 


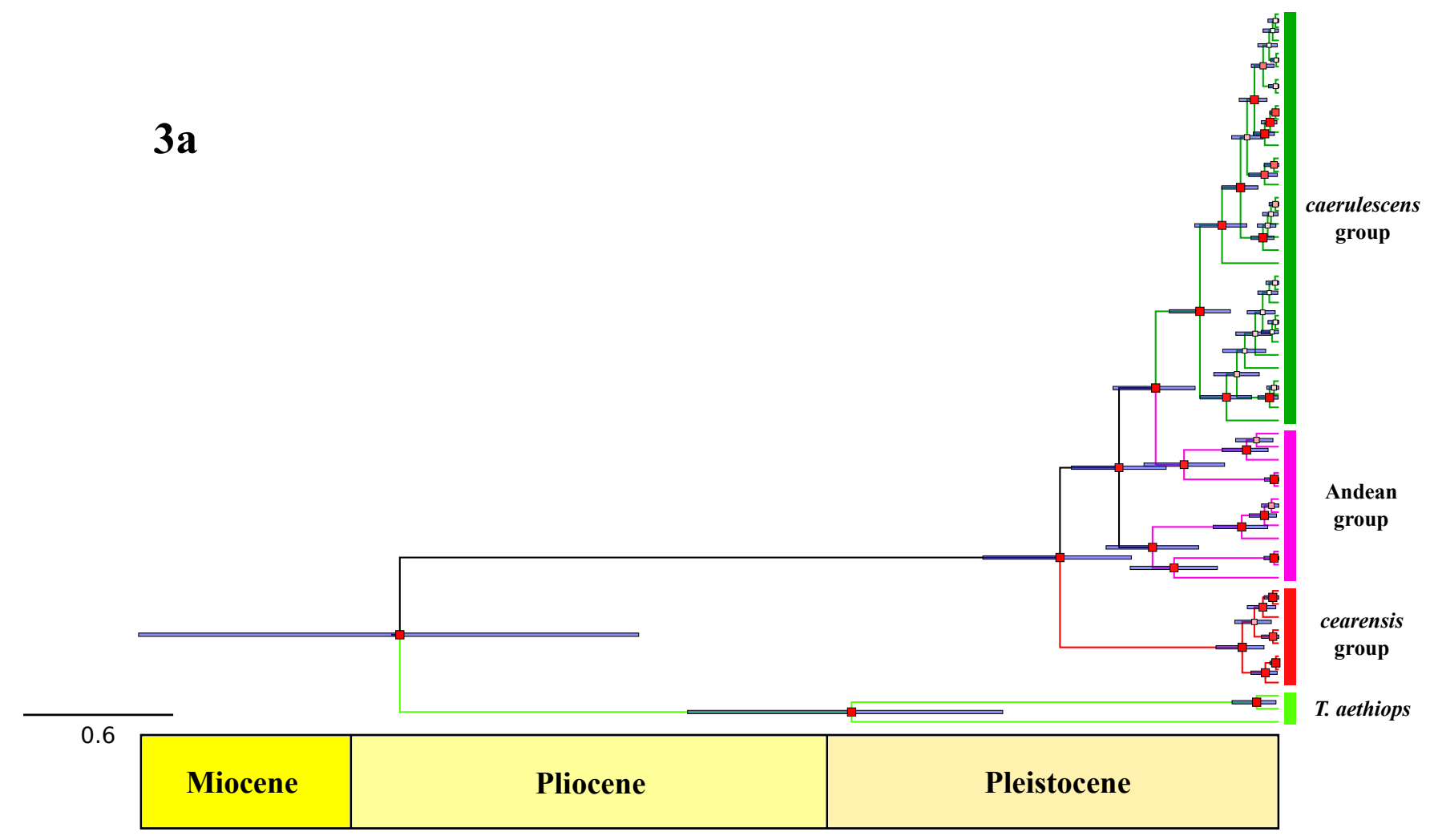

3b
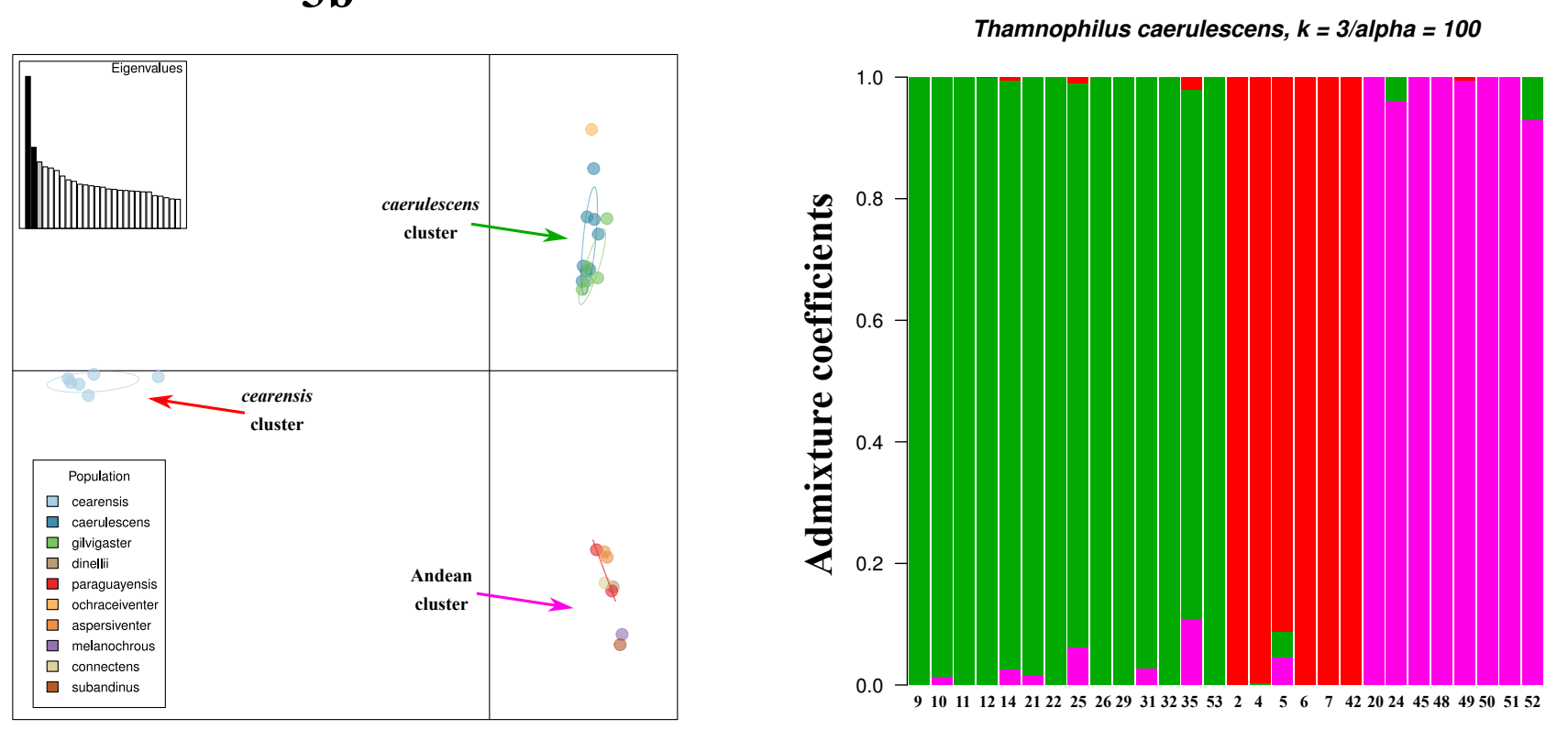

Samples

Figure 3. (a) Bayesian reconstruction and divergence times for T. caerulescens. (b) Clusters identified by DAPC in T. caerulescens. (c) Graphical representation of admixture estimates of three clusters in T. caerulescens. Estimated admixture coefficients using sNMF using $\mathrm{K}=3$ and alpha $=100$ (cross-entropy $=0,379352)$. 
$4 a$

T. aethiops

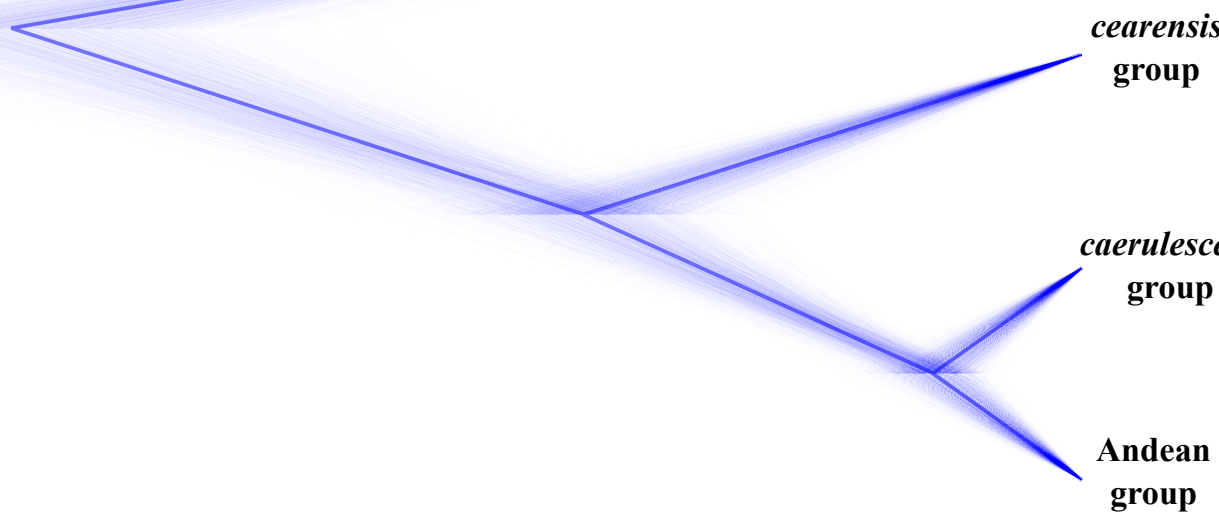

$4 b$

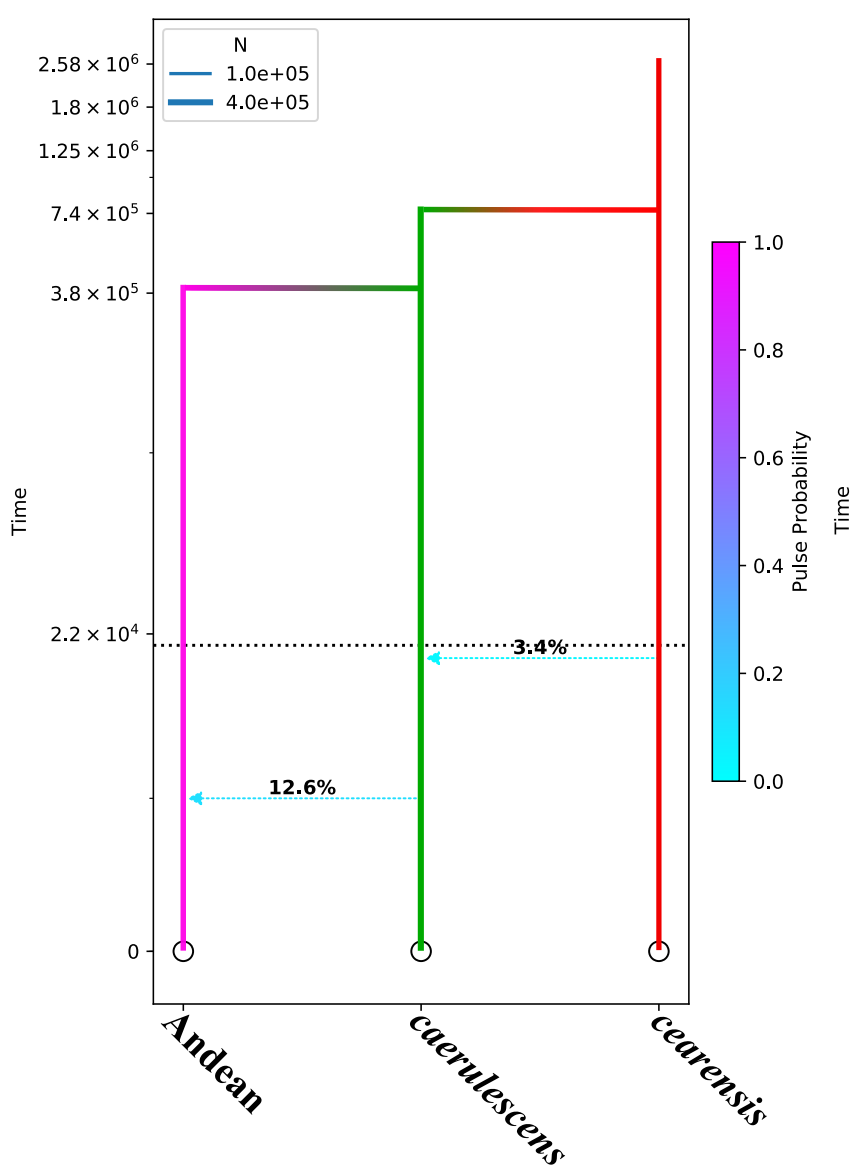

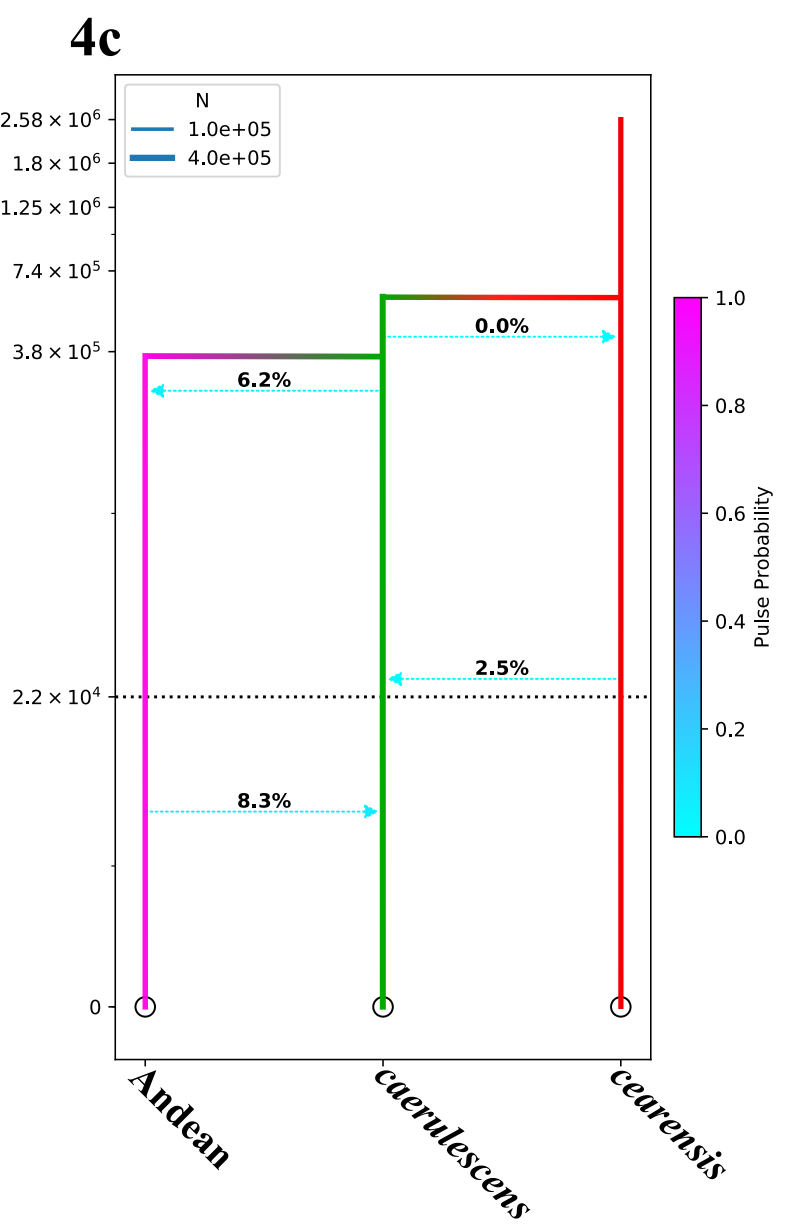

Figure 4. (a) Species trees inferred by SNAPP for the T. caerulescens data. (b) Demographic reconstruction with the best model for the complete matrix of SNPs (324 loci). (c) Demographic reconstruction with the best model for the incomplete matrix of SNPs (2,036 loci). 

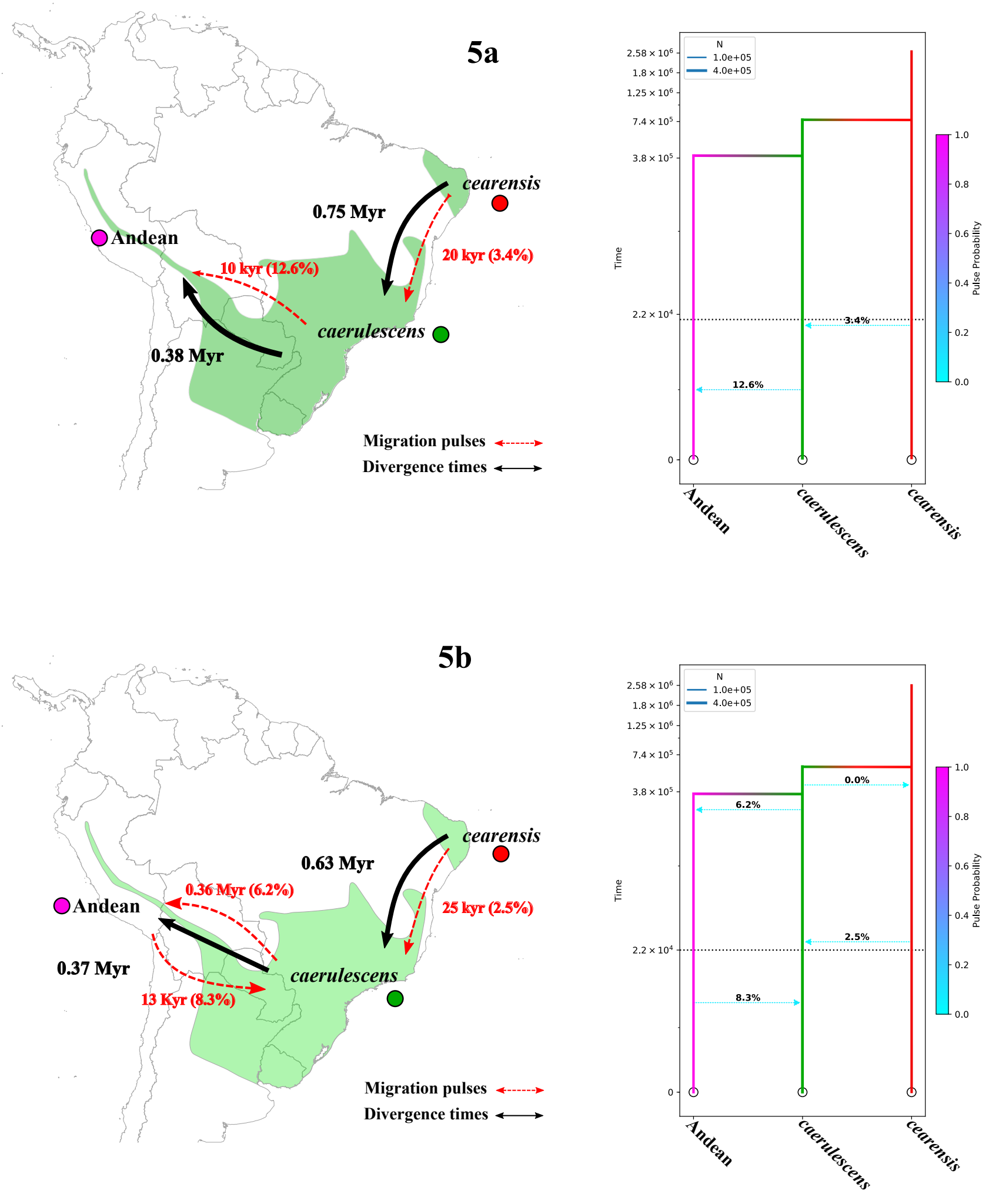

Figure 5. Plausible scenarios of diversification of $T$. caerulescens, with the migration pulses inferred by momi2. (a) Best model in the complete matrix of SNPs (324 loci). (b) Best model in the incomplete matrix of SNPs (2,036 loci). 

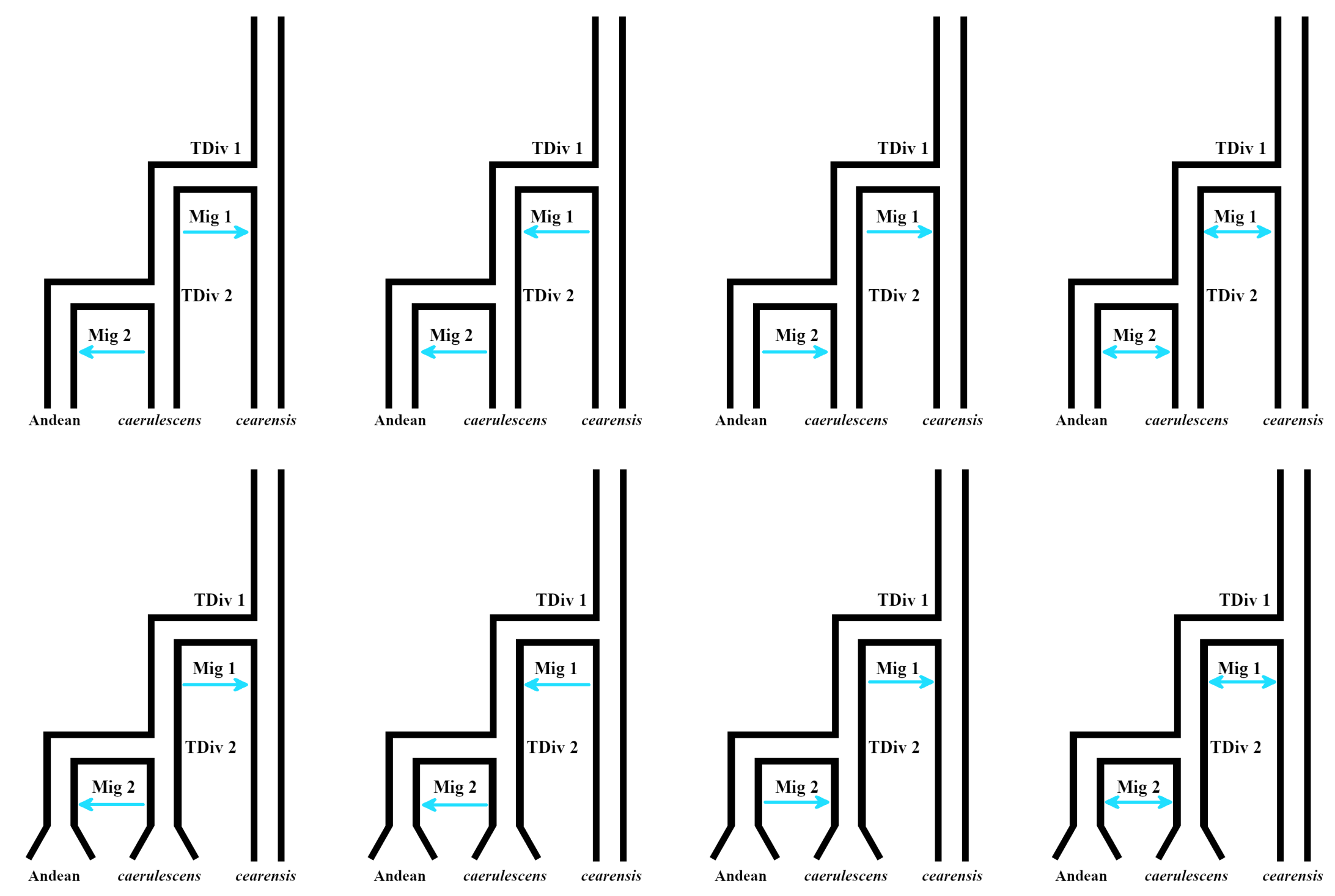

Figure S1a. Graphical representation of all models tested in momi2 (part 1). 

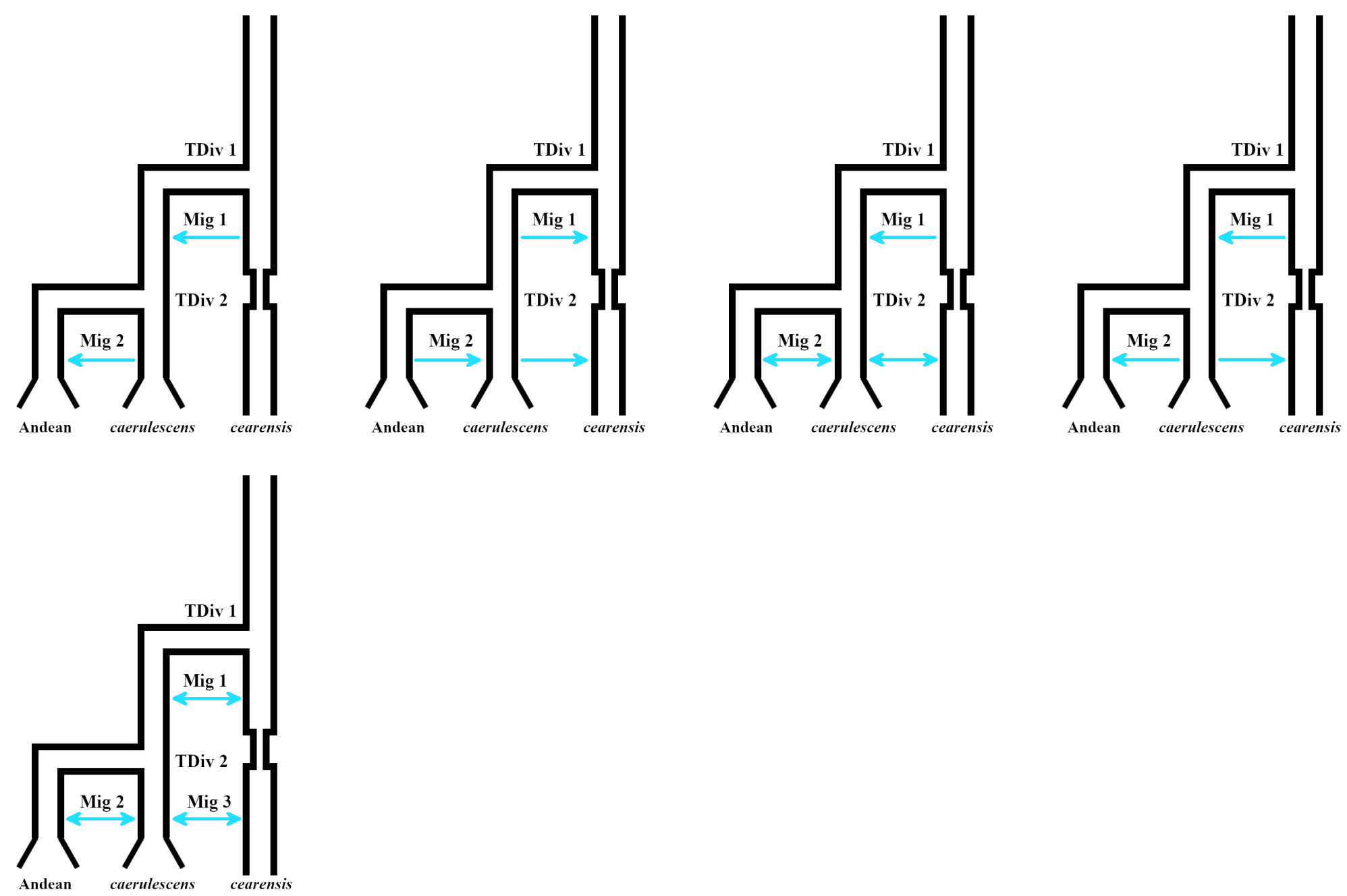

Figure S1b. Graphical representation of all models tested in momi2 (part 2). 


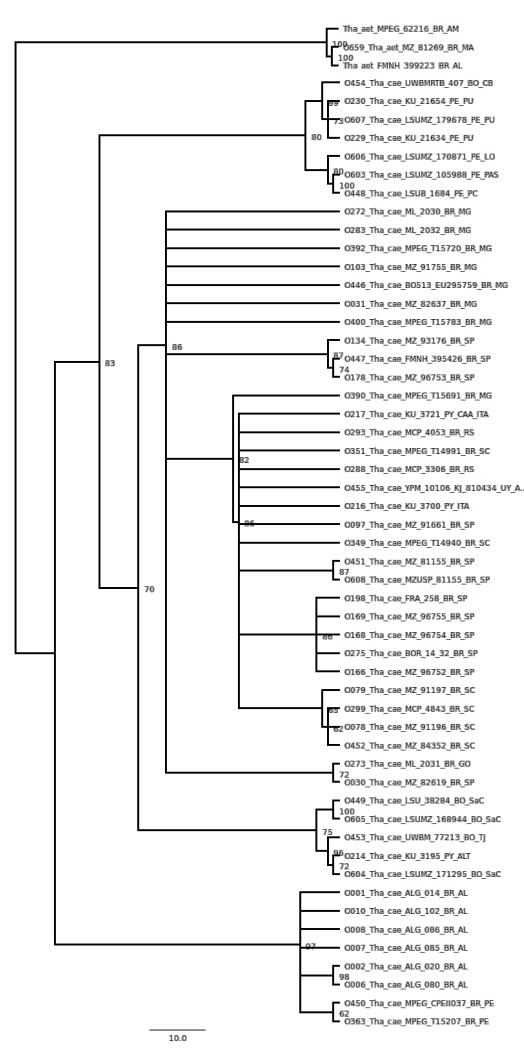

$\mathbf{s} \mathbf{2 b}$
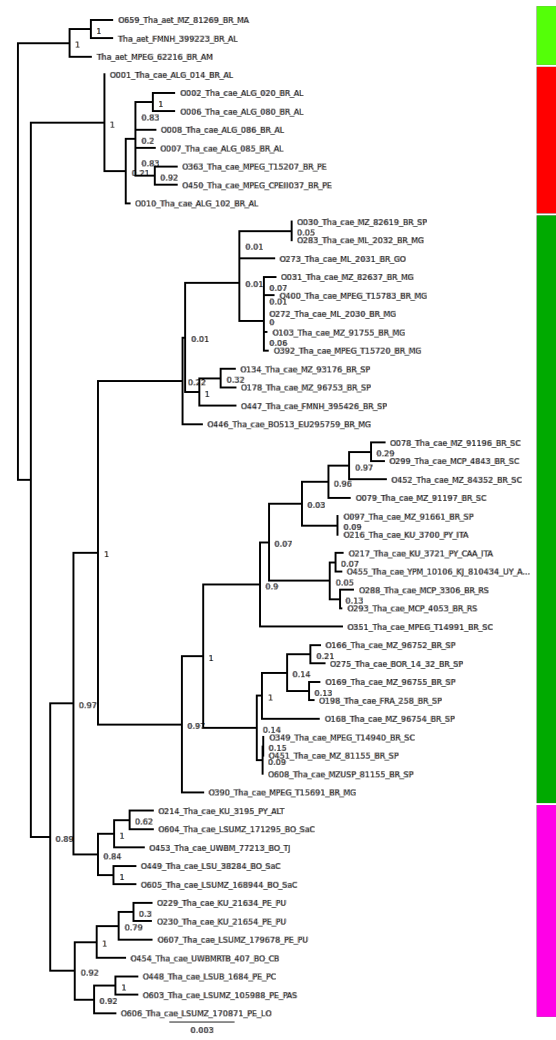

$\mathbf{s 2 b}$

Figure S2. Topologies reconstructed for the mtDNA data of $T$. caerulescens. (a) Maximum Likelihood in RAxML. (b) Bayesian inference with BEAST. 


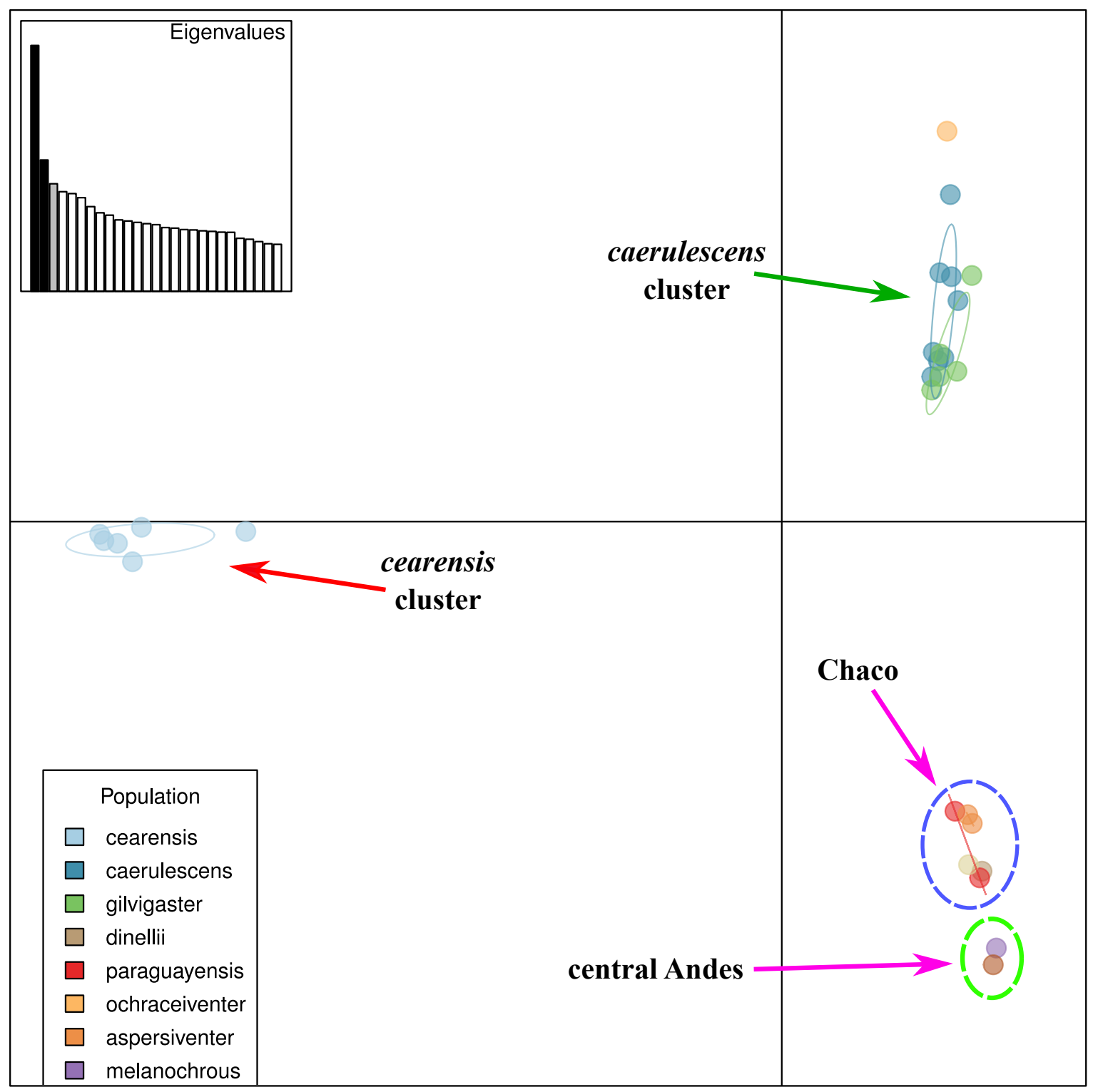

Figure S3. Clusters identified with the incomplete matrix for $T$. caerulescens. The central Andean samples can be separated in a southern Peru-Bolivia and a central Peru subgroups. 


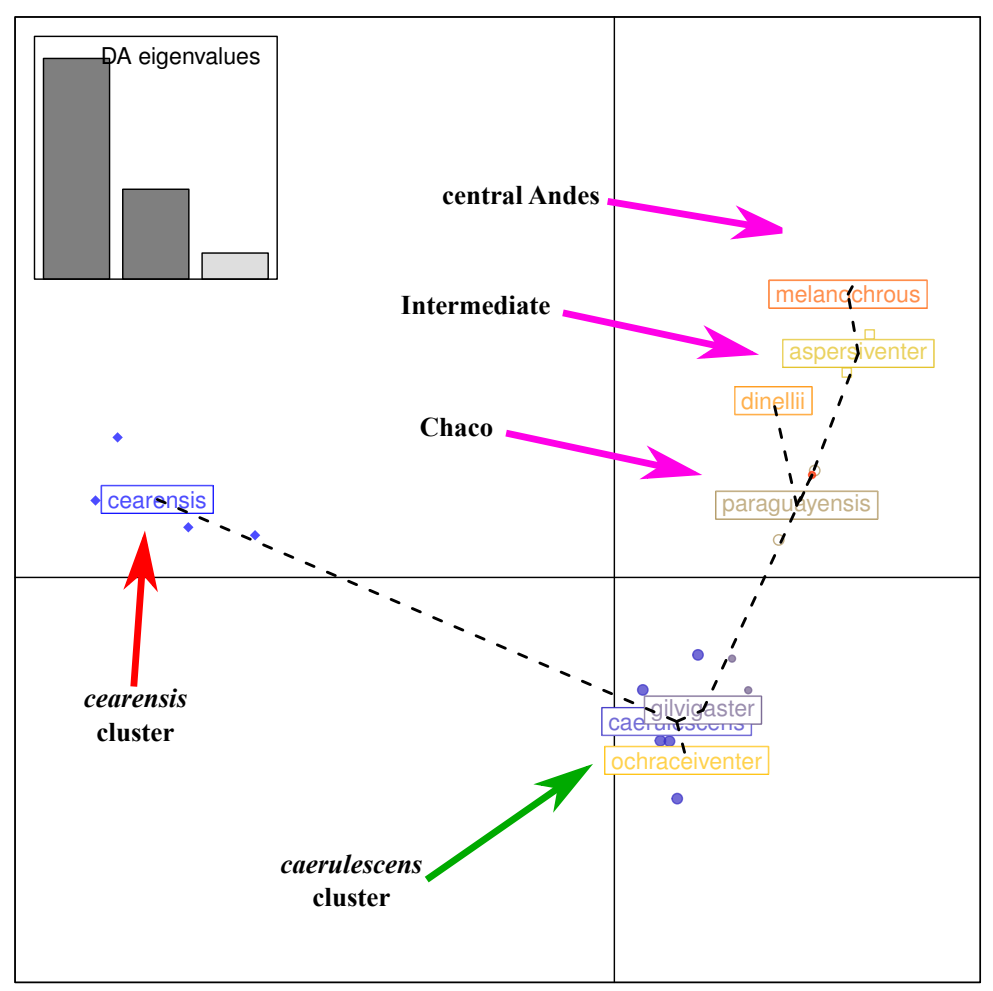

S4a

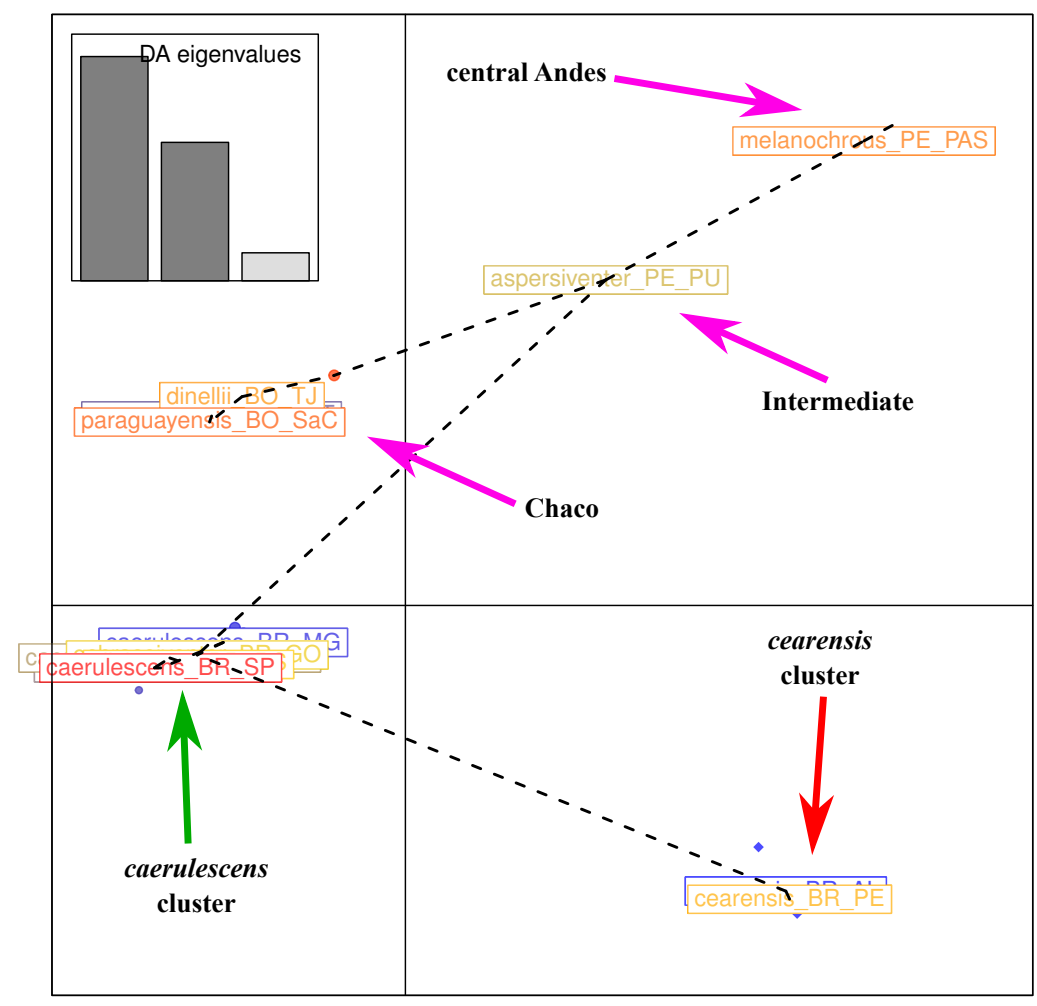

S4b

Figure S4. DAPC depicting a clinal pattern in the central Andean samples of $T$. caerulescens. (a) Complete matrix. (b) Incomplete matrix. 

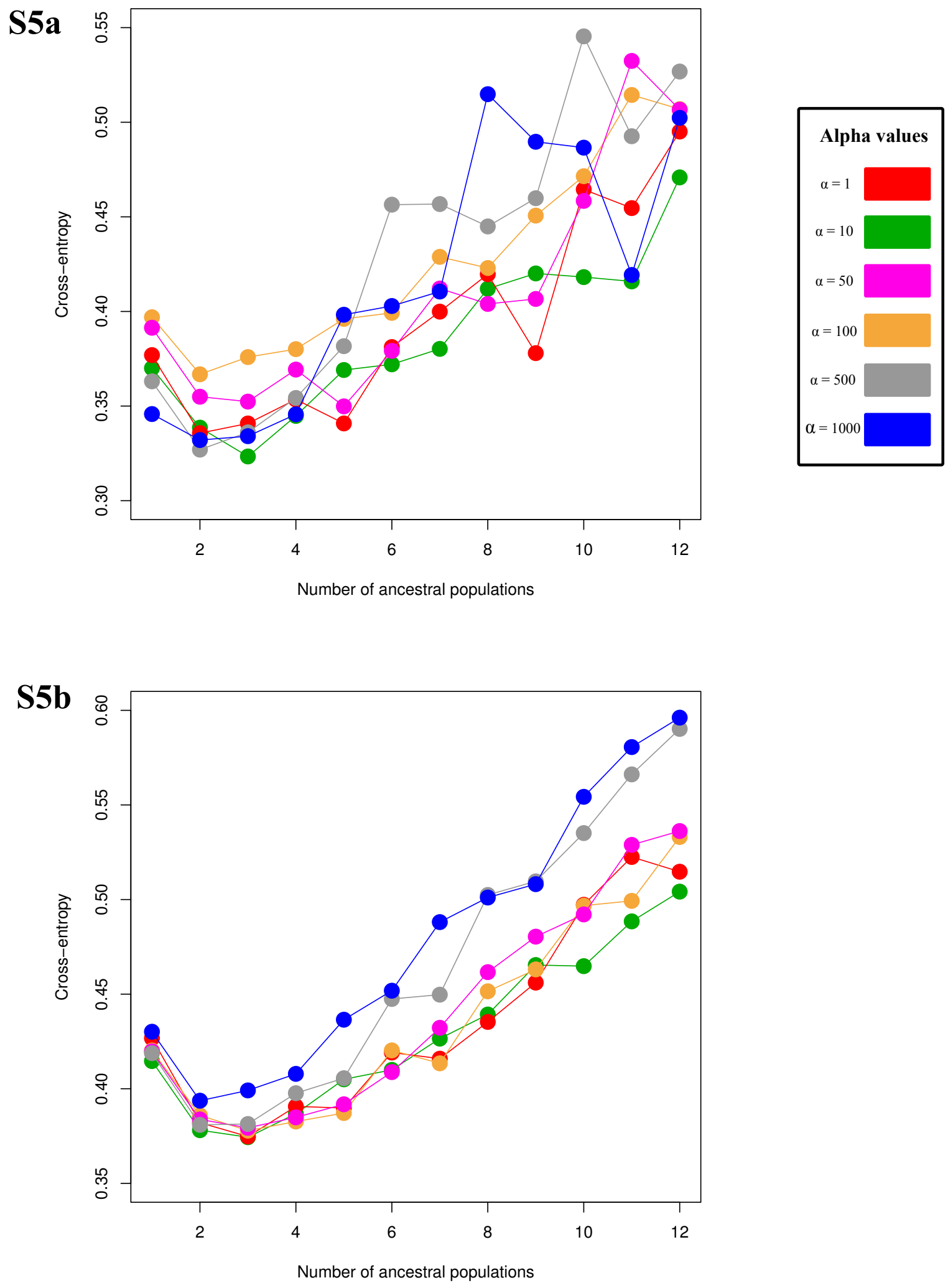

Figure S5. Values of cross-entropy for six values of $\boldsymbol{\alpha}(1,10,50,100$, 500, 1000). (a) Complete matrix. (b) Incomplete matrix. 
Table 1. List of tested models for the complete matrix in T. caerulescens.

\begin{tabular}{|c|c|c|c|c|c|}
\hline Model number & Log likelihood & $\begin{array}{c}\text { Number parameters } \\
\text { model }\end{array}$ & AICs & Delta AIC & Weight AICs \\
\hline Model 1 & -1258.51153 & 2 & 2521.023061 & 44.1059732 & $2.65 \mathrm{E}-10$ \\
\hline Model 2 & -1249.760663 & 5 & 2509.521326 & 32.60423837 & $8.32 \mathrm{E}-08$ \\
\hline Model 3 & -1252.647448 & 5 & 2515.294896 & 38.37780816 & $4.64 \mathrm{E}-09$ \\
\hline Model 4* & $\mathbf{- 1 2 2 9 . 4 5 8 5 4 4}$ & $\mathbf{9}$ & $\mathbf{2 4 7 6 . 9 1 7 0 8 8}$ & $\mathbf{0}$ & $\mathbf{1}$ \\
\hline Model 5 & -1240.297117 & 9 & 2498.594234 & 21.67714629 & $1.96 \mathrm{E}-05$ \\
\hline Model 6 & -1235.112871 & 9 & 2488.225743 & 11.30865505 & 0.003502328 \\
\hline Model 7 & -1225.937369 & 13 & 2477.874737 & 0.957649748 & 0.619510968 \\
\hline Model 8 & -1252.889427 & 11 & 2527.778853 & 50.86176583 & $9.03 \mathrm{E}-12$ \\
\hline Model 9 & -1266.947654 & 11 & 2555.895309 & 78.97822097 & $7.08 \mathrm{E}-18$ \\
\hline Model 10 & -1243.957441 & 16 & 2519.914881 & 42.99779359 & $4.60 \mathrm{E}-10$ \\
\hline Model 11 & -1247.822782 & 16 & 2527.645565 & 50.72847734 & $9.65 \mathrm{E}-12$ \\
\hline Model 12 & -1273.973514 & 11 & 2569.947027 & 93.02993993 & $6.29 \mathrm{E}-21$ \\
\hline Model 13 & -1255.509493 & 16 & 2543.018986 & 66.10189838 & $4.43 \mathrm{E}-15$ \\
\hline Model 14 & -1284.761711 & 11 & 2591.523422 & 114.6063348 & $1.30 \mathrm{E}-25$ \\
\hline Model 15 & -1293.999998 & 11 & 2609.732288 & 132.8152009 & $1.44 \mathrm{E}-29$ \\
\hline Model 16 & -1293.866144 & 11 & 2609.732288 & 132.8152009 & $1.44 \mathrm{E}-29$ \\
\hline
\end{tabular}

* Chosen model.

Table 2. List of tested models for the incomplete matrix in T. caerulescens.

\begin{tabular}{|c|c|c|c|c|c|}
\hline Model number & Log likelihood & Number parameters model & AICs & Delta AIC & Weight AICs \\
\hline Model 1 & -7481.577811 & 2 & 14967.15562 & 392.1354344 & $7.06 \mathrm{E}-86$ \\
\hline Model 2 & -7383.252541 & 5 & 14776.50508 & 201.4848944 & $1.77 \mathrm{E}-44$ \\
\hline Model 3 & -7386.643388 & 5 & 14783.28678 & 208.2665891 & $5.96 \mathrm{E}-46$ \\
\hline Model 4 & -7323.523233 & 9 & 14665.04647 & 90.02627891 & $2.83 \mathrm{E}-20$ \\
\hline Model 5 & -7345.247239 & 9 & 14708.49448 & 133.4742895 & $1.04 \mathrm{E}-29$ \\
\hline Model 6 & -7299.864124 & 9 & 14617.72825 & 42.70805956 & $5.32 \mathrm{E}-10$ \\
\hline Model 7* & -7274.510094 & 13 & $\mathbf{1 4 5 7 5 . 0 2 0 1 9}$ & $\mathbf{0}$ & 1 \\
\hline Model 8 & -7574.598842 & 11 & 15171.19768 & 596.1774969 & $3.48 \mathrm{E}-130$ \\
\hline Model 9 & -7528.523218 & 11 & 15079.04644 & 504.026249 & $3.57 \mathrm{E}-110$ \\
\hline Model 10 & -7388.482618 & 16 & 14808.96524 & 233.9450474 & $1.58 \mathrm{E}-51$ \\
\hline Model 11 & -7394.500327 & 16 & 14821.00065 & 245.9804667 & $3.85 \mathrm{E}-54$ \\
\hline Model 12 & -7522.21469 & 11 & 15066.42938 & 491.4091924 & $1.96 \mathrm{E}-107$ \\
\hline Model 13 & -7394.482314 & 16 & 14820.96463 & 245.9444395 & $3.93 \mathrm{E}-54$ \\
\hline Model 14 & -7807.853685 & 11 & 15637.70737 & 1062.687182 & $1.74 \mathrm{E}-231$ \\
\hline Model 15 & -7621.885811 & 19 & 15281.77162 & 706.7514342 & $3.40 \mathrm{E}-154$ \\
\hline Model 16 & -7724.954811 & 11 & 15471.90962 & 896.8894352 & $1.75 \mathrm{E}-195$ \\
\hline
\end{tabular}


Table S1. Samples collected of T. caerulescens for this study.

\begin{tabular}{|c|c|c|c|c|c|c|}
\hline $\begin{array}{l}\text { Code in } \\
\text { Graphics }\end{array}$ & Voucher & Taxon & State & $\begin{array}{c}\text { Count } \\
\text { ry }\end{array}$ & Locality & UCEs \\
\hline 1 & ALG-014 & Thamnophilus caerulescens & Alagoas & Brazil & AL, São José da Lage, Usina Serra Grande & \\
\hline 2 & ALG-020 & Thamnophilus caerulescens & Alagoas & Brazil & AL, São José da Lage, Usina Serra Grande & YES \\
\hline 3 & ALG-053 & Thamnophilus caerulescens & Alagoas & Brazil & AL, São José da Lage, Usina Serra Grande & \\
\hline 4 & ALG-080 & Thamnophilus caerulescens & Alagoas & Brazil & AL, São José da Lage, Usina Serra Grande & YES \\
\hline 5 & ALG-085 & Thamnophilus caerulescens & Alagoas & Brazil & AL, São José da Lage, Usina Serra Grande & YES \\
\hline 6 & ALG-086 & Thamnophilus caerulescens & Alagoas & Brazil & AL, São José da Lage, Usina Serra Grande & YES \\
\hline 7 & ALG-102 & Thamnophilus caerulescens & Alagoas & Brazil & AL, São José da Lage, Usina Serra Grande & YES \\
\hline 8 & MZ 82619 & $\begin{array}{c}\text { Thamnophilus caerulescens } \\
\text { caerulescens }\end{array}$ & São Paulo & Brazil & Cunha, estrada para o Parque Estadual & \\
\hline 9 & MZ 82637 & $\begin{array}{c}\text { Thamnophilus caerulescens } \\
\text { caerulescens }\end{array}$ & $\begin{array}{l}\text { Minas } \\
\text { Gerais } \\
\end{array}$ & Brazil & Itamonte & YES \\
\hline 10 & MZ 91196 & $\begin{array}{c}\text { Thamnophilus caerulescens } \\
\text { gilvigaster }\end{array}$ & $\begin{array}{c}\text { Santa } \\
\text { Catarina }\end{array}$ & Brazil & Nova Trento & YES \\
\hline 11 & MZ 91197 & $\begin{array}{c}\text { Thamnophilus caerulescens } \\
\text { gilvigaster }\end{array}$ & $\begin{array}{c}\text { Santa } \\
\text { Catarina }\end{array}$ & Brazil & Nova Trento & YES \\
\hline 12 & MZ 91661 & $\begin{array}{c}\text { Thamnophilus caerulescens } \\
\text { caerulescens }\end{array}$ & São Paulo & Brazil & Angatuba, Fazenda Entre Rios & YES \\
\hline 13 & MZ 91755 & $\begin{array}{c}\text { Thamnophilus caerulescens } \\
\text { caerulescens }\end{array}$ & $\begin{array}{l}\text { Minas } \\
\text { Gerais } \\
\end{array}$ & Brazil & Passa Tempo, Fazenda Ribeirão das Cachoeiras & \\
\hline 14 & MZ 93176 & $\begin{array}{c}\text { Thamnophilus caerulescens } \\
\text { caerulescens }\end{array}$ & São Paulo & Brazil & Estação Biológica de Boracéia, Salesópolis & YES \\
\hline 15 & MZ 96752 & $\begin{array}{c}\text { Thamnophilus caerulescens } \\
\text { caerulescens }\end{array}$ & São Paulo & Brazil & Campos do Jordão, Fazenda Prana & \\
\hline 16 & MZ 96753 & $\begin{array}{c}\text { Thamnophilus caerulescens } \\
\text { caerulescens }\end{array}$ & São Paulo & Brazil & Campos do Jordão, Fazenda Prana & \\
\hline 17 & MZ 96754 & $\begin{array}{c}\text { Thamnophilus caerulescens } \\
\text { caerulescens }\end{array}$ & São Paulo & Brazil & Campos do Jordão, Fazenda Prana & \\
\hline 18 & MZ 96755 & $\begin{array}{c}\text { Thamnophilus caerulescens } \\
\text { caerulescens }\end{array}$ & São Paulo & Brazil & Campos do Jordão, Fazenda Prana & \\
\hline 19 & FRA 258* & Thamnophilus caerulescens & São Paulo & Brazil & Delfim Moreira (8 Km SE) & \\
\hline
\end{tabular}




\begin{tabular}{|c|c|c|c|c|c|c|}
\hline $\begin{array}{c}\text { Code in } \\
\text { Graphics }\end{array}$ & Voucher & Taxon & State & $\begin{array}{c}\text { Count } \\
\text { ry }\end{array}$ & Locality & UCEs \\
\hline 20 & KU 3195 & Thamnophilus caerulescens & $\begin{array}{c}\text { Alto } \\
\text { Paraguay } \\
\end{array}$ & $\begin{array}{c}\text { Parag } \\
\text { uay }\end{array}$ & Bahia Negra, 14 km W, Estancia Triunfo & YES \\
\hline 21 & KU 3700 & Thamnophilus caerulescens & Itapua & $\begin{array}{c}\text { Parag } \\
\text { uay }\end{array}$ & San Rafael N.P., San Pedro Mi & YES \\
\hline 22 & KU 3721 & Thamnophilus caerulescens & $\begin{array}{l}\text { Caazapa/Ita } \\
\text { pua }\end{array}$ & $\begin{array}{l}\text { Parag } \\
\text { uay }\end{array}$ & San Rafael N.P., Parabel & YES \\
\hline 23 & KU 21634 & Thamnophilus caerulescens & Puno & Peru & above San Juan del Oro & \\
\hline 24 & KU 21654 & Thamnophilus caerulescens & Puno & Peru & above San Juan del Oro & YES \\
\hline 25 & ML 2030* & Thamnophilus caerulescens & $\begin{array}{l}\text { Minas } \\
\text { Gerais }\end{array}$ & Brazil & Patrocinio & YES \\
\hline 26 & ML 2031* & Thamnophilus caerulescens & Goiás & Brazil & Cristalina & YES \\
\hline 27 & BOR-14-32 & Thamnophilus caerulescens & São Paulo & Brazil & Estação Biológica de Boracéia & \\
\hline 28 & ML 2032* & Thamnophilus caerulescens & $\begin{array}{l}\text { Minas } \\
\text { Gerais } \\
\end{array}$ & Brazil & Patrocinio & \\
\hline 29 & MCP 3306 & Thamnophilus caerulescens & $\begin{array}{l}\text { Rio Grande } \\
\text { do Sul }\end{array}$ & Brazil & São Gabriel & YES \\
\hline 30 & MCP 4053 & Thamnophilus caerulescens & $\begin{array}{c}\text { Rio Grande } \\
\text { do Sul }\end{array}$ & Brazil & Jaquirana & \\
\hline 31 & MCP 4843 & Thamnophilus caerulescens & $\begin{array}{c}\text { Santa } \\
\text { Catarina } \\
\end{array}$ & Brazil & São Bonifácio & YES \\
\hline 32 & MPEG T14940 & Thamnophilus caerulescens & $\begin{array}{c}\text { Santa } \\
\text { Catarina }\end{array}$ & Brazil & Pomerode, Morro da Turquia & YES \\
\hline 33 & MPEG T14991 & Thamnophilus caerulescens & $\begin{array}{c}\text { Santa } \\
\text { Catarina } \\
\end{array}$ & Brazil & Caçador, Linha São Francisco & \\
\hline 34 & MPEG T15207 & Thamnophilus caerulescens & Pernambuco & Brazil & Barreiros, Engenho Cachoeira Linda (08o48'S;35o19'W) & \\
\hline 35 & MPEG T15691 & Thamnophilus caerulescens & $\begin{array}{l}\text { Minas } \\
\text { Gerais } \\
\end{array}$ & Brazil & $\begin{array}{l}\text { Fazenda Princesa da Serra, Córrego do Mota, Serra Azul, } \\
\text { Itatiaiuçu }\end{array}$ & YES \\
\hline 36 & MPEG T15720 & Thamnophilus caerulescens & $\begin{array}{l}\text { Minas } \\
\text { Gerais }\end{array}$ & Brazil & Barragem de rejeito da USIMINAS, Serra Azul, Itatiaiuçu & \\
\hline 37 & MPEG T15783 & Thamnophilus caerulescens & $\begin{array}{l}\text { Minas } \\
\text { Gerais }\end{array}$ & Brazil & Barragem de rejeito da USIMINAS, Serra Azul, Itatiaiuçu & \\
\hline 38 & $\begin{array}{c}\text { BO513 } \\
\text { EU295759** }\end{array}$ & Thamnophilus caerulescens & $\begin{array}{l}\text { Minas } \\
\text { Gerais }\end{array}$ & Brazil & Araponga & \\
\hline 39 & FMNH 395426 & Thamnophilus caerulescens & São Paulo & Brazil & Boraceia & \\
\hline 40 & LSUB 1684 & Thamnophilus caerulescens & Pasco & Peru & Santa Cruz; about 9 km SSE Oxapampa & \\
\hline
\end{tabular}




\begin{tabular}{|c|c|c|c|c|c|c|}
\hline $\begin{array}{l}\text { Code in } \\
\text { Graphics }\end{array}$ & Voucher & Taxon & State & $\begin{array}{c}\text { Count } \\
\text { ry }\end{array}$ & Locality & UCEs \\
\hline 41 & LSU 38284 & Thamnophilus caerulescens & Santa Cruz & $\begin{array}{c}\text { Bolivi } \\
\text { a }\end{array}$ & La Pajcha, 28 km S Samaipata; & \\
\hline 42 & $\begin{array}{c}\text { MPEG } \\
\text { CPEII037 }\end{array}$ & Thamnophilus caerulescens & Pernambuco & Brazil & Barreiros, Engenho Cachoeira Linda (08o48'S;35o19'W) & YES \\
\hline 43 & MZ 81155 & Thamnophilus caerulescens & São Paulo & Brazil & E. E. Bananal, Bananal & \\
\hline 44 & MZ 84352 & Thamnophilus caerulescens & $\begin{array}{c}\text { Santa } \\
\text { Catarina }\end{array}$ & Brazil & SC-407, Rancho Queimado & \\
\hline 45 & UWBM 77213 & Thamnophilus caerulescens & Tarija & $\begin{array}{c}\text { Bolivi } \\
\text { a }\end{array}$ & Entre Rios, O'connor & YES \\
\hline 46 & UWBMRTB 407 & Thamnophilus caerulescens & $\begin{array}{l}\text { Cochabamb } \\
\text { a }\end{array}$ & $\begin{array}{c}\text { Bolivi } \\
\text { a }\end{array}$ & Provincia de Chapare, San Onofre & \\
\hline 47 & $\begin{array}{l}\text { YPM } 10106 \mathrm{KJ} \\
810434\end{array}$ & Thamnophilus caerulescens & Artigas & $\begin{array}{c}\text { Argen } \\
\text { tina }\end{array}$ & Artigas & \\
\hline 48 & LSUMZ 105988 & $\begin{array}{c}\text { Thamnophilus caerulescens } \\
\text { melanochrous }\end{array}$ & Pasco & Peru & Santa Cruz; about 9 km SSE Oxapampa & YES \\
\hline 49 & LSUMZ 171295 & $\begin{array}{c}\text { Thamnophilus caerulescens } \\
\text { paraguayensis }\end{array}$ & Santa Cruz & $\begin{array}{c}\text { Bolivi } \\
\text { a }\end{array}$ & $\begin{array}{l}\text { Santa Cruz, Prov. Cordillera, } 38.4 \text { km E Abapo, } 18 \text { degrees } \\
\text { 44' 48" S, } 63 \text { degrees 04' 06" W }\end{array}$ & YES \\
\hline 50 & LSUMZ 168944 & $\begin{array}{l}\text { Thamnophilus caerulescens } \\
\text { connectens }\end{array}$ & Santa Cruz & $\begin{array}{c}\text { Bolivi } \\
\text { a }\end{array}$ & Santa Cruz, La Chuchial & YES \\
\hline 51 & LSUMZ 170871 & $\begin{array}{l}\text { Thamnophilus caerulescens } \\
\text { subandinus }\end{array}$ & Loreto & Peru & Ca. 80 km SE Juanjui on E. bank upper Río Pauya & YES \\
\hline 52 & LSUMZ 179678 & $\begin{array}{l}\text { Thamnophilus caerulescens } \\
\text { aspersiventer }\end{array}$ & Puno & Peru & Abra de Maruncunea, 14 degrees $12^{\prime}$ S, 69 degrees $13^{\prime} \mathrm{W}$ & YES \\
\hline 53 & MZUSP 81155 & $\begin{array}{c}\text { Thamnophilus caerulescens } \\
\text { caerulescens }\end{array}$ & São Paulo & Brazil & E. E. de Bananal, Bananal & YES \\
\hline 54 & MZ 81269 & $\begin{array}{c}\text { Thamnophilus aethiops } \\
\text { incertus }\end{array}$ & Maranhão & Brazil & Açailândia, Fazenda Itabaiana & YES \\
\hline 55 & MZ 93741 & $\begin{array}{c}\text { Thamnophilus aethiops } \\
\text { polionotus }\end{array}$ & Roraima & Brazil & $\begin{array}{c}\text { Caracaraí, rio Jufari, Igarapé Caicubi, Trilha Paraguai, } \\
\text { Sitio do Valdir }\end{array}$ & YES \\
\hline 56 & J 1799* & $\begin{array}{l}\text { Thamnophilus aethiops } \\
\text { injunctus }\end{array}$ & Rondônia & Brazil & JIRAU, margen esquerda Rio Madeira, Caiçara T1P2 & YES \\
\hline 57 & FMNH 399223 & Thamnophilus aethiops & Alagoas & Brazil & Ibateouara, Engenho Coimbra, Usina Serra Grande & \\
\hline 58 & MPEG 62216 & Thamnophilus aethiops & Amazonas & Brazil & Juruti, Base Capiranga & \\
\hline
\end{tabular}

* Field number

** Genebank code access 
Table S2. Cross-entropy values for $T$. caerulescens $(\boldsymbol{\alpha}=1,10,50,100,500,1000)$.

\begin{tabular}{|c|c|c|c|c|c|c|c|c|c|c|c|c|c|c|c|}
\hline Alpha=1 & $K=1$ & $K=2$ & $K=3$ & $K=4$ & $K=5$ & $K=6$ & $K=7$ & $K=8$ & $K=9$ & $K=10$ & $K=11$ & $K=12$ & lowest & 2d. lowest & Difference \\
\hline $\min$ & 0.41463 & 0.37810 & 0.37439 & 0.38679 & 0.40498 & 0.40998 & 0.42651 & 0.43924 & 0.46538 & 0.46480 & 0.488458 & 0.5041613 & 0.37439 & 0.37810 & 0.00370 \\
\hline mean & 0.46818 & 0.43040 & 0.42527 & 0.43747 & 0.45027 & 0.46680 & 0.48686 & 0.50796 & 0.52824 & 0.54831 & 0.5722283 & 0.5980912 & 0.42527 & 0.43040 & 0.00513 \\
\hline $\max$ & 0.51230 & 0.47448 & 0.47385 & 0.49359 & 0.50404 & 0.52809 & 0.56818 & 0.57198 & 0.62220 & 0.63828 & 0.660845 & 0.6886311 & 0.47385 & 0.47448 & 0.00063 \\
\hline Alpha $=10$ & $K=1$ & $K=2$ & $\mathrm{~K}=\mathbf{3}$ & $K=4$ & $K=5$ & $K=6$ & $K=7$ & $K=8$ & $K=9$ & $K=10$ & $K=11$ & $K=12$ & lowest & 2d. lowest & Difference \\
\hline $\min$ & 0.42668 & 0.38206 & 0.37474 & 0.39066 & 0.38981 & 0.41915 & 0.41590 & 0.43532 & 0.45610 & 0.49724 & 0.5225096 & 0.5146925 & 0.37474 & 0.38206 & 0.00732 \\
\hline mean & 0.46730 & 0.42947 & 0.42333 & 0.43588 & 0.44978 & 0.46952 & 0.48733 & 0.50797 & 0.53013 & 0.54987 & 0.5744045 & 0.5983819 & 0.42333 & 0.42947 & 0.00614 \\
\hline $\max$ & 0.51302 & 0.47696 & 0.50495 & 0.50696 & 0.51499 & 0.53598 & 0.53778 & 0.57670 & 0.62257 & 0.63576 & 0.7052284 & 0.6887136 & 0.47696 & 0.50495 & 0.02799 \\
\hline Alpha $=50$ & $K=1$ & $K=2$ & $K=3$ & $K=4$ & $K=5$ & $K=6$ & $K=7$ & $K=8$ & $K=9$ & $K=10$ & $K=11$ & $K=12$ & lowest & 2d. lowest & Difference \\
\hline $\min$ & 0.42023 & 0.38590 & 0.37785 & 0.38267 & 0.38716 & 0.42027 & 0.41344 & 0.45151 & 0.46307 & 0.49679 & 0.4992932 & 0.5330865 & 0.37785 & 0.38267 & 0.00482 \\
\hline mean & 0.46999 & 0.43371 & 0.42788 & 0.44203 & 0.45580 & 0.47623 & 0.49685 & 0.51848 & 0.53777 & 0.56201 & 0.5846736 & 0.6082007 & 0.42788 & 0.43371 & 0.00583 \\
\hline $\max$ & 0.51047 & 0.46892 & 0.49179 & 0.49246 & 0.52463 & 0.53898 & 0.54475 & 0.59322 & 0.59113 & 0.65335 & 0.6883291 & 0.7150304 & 0.46892 & 0.49179 & 0.02287 \\
\hline Alpha $=100$ & $K=1$ & $K=2$ & $K=3$ & $K=4$ & $K=5$ & $K=6$ & $K=7$ & $K=8$ & $K=9$ & $K=10$ & $K=11$ & $K=12$ & lowest & 2d. lowest & Difference \\
\hline $\min$ & 0.41976 & 0.38379 & 0.37935 & 0.38487 & 0.39180 & 0.40879 & 0.43221 & 0.46163 & 0.48039 & 0.49214 & 0.5288857 & 0.5362145 & 0.37935 & 0.38379 & 0.00443 \\
\hline mean & 0.46993 & 0.43360 & 0.42808 & 0.44140 & 0.45668 & 0.47602 & 0.49718 & 0.52316 & 0.53976 & 0.56591 & 0.5922528 & 0.6147111 & 0.42808 & 0.43360 & 0.00552 \\
\hline $\max$ & 0.51528 & 0.48304 & 0.48267 & 0.50933 & 0.50896 & 0.54028 & 0.55194 & 0.59271 & 0.62097 & 0.65933 & 0.7248343 & 0.6998336 & 0.48267 & 0.48304 & 0.00037 \\
\hline Alpha $=500$ & $K=1$ & $K=2$ & $K=3$ & $K=4$ & $K=5$ & $K=6$ & $K=7$ & $K=8$ & $\mathrm{~K}=9$ & $K=10$ & $K=11$ & $K=12$ & lowest & 2d. lowest & Difference \\
\hline $\min$ & 0.41880 & 0.38092 & 0.38137 & 0.39765 & 0.40557 & 0.44746 & 0.44972 & 0.50243 & 0.50964 & 0.53512 & 0.5661571 & 0.5901958 & 0.38092 & 0.38137 & 0.00045 \\
\hline mean & 0.46720 & 0.43245 & 0.43261 & 0.44980 & 0.47214 & 0.49230 & 0.52136 & 0.54960 & 0.57662 & 0.60627 & 0.6349305 & 0.6638951 & 0.43245 & 0.43261 & 0.00016 \\
\hline $\max$ & 0.53756 & 0.50182 & 0.50858 & 0.52420 & 0.54205 & 0.57109 & 0.62757 & 0.60047 & 0.65621 & 0.68353 & 0.7254975 & 0.7601563 & 0.50182 & 0.50858 & 0.00675 \\
\hline Alpha $=1000$ & $K=1$ & $K=2$ & $K=3$ & $K=4$ & $K=5$ & $K=6$ & $K=7$ & $K=8$ & $K=9$ & $K=10$ & $K=11$ & $K=12$ & lowest & 2d. lowest & Difference \\
\hline $\min$ & 0.43014 & 0.39367 & 0.39913 & 0.40786 & 0.43649 & 0.45183 & 0.48806 & 0.50107 & 0.50813 & 0.55429 & 0.5805905 & 0.596142 & 0.39367 & 0.39913 & 0.00546 \\
\hline mean & 0.46897 & 0.43501 & 0.43493 & 0.45501 & 0.47874 & 0.51062 & 0.53522 & 0.56459 & 0.59446 & 0.62411 & 0.6530534 & 0.6837274 & 0.43493 & 0.43501 & 0.00008 \\
\hline $\max$ & 0.52614 & 0.48990 & 0.48405 & 0.52469 & 0.54719 & 0.60167 & 0.60715 & 0.64636 & 0.66495 & 0.73103 & 0.7408487 & 0.7669721 & 0.48405 & 0.48990 & 0.00586 \\
\hline
\end{tabular}


Table S3. Group membership in samples of UCEs of T. caerulescens (complete matrix).

\begin{tabular}{|c|c|c|c|c|c|c|c|c|}
\hline \multirow{2}{*}{$\begin{array}{c}\text { Clusters } \\
\text { Samples/Subspecies* }\end{array}$} & \multirow{2}{*}{$\begin{array}{l}\text { cearensis } \\
\text { cearensis }\end{array}$} & \multicolumn{3}{|c|}{ caerulescens } & \multicolumn{4}{|c|}{ Andean } \\
\hline & & caerulescens & gilvigaster & ochraceiventer & paraguayensis & dinellii & aspersiventer & melanochrous \\
\hline O002_Tha_cae_ALG_020_BR_AL & 1 & 0 & 0 & 0 & 0 & 0 & 0 & 0 \\
\hline O006_Tha_cae_ALG_080_BR_AL & 1 & 0 & 0 & 0 & 0 & 0 & 0 & 0 \\
\hline O007_Tha_cae_ALG_085_BR_AL & 1 & 0 & 0 & 0 & 0 & 0 & 0 & 0 \\
\hline O008_Tha_cae_ALG_086_BR_AL & 1 & 0 & 0 & 0 & 0 & 0 & 0 & 0 \\
\hline O010_Tha_cae_ALG_102_BR_AL & 1 & 0 & 0 & 0 & 0 & 0 & 0 & 0 \\
\hline O032_Tha_cae_MZ_82637_BR_MG & 0 & 0.452 & 0.547 & 0 & 0 & 0 & 0 & 0 \\
\hline O078_Tha_cae_MZ_91196_BR_SC & 0 & 0.591 & 0.397 & 0.012 & 0 & 0 & 0 & 0 \\
\hline O079_Tha_cae_MZ_91197_BR_SC & 0 & 0.311 & 0.689 & 0 & 0 & 0 & 0 & 0 \\
\hline O097_Tha_cae_MZ_91661_BR_SP & 0 & 0.67 & 0.295 & 0.035 & 0 & 0 & 0 & 0 \\
\hline O134_Tha_cae_MZ_93176_BR_SP & 0 & 0.76 & 0.226 & 0.014 & 0 & 0 & 0 & 0 \\
\hline O214_Tha_cae_KU_3195_PA_ALT & 0 & 0 & 0 & 0 & 0.869 & 0.13 & 0 & 0 \\
\hline O216_Tha_cae_KU_3700_PA_ITA & 0 & 0.752 & 0.242 & 0.006 & 0 & 0 & 0 & 0 \\
\hline O217_Tha_cae_KU_3721_PA_CAA_ITA & 0 & 0.691 & 0.221 & 0.088 & 0 & 0 & 0 & 0 \\
\hline O230_Tha_cae_KU_21654_PE_PU & 0 & 0 & 0 & 0 & 0 & 0 & 0.708 & 0.292 \\
\hline O272_Tha_cae_ML_2030_BR_MG & 0 & 0.693 & 0.303 & 0.005 & 0 & 0 & 0 & 0 \\
\hline O273_Tha_cae_ML_2031_BR_G0 & 0 & 0.332 & 0.109 & 0.56 & 0 & 0 & 0 & 0 \\
\hline O288_Tha_cae_MCP_3306_BR_RS & 0 & 0.695 & 0.304 & 0.001 & 0 & 0 & 0 & 0 \\
\hline O299_Tha_cae_MCP_4843_BR_SC & 0 & 0.721 & 0.215 & 0.064 & 0 & 0 & 0 & 0 \\
\hline O349_Tha_cae_MPEG_T14940_BR_SC & 0 & 0.343 & 0.653 & 0.005 & 0 & 0 & 0 & 0 \\
\hline O390_Tha_cae_MPEG_T15691_BR_MG & 0 & 0.71 & 0.29 & 0 & 0 & 0 & 0 & 0 \\
\hline O450_Tha_cae_MPEG_CPEII037_BR_PE & 1 & 0 & 0 & 0 & 0 & 0 & 0 & 0 \\
\hline O453_Tha_cae_UWBM_77213_B0_TJ & 0 & 0 & 0 & 0 & 0.046 & 0.954 & 0 & 0 \\
\hline O603_Tha_cae_LSUMZ_105988_PE_PAS & 0 & 0 & 0 & 0 & 0 & 0 & 0.328 & 0.672 \\
\hline O604_Tha_cae_LSUMZ_171295_B0_SaC & 0 & 0 & 0 & 0 & 0.897 & 0.103 & 0 & 0 \\
\hline O605_Tha_cae_LSUMZ_168944_B0_SaC & 0 & 0 & 0 & 0 & 0.024 & 0.976 & 0 & 0 \\
\hline O606_Tha_cae_LSUMZ_170871_PE_L0 & 0 & 0 & 0 & 0 & 0 & 0 & 0 & 1 \\
\hline O607_Tha_cae_LSUMZ_179678_PE_PU & 0 & 0 & 0 & 0 & 0 & 0 & 0.964 & 0.036 \\
\hline O608_Tha_cae_MZUSP_81155_BR_SP & 0 & 0.51 & 0.471 & 0.018 & 0 & 0 & 0 & 0 \\
\hline
\end{tabular}


Table S4. Group membership in samples of UCEs of T. caerulescens (incomplete matrix).

\begin{tabular}{|c|c|c|c|c|c|c|c|c|}
\hline \multirow{2}{*}{$\begin{array}{c}\text { Clusters } \\
\text { Samples/Subspecies* }\end{array}$} & \multirow{2}{*}{$\begin{array}{c}\text { cearensis } \\
\text { cearensis }\end{array}$} & \multicolumn{3}{|c|}{ caerulescens } & \multicolumn{4}{|c|}{ Andean } \\
\hline & & caerulescens & gilvigaster & ochraceiventer & paraguayensis & dinellii & aspersiventer & melanochrous \\
\hline O002_Tha_cae_ALG_020_BR_AL & 1 & 0 & 0 & 0 & 0 & 0 & 0 & 0 \\
\hline O006_Tha_cae_ALG_080_BR_AL & 1 & 0 & 0 & 0 & 0 & 0 & 0 & 0 \\
\hline O007_Tha_cae_ALG_085_BR_AL & 1 & 0 & 0 & 0 & 0 & 0 & 0 & 0 \\
\hline O008_Tha_cae_ALG_086_BR_AL & 1 & 0 & 0 & 0 & 0 & 0 & 0 & 0 \\
\hline O010_Tha_cae_ALG_102_BR_AL & 1 & 0 & 0 & 0 & 0 & 0 & 0 & 0 \\
\hline O032_Tha_cae_MZ_82637_BR_MG & 0 & 0.934 & 0.065 & 0 & 0 & 0 & 0 & 0 \\
\hline O078_Tha_cae_MZ_91196_BR_SC & 0 & 0.732 & 0.239 & 0.028 & 0 & 0 & 0 & 0 \\
\hline O079_Tha_cae_MZ_91197_BR_SC & 0 & 0.038 & 0.962 & 0 & 0 & 0 & 0 & 0 \\
\hline O097_Tha_cae_MZ_91661_BR_SP & 0 & 0.742 & 0.257 & 0.001 & 0 & 0 & 0 & 0 \\
\hline O134_Tha_cae_MZ_93176_BR_SP & 0 & 0.98 & 0.017 & 0.002 & 0 & 0 & 0 & 0 \\
\hline O214_Tha_cae_KU_3195_PA_ALT & 0 & 0 & 0 & 0 & 0.923 & 0.077 & 0 & 0 \\
\hline O216_Tha_cae_KU_3700_PA_ITA & 0 & 0.288 & 0.709 & 0.003 & 0 & 0 & 0 & 0 \\
\hline O217_Tha_cae_KU_3721_PA_CAA_ITA & 0 & 0.429 & 0.57 & 0.001 & 0 & 0 & 0 & 0 \\
\hline O230_Tha_cae_KU_21654_PE_PU & 0 & 0 & 0 & 0 & 0 & 0 & 1 & 0 \\
\hline O272_Tha_cae_ML_2030_BR_MG & 0 & 0.345 & 0.011 & 0.644 & 0 & 0 & 0 & 0 \\
\hline O273_Tha_cae_ML_2031_BR_GO & 0 & 0.346 & 0.019 & 0.635 & 0 & 0 & 0 & 0 \\
\hline O288_Tha_cae_MCP_3306_BR_RS & 0 & 0.38 & 0.62 & 0 & 0 & 0 & 0 & 0 \\
\hline O299_Tha_cae_MCP_4843_BR_SC & 0 & 0.281 & 0.715 & 0.004 & 0 & 0 & 0 & 0 \\
\hline O349_Tha_cae_MPEG_T14940_BR_SC & 0 & 0.368 & 0.629 & 0.003 & 0 & 0 & 0 & 0 \\
\hline O390_Tha_cae_MPEG_T15691_BR_MG & 0 & 0.949 & 0.01 & 0.042 & 0 & 0 & 0 & 0 \\
\hline O450_Tha_cae_MPEG_CPEIII037_BR_PE & 1 & 0 & 0 & 0 & 0 & 0 & 0 & 0 \\
\hline O453_Tha_cae_UWBM_77213_B0_TJ & 0 & 0 & 0 & 0 & 0.238 & 0.762 & 0 & 0 \\
\hline O603_Tha_cae_LSUMZ_105988_PE_PAS & 0 & 0 & 0 & 0 & 0 & 0 & 0 & 1 \\
\hline O604_Tha_cae_LSUMZ_171295_B0_SaC & 0 & 0 & 0 & 0 & 0.932 & 0.068 & 0 & 0 \\
\hline O605_Tha_cae_LSUMZ_168944_B0_SaC & 0 & 0 & 0 & 0 & 0 & 1 & 0 & 0 \\
\hline O606_Tha_cae_LSUMZ_170871_PE_L0 & 0 & 0 & 0 & 0 & 0 & 0 & 0 & 1 \\
\hline O607_Tha_cae_LSUMZ_179678_PE_PU & 0 & 0 & 0 & 0 & 0 & 0 & 1 & 0 \\
\hline O608_Tha_cae_MZUSP_81155_BR_SP & 0 & 0.364 & 0.631 & 0.005 & 0 & 0 & 0 & 0 \\
\hline
\end{tabular}




\section{Chapter II}

Comparative phylogeography of passerine birds with a circumAmazonian distribution 


\section{Comparative phylogeography of passerine birds with a circum-Amazonian distribution}

\section{Abstract}

There are a number of common distributional patterns that have provided the foundations of our current knowledge of Neotropical biogeography. A distinctive pattern is the so-called "circumAmazonian distribution", which expands across the forested lowlands south and east of Amazonia, the Andean foothills, the Venezuelan Coastal Range, and the Tepuis. To date, there is no clear understanding of the processes giving rise to this distribution. To understand the evolutionary history of taxa exhibiting this pattern it is necessary to test biogeographic hypotheses offering mechanistic explanations. Comparative phylogeography allows more accurate phylogeographic hypotheses for these taxa, as well as better population genetic parameters. Comprehensive comparative studies aiming at unraveling the evolutionary and biogeographic mechanisms underlying the circum-Amazonian distribution have not been conducted yet, and only scarce descriptive information has been published. Therefore, the objective of this work was to elucidate the historical and biogeographic mechanisms underpinning circum-Amazonian distribution by performing comparative genomic analyses of a group of Suboscine passerines. Ultraconserved Elements (UCEs) were obtained for eight taxonomic groups to estimate population parameters and genealogical trees. For the Thamnophilidae species were inferred demographic histories with momi2. The best models of each taxon were analyzed in a comparative framework to relate them with previously proposed biogeographic hypotheses for the Neotropics and to propose plausible biogeographical scenarios for the circum-Amazonian pattern. The circum-Amazonian distributional pattern has two main phylogeographic units: an Andean (plus Central America 
region) and an eastern-forested region (Atlantic Forest ecoregion, forested areas around southeast of Amazonia), interconnected by a northern and southern corridor, allowing biotic interchanges between them (mainly from the southern) and hybridization. Species-tree analyses recovered (a) an Andean clade with two Andean subgroups in the northern Peru and central Andes, and (b) an eastern-forested clade including northern and central/southern Atlantic Forest subgroups. The demographic histories of the Thamnophilidae taxa suggest that diversification of the circumAmazonian taxa have a strong influence of climatic fluctuations during the Pleistocene, with interconnected refugia allowing phenotypic/genetic differentiation but maintaining a considerable level of gene flow during varying dry/cool and warm/humid periods. In addition, the results of this work opened interesting taxonomic questions about some taxa that could be covered in the future (T. ruficapillus/torquatus complex, Xiphocolaptes complex). 


\section{Introduction}

A major breakthrough in the understanding of earth's biodiversity is the different evolutionary, biogeographical, and environmental processes affecting the distribution of the species and the response to these processes (Darlington, 1959). In this sense, it is expected that species with similar geographical distributions would have also common history of processes/events molding their habitats (Humphries \& Parenti, 1999). Relatively new groups of analysis were developed in order to identify and understand the relationship between co-distributed species and the biogeographical/evolutionary processes affecting them, called as Comparative Phylogeography (CP) (Arbogast \& Kenagy, 2001; Hickerson et al., 2010). The main objective of CP is to search for concordant splits within contemporaneous, co-distributed species (Bermingham \& Avise, 1986). In this framework, the level of "phylogeographic congruence is a measure of the historical stability of the current species assemblage" (Zink, 2002), namely, a particular evolutionary reconstruction (a hypothesis) on co-distributed species affected by similar climatic/geological events would be more 'supported' while more individuals phylogeographic patterns being congruent. The CP has been applied in the study of multiple co-distributed taxa (Barker et al., 2015; Potter et al., 2017), mainly in areas of interest as the Neotropics (Françoso et al., 2016; Rincon-Sandoval et al., 2019; Sartorato Zanchetta et al., 2019).

As proved by several studies, the Neotropical biomes and ecosystems exhibit high biodiversity and a wide range of ecological/geological characteristics (Myers et al., 2000; Rull, 2011; Richardson \& Pennington, 2016; Dinerstein et al., 2017). In this way, extensive work has being developed to explain and understand this high diversity in the Neotropics, as the processes involved in that phenomenon, arising a varying number of hypotheses, based in both theoretical 
and empirical approaches (e.g. Sick, 1967; Haffer, 1969; Vuilleumier, 1971; Brown, 1979; Cracraft, 1985; Hooghiemstra \& van der Hammen, 1998; Garzón-Orduña et al., 2014). These hypotheses cover proposals from ecological perspectives like the Gradient Hypothesis (Endler, 1982) to those based on geographical isolation as Refuges (Haffer, 1969; Vanzolini \& Williams, 1970) and Rivers (see Wallace, 1854; Sick, 1967), and Paleogeographic ones as the Arch and the Lagoon Hypotheses (Patton \& Silva, 1997; Marroig \& Cerqueira, 1997). All these hypotheses have been subject to wide discussion, and several tests have been implemented to corroborate or refute their assumptions (Mayr \& O’Hara, 1986; Salo, 1987; Nores, 1999; Lougheed et al., 1999; Colinvaux et al., 2000; Haffer, 2008; FernAndes et al., 2012; Maldonado-Coelho et al., 2013; Garzón-Orduña et al., 2015; Rocha \& Kaefer, 2019, among others).

Despite the large variety of proposed evolutionary and biogeographic mechanisms intended to explain Neotropical diversity, our understanding remains scarce for some of these patterns. For instance, a considerable number of birds are distributed in the surroundings of the Amazonia but they are absent in the Amazonia itself (Remsen et al., 1991; Bates, 1997; Lovette, 2004), and there is no clear understanding of the mechanisms involved in that kind of distributions. Such distributional pattern is known as "circum-Amazonian distribution" (Figure 1) and is characterized by the presence of phylogenetically related groups mainly in "(a) montane forested areas on the humid slopes of the Andes and the Coastal Range of Venezuela or the Tepui region; and in (b) lowland forested areas south and east of the lowland forests of Amazonia" (Remsen et al., 1991). Remsen et al. (1991), in the first study describing the circum-Amazonian pattern, described that species as Platyrinchus mystaceus, Hemitriccus spp., Dysithamnus mentalis, Phyllomyias burmeisteri, and Elaenia albiceps, E. parvirostris, and E. obscura, among others, share this distributional pattern. Subsequent works have identified other taxa as circum- 
Amazonian. Bates (1997) stated that two species of Tiaris, T. obscura and T. fuliginosa, have a geographical distribution congruent with the proposed by Remsen et al. (1991). More examples of species exhibiting this circum-Amazonian pattern were presented by Lovette (2004) in the case of Phaeothlypis and by Batalha-Filho et al. (2013) in Synallaxis ruficapilla and S. moesta. Additionally, some species of Cercomacra (C. melanaria, C. ferdinandi, C. carbonaria, and the C. nigricans complex) and Tangara cayana fit partially into this distributional pattern (see Tello et al., 2014; Savit \& Bates, 2015). There are also examples in non-passerines such as the genus Pionus, in which the sordidus-maximiliani complex seem to exhibit complementary geographical ranges resulting in a circum-Amazonian distribution (see Ribas et al., 2007). Moreover, the circum-Amazonian distribution pattern was identified in other non-avian groups such as some insects (references related to insects) and plants (references related to plants) (e.g. Prado \& Gibbs, 1993; Erwin, 2000; Canals \& Johnson, 2000; Knapp, 2002; Irmler, 2009). Nevertheless, whereas the diversity and distribution patterns in adjacent Neotropical regions have been the focus of several studies, this complex pattern of distribution has not received enough attention, and the events and evolutionary processes behind it have not been thoroughly revealed.

Here, we implemented a comparative phylogeographic approach to infer common evolutionary histories from eight taxa of Passeriformes with circum-Amazonian distribution, using genomic information from Ultraconserved Elements (UCEs, Bejerano et al., 2004). The UCEs are highly conserved genomic sequences that allow the use of a large set of universal markers to infer relationships among lineages (Faircloth et al., 2012; Faircloth et al., 2015), and they can be used to estimate demographic and population parameters (Smith et al., 2013; Zarza et al., 2018; Myers et al., 2019; Oswald et al., 2019). We estimated the populational parameters and demographic history for each species, followed by the comparative analysis of their evolutionary histories. 
Lastly, we proposed plausible scenarios in order to explain the formation of this distributional pattern based mainly in the proposed hypotheses of diversification for the Neotropics. 


\section{Methods}

Analyzed taxa and sampling efforts

We used samples from eight taxonomic groups with a circum-Amazonian distributional pattern (see Table 1). These were: 1) Platyrinchus mystaceus (Tyrannidae); 2) the complex Xiphocolaptes albicollis, X. falcirostris, X. promeropirhynchus and X. major (Dendrocolaptidae) 3) Philydor rufum and 4) Lochmias nematura (Furnariidae); 5) the complexes Thamnophilus palliatus/T. tenuepunctatus; and 6) Thamnophilus ruficapillus/T. torquatus, 7) Dysithamnus mentalis and 8) Thamnophilus caerulescens (Thamnophilidae).

We gathered samples from ornithological collections in Brazil and the USA (see Table 2). In total, we included 602 vouchered tissue samples. Our sampling covered the majority of the species geographic ranges, but samples from the northernmost region of the Northern Andes (the montane-forested areas of the Colombian Andes and the Coastal Range of Venezuela and the Tepuis) were missing for some species (see Table S1).

DNA extraction

We extracted total genomic DNA from muscle tissues using the PureLink® Genomic DNA Mini kit (Invitrogen Inc.). We quantified genomic DNA concentrations using a Qubit 2.0 fluorometer (Life Technologies, Inc.). We sent at least 1,000 ng of genomic DNA for each sample (301 samples) to Rapid Genomics (Gainesville, FL). Libraries were enriched from 2,386 UCE loci that targeted a set of 2,560 probes (Faircloth et al., 2012, Tetrapods-UCE-2.5K version 1; Microarray, 
Ann Arbor, MI), following an open-source protocol (available at www.ultraconserved.org). Samples were multiplexed at 192 samples per lane on a 125 bp paired-end Illumina HiSeq 2500 run, yielding an average coverage of $18.66 \mathrm{X}$ per sample.

\section{Mitochondrial DNA}

As a preliminary assessment of population structure for each complex, we sequenced the mitochondrial gene NADH dehydrogenase 2 (ND2) for all individuals of each species and at least three individuals of their respective outgroups (see Table S2). We amplified and sequenced ND2 using standard PCR and Sanger sequencing protocols described elsewhere (Brumfield et al., 2007). We edited sequences and checked that they did not include stop codons or anomalous residues using Geneious v. 11.1.4 (www.geneious.com, Kearse et al. 2012). We aligned sequences with the MAFFT v.7 multiple alignment plugin (Katoh \& Standley, 2013) implemented in Geneious. We will be deposited the newly obtained sequences in GenBank (Accession numbers XXXXXXXXXXX).

We built a Median Joining Network - MJN - haplotype network (Bandelt et al., 1999) implemented in POPART (Leigh \& Bryant, 2015). Outgroup samples and short ingroup sequences ( $<700 \mathrm{bp}$ ) were excluded from the analysis and the matrix was trimmed to exclude any positions containing missing data (see Supplementary Material, Table S1). We selected the best substitution model for each species (see Table 3) using the corrected Akaike Information Criterion (AICc; Hurvich and Tsai 1989) implemented in jModeltest2 (Darriba et al., 2012) on the Cipres Science Gateway V 3.3 (Miller et al., 2010). We estimated a time-calibrated gene tree within a Bayesian framework implemented in the program BEAST2 v2.4.4 (Bouckaert et al. 2014). Based on the 
avian mtDNA substitution rate of 2.1\%/My (Weir \& Schluter, 2008), we used a lognormal relaxed molecular clock with a mean rate of 0.0105 for mtDNA. We used a Coalescent Constant Population prior with no restrictions on tree shape and a randomly generated tree as a starting tree. We ran analyses for a total of 50 million generations with a sampling frequency of 1,000 . We determined that replicate analyses converged (effective sample size values > 400) using Tracer 1.7.1 (Rambaut et al. 2018). Using TreeAnnotator v2.4.4 (Drummond et al. 2012, Bouckaert et al. 2014) and a burn-in of $30 \%$, we estimated a posterior distribution of topologies and the maximum clade credibility (MCC) tree.

\section{Edition and assembly of UCES}

We followed the Phyluce pipeline (Faircloth, 2016, https://github.com/faircloth-lab/phyluce) to process the raw sequences of the UCEs sequenced. Initially, Illumiprocessor 2.0.7 (Faircloth, 2013) and Trimmomatic 0.32 (Bolger et al., 2014) were implemented to trim adapters, barcodes and low quality regions. We used Trinity 2.0.6 (Grabherr et al., 2011) to perform the assembly (script phyluce_assembly_assemblo_trinity). To avoid including markers of different ploidy, we

identified, extracted, and removed Z-linked UCEs from the assemblies using Blast 2.7.7 (see Altschul et al., 1990; Camacho et al., 2009). Finally, we implemented the script phyluce_assembly_match_contigs_to_probes to match the assembled contigs to the UCE probes (uce-2.5k-probes.fasta). The results were exported in a $*$ fasta format. 
SNP calling

For each species, we extracted Single Nucleotide Polymorphisms (SNPs) from the UCE alignments using the methods described by Harvey et al. (2016), which are largely based on Phyluce (Faircloth, 2016). We extracted SNPs following two approaches using the script phyluce_assembly_match_counts. The first one yielded a 100\% complete matrix with no missing data for any individual in all loci, and the second one yielded an incomplete matrix including all data matching the target loci.

First, we created a $*$ fasta file with the loci extracted from the complete matrix of each species (phyluce_assembly_explode_get_fastas_file), and we chose a reference from the sequences analyzed; estimating the coverage and the mean length of recovered contigs (script phyluce_assembly_get_trinity_coverage, and phyluce_assembly_get_fasta_lengths). Secondly, we used bwa 0.7.7 (Li \& Durbin, 2009) to map raw reads from the samples for each species with their respective reference ( $\mathrm{Li}, 2013)$, Samtools 0.1.19 (Li et al., 2009) and Picard (http://broadinstitute.github.io/picard/) to create *bam files, mark duplicates from the PCRF and prepare the files to the next phase. We used the GATK 3.8.0 (McKenna et al., 2010) to extract the indels, SNPs, and do the phasing of sequences. The *vcf files created were exported in other formats to posterior demographic analyzes. Finally, we filter the loci in the complete and incomplete *vcf selecting one random SNP per locus from the biallelic SNPs recovered in each file (script randSnps.pl). In the end, we have two SNPs datasets (matrices), one complete and incomplete by each species. We implemented all the analysis in this work on the two matrices to compare the results in each of them. The complete matrices with few ( $<300$ loci by matrix) or zero loci extracted were excluded from de demographic analyses (see Table 4). 


\section{Population structure}

We inferred population structure from the SNPs matrices for each species using two multivariate approaches; a Principal Components Analysis - PCA - with the R packages adegenet/ape (Jombart, 2008 and Paradis et al., 2004), and a coefficients of mixture analyses with sNMF in the R package LEA (Frichot et al., 2014, Frichot \& François, 2015). The sNMF analyses were implemented with the following parameters; five $\alpha$ values $(10,50,100,500,1000), \mathrm{K}$ values of 1 to $10(\mathrm{~K}=1: 10)$, and 100 runs per $\mathrm{K}$ value, and the minimum cross-entropy as TRUE to estimate the best number of K. In the same way, we implemented a Discriminant Analysis of Principal Components - DAPC - (Jombart et al., 2010) within adegenet package recovering PCs with $80 \%$ of variance, and a maximum of 10 groups.

Species trees and gene trees

We ran three million iterations in SNAPP (Bryant et al., 2012) in two runs to identify the relationships among the clusters recovered in the PCA/sNMF analyzes using the SNPs extracted from the UCEs for each species. We evaluated the ESS values of the runs with Tracer 1.7.1 (Rambaut et al., 2018), merges the runs with logcombiner, and visualizes the topology with densitree to (programs from BEAST). 


\section{Demographic history}

For the species with an optimal sampling effort, we used the software momi2 to infer possible demographic scenarios for each species. momi2 used an SFS file that can be obtained from the SNPs extracted from the UCEs to infer demographic histories by fitting the observed value of the SFS to its expected value in a composite likelihood framework (Kamm et al., 2018).

We tested multiple models with different demographic scenarios for the populations of each species based on the results of PCA/DAPC/sNMF and SNAPP analyzes (see Figure 2), and the most informative were selected using the Akaike Information Criterion (AIC, Akaike, 1973). In general, we tested models that (a) are framed into the main hypothesis of diversification proposed (e.g. Refuge, Rivers hypotheses), models depicting (b) events of migration among the populations proposed for the taxa, (c) the effects glacial periods during the Pleistocene (Last Glacial Maximum, LGM), and (d) levels of population expansion. For each model (in each series of runs), we implemented 100 runs to avoid suboptimal results. With the run with the highest likelihood for each model, we evaluate the relative weight of the best model the Akaike Information Criterion (AIC, Akaike, 1973). In the same way, we run 100 bootstraps simulations to estimate confidence intervals of the parameters in the best model chosen in the AIC. Finally, based in the most informative models for each species, we looked for common scenarios across taxa that could explain a common history underlaying circum-Amazonian distributions. 


\section{Results}

mtDNA preliminary analyses and times of divergence

In general, we found evidence of considerable intraspecific genetic variation across taxa with signatures of recent population expansions (but see L. nematura and T. ruficapillus/torquatus complex). Haplotype networks are congruent with this signal in depicting geographical structure (see Figure S1 - S3) and Tables S3-S22 for a summary of these results).

Maximum likelihood and Bayesian gene tree estimation approaches (from this point, called ML and BI analyses, respectively, see Figures $3 a-3 c$ and S4 - S7) recovered all species as monophyletic, except for the T. palliatus/tenuepunctatus and T. ruficapillus/torquatus complexes, wherein current taxonomy is not in agreement with our results. In the first case, T. tenuepunctatus is embedded within the Andean clade of $T$. palliatus (northernmost individuals in the central Andes). In the second case, the T. ruficapillus from southern Atlantic Forest is more closely-related to the T. torquatus than it is to other T. ruficapillus Andean and Chacoan (see Figures 3a-S5).

In general, the ML and BI topologies across taxa give rise to some commonalities across taxa. First, there is a deep division between the Andean and Atlantic Forest populations $(L$. nematura, P. rufum, T. caerulescens and T. ruficapillus/torquatus complex) and persistent and well-supported clades restricted to the central and southern Atlantic Forest (D. mentalis, L. nematura, P. mystaceus, P. rufum and T. caerulescens). Furthermore, we were able to identify isolated and divergent populations restricted to the northern Atlantic Forest (P. mystaceus and $T$. caerulescens). 
Divergence times of Thamnophilid species (D. mentalis, T. caerulescens, $T$. palliatus/tenuepunctatus and T. ruficapillus/torquatus) from their outgroups varied from the Late Miocene to the Middle Pleistocene, with posterior divergences occurred since the early Pleistocene. For the Furnariid species (L. nematura and P. rufum) and P. mystaceus divergence starts in the Miocene/Pliocene, while the Xiphocolaptes complex have a most recent and rapid diversification, starting in the Calabrian (from X. ocellatus) and the Middle Pleistocene. A common pattern is a high rate of diversification from the early/middle Pleistocene in all taxa (see Figure $3 a-3 c)$.

UCE statistics and sequencing

UCEs sequencing, considering the samples from the 8 species complexes, resulted in an average of $4,139,618(\min =72,929, \max =13,782,612)$ read pairs per sample after trimming with Illumiprocessor; after assembling the reads we gathered an average of 12,441.86 UCEs contigs with a mean coverage (x) of 18.66 (see Tables $5-6$ ). In the end, we processed and analyzed 302 UCEs samples.

Population Structure in circum-Amazonian Passerines

Based on the geographical distributions and population structure of each species analyzed here, we identified three common demographical units (Figures $4-5$ ). Maybe the most persistent unit is the central-southern Atlantic Forest cluster(s), shared by populations of almost all species analyzed (D. mentalis, T. caerulescens, the T. ruficapillus/torquatus complex, P. mystaceus, L. 
nematura, . rufum, the species albicollis in the Xiphocolaptes complex). In these species, all analyzes recovered this cluster (PCA/DAPC, sNMF), with a considerable level of admixture in some species with populations of adjacent areas like the northern Atlantic Forest (e.g. $T$. ruficapillus/torquatus complex) and the central Andean regions (P. mystaceus, T. caerulescens). In addition, for D. mentalis and P. mystaceus, sNMF runs showed admixture between the centralsouthern Atlantic Forest and individuals of the Tepuis region (see Figures 5a and 5g).

A second main unit, recovered in T. caerulescens and P. mystaceus, was a northern Atlantic Forest cluster from the forested remnants of the Atlantic Forest ecoregion in the states of Alagoas and Pernambuco in Brazil ('Pernambuco Endemism Centre', see Figures 4b/5g - 4b/5g). In this area we observe signatures of admixture between the central-southern Atlantic Forest and central Andean populations in T. caerulescens, and with populations from the eastern Amazonian, Bolivia, and the Tepuis in P. mystaceus.

We also identified a complex of 'Andean' cluster across all taxa not as geographically delimited as in the previous two clusters. We identified a 'complete' Andean cluster that covers the northern/central Andes including the Tepuis and Central America regions (see maps of $D$. mentalis and P. mystaceus, and $P$. rufum in Figures $4 \mathrm{a} / 5 \mathrm{a}-4 \mathrm{f} / 5 \mathrm{f}-4 \mathrm{~g} / 5 \mathrm{~g}$ ). In the same way, populations from $T$. caerulescens and the T. ruficapillus/torquatus complex shared a central Andean cluster from northern Argentina/Bolivia to central Peru (Figures $4 b / 5 b-4 d / 5 d)$. Finally, a northern Peru cluster was recovered by Lochmias nematura T. palliatus/tenuepunctatus complex populations (Figures $4 \mathrm{c} / 5 \mathrm{c}-4 \mathrm{e} / 5 \mathrm{e}$ ).

sNMF analyses inferred a substantial level of admixture in the Andean clusters, mainly in individuals from two areas (Figures $5 \mathrm{a}-5 \mathrm{c}-5 \mathrm{~g}-5 \mathrm{~h}$ ). A first area from Bolivia to southern Peru as result of the contact between the southern Atlantic Forest and the Central Andean populations 
of species with a continuous distribution like D. mentalis, T. caerulescens, and P. mystaceus. A second contact zone is that between the northern and the central Andes (maybe influenced by the Huancabamba depression) that showed considerable admixture with forested areas of Brazil (D. mentalis) or with adjacent regions like central Andes, Central America and the Tepuis $(L$. nematura, P. mystaceus, Xiphocolaptes and T. palliatus/tenuepunctatus complexes. In some species, the number of optimal clusters inferred by sNMF was ambiguous due to very close values of cross-entropy estimates (see Tables S23-S30). In this case, we used the results from PCA/DAPC analyses and identified common results among all them (PCA/DAPC + sNMF). We summarized the results of the admixture analyses performed in sNMF the Figure $6 a-6 b$.

Species trees

In general, the topologies recovered by SNAPP showed high support for all scenarios/species analyzed (>60\%). We identified an Andean - forested Brazilian regions sister relationship, except for D. mentalis, T. caerulescens, and Xiphocolaptes complex (Figures 7a-7b). For D. mentalis, a northern Brazilian clade (subspecies emiliae) and its closest relative (subspecies affinis) are sisters to a comprehensive Andean clade (northern/central Andes + Tepuis + Central America). In turn, this clade is sister to the mentalis from the central-southern Atlantic Forest region (Figure 7a). In the Xiphocolaptes complex, the four scenarios tested (three to six clusters), showed mixed results, but it is clear that $X$. albicollis is monophyletic (see Figures $7 \mathrm{~b}$ and S9). For T. caerulescens, the central Andean and the southern Atlantic Forest clades formed a clade, related to a third group from the northern Atlantic Forest region (see Figure 7a). 
The phylogenetic relationships of clades from the eastern part of the circum-Amazonia distributional pattern (here 'the lowland forested areas south and east of the lowland forests of Amazonia' sensu Remsen et al., 1991) present some commonalities. A first pattern identified for the P. mystaceus and T. ruficapillus/torquatus complexes showed the sister relationship between the clades from the northeastern and the central/southern forested regions in Brazil. Also a second sister relationship between the Atlantic Forest populations of $L$. nematura and $T$. palliatus/tenuepunctatus with clades from forested areas of eastern Amazonia and Tepuis (a northern connection, see Figures S8 - S9).

Similarly, we identified common patterns in the western portion of the circum-Amazonian region. First, a central Andean group with two sub-clades, a north central and a south-central Andean clades, from northern to central Peru and from here to northern Argentina (south Bolivia), present in the L. nematura and T. palliatus/tenuepunctatus complex. Secondly, a most 'extended' clade, covering the Andes plus adjacent areas like the Tepuis and individuals from Central America in D. mentalis, P. mystaceus, Xiphocolaptes complex (Figures 7a-7b).

\section{Demographic modelling}

Due to the scarce sampling effort for some species analyzed (see Fig. S2a - S2h), we only conducted the demographic analyses of the antbird taxa (D. mentalis, T. caerulescens, the $T$. palliatus/tenuepunctatus and T. ruficapillus/torquatus complexes from Thamnophilidae), each with a three population scheme (based on the populational structure analyses).

We identified commons patterns among the best models inferred by momi 2 for each species (Figure 8). Detailed results for each species complex with AIC and parameters values can be found 
on table (see Tables 7 -10). In general, the models presented bidirectional migration among their populations, but with relatively low rates of migration (maximum values $25 \%-36 \%$ in $T$. palliatus/tenuepunctatus complex model). For $T$. palliatus/tenuepunctatus complex and D. mentalis, the rate of migration is higher from the populations of forested areas in Brazil to the Andean region that in the opposite direction. In T. caerulescens and the T. ruficapillus/torquatus complex, the higher migration rates seem to occur between the southern Atlantic Forest and Andean populations, congruent some results of the admixture analyses of sNMF, where populations from the connection between the regions have a 'high' levels of admixture (Figure 5). Mean divergence times also was inferred in these models, the populations of the four antbird species seems have a starting point of divergence in the Pleistocene, from early Gelasian $(T$. ruficapillus/torquatus complex) to Middle Pleistocene (T. caerulescens), similar to the found by BEAST in the ND2 analyses. Finally, the time of the events of migration among the populations also were estimated, and for three species (less T. caerulescens) these 'pulses' happened prior the Last Glacial Maximum (LGM) (Figure 8). 


\section{Discussion}

\section{Population structure of circum-Amazonian Passerines}

In this first phylogeograhic approach to the circum-Amazonian distributional pattern, we found considerable level of populational structure in the species cohabiting this distribution, wellsupported phylogroups and certain geographical congruence. In general, the identified clusters fit with biogeographical units proposed in diverse type of studies and taxonomic groups (Bates et al., 1998; Morrone, 2001; Silva et al., 2004; Dinerstein et al., 2017), and the phylogenetic relationships among the populations of almost all species showed a 'common' pattern.

First, we identified two main regions in the circum-Amazonian distributional pattern, the Andean and the Brazilian forested populations. This division can be 'strict' like P. rufum, L. nematura or T. ruficapillus/torquatus complex, with a clear separation between the two units with no admixture, or a relaxed like $T$. caerulescens, D. mentalis, and P. mystaceus, with intermediate clusters, contact zones and a considerable level of gene flow. Hybridization and clinal variation have been documented for these regions for T. caerulescens and D. mentalis (Todd, 1916; Brumfield, 2005; Isler et al., 2005; Zimmer \& Isler, 2019a), species with a continuous distribution along of a southern arch of the circum-Amazonian distribution (central Andes $\leftarrow \rightarrow$ southern Atlantic Forest/SDTFs connections). In turn, the presence of geographical variation/hybrid zones seems be influenced by latitudinal gradients, geological events, climatic variations during the Pleistocene, and secondary contact among isolated populations (Miller et al., 2010b; Herzog \& Kattan, 2011; Luebert \& Weigend, 2014; Chattopadhyay et al., 2017; Polato et al., 2018). 
Within the Brazilian forested regions, our analyses inferred other phylogeographic subunits, mainly related to the Atlantic Forest ecoregion. This forested areas have been continuously proposed as a region with high-levels of biodiversity, endemism, and a priority hotspot for conservation efforts (Myers et al., 2000). In addition, the populational analyses defined the northern portion of the Atlantic Forest as an independent cluster from the central-southern regions (see T. caerulescens, P. mystaceus). A refuge in this region during the Quaternary (Pernambuco refuge, see Carnaval \& Moritz, 2008; Carnaval et al., 2009), and the presence of the Rio São Francisco as barrier can have potential effect in the isolation of this region from the central/southern Atlantic Forest (but see Carnaval \& Moritz, 2008; Carvalho et al., 2017).

The demographic patterns in the Andean unit of the circum-Amazonia distribution is more complex, and the sampling effort did not allow us to make solid inferences about its populational structure and phylogenetic relationships (samples from Colombia, Venezuela, Ecuador and Tepuis were scarce). However, the clusters identified in this region present similarities to the identified by previous works. Morrone \& Uturbey (1997) identified a northern Peru area of endemism (our cluster from northern to central Peru) in a cladistics analysis about the historical biogeography of the northern Andes (see also Morrone, 1994). In addition, several authors considered this area as a 'transitional zone' between the northern and Central Andes (see Berry, 1982; Weigend, 2002). In this zone, the presence of the Huancabamba Depression is considered as a geographical barrier that prevents the passage of organisms through the mountainous chain. However, the isolation effect of this barrier does not seem relevant for certain groups as some amphibians and reptiles as the same species have a continuous distribution at both sides of the depression (Duellman, 1979). In the same way, similar analyses identified our central Andes cluster (central Peru to northern 
Argentina/Bolivia) as part of a biogeographical unit and possibly an important center of speciation (Cracraft, 1985; Morrone, 2014; Perez-Escobar et al., 2017).

Species trees and phylogenetics patterns

Similar to the populational structure results, the phylogenetic relationship of the circumAmazonian taxa analyzed here suggest certain level of geographical congruence. In the Brazilian forested populations were identified two clades, the northern and the central - southern Atlantic Forest groups, previously identified in phylogenetic reconstructions using toads and birds (Thomé et al., 2010; Batalha-Filho et al., 2013). However, we found that the species with a complete distribution in the Atlantic Forests regions (and adjacent forested areas) do not have a sister relationship between the two clades (see D'Horta et al., 2011; Franco et al., 2017 for examples with sister relationship between these two areas). In P. mystaceus, the central - southern clade is closest to the eastern-forested area of Amazonia (subspecies cancromus) that to the niveigularis clade (northern Atlantic Forest clade). In similar way, SNAPP inferred that in D. mentalis, the emiliae clade (northern Atlantic Forest + eastern Amazonia) as most related to the affinis clade (SDTFs south of Amazonia) that with the central - southern Atlantic Forest group. These results are congruent with studies of taxa with Atlantic Forest distribution (Carvalho et al., 2017; Lima et al., 2018; Machado et al., 2018).

The phylogenetic relationship within the Andean clusters seems defined in SNAPP, with the northern Peru and the central Andes clusters being monophyletic and related to the easternforested areas (but see ND2 results). In the same way, previous analyses showed that these two areas are part of a central Andean subunit (Berry, 1982; Morrone \& Uturbey, 1997). However, the 
relationships of the Andean unit with adjacent areas are not clear, maybe due to the missing samples in the northern Andes or the evolutionary complexity of the region. The reviewed literature identified the Tropical Andes as a complex geological/biogeographical unit, including areas the mountainous region of Venezuela but not the Tepuis (Gansser, 1973; Rivas-Martinez, 1983; Graham, 2009). Borges et al. (2018) concluded that the Pantepui region a biogeographic unit separated from the Andes, with probable past interconnections with the northern Andes (Bonaccorso \& Guayasamin, 2013). On the other hand, Dal Vechio et al. (2018) found a highly supported sister relationship between Atlantic Forest and Tepuis populations of Bothrops bilineatus, with a diversification from the Guiana shield to the northern Atlantic Forest via a forest corridor in the northeastern South America, also in concordance with the inferred by Lovette (2004) for Phaeothlypis populations. In relation to the Andes - Central American regions, the species covers this distribution showed two results, in D. mentalis the Andes + Central American samples forms a unique cluster, while P. mystaceus and the Xiphocolaptes complex presented a Central American and north Andean clusters.

Demographic modeling and the rise of the circum-Amazonian distribution

Summarizing the populational structure and modelling analyses, the formation of a circumAmazonian distributional pattern can be explained by two not exclusive types of expansion/diversification: a diversification via forested areas north to the Amazon forested lowlands (northern diversification, via Tepuis), and a southern diversification, via forested lowlands of east/southern Brazil joining to the Andes. 
Using as reference the models inferred for the thamnophilid species and their geographical distribution, a southern diversification seems more probable, with initial populations from forested regions from Brazil - e.g. Atlantic Forest ecoregion - expanding to southwest to central Andes (in T. caerulescens, D. mentalis, and the T. palliatus/tenuepunctatus complex), congruent with the proposed by Chapman (1926). Brumfield \& Edwards (2007) also suggested that the Andean populations (at least for $T$. caerulescens) represents a secondary invasion of the species via a 'forest bridge' between the southeastern Brazil and the central Andes. Multiple authors studied these possible connections between Andes and Atlantic Forest (Batalha-Filho et al., 2013; Trujillo-Arias et al., 2017; Cabanne et al., 2019). In a work about the biotic interchange between the Amazonian and the Atlantic Forest regions, Ledo \& Colli (2017) concluded that a southern route (southeastern forested $\leftarrow \rightarrow$ western Amazonian areas) were the most probable scenario to explain the connection between these regions, this same scenario can be framed into the central Andes $\leftarrow \rightarrow$ southern Atlantic Forest connection(s).

Among the hypotheses proposed to explain the diversification in the Neotropics summarized in the introduction, these models seems fit with the presence of refuges/forested spots interconnected during the climatic fluctuations in the Pliocene - Pleistocene (Refugia Hypothesis, Haffer, 1969, Vanzolini \& Williams, 1970), allowing partial isolations and intermittent gene flow among their populations, and proliferation of new lineages (see Figures $9-11$ ). From this proposal in 1969, several authors used the climatic fluctuations during the Cenozoic as explanation for diversification of lineages of multiple groups for the Amazonian (Richardson et al., 2001; Silva et al., 2018; Pupim et al., 2019), and non-Amazonian biotas (Madriñan et al., 2013; Thomaz et al., 2015; Pérez-Escobar et al., 2017; García-Vázquez et al., 2017). 
Another hypothesis, the Pleistocene Arch Hypothesis, can to explain the diversification of the species modelled (PAH, Prado \& Gibbs, 1993; 'PAT' in Mogni et al., 2015). In PAH, a continuum of relatively stable areas of non-Amazonian forests (Seasonally Dry Tropical Forests SDTFs) allows the migration and colonization of taxa during the Cenozoic. For instance, in the phylogeographic pattern of D. mentalis and the T. palliatus/tenuepunctatus complex, the SDTFs to south of the Amazonian forests could be serve as a corridor between the northeastern forested areas of Brazil and the central Andes during the Pleistocene (see Figure 9a-9b). SNAPP/sNMF supported this configuration, with continuous populations forming an 'arch' around of the Amazonian rainforest region. Despite the lack of widespread support of this hypothesis (see Mogni et al., 2015), some authors have supported PAH as a driver in the diversification in the Neotropics (Collevatti et al., 2012; Florentín et al., 2018), mainly using species of plants. On the other hand, the presence of refuges has more theoretical/empirical support in the reviewed literature (see Werneck et al., 2011; Arruda et al., 2018). For the species of Thamnophilidae analyzed here, the models fit better a refugia scenario, and for species like $D$. mentalis and the $T$. palliatus/tenuepunctatus complex, further methodological approaches are yet needed to elucidate this question.

Regarding divergence times, the four species of Thamnophilidae analyzed by momi2 showed events of diversification in the Pleistocene (but see T. ruficapillus/torquatus). These results were congruent with the BEATS analyses (mtDNA) and in general with the divergence times for others Thamnophilidae (e.g. Choueri et al., 2017; Ribas et al., 2018). In momi2, the estimation of divergence times seems very dependent of other parameters in the models (specially the populational size, $\mathrm{Ne}$ ), and it is necessary to be careful in the construction of the initial models. Additionally, due to the fact that UCEs do not have just one rate of substitution like the ND2 gene 
(a UCE contains hundreds of loci with hundreds of possible rates) a comparison of the times of divergence between mtDNA and UCEs analyses could be difficult. We tried to minimize these problems by testing multiple $\mathrm{Ne}$ values for the initial models, and used the substitution rate proposed by Nadachowska-Brzyska et al. (2015).

Some taxonomic and phylogenetic considerations of circum-Amazonian Passerines

The T. ruficapillus/torquatus complex was challenging to frame in the patterns explained so far. This taxonomic complex is a not monophyletic group, with the southern populations of $T$. ruficapillus being closest to T. torquatus (sNMF identified hybrid individuals between these two clusters) that with the Andean populations of the same taxon, result supported by mtDNA and UCEs information. In the reviewed literature, there are not studies specifically about this complex. In their work about the genus Thamnophilus, Brumfield \& Edwards (2007) found that in the group called the 'barred clade', the ruficapillus/torquatus complex was indeed a monophyletic group, with a common ancestor that could be a highland-restricted or a lowlands-to-highlands taxon. A possible scenario is that of "lowlands-to-highlands" origin from the southern Atlantic Forest region moving west to the central Andes (Andean ruficapillus populations) and north to the forested areas in central/northern Brazil, with posterior isolation of the morphologically differentiated $T$. torquatus. A recent secondary contact could explain the hybrid zone between the southern $T$. ruficapillus and the T. torquatus populations. A deeper analysis of this complex that include taxonomy, ecology and evolutionary will be important to elucidate what is going on in these species. 
In the Thamnophilus palliatus/tenuepunctatus complex, the populational analyses presented not recognizable differences between the two species (but see the ND2 topologies). The only two samples of T. tenuepunctatus (extreme northern Peru and southern Ecuador) fall into the northern Peru cluster of $T$. palliatus, but with high levels of admixture (sNMF analysis). In the same way, the sample collected in eastern Colombia (department of Vichada), a locality outside of the species distributions, seems to be part of the Amazonian cluster, possibly representing an undescribed taxon. Based on the handbook of the Birds of the World (HBW, Zimmer \& Isler, 2019b), the species have adjoining ranges with no apparent barriers and no intergradation. However, our results imply a possible contact zone and hybridization at a genetic level. A better sampling effort help to clarify this complex.

In the Xiphocolaptes complex, all structural analyses support the existence of a X. albicollis cluster/clade (from Atlantic Forest ecoregion), being the only taxon recovered as an independent unit within the complex. In the same way, X. falcirostris seems be an independent cluster, but fails in the DAPC analyses and one scenario of sNMF, doing part of a cluster including the promeropirhynchus samples from the Tepuis and lowland samples of Central America.

The phylogenetic relationships in Xiphocolaptes are obscure. Nevertheless, we recovered $X$. albicollis as a well-supported clade consistent in all scenarios tested by SNAPP (see Figures 7b S7). In addition, we recovered a well-supported clade formed by the Andean cluster of $X$. promeropirhynchus (promeropirhynchus group of Marantz et al. 2019) and X. major, in concordance with the found by Raikow (1994) and Derryberry et al. (2011). X. falcirostris was also recovered by the analysis. Finally, T. promeropirhynchus is not monophyletic, but, like proposed by Marantz et al. (2019), this species can be divided in three groups, an Andean clade (including montane individuals of Central America + X. major), a Amazonian, and a lowlands of 
central America (plus Tepuis) clade. Like the two anterior complexes, other type of information will be useful to resolve the taxonomy/systematics of this group of species.

\section{Conclusions}

In this first phylogeographic comparative approach to the understanding of the circum-Amazonian distributional pattern using genomic data of Passerines, we found general congruence among the populational structure, phylogenetic relationships, and demographic histories of the taxa analyzed. We defined two main units: the Andean and the Brazilian forested phylogeographic region(s), disjointed complete or partially via a northern (northern Andes $\leftarrow \rightarrow$ Tepuis $\leftarrow \rightarrow$ Atlantic Forest) or southern interconnection (southern Atlantic Forest $\leftarrow \rightarrow$ central Andes). Contact zones among clusters included individuals with considerable levels of admixture, supports the possibility of events of hybridization among populations, mainly in the northern - southern interconnections. Species trees analyses inferred well-supported clades from central/southern and northern Atlantic Forest populations. In the same way, we identified central Andean clades (northern Peru and central Peru - Bolivia), but a bigger sampling effort will be necessary in the north Andean region. Demographic histories of the Thamnophilidae taxa seems to be product of a recent diversification with climatic fluctuations throughout the Quaternary as its main influence, fitting into a Refugia context previously proposed by other authors. However, at least to D. mentalis and the Thamnophilus palliatus/tenuepunctatus complex, alternative hypotheses (like corridors of STDFs vegetation during the Pleistocene) could not be discarded. In addition, our results raise new question about the taxonomy and systematics of the circum-Amazonian species (the $T$. ruficapillus/torquatus, T. palliatus/tenuepunctatus, and the Xiphocolaptes complexes). Future 
studies about the circum-Amazonian distribution have to cover other taxonomic groups outside Aves, phenotypic and ecological data, and the implementation of comparative methodologies that can include all those parameters for estimation of demographic/evolutionary scenarios that explain in deep the past and current dynamics of the circum-Amazonian distributional pattern. 


\section{References}

Akaike, H. (1973). Information theory and an extension of the maximum likelihood principle. International Symposium Information on theory Information and an extension Theory, (pp. 267281).

Altschul, S. F., Gish, W., Miller, W., Myers, E. W., \& Lipman, D. J. (1990). Basic local alignment search tool. Journal of Molecular Biology, 215(3), 403 - 410.

Arbogast, B. S. \& Kenagy, G. J. (2001). Comparative phylogeography as an integrative approach to historical biogeography. Journal of Biogeography, 28, 819-825.

Arruda, D. M., Schaefer, C. E. G. R., Fonseca, R. S., Solar, R. R. C., \& FernAndes-Filho, E. I. (2018). Vegetation cover of Brazil in the last $21 \mathrm{ka}$ : New insights into the Amazonian refugia and Pleistocenic Arc Hypotheses. Global Ecology and Biogeography, 27, 47-56.

Bandelt, H.-J., Forster, P., \& Röhl, A. (1999). Median-joining networks for inferring intraspecific phylogenies. Molecular Biology and Evolution, 16(1), 37-48.

Barker, B. S., Rodríguez-Robles, J. A., \& Cook, J. A. (2015). Climate as a driver of tropical insular diversity: comparative phylogeography of two ecologically distinctive frogs in Puerto Rico. Ecography, 38(8), 769-781.

Batalha-Filho, H., Irestedt, M., Fjeldså, J., Ericson, P. G. P., Silveira, L. F., \& Miyaki, C. Y. (2013). Molecular systematics and evolution of the Synallaxis ruficapilla complex (Aves: Furnariidae) in the Atlantic Forest. Molecular Phylogenetics and Evolution, 67, 86-94.

Bates, J. M. (1997). Distribution and geographic variation in three South American grassquits (Emberizinae, Tiaris). Ornithological Monographs, 48, 91-110. 
Bates, J. M., Hackett, S. J., \& Cracraft, J. (1998). Area-relationships in the Neotropical lowlands: an hypothesis based on raw distributions of passerine birds. Journal of Biogeography, 25, 783793.

Bejerano, G., Pheasant, M., Makunin, I., Stephen, S., Kent, W. J., Mattick, J. S., \& Haussler, D. (2004). Ultraconserved elements in the human genome. Science, 304, 1321-1325.

Bermingham, E. \& Avise, J. C. (1986). Molecular zoogeography of freshwater fishes in the southeastern United States. Genetics, 113, 939-965.

Berry, P. E. (1982). The systematics and evolution of Fuchsia sect. fuchsia (Onagraceae). Annals of the Missouri Botanical Garden, 69, 1-198.

Bolger, A. M., Lohse, M., \& Usadel, B. (2014). Trimmomatic: A flexible trimmer for illumina sequence data. bioinformatics. Bioinfor, 30(15), 2114-2120.

Bonaccorso, E. \& Guayasamin, J. M. (2013). On the origin of pantepui montane biotas: A perspective based on the phylogeny of Aulacorhynchus toucanets. PLoS ONE, 8(6), e67321.

Borges, S. H., Santos, M. P. D., Moreira, M., Baccaro, F., Capurucho, J. M. G., \& Ribas, C. (2018). Dissecting bird diversity in the pantepui area of endemism, northern South America. Journal of Ornithology, 159(4), 1073-1086.

Bouckaert, R., Heled, J., Kühnert, D., Vaughan, T., Wu, C.-H., Xie, D., Suchard, M. A., Rambaut, A., \& Drummond, A. J. (2014). Beast 2: A software platform for bayesian evolutionary analysis. PLOS Computational Biology, 10(4), 1-6.

Brown, K. S. (1979). Ecologia Geográfica e Evolução nas Florestas Neotropicais. Universidade Estadual de Campinas. 
Brumfield, R. T. (2005). Mitochondrial variation in Bolivian populations of the variable Antshrike (THAMNOPHILUS CAERULESCENS). The Auk, 122(2), 414-432.

Brumfield, R. T. \& Edwards, S. V. (2007). Evolution into and out of the Andes: A bayesian analysis of historical diversification in Thamnophilus antshrikes. Evolution, 61, 346-367.

Brumfield, R. T., Tello, J. G., Cheviron, Z., Carling, M. D., Crochet, N., \& Rosenberg, K. V. (2007). Phylogenetic conservatism and antiquity of a tropical specialization: Army-ant-following in the typical antbirds (Thamnophilidae). Molecular Phylogenetics and Evolution, 45, 1-13.

Bryant, D., Bouckaert, R., Felsenstein, J., Rosenberg, N. A., \& RoyChoudhury, A. (2012). Inferring species trees directly from biallelic genetic markers: Bypassing gene trees in a full coalescent analysis. Molecular Biology and Evolution, 29(8), 1917-1932.

Cabanne, G. S., Campagna, L., Trujillo-Arias, N., Naoki, K., Gómez, I., Miyaki, C. Y., Santos, F. R., Dantas, G. P. M., Aleixo, A., Claramunt, S., Rocha, A., Caparroz, R., Lovette, I. J., \& Tubaro, P. L. (2019). Phylogeographic variation within the buff-browed foliage-gleaner (Aves: Furnariidae: Syndactyla rufosuperciliata) supports an Andean-Atlantic forests connection via the Cerrado. Molecular Phylogenetics and Evolution.

Camacho, C., Coulouris, G., Avagyan, V., Ma, N., Papadopoulos, J., Bealer, K., \& Madden, T. L. (2009). Blast+: architecture and applications. BMC Bioinformatics, 10(1), 421.

Canals, G. \& Johnson, K. (2000). A new species of Angulopis (Lycaenidae, Eumaeini) from relict coastal forest in east-central Argentina. The taxonomic report of the International Lepidoptera Survey, 2(3), 1-5.

Carnaval, A. C., Hickerson, M. J., Haddad, C. F. B., Rodrigues, M. T., \& Moritz, C. (2009). Stability predicts genetic diversity in the Brazilian Atlantic Forest hotspot. Science, 323(5915), 785-789. 
Carnaval, A. C. \& Moritz, C. (2008). Historical climate modelling predicts patterns of current biodiversity in the Brazilian Atlantic Forest. Journal of Biogeography, 35(7), 1187-1201.

Carvalho, C. D. S., Nascimento, N. F. F. D., \& Araujo, H. F. P. D. (2017). Bird distributional patterns support biogeographical histories and are associated with bioclimatic units in the Atlantic Forest, Brazil. Zootaxa, 4337(2), 223-242.

Chapman, F. M. (1926). The distribution of bird-life in Ecuador. Bull. Am. Mus. Nat. Hist., 55, $1-$ 784. chapman.1926_p87.

Chattopadhyay, B., Garg, K. M., Gwee, C. Y., Edwards, S. V., \& Rheindt, F. E. (2017). Gene flow during glacial habitat shifts facilitates character displacement in a Neotropical flycatcher radiation. BMC Evolutionary Biology, 17(1), 210.

Choueri, É. L., Gubili, C., Borges, S. H., Thom, G., Sawakuchi, A. O., Soares, E. A. A., \& Ribas, C. C. (2017). Phylogeography and population dynamics of antbirds (Thamnophilidae) from Amazonian fluvial islands. Journal of Biogeography, (pp. n/a-n/a).

Colinvaux, P. A., Oliveira, P. E. D., \& Bush, M. B. (2000). Amazonian and Neotropical plant communities on glacial time-scales: The failure of the aridity and refuge hypotheses. Quaternary Science Reviews, 19, 141-169.

Collevatti, R. G., Terribile, L. C., Lima-Ribeiro, M. S., Nabout, J. C., de Oliveira, G., Rangel, T. F., Rabelo, S. G., \& Diniz-Filho, J. A. F. (2012). A coupled phylogeographical and species distribution modelling approach recovers the demographical history of a Neotropical seasonally dry forest tree species. Molecular Ecology, 21(23), 5845-5863.

Cracraft, J. (1985). Historical biogeography and patterns of differentiation within the South American avifauna: areas of endemism. Ornithological Monographs, 36, 49-84. 
D’horta, F. M., Cabanne, G. S., Meyer, D., \& Miyaki, C. Y. (2011). The genetic effects of late Quaternary climatic changes over a tropical latitudinal gradient: diversification of an Atlantic forest passerine. Molecular Ecology, 20(9), 1923-1935.

Dal Vechio, F., Prates, I., Grazziotin, F. G., Zaher, H., \& Rodrigues, M. T. (2018). Phylogeography and historical demography of the arboreal pit viper Bothrops bilineatus (Serpentes, Crotalinae) reveal multiple connections between Amazonian and Atlantic rain forests. Journal of Biogeography, 45(10), 2415-2426.

Darlington, Jr., P. J. (1959). Area, climate, and evolution. Evolution, 13(4), 488-510.

Darriba, D., Taboada, G. L., Doallo, R., \& Posada, D. (2012). jmodeltest 2: more models, new heuristics and parallel computing. Nature Methods, 9(8), 772.

Derryberry, E. P., Claramunt, S., Derryberry, G., Chesser, R. T., Cracraft, J., Aleixo, A., PérezEmán, J., Remsen, J. V., \& Brumfield, R. T. (2011). Lineage diversification and morphological evolution in a large-scale continental radiation: The Neotropical ovenbirds and woodcreepers (Aves: Furnariidae). Evolution, 65(10), 2973-2986.

Dinerstein, E., Olson, D., Joshi, A., Vynne, C., Burgess, N. D., Wikramanayake, E., Hahn, N., Palminteri, S., Hedao, P., Noss, R., Hansen, M., Locke, H., Ellis, E. C., Jones, B., Barber, C. V., Hayes, R., Kormos, C., Martin, V., Crist, E., Sechrest, W., Price, L., Baillie, J. E. M., Weeden, D., Suckling, K., Davis, C., Sizer, N., Moore, R., Thau, D., Birch, T., Potapov, P., Turubanova, S., Tyukavina, A., de Souza, N., Pintea, L., Brito, J. C., Llewellyn, O. A., Miller, A. G., Patzelt, A., Ghazanfar, S. A., Timberlake, J., Klöser, H., Shennan-Farpón, Y., Kindt, R., Lilles ̃̂f Â,, J.-P. B., van Breugel, P., Graudal, L., Voge, M., Al-Shammari, K. F., \& Saleem, M. (2017). An ecoregionbased approach to protecting half the terrestrial realm. BioScience, (pp. 1-12). 
Drummond, A. J., Suchard, M. A., Xie, D., \& Rambaut, A. (2012). Bayesian phylogenetics with beauti and the Beast 1.7. Molecular Biology and Evolution, 29(8), 1969-1973.

Duellman, W. E. (1979). The herpetofauna of the Andes: Patterns of distribution, origin, differentiation, and present communities. In The South American Herpetofauna: It's Origin, Evolution and Dispersal, chapter 15, (pp. 371-460). Number 7. The Museum of Natural History, University of Kansas.

Endler, J. (1982). Pleistocene forest refuges: fact or fancy? In Biological Diversification in the Tropics, chapter 35, (pp. 641-657). New York: Columbia University Press.

Erwin, T. L. (2000). Arboreal beetles of Neotropical forests: Taxonomic supplement for the Agra virgata and ohausi groups with a new species and additional distribution records (Coleoptera: Carabidae). The Coleopterists Bulletin, 54(2), 251-262.

Faircloth, B. C. (2013). illumiprocessor: a trimmomatic wrapper for parallel adapter and quality trimming.

Faircloth, B. C. (2016). Phyluce is a software package for the analysis of conserved genomic loci. Bioinformatics, 32(5), 786-788.

Faircloth, B. C., Branstetter, M. G., White, N. D., \& Brady, S. G. (2015). Target enrichment of ultraconserved elements from arthropods provides a genomic perspective on relationships among hymenoptera. Molecular Ecology Resources, 15, 489-501.

Faircloth, B. C., Mccormack, J. E., Crawford, N. G., Harvey, M. G., Brumfield, R. T., \& Glenn, T. C. (2012). Ultraconserved elements anchor thousands of genetic markers spanning multiple evolutionary timescales. Systematic Biology, 61(5), 717-726. 
FernAndes, A. M., Wink, M., \& Aleixo, A. (2012). Phylogeography of the chestnut-tailed antbird (Myrmeciza hemimelaena) clarifies the role of rivers in Amazonian biogeography. Journal of Biogeography, 39, 1524-1535.

Florentín, J. E., Arana, M. D., Prado, D. E., Morrone, J. J., \& Salas, R. M. (2018). Diversification of Galianthe species (rubiaceae) in the Neotropical seasonally dry forests: a case study of a mainly subshrubby genus. Plant Ecology and Evolution, 151(2), 161-174.

Franco, F. F., Jojima, C. L., Perez, M. F., Zappi, D. C., Taylor, N., \& Moraes, E. M. (2017). The xeric side of the Brazilian Atlantic forest: The forces shaping phylogeographic structure of cacti. Ecology and Evolution, (pp. n/a-n/a).

Françoso, E., Zuntini, A. R., Carnaval, A. C., \& Arias, M. C. (2016). Comparative phylogeography in the Atlantic forest and Brazilian savannas: pleistocene fluctuations and dispersal shape spatial patterns in two bumblebees. BMC Evolutionary Biology, 16, 267.

Frichot, E. \& François, O. (2015). LEA: An R package for landscape and ecological association studies. Methods in Ecology and Evolution, 6, 925-929.

Frichot, E., Mathieu, F., Trouillon, T., Bouchard, G., \& François, O. (2014). Fast and efficient estimation of individual ancestry coefficients. Genetics, 196, 973-983.

Gansser, A. (1973). Facts and theories on the Andes: Twenty-sixth William Smith lecture. Journal of the Geological Society, 129, 93-131.

García-Vázquez, D., Bilton, D. T., Foster, G. N., \& Ribera, I. (2017). Pleistocene range shifts, refugia and the origin of widespread species in western Palaearctic water beetles. Molecular Phylogenetics and Evolution, 114, 122-136. 
Garzón-Orduña, I. J., Benetti-Longhini, J. E., \& Brower, A. V. Z. (2014). Timing the diversification of the Amazonian biota: butterfly divergences are consistent with Pleistocene refugia. Journal of Biogeography, 41, 1631-1638.

Garzón-Orduña, I. J., Benetti-Longhini, J. E., \& Brower, A. V. Z. (2015). Competing paradigms of Amazonian diversification and the Pleistocene refugium hypothesis. Journal of Biogeography, 42, 1349-1363.

Grabherr, M. G., Haas, B. J., Yassour, M., Levin, J. Z., Thompson, D. A., Amit, I., Adiconis, X., Fan, L., Raychowdhury, R., Zeng, Q., Chen, Z., Mauceli, E., Hacohen, N., Gnirke, A., Rhind, N., di Palma, F., Birren, B. W., Nusbaum, C., Lindblad-Toh, K., Friedman, N., \& Regev, A. (2011). Full-length transcriptome assembly from RNA-Seq data without a reference genome. Nature Biotechnology, 29(7), 644-652.

Graham, A. (2009). The Andes: a geological overview from a biological perspective. Annals of the Missouri Botanical Garden, 96(3), 371-385.

Haffer, J. (1969). Speciation in Amazonian forest birds. Science, New Series, 165, 131-137.

Haffer, J. (2008). Hypotheses to explain the origin of species in Amazonia. Brazilian Journal of Biology, 68(4), 917-947.

Harvey, M. G., Smith, B. T., Glenn, T. C., Faircloth, B. C., \& Brumfield, R. T. (2016). Sequence capture versus restriction site associated DNA sequencing for shallow systematics. Systematic Biology, 65(5), 910-924.

Herzog, S. K. \& Kattan, G. H. (2011). Patterns of Diversity and Endemism in the Birds of the Tropical Andes. In Climate Change and Biodiversity in the Tropical Andes, chapter 18, (pp. 245- 
259). Inter-American Institute for Global Change Research (IAI) and Scientific Committee on Problems of the Environment (SCOPE), Paris.

Hickerson, M. J., Carstens, B., Cavender-Bares, J., Crandall, K., Graham, C., Johnson, J., Rissler, L., Victoriano, P., \& Yoder, A. (2010). Phylogeography's past, present, and future: 10 years after Avise, 2000. Molecular Phylogenetics and Evolution, 54, 291-301.

Hooghiemstra, H. \& van der Hammen, T. (1998). Neogene and Quaternary development of the Neotropical rain forest: the forest refugia hypothesis, and a literature overview. Earth-Science Reviews, 44, 147-183.

Humphries, C. \& Parenti, L. (1999). Cladistic Biogeography. Oxford University Press, 2nd ed edition.

Hurvich, C. M. \& Tsai, C.-L. (1989). Regression and time series model selection in small samples. Biometrika, 76(2), 297-307.

Irmler, U. (2009). New species and records of the genus Lispinus with a key to the species from peru (Coleoptera: Staphylinidae: Osoriinae). Zootaxa, 2263, 42-58.

Isler, M. L., Isler, P. R., Brumfield, R. T., \& Zink, R. M. (2005). Clinal variation in vocalizations of an antbird (Thamnophilidae) and implications for defining species limits. The Auk, 122(2), 433444.

Jombart, T. (2008). adegenet: a R package for the multivariate analysis of genetic markers. Bioinformatics, 24(11), 1403-1405.

Jombart, T., Devillard, S., \& Balloux, F. (2010). Discriminant analysis of principal components: a new method for the analysis of genetically structured populations. BMC Genetics, 11(1), 94. 
Kamm, J. A., Terhorst, J., Durbin, R., \& Song, Y. S. (2018). Efficiently inferring the demographic history of many populations with allele count data. bioRxiv.

Katoh, K. \& Standley, D. M. (2013). MAFFT Multiple Sequence Alignment Software Version 7: Improvements in Performance and Usability. Molecular Biology and Evolution, 30(4), 772-780.

Kearse, M., Moir, R., Wilson, A., Stones-Havas, S., Cheung, M., Sturrock, S., Buxton, S., Cooper, A., Markowitz, S., Duran, C., Thierer, T., Ashton, B., Meintjes, P., \& Drummond, A. (2012). Geneious basic: An integrated and extendable desktop software platform for the organization and analysis of sequence data. BIOINFORMATICS, 28(12), 1647-1649.

Knapp, S. (2002). Assessing patterns of plant endemism in Neotropical uplands. The Botanical Review, 68(1), 22-37.

Ledo, R. M. D. \& Colli, G. R. (2017). The historical connections between the Amazon and the Atlantic forest revisited. Journal of Biogeography, 44(11), 2551-2563.

Leigh, J. W. \& Bryant, D. (2015). popart: full-feature software for haplotype network construction. Methods in Ecology and Evolution, 6(9), 1110-1116.

Li, H. (2013). Aligning sequence reads, clone sequences and assembly contigs with bwa-mem. $\operatorname{arXiv.}$

Li, H. \& Durbin, R. (2009). Fast and accurate short read alignment with burrows-wheeler transform. Bioinformatics, 25(14), 1754-1760.

Li, H., Handsaker, B., Wysoker, A., Fennell, T., Ruan, J., Homer, N., Marth, G., Abecasis, G., Durbin, R., \& Subgroup. G. P. D. P. (2009). The sequence alignment/map format and samtools. Bioinformatics, 25(16), 2078-2079.

Lima, M. G., de Sousa e Silva-Júnior, J., Cerný, D., Buckner, J. C., Aleixo, A., Chang, J., Zheng, J., Alfaro, M. E., Martins, A., Fiore, A. D., Boubli, J. P., \& Alfaro, J. W. L. (2018). A 
phylogenomic perspective on the robust capuchin monkey (Sapajus) radiation: First evidence for extensive population admixture across South America. Molecular Phylogenetics and Evolution, $124,137-150$.

Lougheed, S. C., Gascon, C., Jones, D. A., Bogart, J. P., \& Boag, P. T. (1999). Ridges and rivers: a test of competing hypotheses of Amazonian diversification using a dart-poison frog (Epipedobates femoralis). Proceedings of the Royal Society of London B: Biological Sciences, 266(1431), 1829-1835.

Lovette, I. J. (2004). Molecular phylogeny and plumage signal evolution in a Trans Andean and circum Amazonian avian species complex. Molecular Phylogenetics and Evolution, 32, 512-523.

Luebert, F. \& Weigend, M. (2014). Phylogenetic insights into Andean plant diversification. Frontiers in Genetics, 2, 27.

Machado, L. F., Loss, A. C., Paz, A., Vieira, E. M., Rodrigues, F. P., \& Marinho-Filho, J. (2018). Phylogeny and biogeography of Phyllomys (Rodentia: Echimyidae) reveal a new species from the cerrado and suggest miocene connections of the amazon and Atlantic forest. Journal of Mammalogy, 99(2), 377-396.

Madriñán, S., Cortés, A. J., \& Richardson, J. E. (2013). Páramo is the world's fastest evolving and coolest biodiversity hotspot. Frontiers in Genetics, 4, 192.

Maldonado-Coelho, M., Blake, J. G., Silveira, L. F., Batalha-filho, H., \& Ricklefs, R. E. (2013). Rivers, refuges and population divergence of fire-eye antbirds (Pyriglena) in the amazon basin. Journal of Evolutionary Biology, 26, 1090-1107.

Marantz, C.A., Aleixo, A., Bevier, L.R. \& Patten, M.A. (2019). Strong-billed Woodcreeper (Xiphocolaptes promeropirhynchus). In: del Hoyo, J., Elliott, A., Sargatal, J., Christie, D.A. \& de 
Juana, E. (eds.). Handbook of the Birds of the World Alive. Lynx Edicions, Barcelona. (retrieved from https://www.hbw.com/node/56609 on 24 July 2019).

Marroig, G. \& Cerqueira, R. (1997). Plio-pleistocene South American history and the amazon Lagoon Hypothesis: a piece in the puzzle of Amazonian diversification. Journal of Comparative Biology, 2(2), 103-119.

Mayr, E. \& O’Hara, R. J. (1986). The biogeographic evidence supporting the Pleistocene forest refuge hypothesis. Evolution, 40(1), 55-67.

McKenna, A., Hanna, M., Banks, E., Sivachenko, A., Cibulskis, K., Kernytsky, A., Garimella, K., Altshuler, D., Gabriel, S., Daly, M., \& DePristo, M. A. (2010). The genome analysis toolkit: A MapReduce framework for analyzing next-generation DNA sequencing data. Genome Research, 20(9), 1297-1303.

Miller, M. A., Pfeiffer, W., \& Schwartz, T. (2010). Creating the CIPRES science gateway for inference of large phylogenetic trees. In Proceedings of the Gateway Computing Environments Workshop (GCE) (pp. 1-8). New Orleans, LA.

Miller, M. J., Bermingham, E., Klicka, J., Escalante, P., \& Winker, K. (2010). Neotropical birds show a humped distribution of within-population genetic diversity along a latitudinal transect. Ecology Letters, 13(5), 576-586.

Mogni, V. Y., Oakley, L. J., \& Prado, D. E. (2015). The distribution of woody legumes in Neotropical Dry Forests: the Pleistocene Arc Theory 20 years on*. Edinburgh Journal of Botany, 72(1), 35-60.

Morrone, J. J. (1994). On the identification of areas of endemism. Systematic Biology, 43, 438441. 
Morrone, J. J. \& Urtubey, E. (1997). Historical biogeography of the northern Andes: A cladistics analysis based of five genera of Rhytirrhinini (Coleoptera: Curculionidae) and barnadesia (asteraceae). Biogeographica, 73, 115-121.

Morrone, J. J. (2001). Biogeografía de América Latina y el Caribe. GORFI, S.A.

Myers, N., Mittermeier, R. A., Mittermeier, C. G., da Fonseca, G. A. B., \& Kent, J. (2000). Biodiversity hotspots for conservation priorities. Nature, 403, 853-858.

Myers, E. A., Bryson, R. W., Hansen, R. W., Aardema, M. L., Lazcano, D., \& Burbrink, F. T. (2019). Exploring Chihuahuan desert diversification in the gray-banded kingsnake, Lampropeltis alterna (Serpentes: Colubridae). Molecular Phylogenetics and Evolution, 131, 211-218.

Nadachowska-Brzyska, K., Li, C., Smeds, L., Zhang, G., \& Ellegren, H. (2015). Temporal dynamics of avian populations during pleistocene revealed by whole-genome sequences. Current Biology, 25(10), 1375-1380.

Nores, M. (1999). An alternative hypothesis for the origin of Amazonian bird diversity. Journal of Biogeography, 26, 475-485.

Oswald, J. A., Harvey, M. G., Remsen, R. C., Foxworth, D. U., Dittmann, D. L., Cardiff, S. W., \& Brumfield, R. T. (2019). Evolutionary dynamics of hybridization and introgression following the recent colonization of glossy ibis (Aves: Plegadis falcinellus) into the new world. Molecular Ecology, 28(7), 1675-1691.

Paradis, E., Claude, J., \& Strimmer, K. (2004). Ape: Analyses of phylogenetics and evolution in R language. Bioinformatics, 20(2), 289-290.

Patton, J. L., da Silva, M. N. F., Lara, M. C., \& Mustrangi, M. A. (1997). Diversity, differentiation, and the historical biogeography of nonvolant small mammals of the Neotropical forests. In W. F. 
Laurance \& R. O. B. Jr. (Eds.), Tropical Forest Remnants: Ecology, Management and Conservation of Fragmented Communities. Chicago, Illinois: University of Chicago Press.

Pérez-Escobar, O. A., Chomicki, G., Condamine, F. L., Karremans, A. P., Bogarín, D., Matzke, N. J., Silvestro, D., \& Antonelli, A. (2017). Recent origin and rapid speciation of Neotropical orchids in the world's richest plant biodiversity hotspot. New Phytologist, 215(2), 891-905. 201723782.

Polato, N. R., Gill, B. A., Shah, A. A., Gray, M. M., Casner, K. L., Barthelet, A., Messer, P. W., Simmons, M. P., Guayasamin, J. M., Encalada, A. C., Kondratieff, B. C., Flecker, A. S., Thomas, S. A., Ghalambor, C. K., Poff, N. L., Funk, W. C., \& Zamudio, K. R. (2018). Narrow thermal tolerance and low dispersal drive higher speciation in Tropical mountains. Proceedings of the National Academy of Sciences.

Potter, S., Xue, A. T., Bragg, J. G., Rosauer, D. F., Roycroft, E. J., \& Moritz, C. (2017). Pleistocene climatic changes drive diversification across a tropical savanna. Molecular Ecology, 27(2), 520532.

Prado, D. E. \& Gibbs, P. E. (1993). Patterns of species distributions in the dry seasonal forests of South America. Annals of the Missouri Botanical Garden, 80, 902-927.

Pupim, F., Sawakuchi, A., Almeida, R., Ribas, C., Kern, A., Hartmann, G., Chiessi, C., Tamura, L., Mineli, T., Savian, J., Grohmann, C., Bertassoli, D., Stern, A., Cruz, F., \& Cracraft, J. (2019). Chronology of terra firme formation in Amazonian lowlands reveals a dynamic Quaternary landscape. Quaternary Science Reviews, 210, 154 - 163.

Raikow, R. J. (1994). A phylogeny of the woodcreepers (Dendrocolaptinae). The Auk: Ornithological Advances, 111(1), 104-114. 
Rambaut, A., Drummond, A. J., Xie, D., Baele, G., \& Suchard, M. A. (2018). Posterior summarization in bayesian phylogenetics using tracer 1.7. Systematic Biology, 67(5), 901-904. Remsen Jr., J. V., 0., O. R., Schmitt, C. G., \& Schmitt, D. C. (1991). Zoogeography and geographic variation of Platyrinchus mystaceus in Bolivia and Peru, and the Circum-Amazonian distribution pattern. Ornitologia Neotropical, 2, 77-83.

Ribas, C. C., Moyle, R. G., Miyaki, C. Y., \& Cracraft, J. (2007). The assembly of montane biotas: linking Andean tectonics and climatic oscillations to independent regimes of diversification in pionus parrots. Proceedings of the Royal Society of London B: Biological Sciences, 274, 23992408.

Ribas, C. C., Aleixo, A., Gubili, C., d'Horta, F. M., Brumfield, R. T., \& Cracraft, J. (2018). Biogeography and diversification of Rhegmatorhina (Aves: Thamnophilidae): Implications for the evolution of Amazonian landscapes during the Quaternary. Journal of Biogeography, 45(4), 917928.

Richardson, J. E., Pennington, R. T., Pennington, T. D., \& Hollingsworth, P. M. (2001). Rapid diversification of a species-rich genus of Neotropical rain forest trees. Science, 293(5538), 22422245.

Richardson, J. E. \& Pennington, R. T. (2016). Editorial: Origin of tropical diversity: From clades to communities. Frontiers in Genetics, 7, 186.

Rincon-Sandoval, M., Betancur-R, R., \& Maldonado-Ocampo, J. A. (2019). Comparative phylogeography of trans-andean freshwater fishes based on genome-wide nuclear and mitochondrial markers. Molecular Ecology, 28(5), 1096-1115.

Rivas-Martínez, S. \& Tovar, O. (1983). Síntesis biogeográfica de los Andes. Collectanea Botanica, 14, 515-521. 
Rocha, D. G. d. \& Kaefer, I. L. (2019). What has become of the refugia hypothesis to explain biological diversity in Amazonia? Ecology and Evolution, 9(7), 4302-4309.

Rull, V. (2011). Neotropical biodiversity: timing and potential drivers. Trends in Ecology and Evolution, 26(10), 508-513.

Salo, J. (1987). Pleistocene forest refuges in the amazon: evaluation of the biostratigraphical, lithostratigraphical and geomorphological data. Annales Zoologici Fennici, 24(3), 203-211.

Sartorato Zanchetta, L., Gomes Rocha, R., \& Reis Leite, Y. L. (2019). Comparative phylogeography and demographic history of two marsupials of the Atlantic forest in eastern Brazil. Journal of Zoological Systematics and Evolutionary Research, 0(0).

Savit, A. Z. \& Bates, J. M. (2015). Right around the amazon: the origin of the Circum-Amazonian distribution in Tangara cayana. Folia Zoologica, 64(3), 273-283.

Sick, H. (1967). Rios e enchentes na Amazônia como obstáculo para a avifauna. Atas Simp. Sobre a Biota Amazonica, 5, 495-520.

da Silva, J. M. C., de Sousa, M. C., \& Castelletti, C. H. M. (2004). Areas of endemism for passerine birds in the Atlantic Forest, South America. Global Ecology and Biogeography, 13(1), 85-92.

Silva, C. R., Ribas, C. C., Da Silva, M. N. F., Leite, R. N., Catzeflis, F., Rogers, D. S., \& De Thoisy, B. (2018). The role of pleistocene climate change in the genetic variability, distribution and demography of Proechimys cuvieri and P. guyannensis (Rodentia: Echimyidae) in northeastern Amazonia. PLOS ONE, 13(12), 1-20.

Smith, B. T., Ribas, C. C., Whitney, B. M., nos, B. E. H.-B., \& Klicka, J. (2013). Identifying biases at different spatial and temporal scales of diversification: a case study in the Neotropical parrotlet genus Forpus. Molecular Ecology, 22, 483-494. 
Tello, J. G., Raposo, M., Bates, J. M., Bravo, G. A., Cadena, C. D., \& Maldonado-Coelho, M. (2014). Reassessment of the systematics of the widespread Neotropical genus Cercomacra (Aves: Thamnophilidae). Zoological Journal of the Linnean Society, 170, 546-565.

Thomaz, A. T., Malabarba, L. R., Bonatto, S. L., \& Knowles, L. L. (2015). Testing the effect of palaeodrainages versus habitat stability on genetic divergence in riverine systems: study of a Neotropical fish of the Brazilian coastal Atlantic Forest. Journal of Biogeography, 42(12), 23892401.

Thomé, M. T. C., Zamudio, K. R., Giovanelli, J. G., Haddad, C. F., Jr., F. A. B., \& Alexandrino, J. (2010). Phylogeography of endemic toads and post-Pliocene persistence of the Brazilian Atlantic Forest. Molecular Phylogenetics and Evolution, 55(3), 1018 - 1031.

Todd, W. E. C. (1916). On Dysithamnus mentalis and its allies. Bulletin American Museum of Natural History, 25, 533-558.

Trujillo-Arias, N., Dantas, G., Arbeláez-Cortés, E., Naoki, K., Gómez, M. I., Santos, F. R., Miyaki, C. Y., Aleixo, A., Tubaro, P. L., \& Cabanne, G. S. (2017). The niche and phylogeography of a passerine reveal the history of biological diversification between the Andean and the Atlantic forests. Molecular Phylogenetics and Evolution, 112, 107 - 121.

Vanzolini, P. \& Williams, E. E. (1970). South American anoles: The geographic differentiation and evolution of the anolis Chrysolepis species group (Sauria, Iguanidae), volume 19 of Arquivos de zoologia. Museu de Zoologia.

Vuilleumier, B. S. (1971). Pleistocene changes in the fauna and flora of South America. Science, New Series, 173(3999), 771-780.

Wallace, A. R. (1854). On the monkeys of the Amazon. Annals and Magazine of Natural History, 14(84), 451-454. 
Weigend, M. (2002). Observations on the biogeography of the Amotape-Huancabamba Zone in northern Peru. The Botanical Review, 68(1), 38-54.

Weir, J. T. \& Schluter, D. (2008). Calibrating the avian molecular clock. Molecular Ecology, 17, $2321-2328$.

Werneck, F. P., Costa, G. C., Colli, G. R., Prado, D. E., \& Sites Jr, J. W. (2011). Revisiting the historical distribution of seasonally dry tropical forests: new insights based on palaeodistribution modelling and palynological evidence. Global Ecology and Biogeography, 20(2), 272-288.

Zarza, E., Connors, E. M., Maley, J. M., Tsai, W. L., Heimes, P., Kaplan, M., \& McCormack, J. E. (2018). Combining ultraconserved elements and mtdna data to uncover lineage diversity in a Mexican highland frog (Sarcohyla; hylidae). PeerJ, 6, e6045.

Zimmer, K. \& Isler, M. L. (2019a). Variable Antshrike (Thamnophilus caerulescens). In J. del Hoyo, A. Elliott, J. Sargatal, D. Christie, \& E. de Juana (Eds), Handbook of the Birds of the World Alive. Lynx Editions, Barcelona.

Zimmer, K. \& Isler, M.L. (2019b). Chestnut-backed Antshrike (Thamnophilus palliatus). In: del Hoyo, J., Elliott, A., Sargatal, J., Christie, D.A. \& de Juana, E. (eds.). Handbook of the Birds of the World Alive. Lynx Edicions, Barcelona. (retrieved from https://www.hbw.com/node/56666 on 24 July 2019).

Zink, R. M. (2002). Methods in comparative phylogeography, and their application to studying evolution in the North American aridlands. Integrative \& Comparative Biology, 42, 953-959. 


\section{Appendix (Chapter II)}

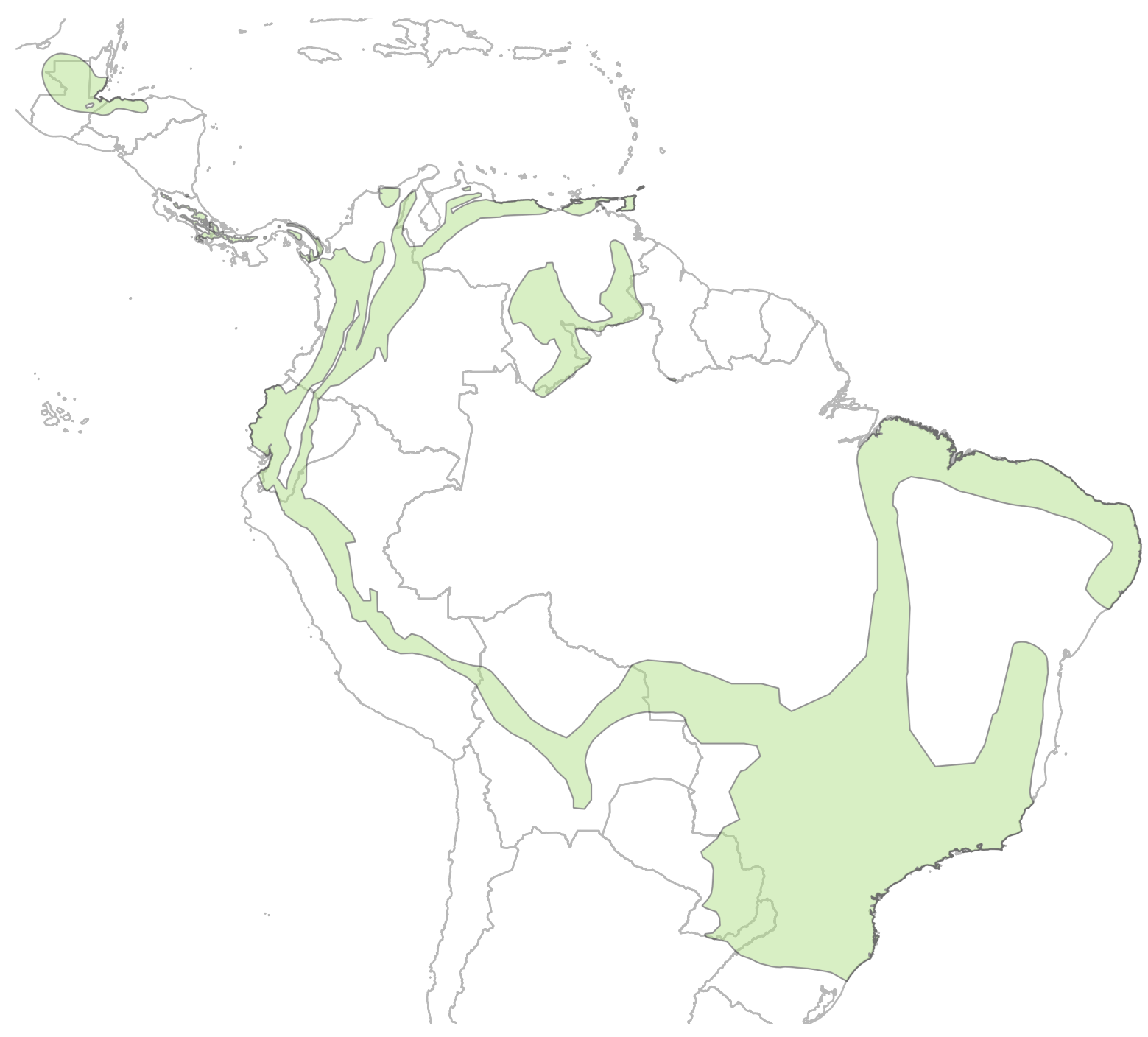

Figure 1. Distribution of Dysithamnus mentalis (BirdLife International, 2019), a circum-Amazonian species (sensu Remsem et al., 1991). 

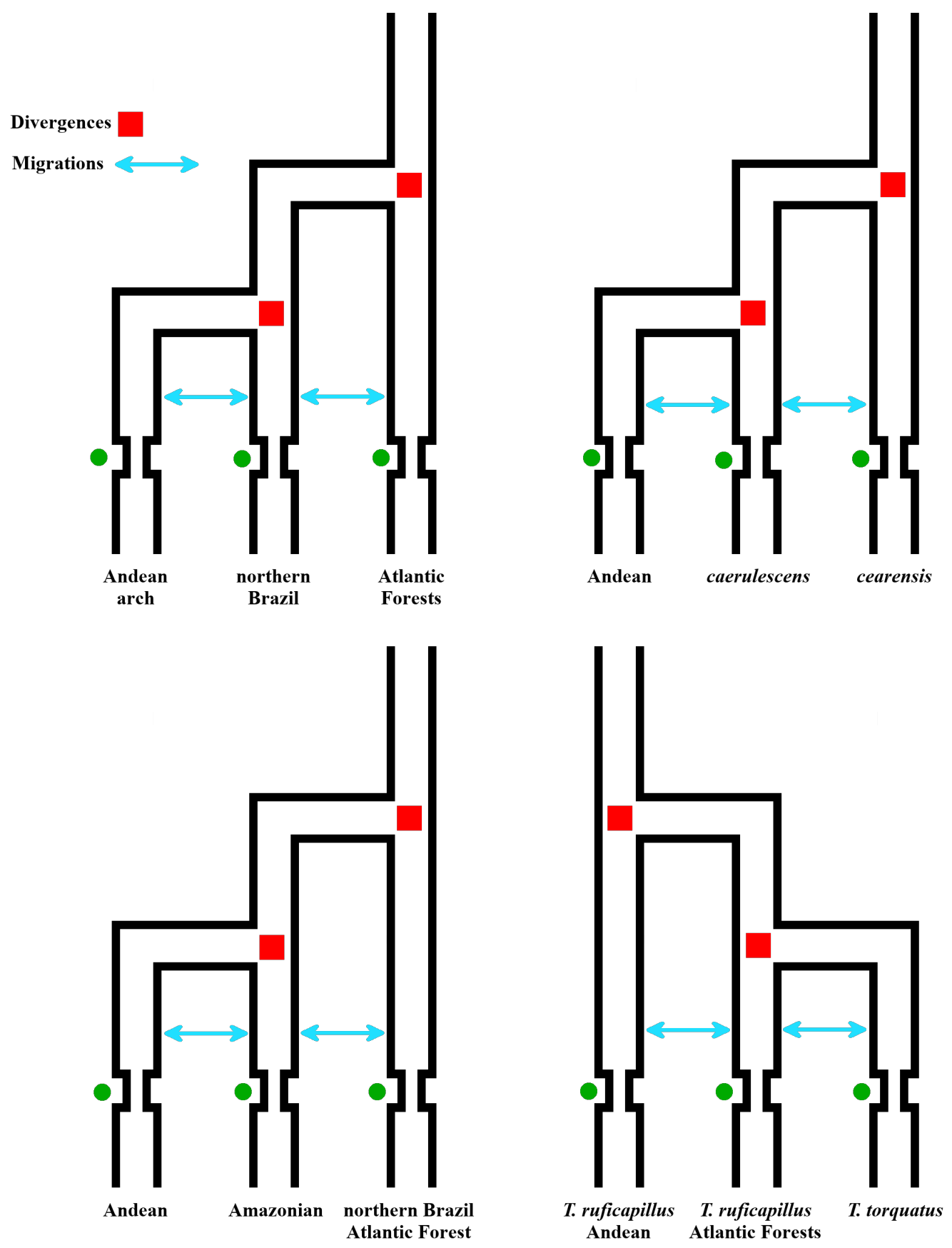

Figure 2. Basic models tested for the four species of Thamnophilidae. Divergence times (red square). Events of migration (blue arrows). Bottleneck events (green circles). All models tested were variations of these basic models, these variations consisted in change number of events and direction of the migrations.. 

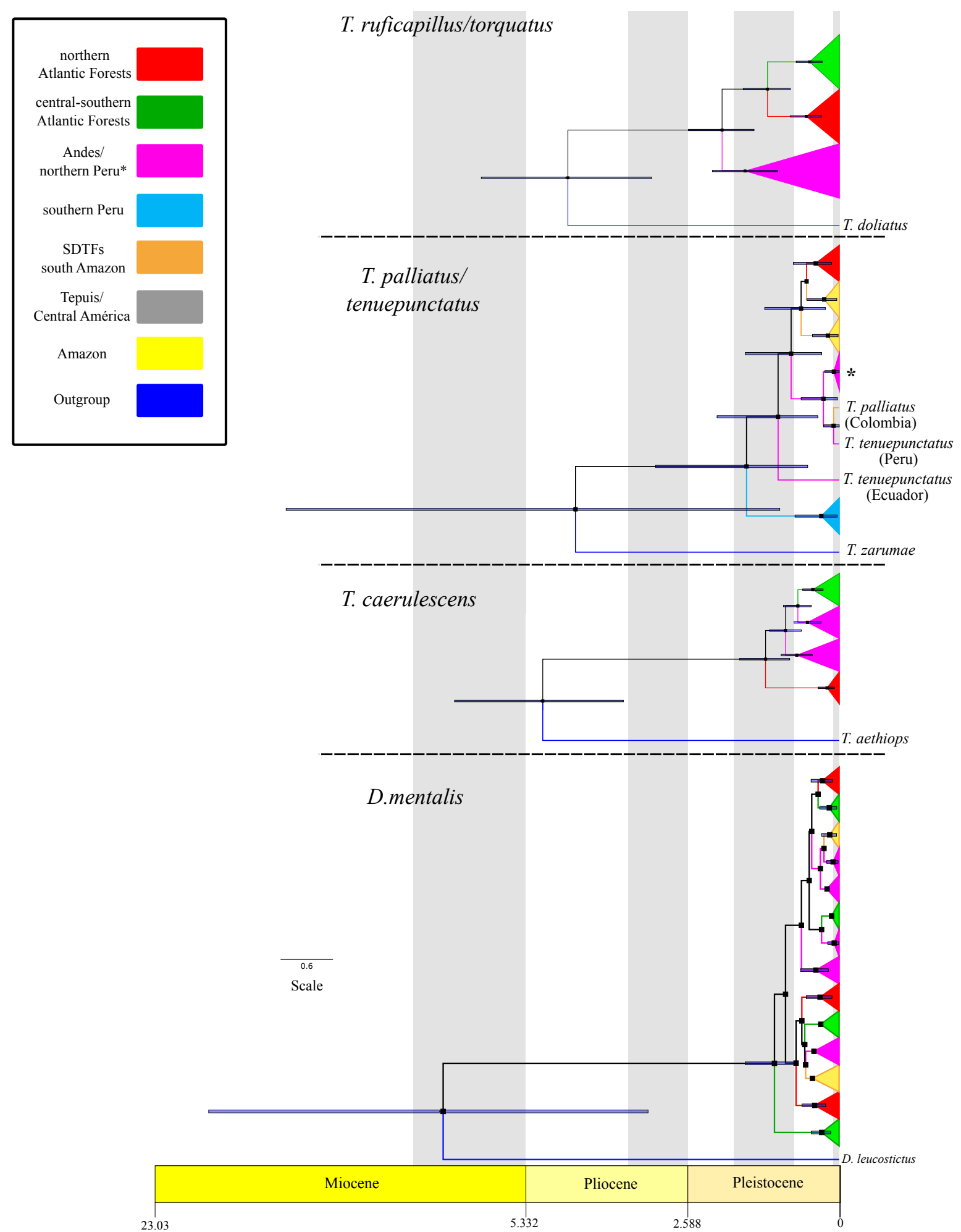

Figure 3a. Divergence times among intraspecific lineages for the four species of Thamnophilidae. Blue bars are confidence intervals of divergence time estimates. Collapsed clades indicate geographical clusters identified by DAPC/sNMF: Red: northern Atlantic Forest; Green: central-southern Atlantic Forest; Pink: Andean (or central Andean); Brown-Yellow: forests southeast of the Amazon; Pale-Blue: southern Peru-Bolivia region; Blue: Outgroups. 


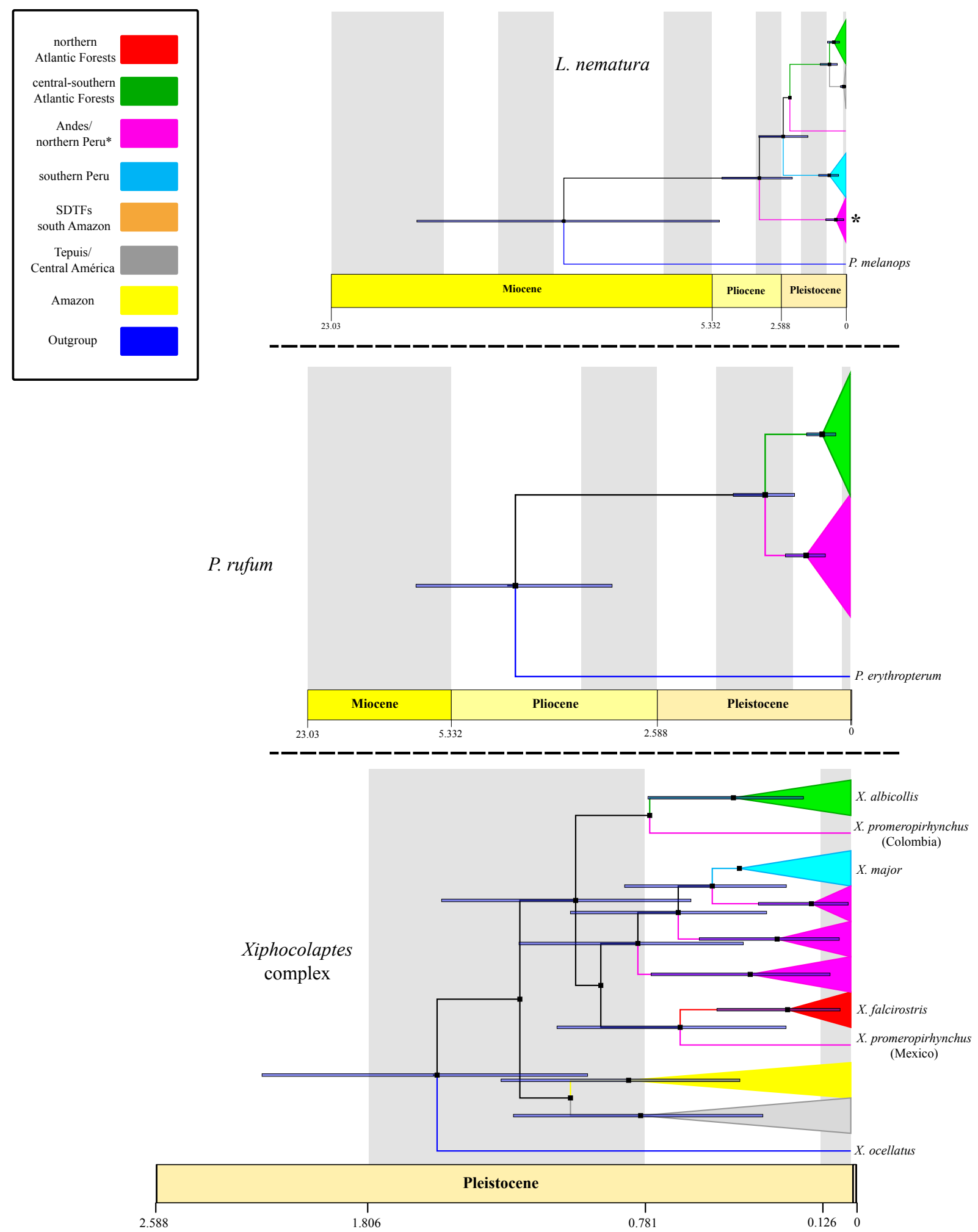

Figure 3b. Divergence times among intraspecific lineages for L. nematura, P. rufum, and the Xiphocolaptes complex. Blue bars are confidence intervals of divergence time estimates. Collapsed clades indicate geographical clusters identified by DAPC/sNMF: Red: northern Atlantic Forest; Green: central-southern Atlantic Forest; Pink: Andean (or central Andean); Brown-Yellow: forests southeast of the Amazon; Pale-Blue: southern Peru-Bolivia region; Gray: Tepuis-Central America; Yellow: Amazonian region; Blue: Outgroups. 

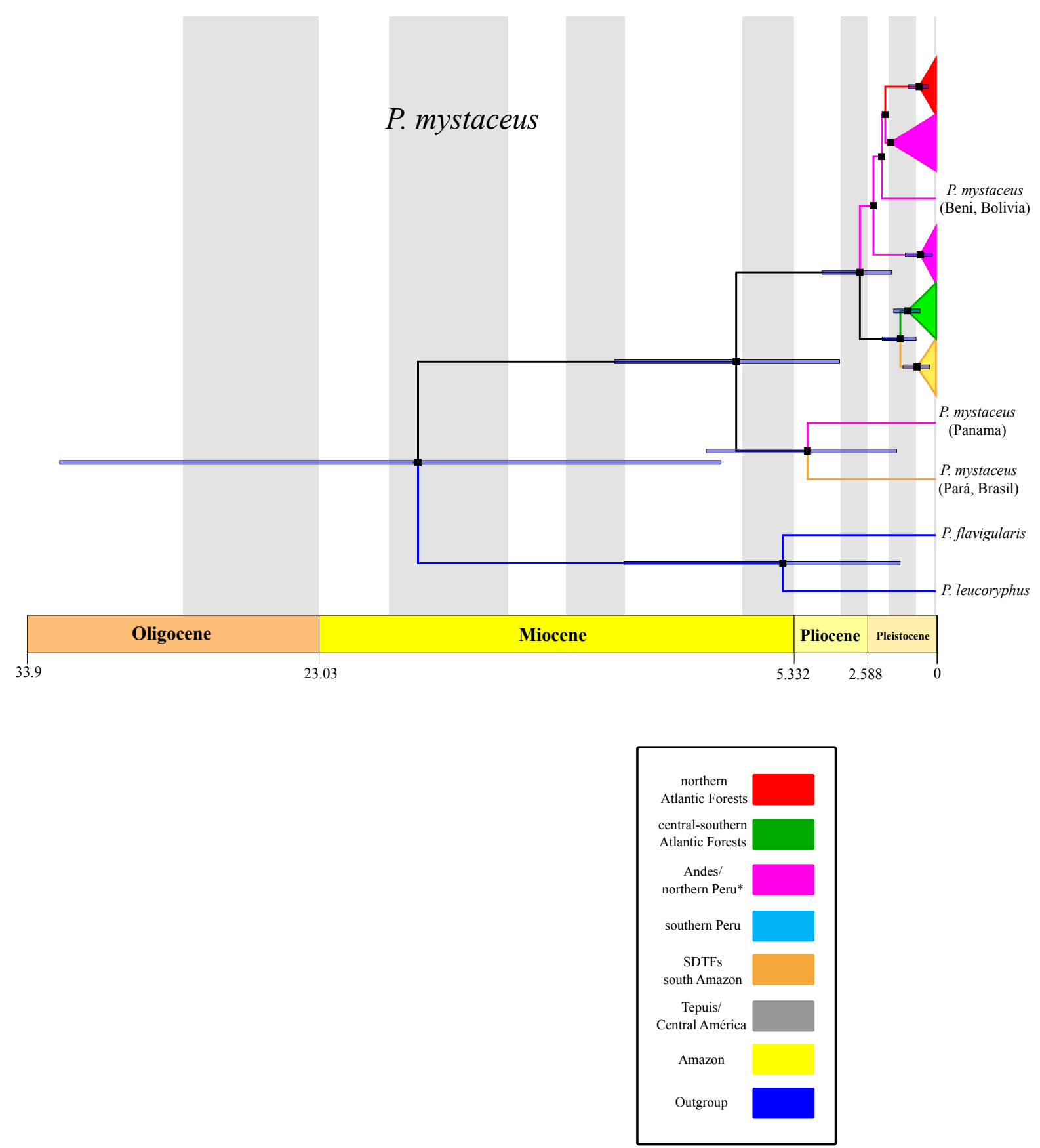

Figure 3c. Divergence times among intraspecific lineages for $P$. mystaceus. Blue bars are confidence intervals of divergence time estimates. Collapsed clades indicate geographical clusters identified by DAPC/sNMF: Red: northern Atlantic Forest; Green: central-southern Atlantic Forest; Pink: Andean (or central Andean); Brown-Yellow: forests southeast of the Amazon; Blue: Outgroups. 


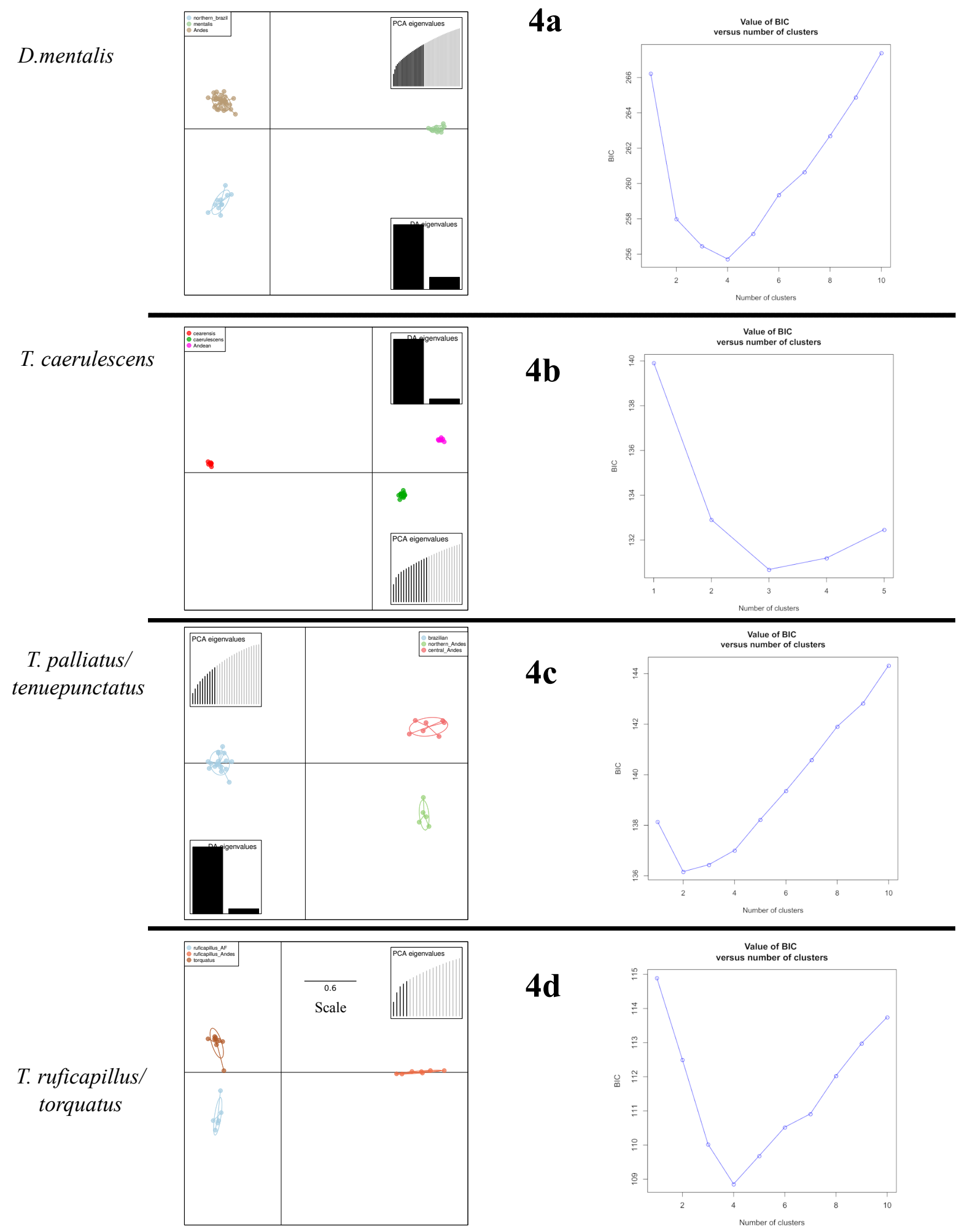

Figure 4. Results of DAPC and find.cluster() analyses for the genomic data (UCEs) of the Thamnophilid species. (a) D. mentalis. (b) T. caerulescens. (c) T. palliatus/tenuepunctatus complex. (d) T. ruficapillus/torquatus complex. 
L. nematura

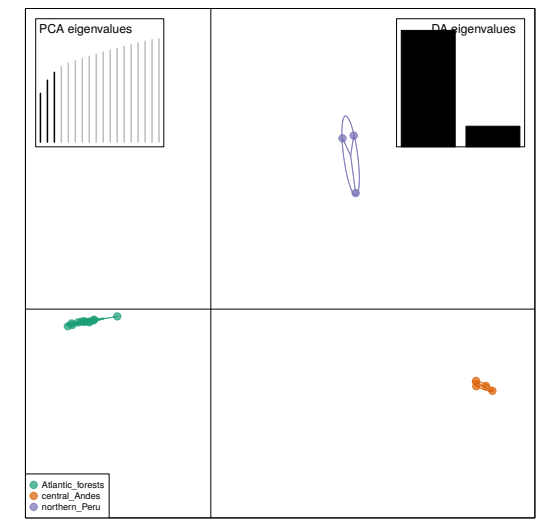

P. rufum

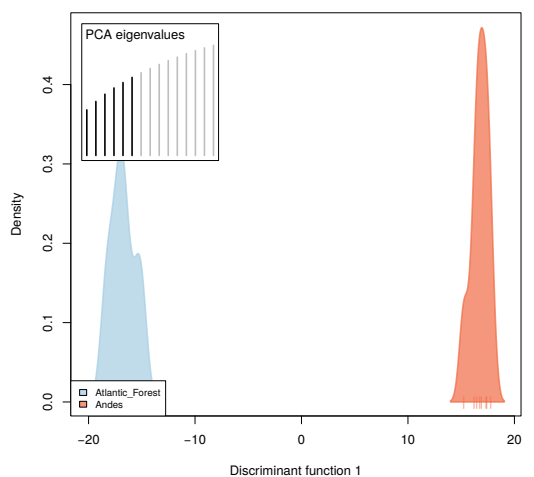

P. mystaceus
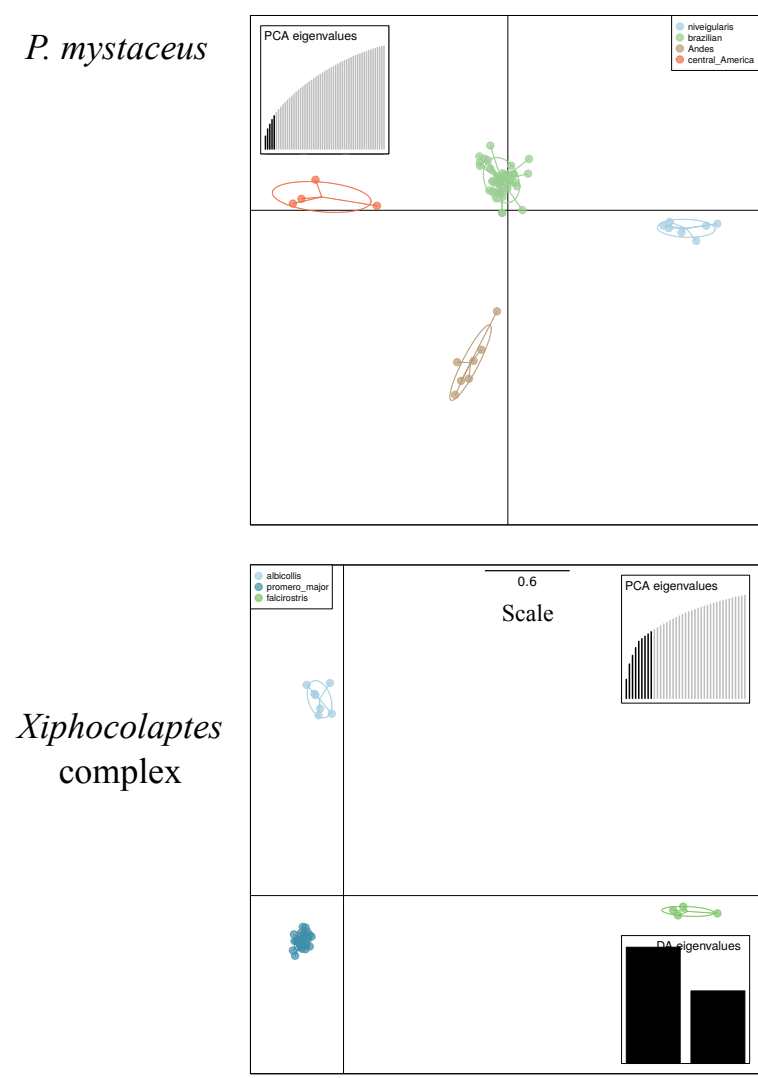

$4 e$

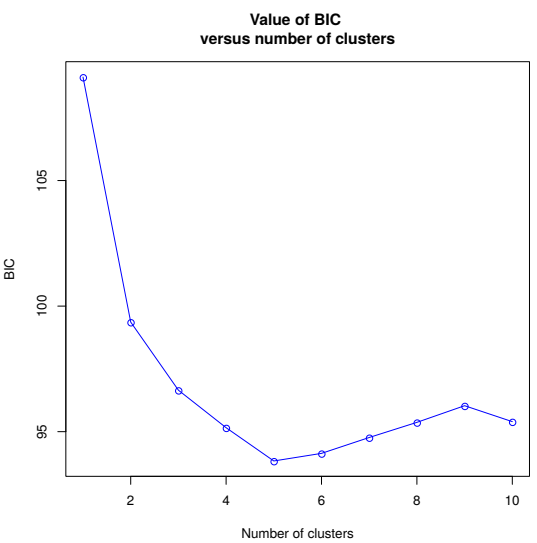

4f

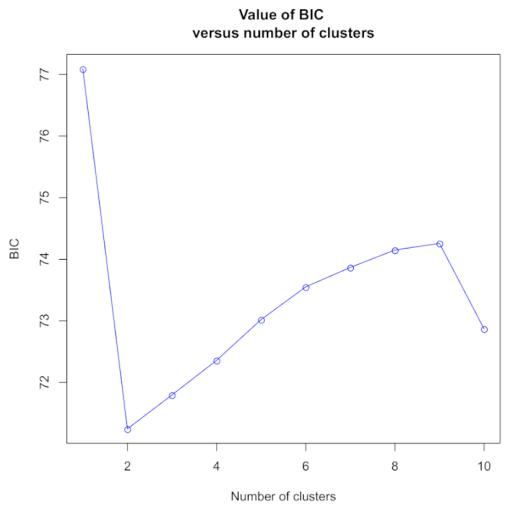

49

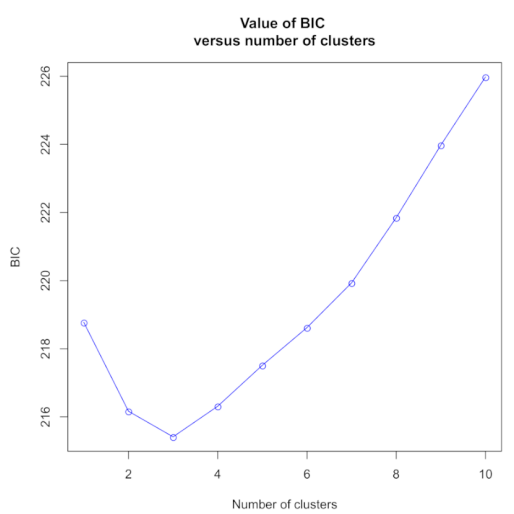

4h

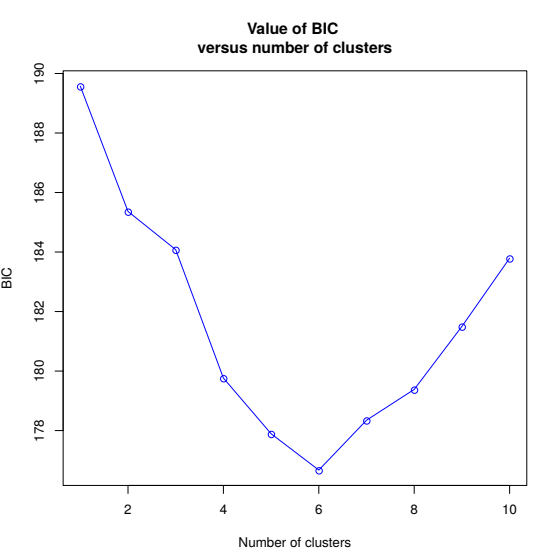

Figure 4. Results of DAPC and find.cluster() analyses for the genomic data (UCEs). (e) $L$. nematura. (f) P. rufum. (g) P. mystaceus. (h) Xiphocolaptes complex. 

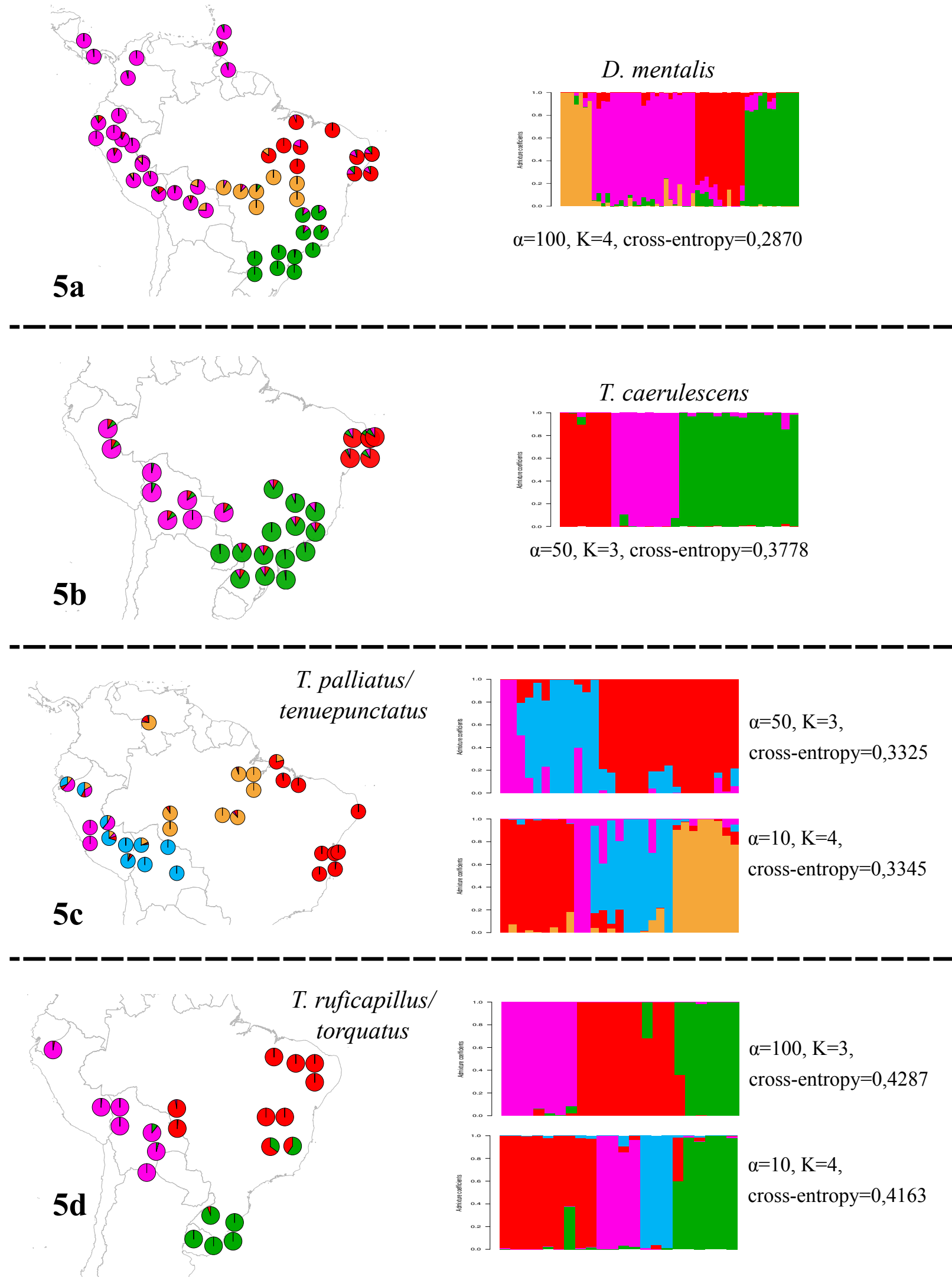

Figure 5. Results of sNMF analysis for the genomic data (UCEs) of the Thamnophilid species. (e) D. mentalis. (f) T. caerulescens. (g) T. palliatus/tenuepunctatus. (h) $T$. ruficapillus/torquatus. 

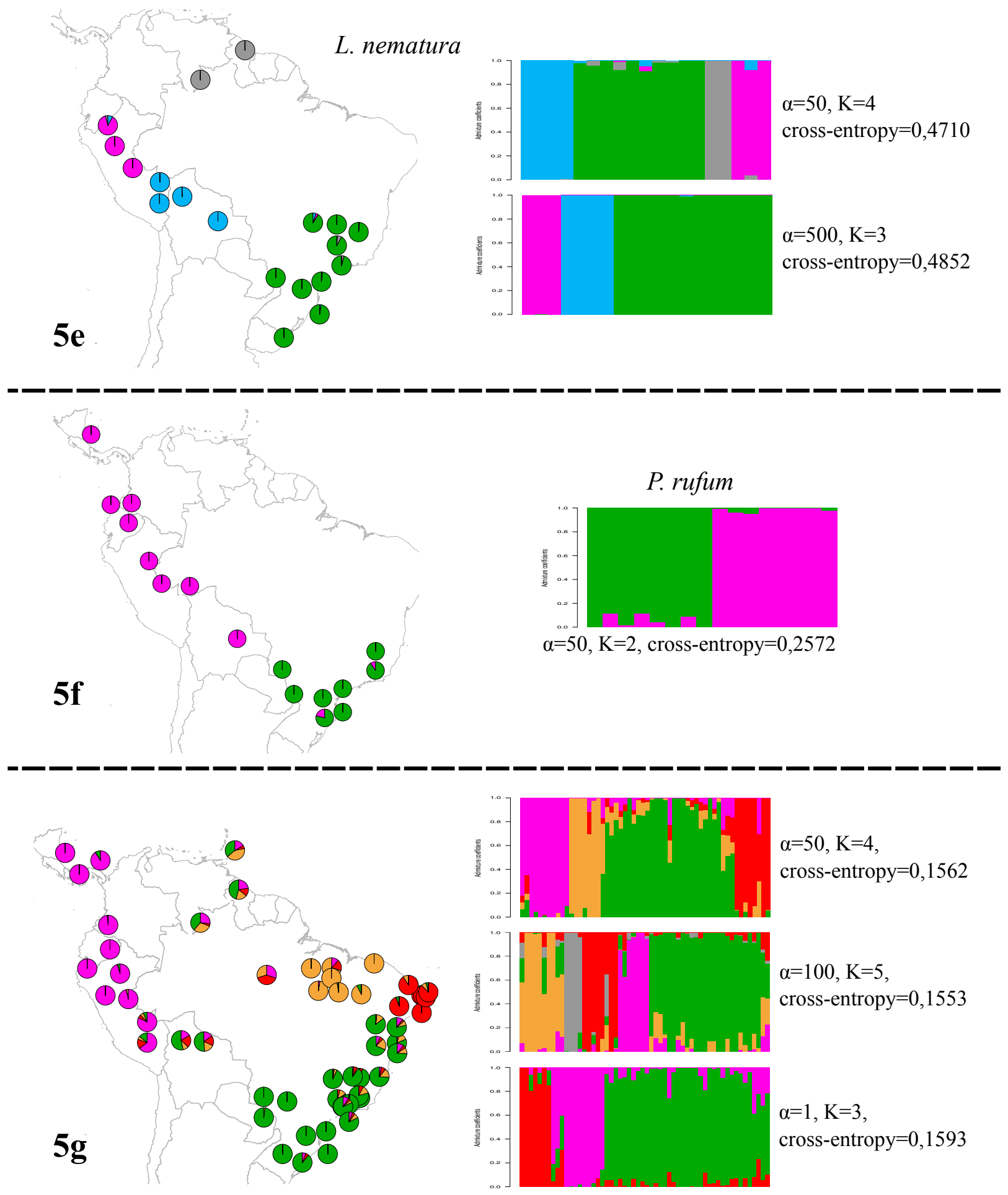

Figure 5. Results of sNMF analysis for the genomic data (UCEs). (e) L. nematura. (f) $P$. rufum. (g) P. mystaceus. 

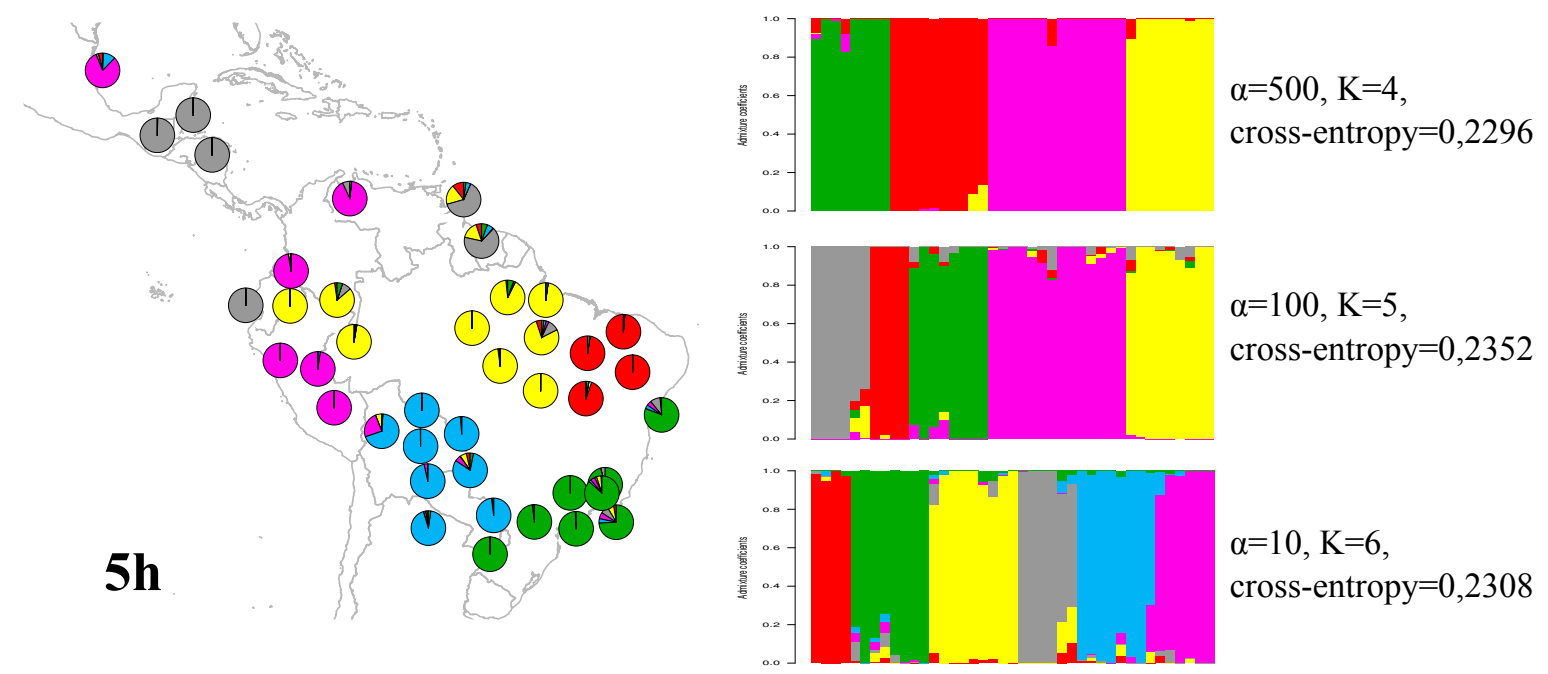

Figure 5. Results of sNMF analysis for the genomic data (UCEs). (h) Xiphocolaptes complex. 

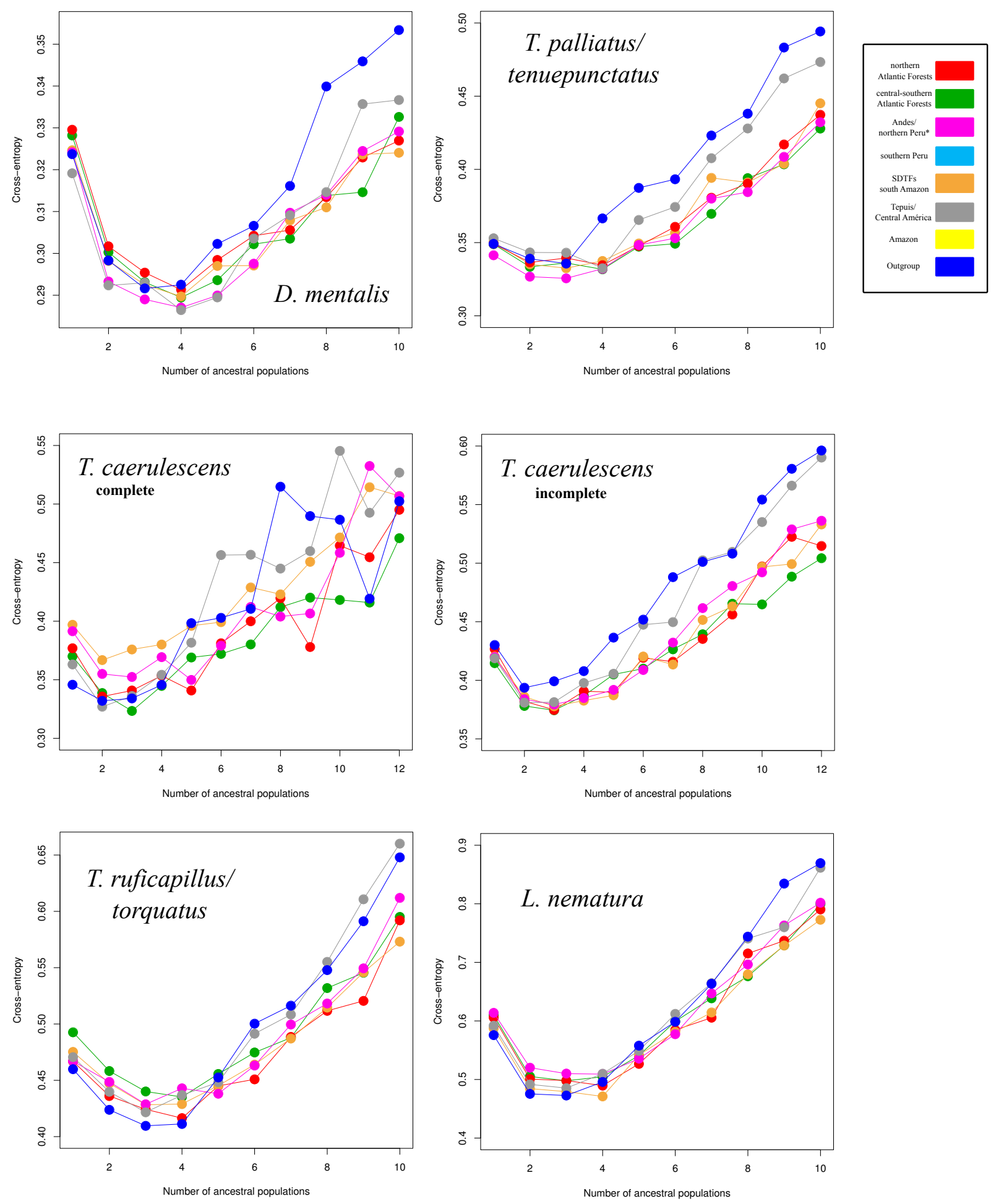

Figure 6a. Values of the cross-entropy criterion for the sNMF runs (six $\boldsymbol{\alpha}$ values). Green: $\alpha=1$; Red: $\alpha=10$; Brown-Yellow: $\alpha=50$; Pink: $\alpha=100$; Gray: $\alpha=500$; Blue: $\alpha=1000$. 

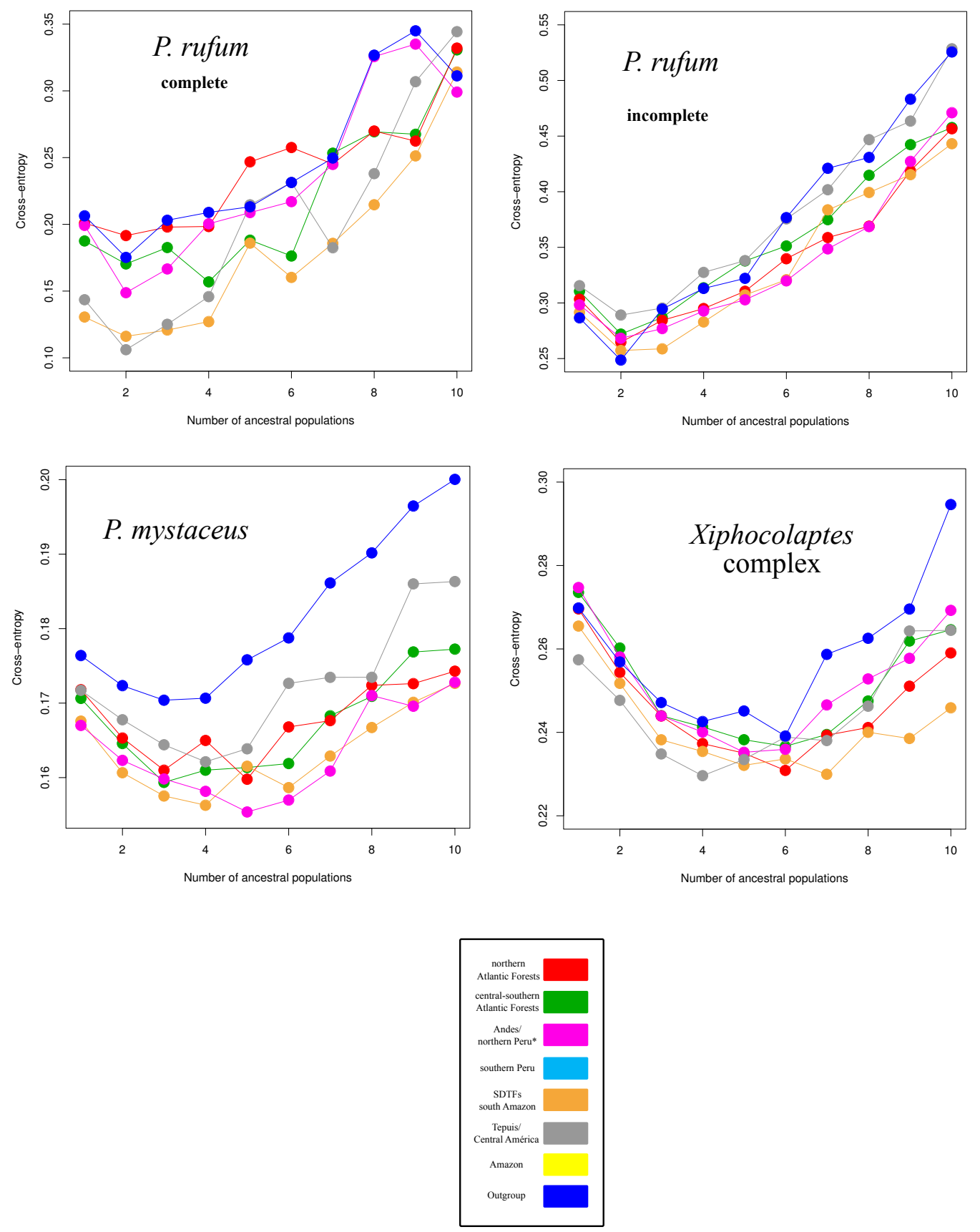

Figure $6 \mathbf{b}$. Values of the cross-entropy criterion for the sNMF runs ( $\operatorname{six} \boldsymbol{\alpha}$ values). Green: $\alpha=1$; Red: $\alpha=10$; Brown-Yellow: $\alpha=50$; Pink: $\alpha=100$; Gray: $\alpha=500$; Blue: $\alpha=1000$. 


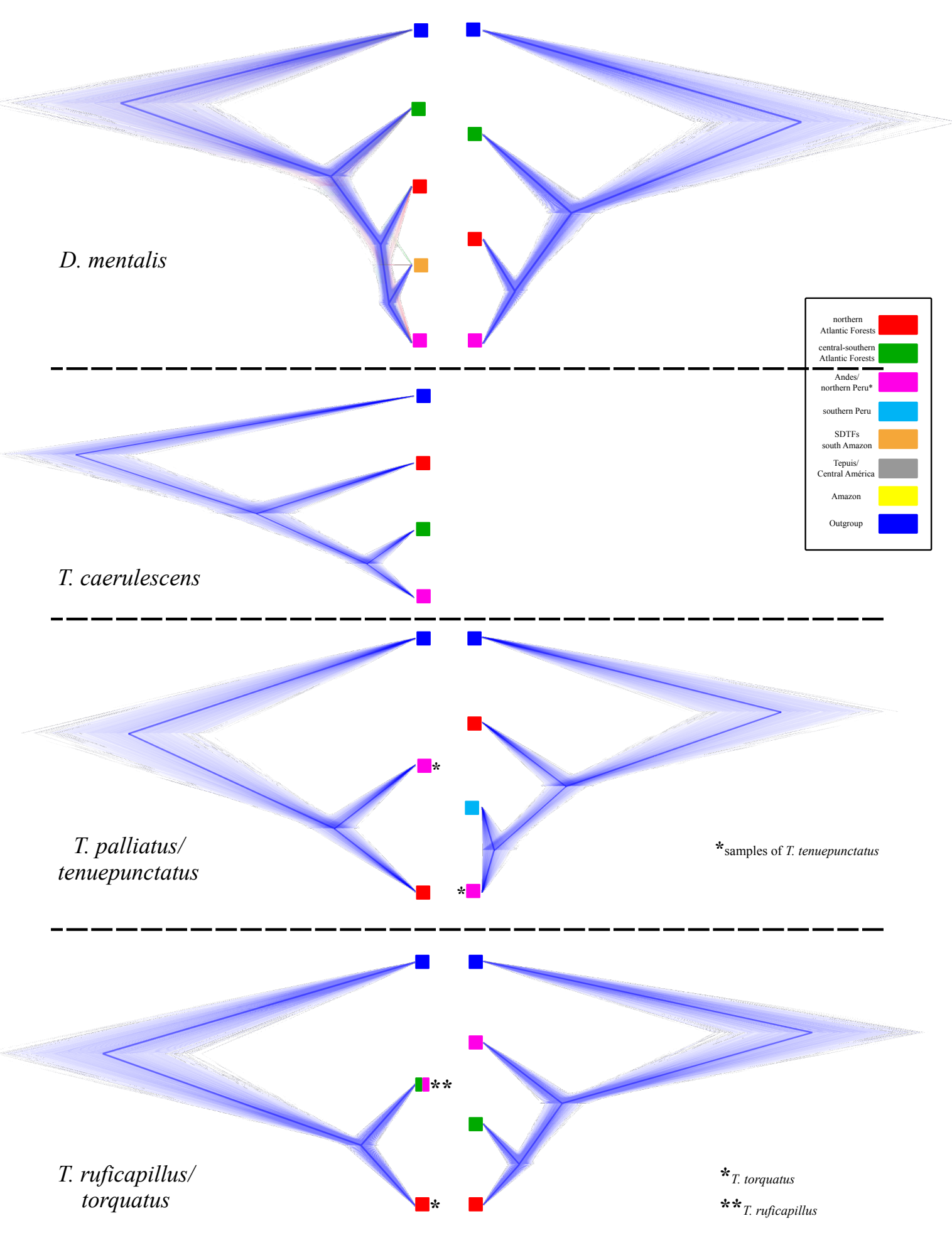

Figure 7a. Species trees inferred by SNAPP for the thamnophilid taxa data. Red: northern Atlantic Forest; Green: central-southern Atlantic Forest; Pink: Andean (or central Andean); Brown-Yellow: forests southeast of the Amazon; Pale-Blue: southern Peru-Bolivia region; Blue: Outgroups. 

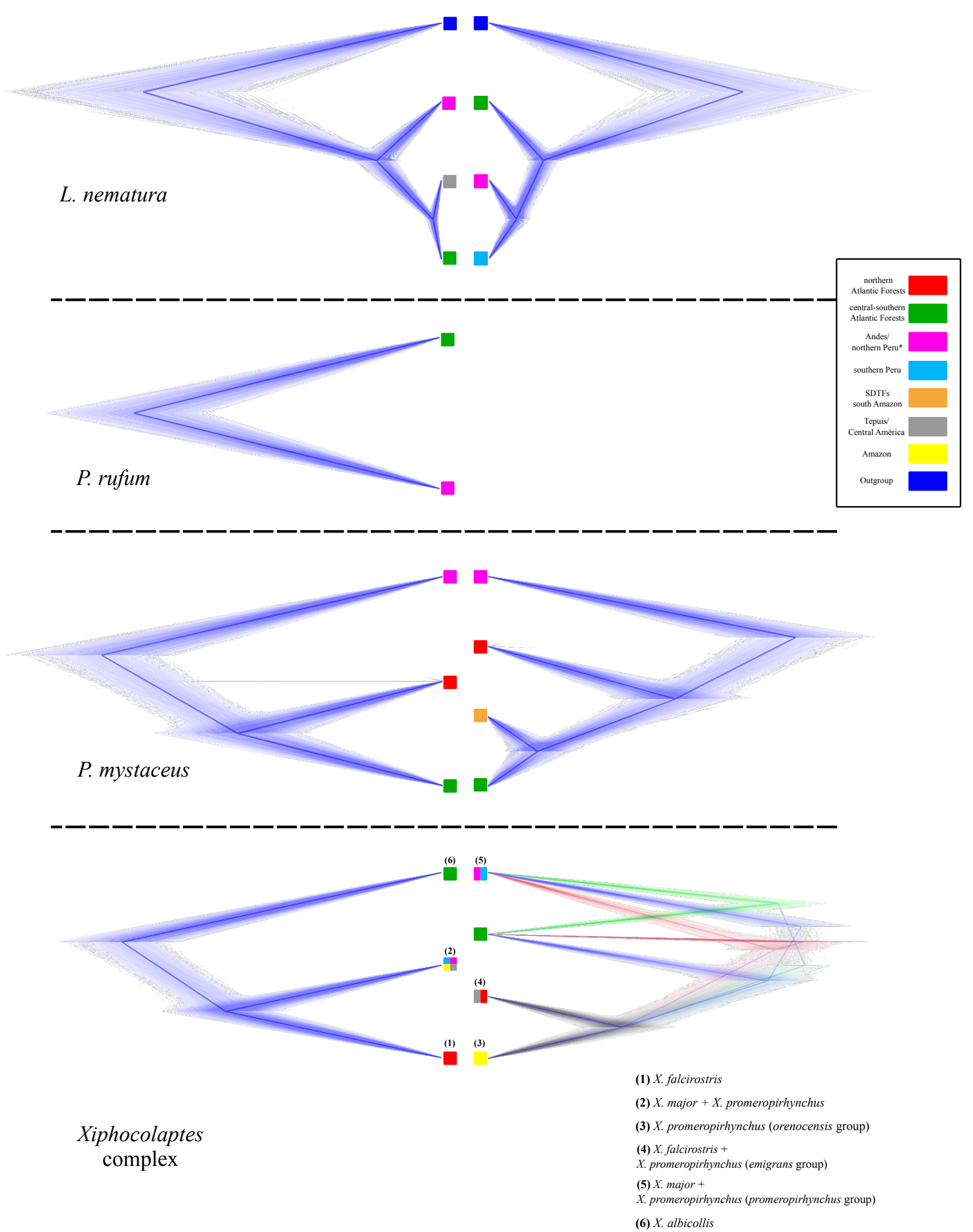

Figure 7b. Species trees inferred by SNAPP for the thamnophilid taxa data. Red: northern Atlantic Forest; Green: central-southern Atlantic Forest; Pink: Andean (or central Andean); Brown-Yellow: forests southeast of the Amazon; Pale-Blue: southern Peru-Bolivia region; Blue: Outgroups. Numbers in the figures represents the species in the Xiphocolaptes complex. 

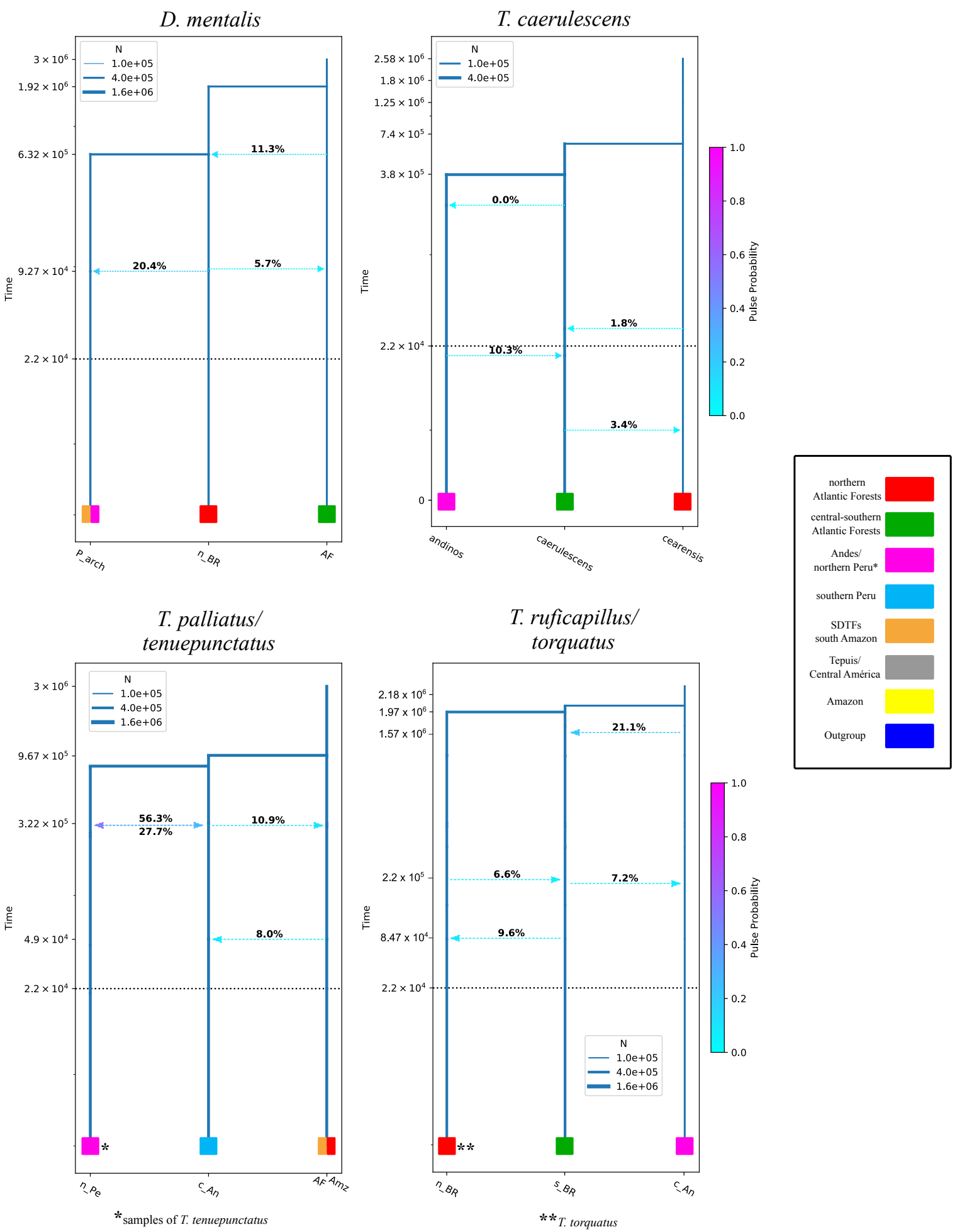

Figure 8. Best models inferred by momi2 for the foyr thamnophilid taxa. Red: northern Atlantic Forest; Green: central-southern Atlantic Forest; Pink: Andean (or central Andean); Brown-Yellow: forests southeast of the Amazon; Pale-Blue: southern Peru-Bolivia region. 


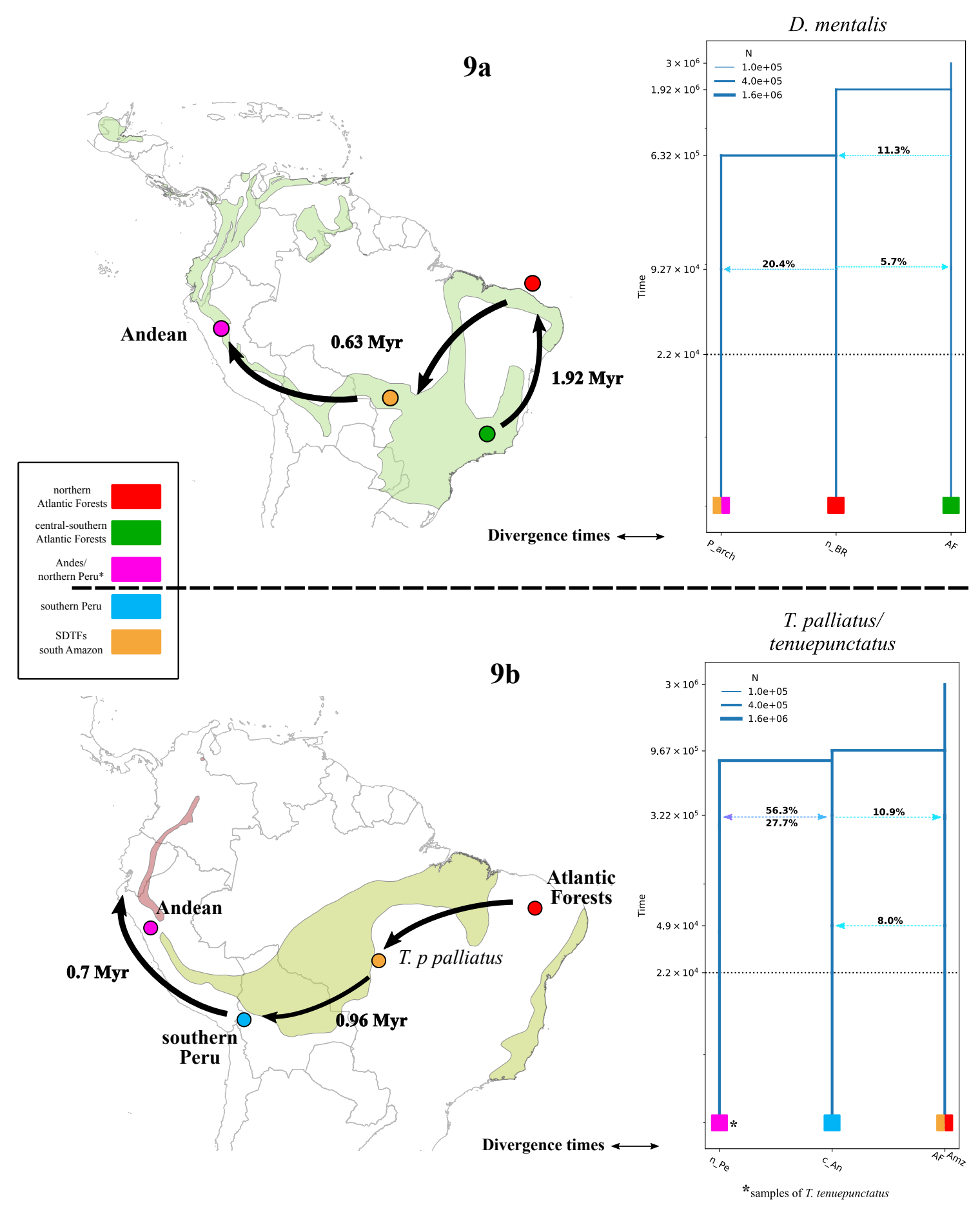

Figure 9. Plausible scenarios of diversification and migration pulses inferred by momi2 for the D. mentalis and the T. palliatus/teunuepunctatus complex. Red: northern Atlantic Forest; Green: central-southern Atlantic Forest; Pink: Andean (or central Andean); BrownYellow: forests southeast of the Amazon; Pale-Blue: southern Peru-Bolivia region. 

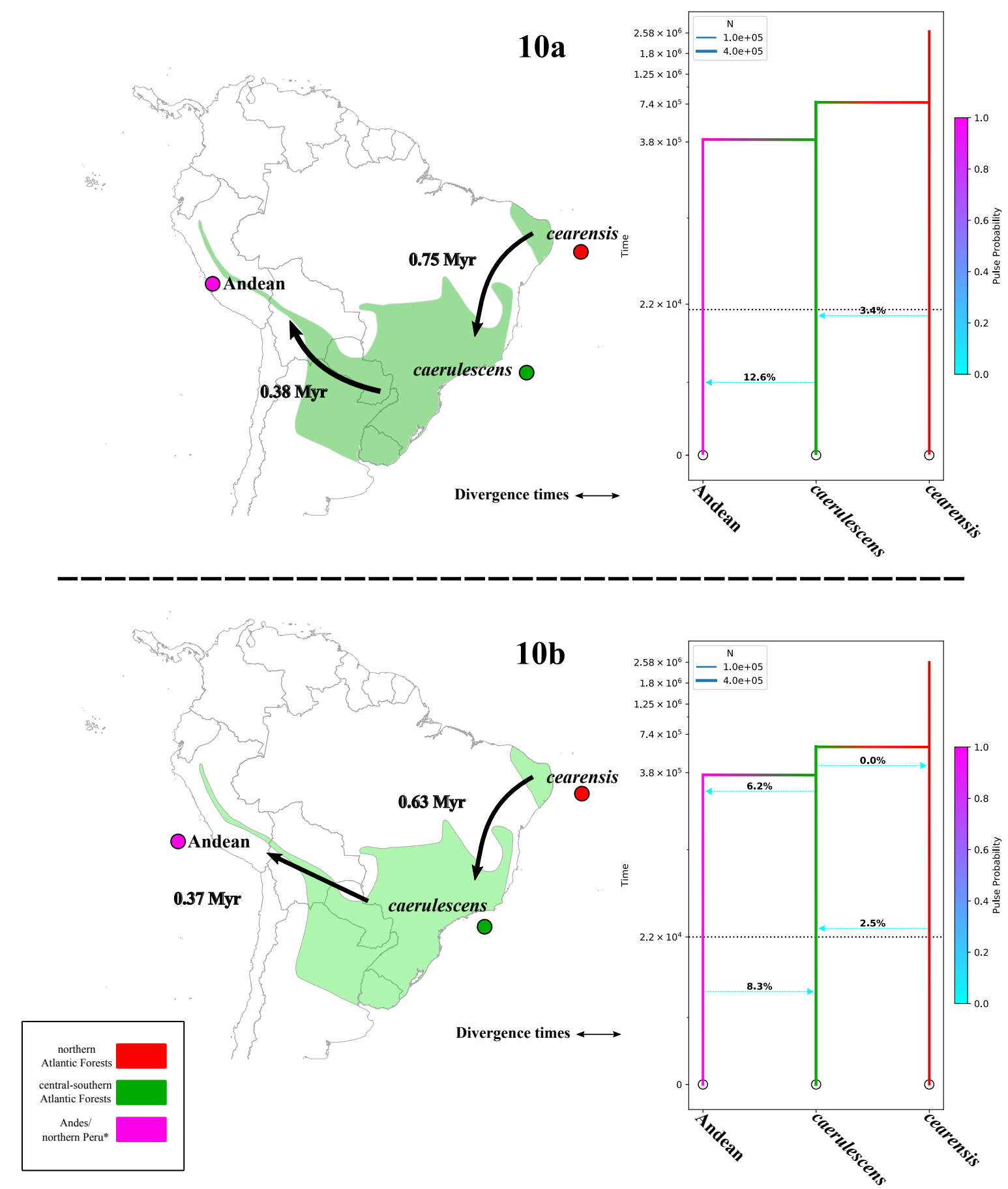

Figure 10. Plausible scenarios of diversification and migration pulses inferred by momi2 for T. caerulescens. (a) Complete matrix of SNPs (324 loci). (b) Incomplete matrix of SNPs (2,036 loci). Red: northern Atlantic Forest; Green: central-southern Atlantic Forest; Pink: Andean (or central Andean) region. 


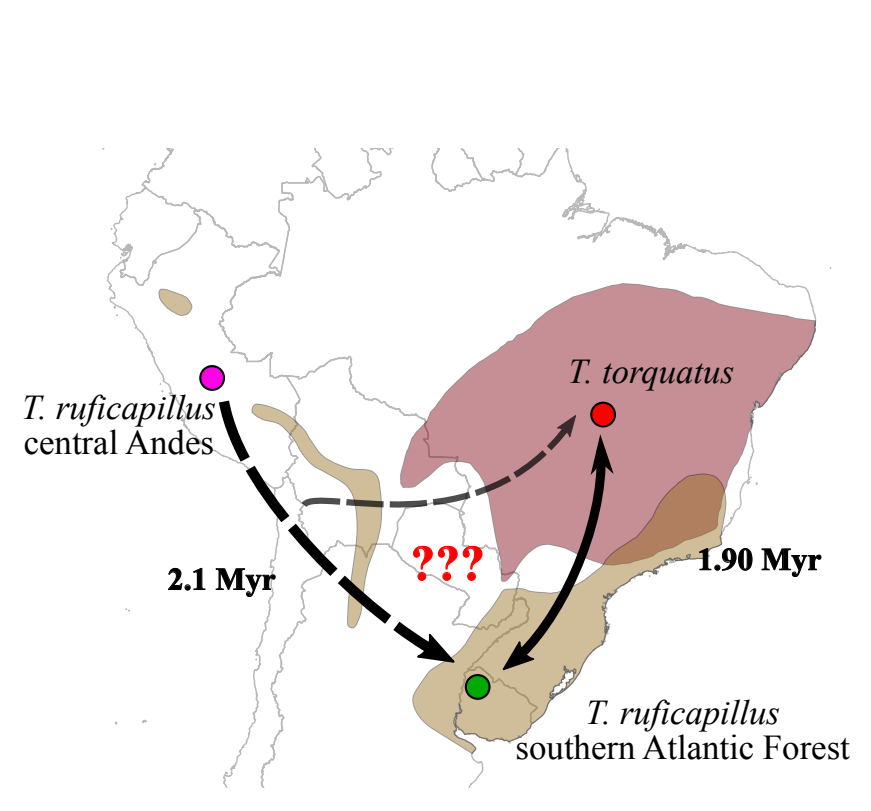

Divergence times
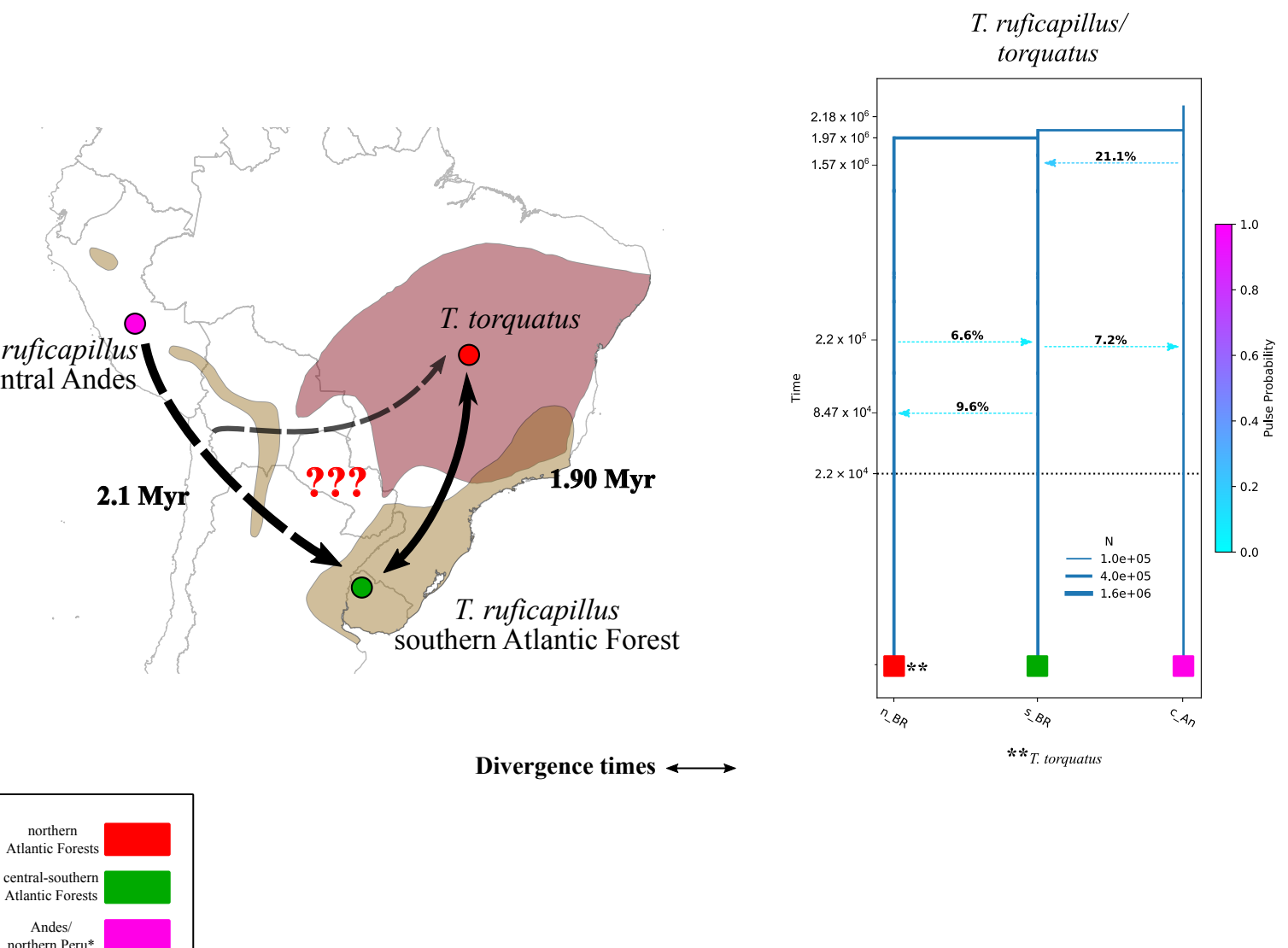

Figure 11. Plausible scenarios of diversification and migration pulses inferred by momi2 for T. ruficapillus/tenuepunctatus complex. Red: northern Atlantic Forest; Green: centralsouthern Atlantic Forest; Pink: Andean (or central Andean) region. 


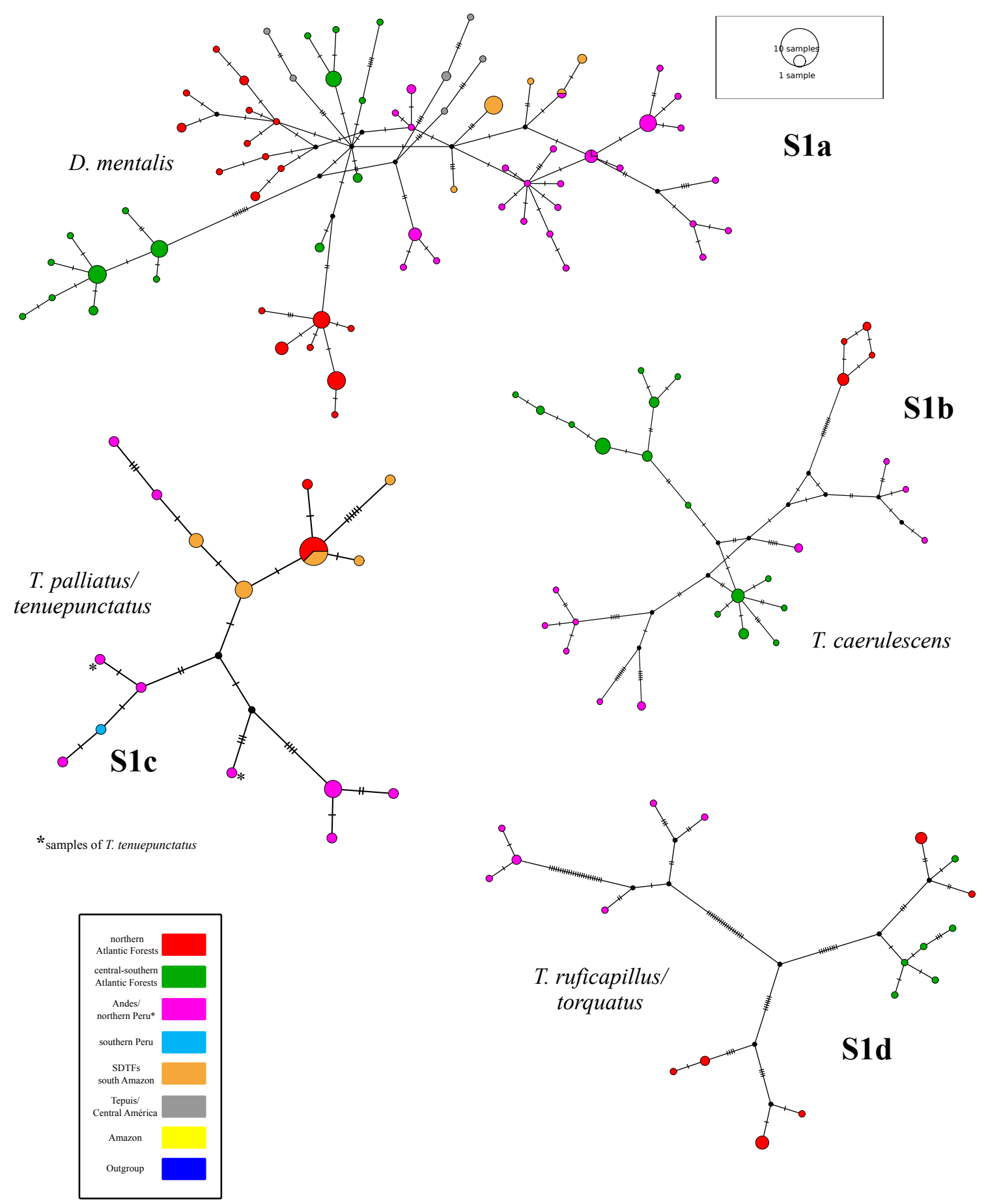

Figure S1. median-joining network depicting relationships among the haplotypes in the thamnophilid taxa. (a) D. mentalis. (b) T. caerulescens. (c) T. palliatus/tenuepunctatus complex. (d) T. ruficapillus/torquatus complex. Red: northern Atlantic Forest; Green: central-southern Atlantic Forest; Pink: Andean (or central Andean); Brown-Yellow: forests southeast of the Amazon; Pale-Blue: southern Peru-Bolivia region; Gray: Tepuis-Central America; Yellow: Amazonian region. 


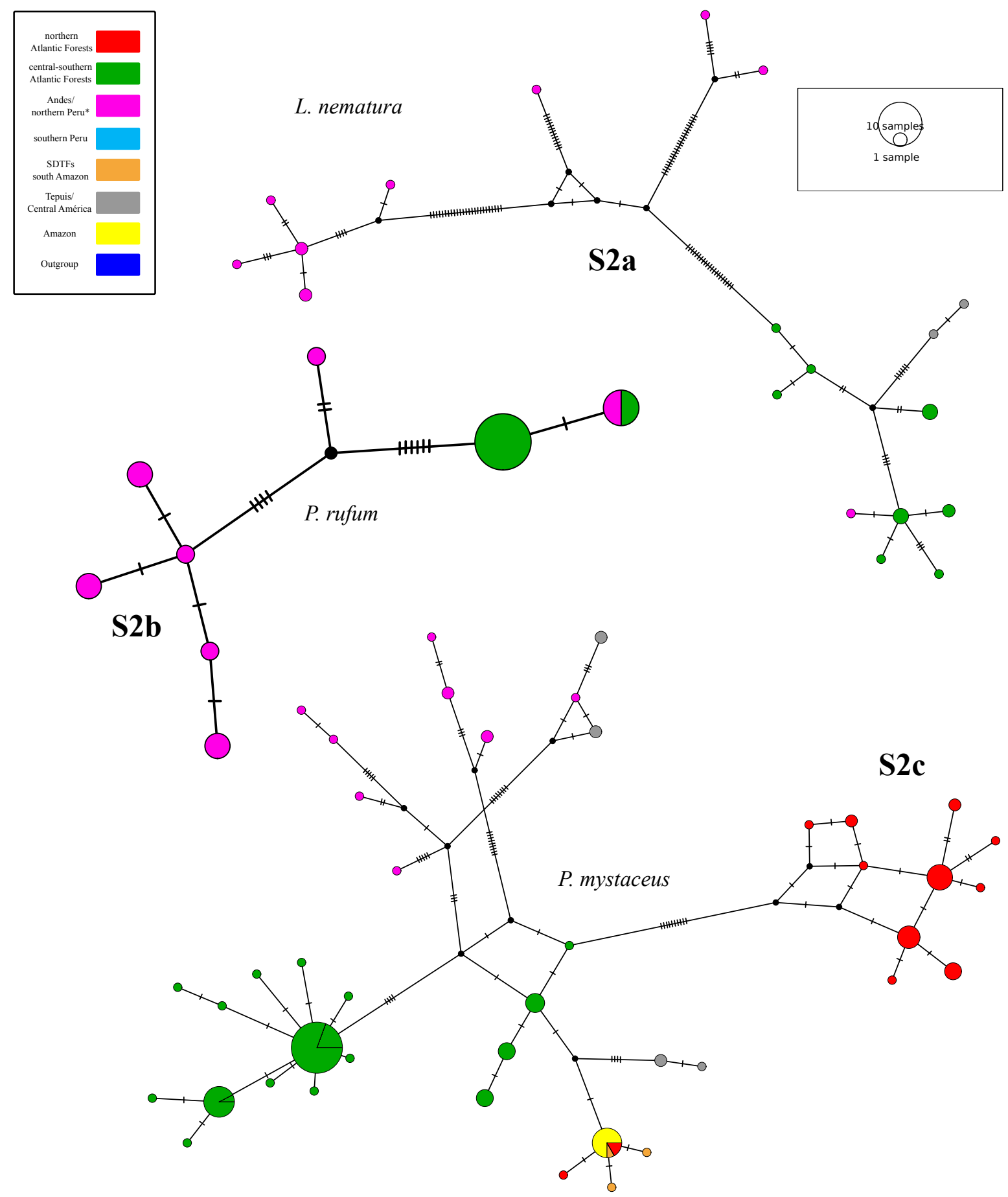

Figure S2. median-joining network depicting relationships among the haplotypes in (a) $L$. nematura. (b) P. rufum. (c) P. mystaceus. Red: northern Atlantic Forest; Green: centralsouthern Atlantic Forest; Pink: Andean (or central Andean); Brown-Yellow: forests southeast of the Amazon; Pale-Blue: southern Peru-Bolivia region; Gray: Tepuis-Central America; Yellow: Amazonian region. 


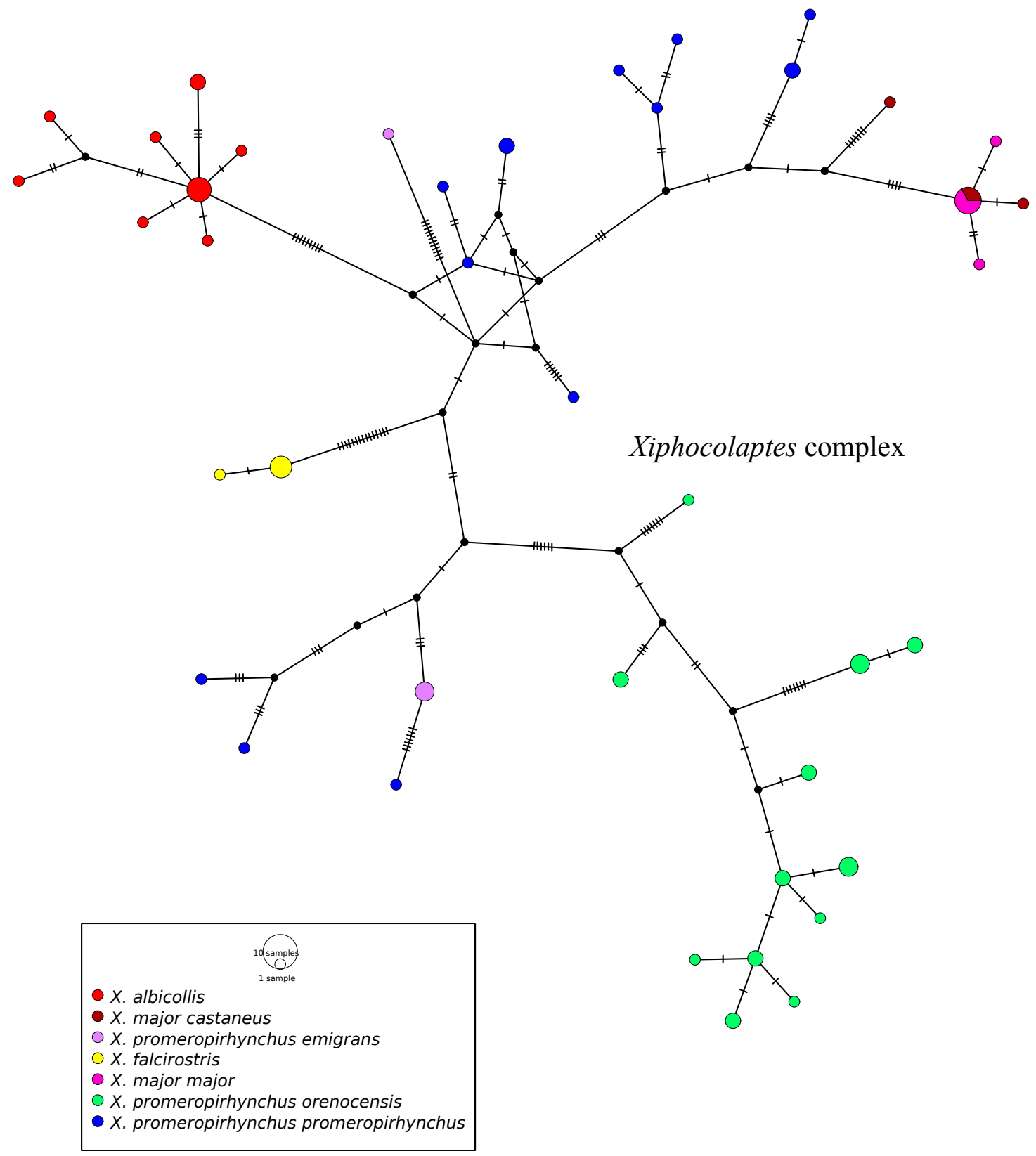

Figure S3. median-joining network depicting relationships among the haplotypes in Xiphocolaptes complex. 


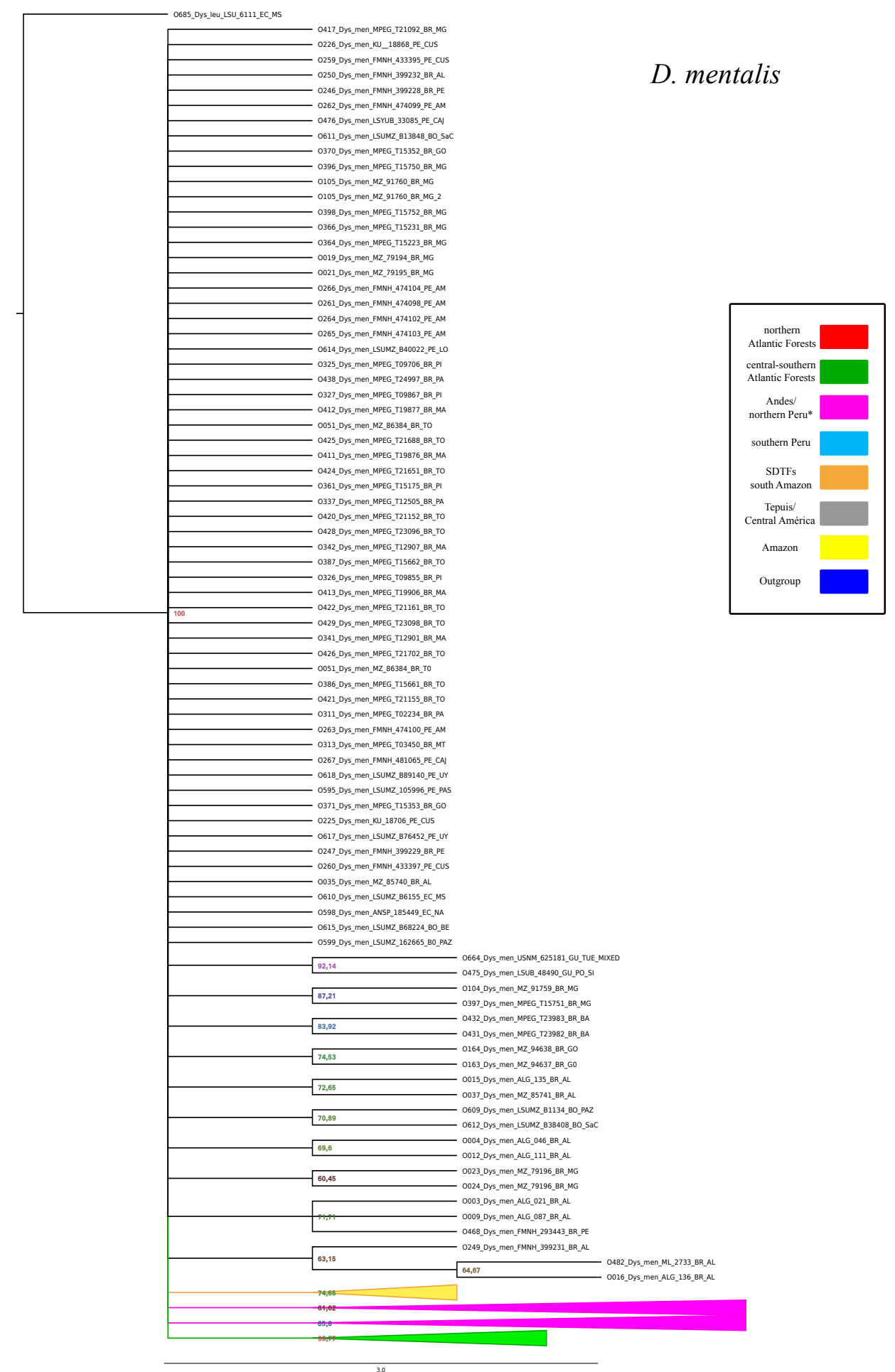

Figure S4. Phylogenetic reconstruction for D. mentalis (Maximum Likelihood). 

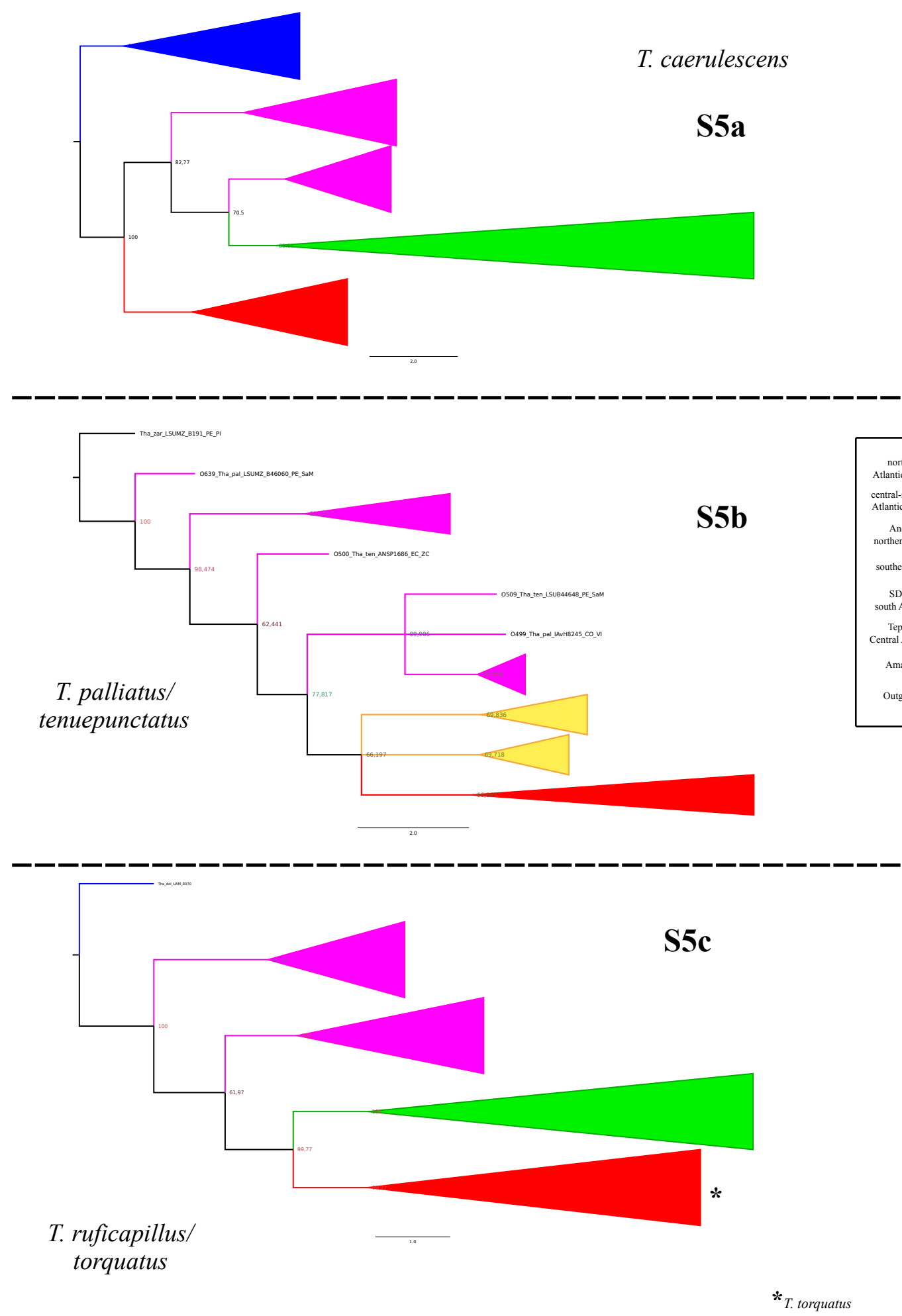

Figure S5. Phylogenetic reconstruction for (a) T. caerulescens. (b) T. palliatus/ tenuepunctatus. (c) T. ruficapillus/torquatus (Maximum Likelihood). 


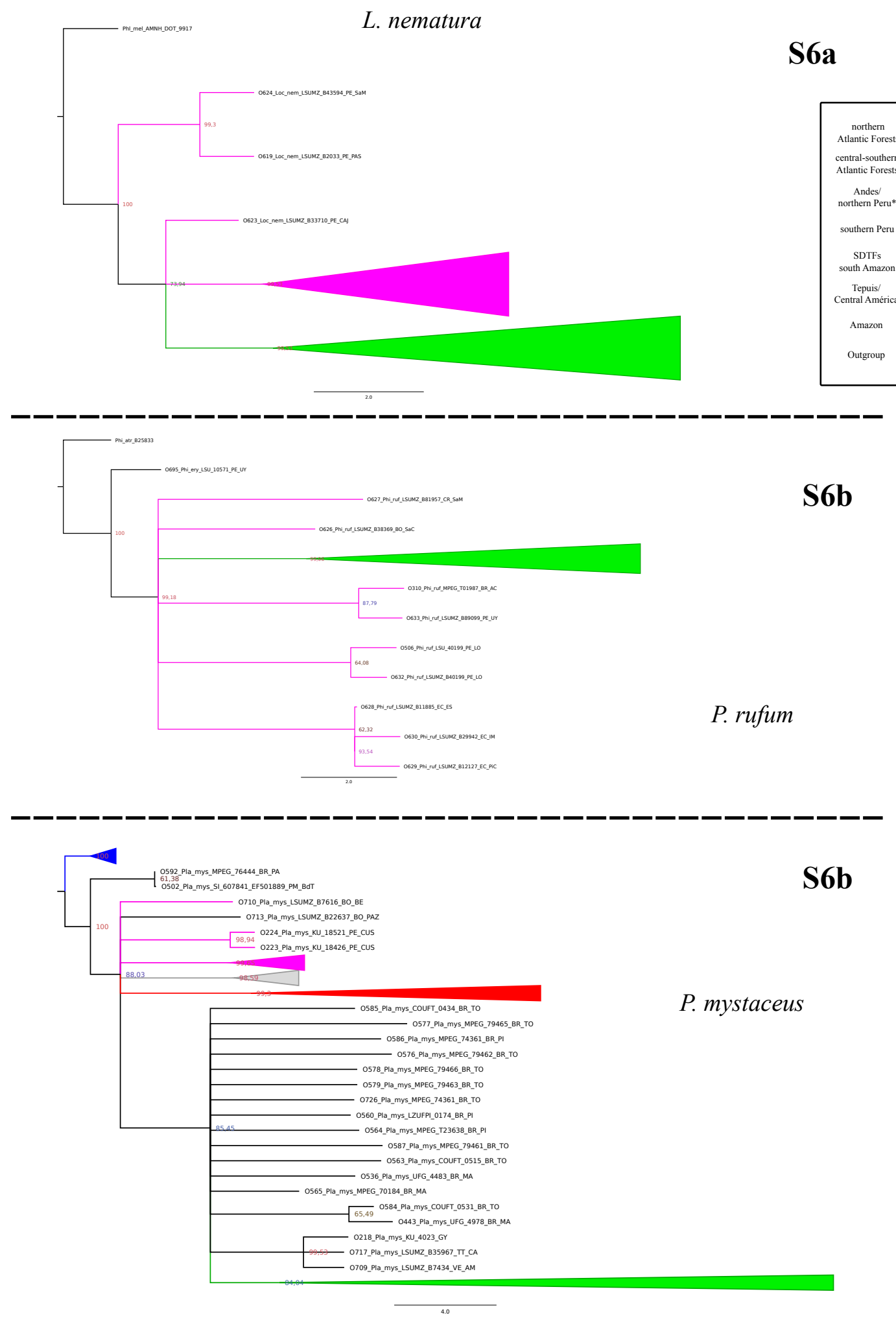

Figure S6. Phylogenetic reconstruction for (a) L. nematura. (b) P. rufum. (c) P. mystaceus (Maximum Likelihood). 


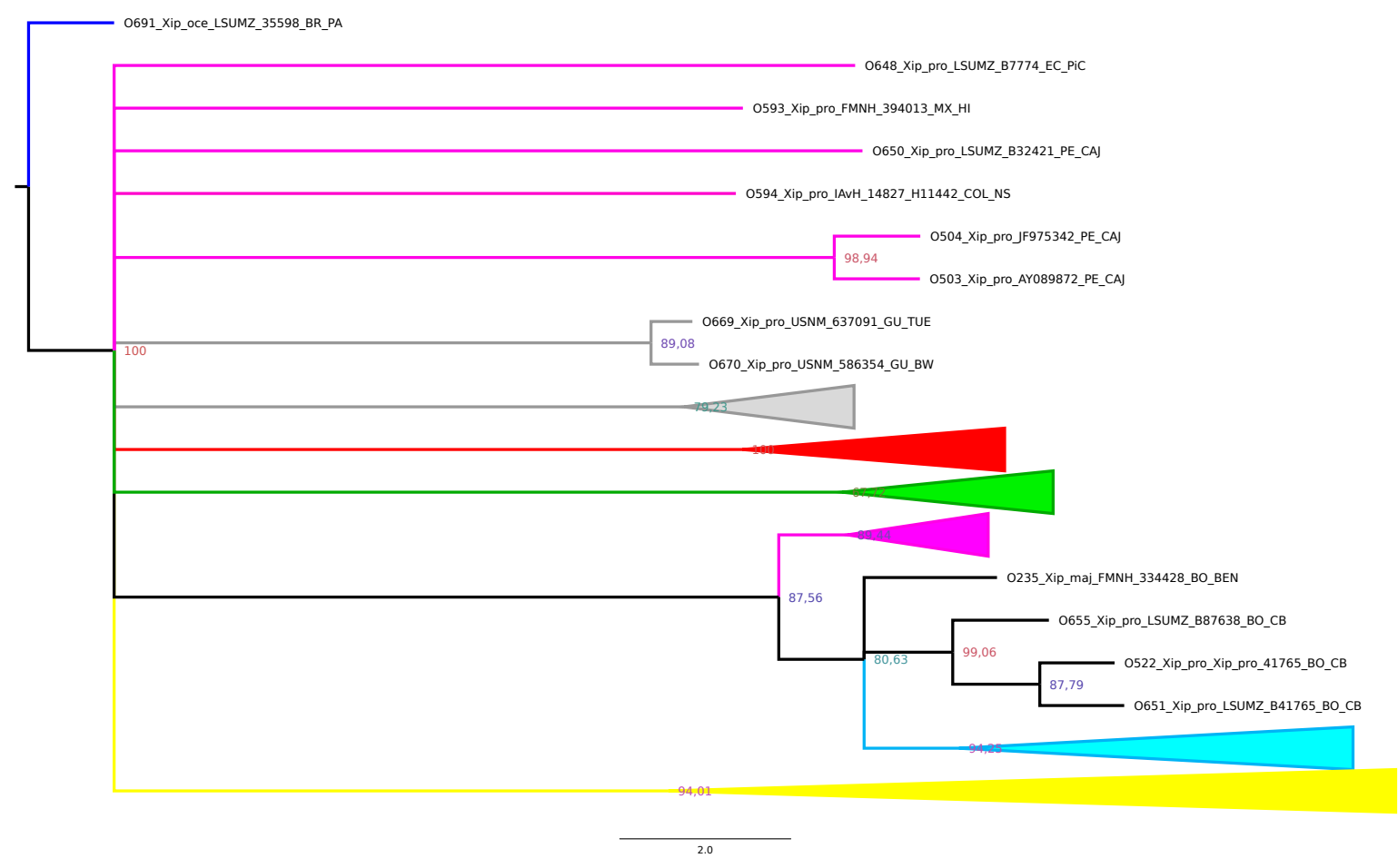

Xiphocolaptes complex

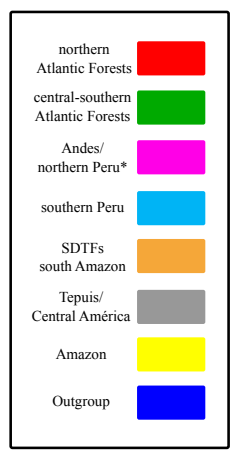

Figure S7. Phylogenetic reconstruction for Xiphocolaptes complex (Maximum Likelihood). 

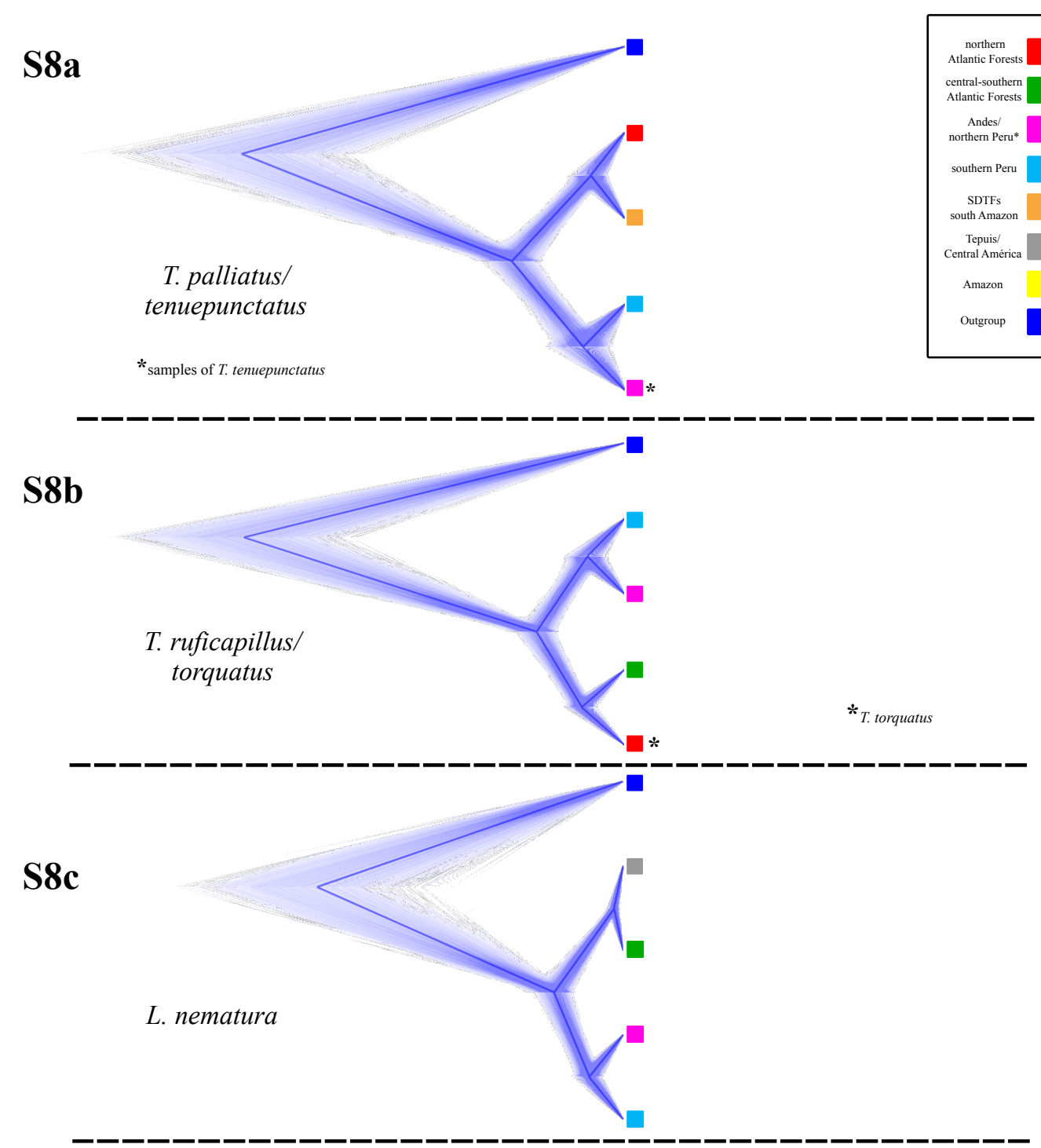

S8d

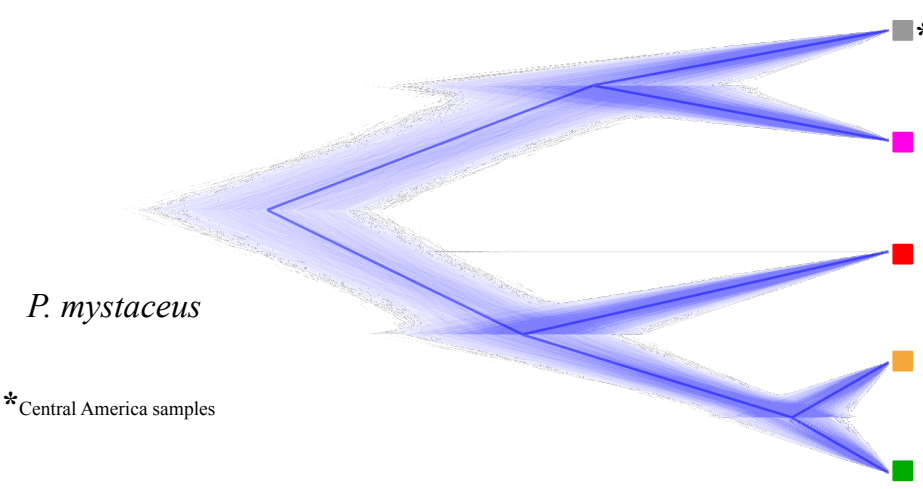

Figure S8. Alternative scenarios tested in SNAPP for (a) T. palliatus/tenuepunctatus. (b) T. ruficapillus/torquatus. (c) L. nematura. (d) P. mystaceus. 


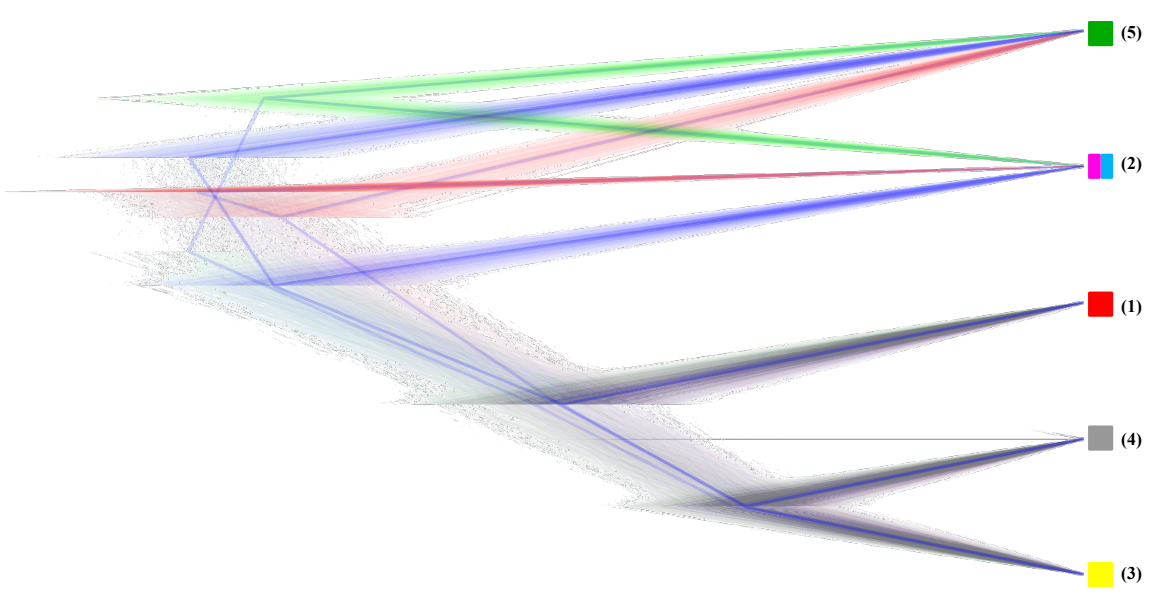

$\begin{array}{cl} & \text { (1) } X . \text { falcirostris } \\ & \text { (2) } X . \text { major }+ \\ \text { Xiphocolaptes } & \text {. promeropirhynchus (promeropirhynchus group) } \\ \text { complex } & \text { (3) X. promeropirhynchus (orenocensis group) } \\ & \text { (4) X. promeropirhynchus (emigrans group) } \\ & \text { (5) } X . \text { albicollis }\end{array}$

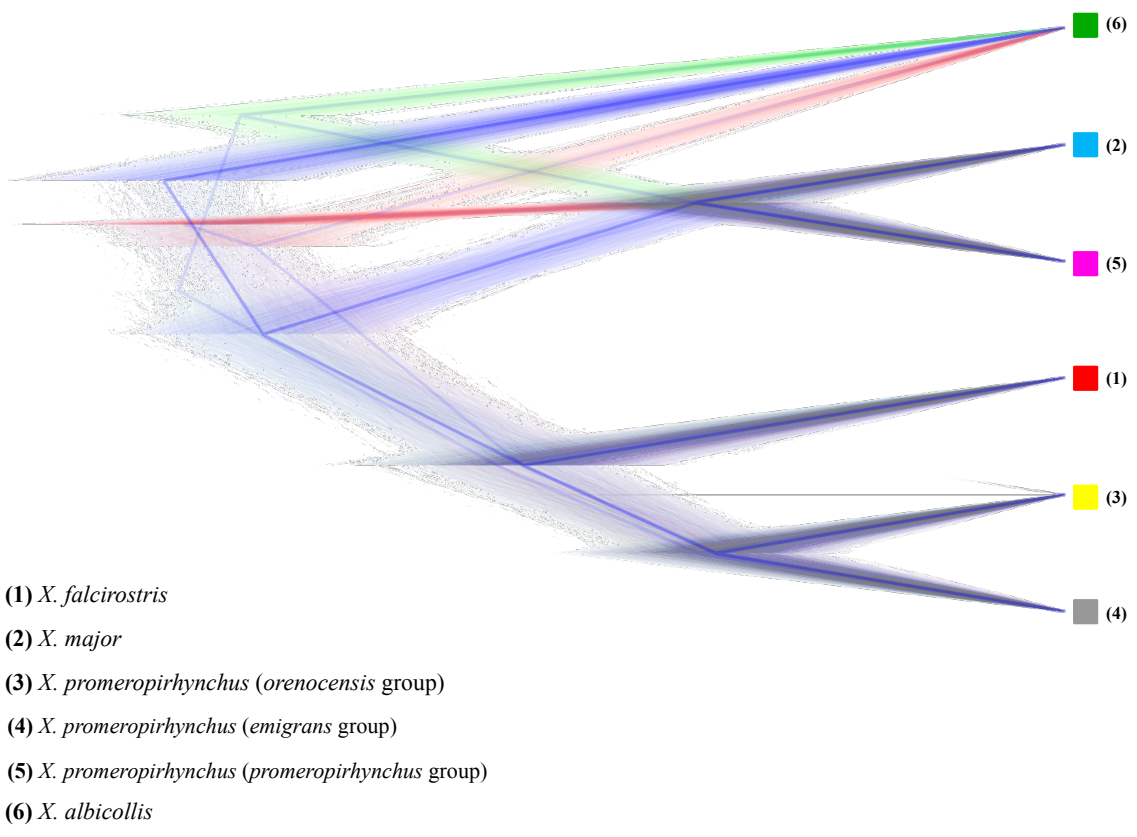

Figure S9. Alternative scenarios tested in SNAPP for Xiphocolaptes complex. 
Chapter II: Comparative phylogeography of passerine birds with a circum-Amazonian distribution (Main Tables).

\section{Table 1.}

\begin{tabular}{|c|c|c|}
\hline Portuguese & Species & Common name (English/Portuguese) \\
\hline Thamnophilidae & Dysithamnus mentalis & Plain Antvireo/Choquinha-lisa \\
\hline Thamnophilidae & Thamnophilus caerulescens & Variable Antshrike/Choca-da-mata \\
\hline Thamnophilidae & Thamnophilus palliatus & Chestnut-backed Antshrike/Choca-listrada \\
\hline Thamnophilidae & Thamnophilus tenuepunctatus & 'Lined Antshrike' (inglês) \\
\hline Thamnophilidae & Thamnophilus ruficapillus & $\begin{array}{c}\text { Southern Rufous-capped Antshrike/Choca-de-chapéu- } \\
\text { vermelho }\end{array}$ \\
\hline Thamnophilidae & Thamnophilus torquatus & Rufous-winged Antshrike/Choca-de-asa-vermelha \\
\hline Furnariidae & Lochmias nematura & Streamcreeper/João-porca \\
\hline Furnariidae & Philydor rufum & Buff-fronted Foliage-gleaner/Limpa-folha-de-testa-baia \\
\hline Platyrinchidae & Platyrinchus mystaceus & White-throated Spadebill/Patinho \\
\hline Dendrocolaptidae & Xiphocolaptes albicollis & White-throated Woodcreeper/Arapaçu-de-garganta- \\
\hline branca
\end{tabular}

Table 2. List of ornithological collections used in this study.

\begin{tabular}{|c|c|}
\hline Museum/Collection & Samples \\
\hline MZUSP & \\
\hline MPEG $^{2}$ & 217 \\
\hline PUC-RS $^{3}$ & 131 \\
\hline KU $^{4}$ & 16 \\
\hline FMNH $^{5}$ & 25 \\
\hline LSU $^{6}$ & 34 \\
\hline NMNH & 50 \\
\hline Fabio Raposo Amaral & 6 \\
\hline Total & $\mathbf{4 8 6}$ \\
\hline
\end{tabular}

Collections: (1) Museu de Zoologia da Universidade de São Paulo, (2) Museu Paraense Emílio Goeldi, (3) Pontifícia Universidade Católica do Rio Grande do Sul, (4) University of Kansas, (5) Field Museum of Natural History, (6) LSU Museum of Natural Science, (7) National Museum of Natural History of the Smithsonian Institute 
Table 3. Best substitution model for the ND2 samples of each species (jModeltest2).

\begin{tabular}{|c|c|c|}
\hline Species & Model AICc & Model BIC \\
\hline Dysithamnus mentalis & TIM3+I+G & TIM3+I+G \\
\hline Lochmias nematura & TVM+G & TPM2uf+G \\
\hline Philydor rufum & TIM2+G & TPM2uf+I \\
\hline Platyrinchus mystaceus & TIM1+I+G & TIM1+G \\
\hline Thamnophilus caerulescens & TrN $+\mathrm{I}+\mathrm{G}$ & $\mathrm{TrN}+\mathrm{G}$ \\
\hline Thamnophilus palliatus/tenuepunctatus complex & $\mathrm{TIM} 1+\mathrm{G}$ & $\mathrm{HKY}+\mathrm{G}$ \\
\hline Thamnophilus ruficapillus/torquatus complex & $\mathrm{TPM} 1 \mathrm{uf}+\mathrm{G}$ & $\mathrm{HKY}+\mathrm{G}$ \\
\hline Xiphocolaptes complex & $\mathrm{TIM} 2+\mathrm{I}$ & $\mathrm{TPM} 2 \mathrm{uf}+\mathrm{I}$ \\
\hline
\end{tabular}

Table 4. Number of loci recovered in the complete and incomplete matrices for each species.

\begin{tabular}{|c|c|c|}
\hline Species & Complete & Incomplete \\
\hline Dysithamnus mentalis & 6 & 1848 \\
\hline Lochmias nematura & 0 & 1950 \\
\hline Philydor rufum & 209 & 1901 \\
\hline Platyrinchus mystaceus & 9 & 1843 \\
\hline Thamnophilus caerulescens & 324 & 2,036 \\
\hline Thamnophilus palliatus/tenuepunctatus complex & 65 & 1855 \\
\hline Thamnophilus ruficapillus/torquatus complex & 74 & 1845 \\
\hline Xiphocolaptes complex & 18 & 1887 \\
\hline
\end{tabular}

* Matrix with few loci, not used for analyses. 
Table 5. Statistics of UCEs after the Illumiprocessor trimming.

\begin{tabular}{|c|c|c|c|}
\hline Species & Mean of reads* & Minimum & Maximum \\
\hline Dysithamnus mentalis & $4,097,390.07$ & 712,910 & $11,636,996$ \\
\hline Lochmias nematura & $3,476,554.27$ & $1,214,882$ & $9,107,376$ \\
\hline Philydor rufum & $4,114,619.60$ & 72,929 & $9,687,756$ \\
\hline Platyrinchus mystaceus & $3,381,776.76$ & $1,463,758$ & $6,144,094$ \\
\hline Thamnophilus caerulescens & $5,702,659.25$ & $1,904,001$ & $10,284,782$ \\
\hline Thamnophilus palliatus/tenuepunctatus complex & $3,884,606.87$ & $1,149,098$ & $8,008,501$ \\
\hline Thamnophilus ruficapillus/torquatus complex & $3,890,676.52$ & $1,380,904$ & $8,066,334$ \\
\hline Xiphocolaptes complex & $3,147,543.00$ & 948,950 & $13,782,612$ \\
\hline
\end{tabular}

*After trimming

Table 6. Statistics of UCEs after the assemble process.

\begin{tabular}{|c|c|c|c|c|c|c|c|}
\hline Species & $\begin{array}{c}\text { Mean of } \\
\text { reads* }\end{array}$ & Minimum & Maximum & $\begin{array}{c}\text { Total } \\
\text { contigs }\end{array}$ & $\begin{array}{c}\text { Mean } \\
\text { length }\end{array}$ & Total bp & $\begin{array}{c}\text { Contigs } \\
>1 K\end{array}$ \\
\hline Dysithamnus mentalis & $13,737.31$ & 4,896 & 157,428 & 810,501 & 500.72 & $337,268,803$ & 18,608 \\
\hline Lochmias nematura & $10,836.91$ & 3,595 & 29,696 & 238,412 & 646.91 & $132,156,469$ & 21,910 \\
\hline Philydor rufum & $9,145.31$ & 1,642 & 25,486 & 539,573 & 516.59 & $262,997,817$ & 18,393 \\
\hline Platyrinchus mystaceus & $13,086.41$ & 2,961 & 29,403 & 222,469 & 535.97 & $107,686,462$ & 15,323 \\
\hline Thamnophilus caerulescens & $17,803.68$ & 4,888 & 143,662 & 498,503 & 464.53 & $185,331,752$ & 4,697 \\
\hline $\begin{array}{c}\text { T. palliatus/tenuepunctatus } \\
\text { complex }\end{array}$ & $13,747.19$ & 5,743 & 75,200 & 426,163 & 521.32 & $191,133,806$ & 14,929 \\
\hline $\begin{array}{c}\text { T. ruficapillus/torquatus } \\
\text { complex }\end{array}$ & $10,998.04$ & 5,517 & 21,193 & 252,955 & 530.60 & $121,822,170$ & 6,347 \\
\hline Xiphocolaptes complex & $10,551.93$ & 2,825 & 32,323 & 453,733 & 566.11 & $235,914,712$ & 30,777 \\
\hline
\end{tabular}

*After Trinity 
Table 7. Values of AIC and $\Delta \mathrm{AIC}$ for D. mentalis (incomplete matrix).

\begin{tabular}{|c|c|c|c|c|c|}
\hline Model & Log_likelihood & n_parameters & AICs & Delta_AIC & weight_AICs \\
\hline Model 1 & -5309.276383 & 8 & 10634.55277 & 81.76809762 & $1.76 \mathrm{E}-18$ \\
\hline Model 2 & -5275.603138 & 12 & 10575.20628 & 22.42160665 & $1.35 \mathrm{E}-05$ \\
\hline Model 3* & $\mathbf{- 5 2 6 2 . 3 9 2 3 3 5}$ & $\mathbf{1 4}$ & $\mathbf{1 0 5 5 2 . 7 8 4 6 7}$ & $\mathbf{0}$ & $\mathbf{1}$ \\
\hline Model 4 & -5261.258098 & 16 & 10554.5162 & 1.731526292 & 0.420730351 \\
\hline Model 5 & -5480.279081 & 18 & 10996.55816 & 443.7734919 & $4.32 \mathrm{E}-97$ \\
\hline Model 6 & -5407.541805 & 18 & 10851.08361 & 298.2989407 & $1.68 \mathrm{E}-65$ \\
\hline Model 7 & -5486.576572 & 18 & 11009.15314 & 456.3684745 & $7.96 \mathrm{E}-100$ \\
\hline Model 8 & -5491.428656 & 22 & 11026.85731 & 474.0726424 & $1.14 \mathrm{E}-103$ \\
\hline Model 9 & -7152.90404 & 22 & 14349.80808 & 3797.023411 & 0 \\
\hline Model 10 & -18294.94633 & 22 & 36633.89266 & 26081.10799 & 0 \\
\hline Model 11 & -5279.918669 & 16 & 10591.83734 & 39.05266805 & $3.31 \mathrm{E}-09$ \\
\hline Model 12 & -5262.817181 & 16 & 10557.63436 & 4.84969321 & 0.088491692 \\
\hline Model 13 & -9709.965268 & 22 & 19463.93054 & 8911.145868 & 0 \\
\hline
\end{tabular}

* Best model for D. mentalis.

Table 8. Values of AIC and $\triangle \mathrm{AIC}$ for T. caerulescens (incomplete matrix).

\begin{tabular}{|c|c|c|c|c|c|}
\hline Model & Log_likelihood & n_parameters & AICs & Delta_AIC & weight_AICs \\
\hline Model 1 & -7481.577811 & 2 & 14967.15562 & 392.1354344 & $7.06 \mathrm{E}-86$ \\
\hline Model 2 & -7383.252541 & 5 & 14776.50508 & 201.4848944 & $1.77 \mathrm{E}-44$ \\
\hline Model 3 & -7386.643388 & 5 & 14783.28678 & 208.2665891 & $5.96 \mathrm{E}-46$ \\
\hline Model 4 & -7323.523233 & 9 & 14665.04647 & 90.02627891 & $2.83 \mathrm{E}-20$ \\
\hline Model 5 & -7345.247239 & 9 & 14708.49448 & 133.4742895 & $1.04 \mathrm{E}-29$ \\
\hline Model 6 & -7299.864124 & 9 & 14617.72825 & 42.70805956 & $5.32 \mathrm{E}-10$ \\
\hline Model 7* & -7274.510094 & $\mathbf{1 3}$ & $\mathbf{1 4 5 7 5 . 0 2 0 1 9}$ & $\mathbf{0}$ & $\mathbf{1}$ \\
\hline Model 8 & -7574.598842 & 11 & 15171.19768 & 596.1774969 & $3.48 \mathrm{E}-130$ \\
\hline Model 9 & -7528.523218 & 11 & 15079.04644 & 504.026249 & $3.57 \mathrm{E}-110$ \\
\hline Model 10 & -7388.482618 & 16 & 14808.96524 & 233.9450474 & $1.58 \mathrm{E}-51$ \\
\hline Model 11 & -7394.500327 & 16 & 14821.00065 & 245.9804667 & $3.85 \mathrm{E}-54$ \\
\hline Model 12 & -7522.21469 & 11 & 15066.42938 & 491.4091924 & $1.96 \mathrm{E}-107$ \\
\hline Model 13 & -7394.482314 & 16 & 14820.96463 & 245.9444395 & $3.93 \mathrm{E}-54$ \\
\hline Model 14 & -7807.853685 & 11 & 15637.70737 & 1062.687182 & $1.74 \mathrm{E}-231$ \\
\hline Model 15 & -7621.885811 & 19 & 15281.77162 & 706.7514342 & $3.40 \mathrm{E}-154$ \\
\hline Model 16 & -7724.954811 & 11 & 15471.90962 & 896.8894352 & $1.75 \mathrm{E}-195$ \\
\hline
\end{tabular}

* Best model for T. caerulescens. 
Table 9. Values of AIC and $\Delta \mathrm{AIC}$ for T. palliatus/tenuepunctatus complex.

\begin{tabular}{|c|c|c|c|c|c|}
\hline Model & Log_likelihood & n_parameters & AICs & Delta_AIC & weight_AICs \\
\hline Model 1 & -6488.079556 & 7 & 12990.15911 & 29.50880915 & $3.91 \mathrm{E}-07$ \\
\hline Model 2 & $\mathbf{- 6 4 6 5 . 3 2 5 1 5 1}$ & $\mathbf{1 5}$ & $\mathbf{1 2 9 6 0 . 6 5 0 3}$ & $\mathbf{0}$ & $\mathbf{1}$ \\
\hline Model 3 & -6468.525541 & 17 & 12971.05108 & 10.4007799 & 0.005514414 \\
\hline Model 4 & -6469.110862 & 18 & 12974.22172 & 13.57142202 & 0.001129804 \\
\hline Model 5 & -6473.793174 & 18 & 12983.58635 & 22.93604613 & $1.05 \mathrm{E}-05$ \\
\hline Model 6 & -6470.946603 & 18 & 12977.89321 & 17.24290411 & 0.000180198 \\
\hline Model 7 & -6477.629595 & 18 & 12991.25919 & 30.60888845 & $2.26 \mathrm{E}-07$ \\
\hline Model 8 & -6477.486628 & 18 & 12990.97326 & 30.3229544 & $2.60 \mathrm{E}-07$ \\
\hline Model 9 & -6470.352923 & 15 & 12970.70585 & 10.05554331 & 0.006553398 \\
\hline Model 10 & -6473.685497 & 17 & 12981.37099 & 20.72069164 & $3.17 \mathrm{E}-05$ \\
\hline Model 11 & -6568.463888 & 18 & 13172.92778 & 212.277474 & $8.03 \mathrm{E}-47$ \\
\hline Model 12 & -6555.799502 & 0 & 13111.599 & 150.9487024 & $1.67 \mathrm{E}-33$ \\
\hline Model 13 & -6602.795104 & 20 & 13245.59021 & 284.9399062 & $1.34 \mathrm{E}-62$ \\
\hline Model 14 & -6626.392417 & 20 & 13292.78483 & 332.1345312 & $7.55 \mathrm{E}-73$ \\
\hline Model 15 & -6563.466586 & 28 & 13182.93317 & 222.282869 & $5.39 \mathrm{E}-49$ \\
\hline Model 16 & -7937.080681 & 23 & 15920.16136 & 2959.511059 & 0 \\
\hline Model 17 & -7814.284258 & 21 & 15670.56852 & 2709.918214 & 0 \\
\hline Model 18 & -6469.870035 & 20 & 12979.74007 & 19.0897677 & $7.16 \mathrm{E}-05$ \\
\hline Model 19 & -6605.452577 & 21 & 13252.90515 & 292.2548514 & $3.45 \mathrm{E}-64$ \\
\hline
\end{tabular}

* Best model for T. palliatus/tenuepunctatus complex.

Table 10. Values of AIC and $\triangle \mathrm{AIC}$ for T. ruficapillus/torquatus complex.

\begin{tabular}{|c|c|c|c|c|c|}
\hline Model & Log_likelihood & n_parameters & AICs & Delta_AIC & weight_AICs \\
\hline Model 1 & -6774.176937 & 7 & 13562.35387 & 173.1198488 & $2.56 \mathrm{E}-38$ \\
\hline Model 2* & $\mathbf{- 6 6 7 5 . 6 1 7 0 1 3}$ & $\mathbf{1 9}$ & $\mathbf{1 3 3 8 9 . 2 3 4 0 3}$ & $\mathbf{0}$ & $\mathbf{1}$ \\
\hline Model 3 & -6676.236177 & 19 & 13390.47235 & 1.238327941 & 0.538394363 \\
\hline Model 4 & -6693.848291 & 19 & 13425.69658 & 36.46255731 & $1.21 \mathrm{E}-08$ \\
\hline Model 5 & -6687.52161 & 19 & 13413.04322 & 23.80919384 & $6.76 \mathrm{E}-06$ \\
\hline Model 6 & -7569.224441 & 23 & 15184.44888 & 1795.214857 & 0 \\
\hline Model 7* & -7582.263814 & 23 & 15210.52763 & 1821.293602 & 0 \\
\hline Model 8 & -7683.624616 & 23 & 15413.24923 & 2024.015207 & 0 \\
\hline
\end{tabular}

* Best model for T. ruficapillus/torquatus complex. 
Chapter II: Comparative phylogeography of passerine birds with a circum-Amazonian distribution (Supplementary material).

Table S1. List summarized of all samples gathered for this study.

\begin{tabular}{|c|c|c|c|c|c|}
\hline $\begin{array}{l}\text { Internal } \\
\text { number }\end{array}$ & $\begin{array}{c}\text { number/field } \\
\text { number }\end{array}$ & Taxon & State & $\begin{array}{c}\text { UCEs } \\
\text { Sequences }\end{array}$ & $\begin{array}{c}\text { ND2 } \\
\text { Sequences }\end{array}$ \\
\hline 0001 & ALG-014 & Thamnophilus caerulescens & Alagoas & & YES \\
\hline 0002 & ALG-020 & Thamnophilus caerulescens & Alagoas & YES & YES \\
\hline 0003 & ALG-021 & Dysithamnus mentalis & Alagoas & & YES \\
\hline 0004 & ALG-046 & Dysithamnus mentalis & Alagoas & YES & YES \\
\hline 0005 & ALG-053 & Thamnophilus caerulescens & Alagoas & & \\
\hline 0006 & ALG-080 & Thamnophilus caerulescens & Alagoas & YES & YES \\
\hline 0007 & ALG-085 & Thamnophilus caerulescens & Alagoas & YES & YES \\
\hline 0008 & ALG-086 & Thamnophilus caerulescens & Alagoas & YES & YES \\
\hline 0009 & ALG-087 & Dysithamnus mentalis & Alagoas & YES & YES \\
\hline 0010 & ALG-102 & Thamnophilus caerulescens & Alagoas & YES & YES \\
\hline 0011 & ALG-110 & Dysithamnus mentalis & Alagoas & & \\
\hline 0012 & ALG-111 & Dysithamnus mentalis & Alagoas & & YES \\
\hline 0013 & ALG-116 & Platyrinchus mystaceus & Alagoas & & YES \\
\hline 0014 & ALG-117 & Platyrinchus mystaceus & Alagoas & & YES \\
\hline 0015 & ALG-135 & Dysithamnus mentalis & Alagoas & & YES \\
\hline 0016 & ALG-136 & Dysithamnus mentalis & Alagoas & & YES \\
\hline 0017 & J_2216 & $\begin{array}{c}\text { Thamnophilus palliatus } \\
\text { puncticeps }\end{array}$ & Rondônia & YES & YES \\
\hline 0018 & J_2217 & $\begin{array}{c}\text { Thamnophilus palliatus } \\
\text { puncticeps }\end{array}$ & Rondônia & YES & YES \\
\hline 0019 & MZ_79194 & Dysithamnus mentalis & Minas Gerais & YES & YES \\
\hline 0021 & MZ_79195 & Dysithamnus mentalis & Minas Gerais & YES & YES \\
\hline 0023 & MZ_79196 & Dysithamnus mentalis & Minas Gerais & YES & YES \\
\hline 0026 & MZ_79203 & Dysithamnus mentalis & Minas Gerais & & YES \\
\hline 0027 & MZ_81479 & Dysithamnus mentalis & São Paulo & & YES \\
\hline 0028 & MZ_81480 & Dysithamnus mentalis & São Paulo & & YES \\
\hline 0030 & MZ_82619 & $\begin{array}{c}\text { Thamnophilus caerulescens } \\
\text { caerulescens }\end{array}$ & São Paulo & & YES \\
\hline 0032 & MZ_82637 & $\begin{array}{c}\text { Thamnophilus caerulescens } \\
\text { caerulescens }\end{array}$ & Minas Gerais & YES & YES \\
\hline 0033 & MZ_85427 & Thamnophilus ruficapillus & Minas Gerais & YES & YES \\
\hline 0034 & MZ_85660 & Platyrinchus mystaceus & São Paulo & & YES \\
\hline 0035 & MZ_85740 & Dysithamnus mentalis & Alagoas & YES & YES \\
\hline
\end{tabular}




\begin{tabular}{|c|c|c|c|c|c|}
\hline $\begin{array}{l}\text { Internal } \\
\text { number }\end{array}$ & $\begin{array}{c}\text { number/field } \\
\text { number }\end{array}$ & Taxon & State & $\begin{array}{c}\text { UCEs } \\
\text { Sequences }\end{array}$ & $\begin{array}{c}\text { ND2 } \\
\text { Sequences }\end{array}$ \\
\hline 0037 & MZ_85741 & Dysithamnus mentalis & Alagoas & YES & YES \\
\hline 0038 & MZ_85745 & Platyrinchus mystaceus & Alagoas & YES & YES \\
\hline 0039 & MZ_85759 & Platyrinchus mystaceus & Alagoas & & \\
\hline 0040 & MZ_85760 & Platyrinchus mystaceus & Alagoas & YES & YES \\
\hline 0042 & MZ_85805 & Platyrinchus mystaceus & Pernambuco & YES & YES \\
\hline 0043 & MZ_85806 & Platyrinchus mystaceus & Pernambuco & & YES \\
\hline 0044 & MZ_85832 & Platyrinchus mystaceus & Alagoas & & YES \\
\hline 0046 & MZ_85833 & Platyrinchus mystaceus & Alagoas & YES & YES \\
\hline 0047 & MZ_86001 & Thamnophilus palliatus & Minas Gerais & YES & YES \\
\hline 0049 & MZ_86016 & Thamnophilus palliatus & Bahia & YES & YES \\
\hline 0051 & MZ_86384 & Dysithamnus mentalis & Tocantins & YES & YES \\
\hline 0052 & MZ_87826 & Platyrinchus mystaceus & São Paulo & & YES \\
\hline 0053 & MZ_87827 & Platyrinchus mystaceus & São Paulo & & YES \\
\hline 0054 & MZ_87828 & Platyrinchus mystaceus & São Paulo & & YES \\
\hline 0055 & MZ_87829 & Platyrinchus mystaceus & São Paulo & & YES \\
\hline 0056 & MZ_87833 & Dysithamnus mentalis & São Paulo & & YES \\
\hline 0057 & MZ_87834 & Dysithamnus mentalis & São Paulo & YES & YES \\
\hline 0058 & MZ_88334 & Platyrinchus mystaceus & Rio de Janeiro & YES & YES \\
\hline 0059 & MZ_88399 & Dysithamnus mentalis & São Paulo & & YES \\
\hline 0066 & MZ_90916 & Thamnophilus palliatus & Bahia & YES & YES \\
\hline 0067 & MZ_90917 & Thamnophilus palliatus & Bahia & YES & YES \\
\hline 0068 & MZ_90946 & Xiphocolaptes albicollis & Bahia & & YES \\
\hline 0069 & MZ_90947 & Xiphocolaptes albicollis & Bahia & YES & YES \\
\hline 0070 & MZ_90971 & Platyrinchus mystaceus & Bahia & & YES \\
\hline 0071 & MZ_90972 & Platyrinchus mystaceus & Bahia & & YES \\
\hline 0072 & MZ_90973 & Platyrinchus mystaceus & Bahia & & YES \\
\hline 0073 & MZ_90974 & Platyrinchus mystaceus & Bahia & YES & YES \\
\hline 0074 & MZ_90975 & Platyrinchus mystaceus & Bahia & YES & YES \\
\hline 0075 & MZ_90976 & Platyrinchus mystaceus & Bahia & & YES \\
\hline 0076 & MZ_90977 & Platyrinchus mystaceus & Bahia & & YES \\
\hline 0077 & MZ_90978 & Platyrinchus mystaceus & Bahia & YES & YES \\
\hline 0078 & MZ_91196 & $\begin{array}{c}\text { Thamnophilus caerulescens } \\
\text { gilvigaster }\end{array}$ & Santa Catarina & YES & YES \\
\hline 0079 & MZ_91197 & $\begin{array}{c}\text { Thamnophilus caerulescens } \\
\text { gilvigaster }\end{array}$ & Santa Catarina & YES & \\
\hline 0080 & MZ_91201 & Dysithamnus mentalis & Santa Catarina & YES & YES \\
\hline 0084 & MZ_91246 & Lochmias nematura & Santa Catarina & YES & YES \\
\hline 0085 & MZ_91254 & Philydor rufum & Santa Catarina & YES & YES \\
\hline 0086 & MZ_91267 & Platyrinchus mystaceus & Santa Catarina & & YES \\
\hline
\end{tabular}




\begin{tabular}{|c|c|c|c|c|c|}
\hline $\begin{array}{l}\text { Internal } \\
\text { number }\end{array}$ & $\begin{array}{c}\text { number/field } \\
\text { number }\end{array}$ & Taxon & State & $\begin{array}{c}\text { UCEs } \\
\text { Sequences }\end{array}$ & $\begin{array}{c}\text { ND2 } \\
\text { Sequences } \\
\end{array}$ \\
\hline 0087 & MZ_91268 & Platyrinchus mystaceus & Santa Catarina & YES & YES \\
\hline 0088 & MZ_91269 & Platyrinchus mystaceus & Santa Catarina & YES & YES \\
\hline 0089 & MZ_91380 & Thamnophilus palliatus & Bahia & & YES \\
\hline 0090 & MZ_91465 & Platyrinchus mystaceus & Bahia & YES & YES \\
\hline 0091 & MZ_91466 & Platyrinchus mystaceus & Bahia & YES & YES \\
\hline 0092 & MZ_91467 & Platyrinchus mystaceus & Bahia & & YES \\
\hline 0097 & MZ_91661 & $\begin{array}{c}\text { Thamnophilus caerulescens } \\
\text { caerulescens }\end{array}$ & São Paulo & YES & YES \\
\hline 0098 & MZ_91681 & Platyrinchus mystaceus & São Paulo & YES & YES \\
\hline 0099 & MZ_91682 & Platyrinchus mystaceus & São Paulo & & YES \\
\hline 0100 & MZ_91683 & Platyrinchus mystaceus & São Paulo & & YES \\
\hline 0101 & MZ_91684 & Platyrinchus mystaceus & São Paulo & & YES \\
\hline 0102 & MZ_91685 & Platyrinchus mystaceus & São Paulo & & YES \\
\hline 0103 & MZ_91755 & $\begin{array}{c}\text { Thamnophilus caerulescens } \\
\text { caerulescens }\end{array}$ & Minas Gerais & & YES \\
\hline 0104 & MZ_91759 & Dysithamnus mentalis & Minas Gerais & YES & YES \\
\hline 0105 & MZ_91760 & Dysithamnus mentalis & Minas Gerais & YES & YES \\
\hline 0107 & MZ_92136 & Xiphocolaptes albicollis & São Paulo & & YES \\
\hline 0108 & MZ_92160 & Dysithamnus mentalis & São Paulo & & YES \\
\hline 0109 & MZ_92161 & Dysithamnus mentalis & São Paulo & & YES \\
\hline 0110 & MZ_92162 & Dysithamnus mentalis & São Paulo & & YES \\
\hline 0111 & MZ_92163 & Dysithamnus mentalis & São Paulo & & YES \\
\hline 0112 & MZ_92164 & Dysithamnus mentalis & São Paulo & & YES \\
\hline 0113 & MZ_92165 & Dysithamnus mentalis & São Paulo & & YES \\
\hline 0116 & MZ_92168 & Platyrinchus mystaceus & São Paulo & & YES \\
\hline 0117 & MZ_92169 & Platyrinchus mystaceus & São Paulo & & YES \\
\hline 0118 & MZ_92170 & Platyrinchus mystaceus & São Paulo & & YES \\
\hline 0119 & MZ_92171 & Platyrinchus mystaceus & São Paulo & & YES \\
\hline 0120 & MZ_92172 & Platyrinchus mystaceus & São Paulo & & YES \\
\hline 0121 & MZ_92173 & Platyrinchus mystaceus & São Paulo & & YES \\
\hline 0123 & MZ_92478 & Lochmias nematura & São Paulo & YES & YES \\
\hline 0127 & MZ_92487 & Platyrinchus mystaceus & São Paulo & YES & YES \\
\hline 0128 & MZ_92488 & Platyrinchus mystaceus & São Paulo & & YES \\
\hline 0129 & MZ_92489 & Platyrinchus mystaceus & São Paulo & & YES \\
\hline 0130 & MZ_92490 & Platyrinchus mystaceus & São Paulo & & \\
\hline 0131 & MZ_93101 & Dysithamnus mentalis & São Paulo & & YES \\
\hline 0133 & MZ_93175 & Dysithamnus mentalis & São Paulo & YES & YES \\
\hline 0134 & MZ_93176 & $\begin{array}{c}\text { Thamnophilus caerulescens } \\
\text { caerulescens }\end{array}$ & São Paulo & YES & YES \\
\hline 0135 & MZ_93203 & Xiphocolaptes albicollis & São Paulo & YES & YES \\
\hline
\end{tabular}




\begin{tabular}{|c|c|c|c|c|c|}
\hline $\begin{array}{l}\text { Internal } \\
\text { number }\end{array}$ & $\begin{array}{c}\text { number/field } \\
\text { number }\end{array}$ & Taxon & State & $\begin{array}{c}\text { UCEs } \\
\text { Sequences }\end{array}$ & $\begin{array}{c}\text { ND2 } \\
\text { Sequences }\end{array}$ \\
\hline 0136 & MZ_93204 & Xiphocolaptes albicollis & São Paulo & YES & YES \\
\hline 0137 & MZ_93208 & Lochmias nematura & São Paulo & & YES \\
\hline 0138 & MZ_93226 & Platyrinchus mystaceus & São Paulo & & YES \\
\hline 0139 & MZ_93227 & Platyrinchus mystaceus & São Paulo & & YES \\
\hline 0140 & MZ_93228 & Platyrinchus mystaceus & São Paulo & & YES \\
\hline 0141 & MZ_93229 & Platyrinchus mystaceus & São Paulo & & YES \\
\hline 0142 & MZ_93230 & Platyrinchus mystaceus & São Paulo & & YES \\
\hline 0143 & MZ_93231 & Platyrinchus mystaceus & São Paulo & & YES \\
\hline 0144 & MZ_93232 & Platyrinchus mystaceus & São Paulo & & YES \\
\hline 0145 & MZ_93233 & Platyrinchus mystaceus & São Paulo & & YES \\
\hline 0146 & MZ_93234 & Platyrinchus mystaceus & São Paulo & YES & YES \\
\hline 0147 & MZ_93408 & Thamnophilus palliatus & Pará & YES & YES \\
\hline 0148 & MZ_93501 & Dysithamnus mentalis & São Paulo & & YES \\
\hline 0149 & MZ_93502 & Dysithamnus mentalis & São Paulo & & YES \\
\hline 0150 & MZ_93511 & Xiphocolaptes albicollis & São Paulo & YES & YES \\
\hline 0151 & MZ_93512 & Xiphocolaptes albicollis & São Paulo & & YES \\
\hline 0152 & MZ_93513 & Xiphocolaptes albicollis & São Paulo & & YES \\
\hline 0153 & MZ_93514 & Philydor rufum & São Paulo & YES & YES \\
\hline 0161 & MZ_94441 & Platyrinchus mystaceus & Minas Gerais & & YES \\
\hline 0163 & MZ_94637 & Dysithamnus mentalis & Goiás & YES & YES \\
\hline 0164 & MZ_94638 & Dysithamnus mentalis & Goiás & YES & YES \\
\hline 0165 & MZ_95594 & Thamnophilus palliatus & Pará & & YES \\
\hline 0166 & MZ_96752 & $\begin{array}{c}\text { Thamnophilus caerulescens } \\
\text { caerulescens }\end{array}$ & São Paulo & & YES \\
\hline 0167 & MZ_96753 & $\begin{array}{c}\text { Thamnophilus caerulescens } \\
\text { caerulescens }\end{array}$ & São Paulo & & \\
\hline 0168 & MZ_96754 & $\begin{array}{c}\text { Thamnophilus caerulescens } \\
\text { caerulescens }\end{array}$ & São Paulo & & YES \\
\hline 0169 & MZ_96755 & $\begin{array}{c}\text { Thamnophilus caerulescens } \\
\text { caerulescens }\end{array}$ & São Paulo & & YES \\
\hline 0170 & MZ_96769 & Xiphocolaptes albicollis & São Paulo & YES & YES \\
\hline 0176 & MZ_98298 & Platyrinchus mystaceus & Minas Gerais & & YES \\
\hline 0177 & MZ_98297 & Dysithamnus mentalis & Minas Gerais & & YES \\
\hline 0183 & MZ_92715 & $\begin{array}{c}\text { Xiphocolaptes } \\
\text { promeropirhynchus paraensis }\end{array}$ & Mato Grosso & & YES \\
\hline 0184 & MZ_94552 & $\begin{array}{c}\text { Xiphocolaptes } \\
\text { promeropirhynchus paraensis }\end{array}$ & Pará & & YES \\
\hline 0185 & ML 1529 & Platyrinchus mystaceus & São Paulo & & YES \\
\hline 0186 & SM 19 & Dysithamnus mentalis & São Paulo & & YES \\
\hline 0188 & FRA_168 & Dysithamnus mentalis & Paraná & & YES \\
\hline 0189 & FRA_178 & Lochmias nematura & Paraná & & YES \\
\hline 0190 & FRA_230 & Philydor rufum & Paraná & & YES \\
\hline
\end{tabular}




\begin{tabular}{|c|c|c|c|c|c|}
\hline $\begin{array}{l}\text { Internal } \\
\text { number }\end{array}$ & $\begin{array}{c}\text { number/field } \\
\text { number }\end{array}$ & Taxon & State & $\begin{array}{c}\text { UCEs } \\
\text { Sequences }\end{array}$ & $\begin{array}{c}\text { ND2 } \\
\text { Sequences } \\
\end{array}$ \\
\hline 0191 & FRA_233 & Philydor rufum & Paraná & & YES \\
\hline 0192 & BOR-14-27 & Dysithamnus mentalis & São Paulo & & YES \\
\hline 0193 & BOR-14-75 & Dysithamnus mentalis & São Paulo & & YES \\
\hline 0194 & BOR-14-76 & Dysithamnus mentalis & São Paulo & & YES \\
\hline 0195 & BOR-14-94 & Platyrinchus mystaceus & São Paulo & & YES \\
\hline 0196 & BOR-14-95 & Platyrinchus mystaceus & São Paulo & & YES \\
\hline 0198 & FRA_258 & Thamnophilus caerulescens & São Paulo & & YES \\
\hline 0199 & PQP_16 & Philydor rufum & Paraná & YES & YES \\
\hline 0200 & PQP_21 & Dysithamnus mentalis & São Paulo & YES & YES \\
\hline 0202 & OBR-026 & Platyrinchus mystaceus & Mato Grosso do Sul & YES & YES \\
\hline 0206 & $\mathrm{KU}_{-} 40$ & Platyrinchus mystaceus & Concepcion & YES & YES \\
\hline 0207 & KU_57 & Platyrinchus mystaceus & Concepcion & YES & YES \\
\hline 0208 & $\mathrm{KU}_{-} 160$ & Xiphocolaptes major & Concepcion & YES & YES \\
\hline 0209 & KU_273 & Dysithamnus mentalis & Caazapa & YES & YES \\
\hline 0210 & KU_274 & Dysithamnus mentalis & Caazapa & YES & YES \\
\hline 0211 & $\mathrm{KU}_{-} 405$ & Philydor rufus & Concepcion & YES & YES \\
\hline 0212 & $\mathrm{KU}_{-} 406$ & Philydor rufus & Concepcion & & YES \\
\hline 0213 & KU_ 3187 & Xiphocolaptes major & Alto Paraguay & & YES \\
\hline 0214 & KU_ 3195 & Thamnophilus caerulescens & Alto Paraguay & YES & YES \\
\hline 0215 & KU_3215 & Xiphocolaptes major & Alto Paraguay & & YES \\
\hline 0216 & $\mathrm{KU}_{-} 3700$ & Thamnophilus caerulescens & Itapua & YES & YES \\
\hline 0217 & KU_ 3721 & Thamnophilus caerulescens & Caazapa/Itapua & YES & YES \\
\hline 0218 & KU_4023 & Platyrinchus mystaceus duidae & Guyana & YES & YES \\
\hline 0219 & KU_ 9040 & $\begin{array}{c}\text { Xiphocolaptes } \\
\text { promeropirhynchus } \\
\end{array}$ & $\begin{array}{l}\text { El Salvador, } \\
\text { Chalatenango }\end{array}$ & YES & YES \\
\hline 0220 & KU_ 9772 & Xiphocolaptes major & Jujuy & YES & YES \\
\hline 0221 & KU_ 9864 & $\begin{array}{c}\text { Thamnophilus ruficapillus } \\
\text { cochabambae }\end{array}$ & Jujuy & YES & YES \\
\hline 0222 & $\mathrm{KU}_{-} 17412$ & Thamnophilus palliatus & Junin & YES & YES \\
\hline 0223 & $\mathrm{KU}_{-} 18426$ & Platyrinchus mystaceus & Cusco & YES & YES \\
\hline 0224 & $\mathrm{KU}_{-} 18521$ & Platyrinchus mystaceus & Cusco & YES & YES \\
\hline 0225 & KU_ 18706 & Dysithamnus mentalis & Cusco & YES & YES \\
\hline 0226 & KU_ 18868 & Dysithamnus mentalis & Cusco & & YES \\
\hline 0227 & KU_21588 & Thamnophilus ruficapillus & Puno & YES & YES \\
\hline 0228 & KU_ 21589 & Thamnophilus ruficapillus & Puno & YES & YES \\
\hline 0229 & KU_2 21634 & Thamnophilus caerulescens & Puno & & YES \\
\hline 0230 & KU_21654 & Thamnophilus caerulescens & Puno & YES & YES \\
\hline 0234 & FMNH_334427 & Xiphocolaptes major castaneus & Santa Cruz & YES & YES \\
\hline 0235 & FMNH_334428 & Xiphocolaptes major castaneus & El Beni & YES & YES \\
\hline
\end{tabular}




\begin{tabular}{|c|c|c|c|c|c|}
\hline $\begin{array}{l}\text { Internal } \\
\text { number }\end{array}$ & $\begin{array}{c}\text { number/field } \\
\text { number }\end{array}$ & Taxon & State & $\begin{array}{c}\text { UCEs } \\
\text { Sequences }\end{array}$ & $\begin{array}{c}\text { ND2 } \\
\text { Sequences } \\
\end{array}$ \\
\hline 0243 & FMNH_397978 & Lochmias nematura obscurata & Cusco & YES & YES \\
\hline 0244 & FMNH_397980 & Lochmias nematura obscurata & Cusco & & YES \\
\hline 0245 & FMNH_397982 & Lochmias nematura obscurata & Cusco & & YES \\
\hline 0246 & FMNH_399228 & Dysithamnus mentalis emiliae & Pernambuco & & YES \\
\hline 0247 & FMNH_399229 & Dysithamnus mentalis emiliae & Pernambuco & & YES \\
\hline 0248 & FMNH_399230 & Dysithamnus mentalis emiliae & Alagoas & & YES \\
\hline 0249 & FMNH_399231 & Dysithamnus mentalis emiliae & Alagoas & YES & YES \\
\hline 0250 & FMNH_399232 & Dysithamnus mentalis emiliae & Alagoas & & YES \\
\hline 0254 & FMNH_429981 & Lochmias nematura obscurata & Cusco & YES & YES \\
\hline 0255 & FMNH_429983 & Lochmias nematura obscurata & Cusco & YES & YES \\
\hline 0256 & FMNH_429984 & $\begin{array}{c}\text { Thamnophilus palliatus } \\
\text { puncticeps }\end{array}$ & Cusco & YES & YES \\
\hline 0257 & FMNH_433368 & Lochmias nematura obscurata & Cusco & YES & YES \\
\hline 0258 & FMNH_433393 & Dysithamnus mentalis tavarae & Cusco & & YES \\
\hline 0259 & FMNH_433395 & Dysithamnus mentalis tavarae & Cusco & YES & YES \\
\hline 0260 & FMNH_433397 & Dysithamnus mentalis tavarae & Cusco & YES & YES \\
\hline 0261 & FMNH_474098 & $\begin{array}{c}\text { Dysithamnus mentalis } \\
\text { tambillanus }\end{array}$ & Amazonas & YES & YES \\
\hline 0262 & FMNH_474099 & $\begin{array}{c}\text { Dysithamnus mentalis } \\
\text { tambillanus }\end{array}$ & Amazonas & & YES \\
\hline 0263 & FMNH_474100 & $\begin{array}{c}\text { Dysithamnus mentalis } \\
\text { tambillanus }\end{array}$ & Amazonas & YES & YES \\
\hline 0264 & FMNH_474102 & $\begin{array}{c}\text { Dysithamnus mentalis } \\
\text { tambillanus }\end{array}$ & Amazonas & & YES \\
\hline 0265 & FMNH_474103 & $\begin{array}{c}\text { Dysithamnus mentalis } \\
\text { tambillanus } \\
\end{array}$ & Amazonas & & YES \\
\hline 0266 & FMNH_474104 & $\begin{array}{c}\text { Dysithamnus mentalis } \\
\text { tambillanus }\end{array}$ & Amazonas & & YES \\
\hline 0267 & FMNH_481065 & $\begin{array}{c}\text { Dysithamnus mentalis } \\
\text { tambillanus }\end{array}$ & Cajamarca & YES & YES \\
\hline 0268 & ML 1862 & Lochmias nematura & Minas Gerais & YES & YES \\
\hline 0269 & ML 1863 & Lochmias nematura & Minas Gerais & YES & YES \\
\hline 0270 & ESS_196 & Lochmias nematura & Santa Catarina & YES & YES \\
\hline 0271 & ESS_198 & Lochmias nematura & Santa Catarina & & YES \\
\hline 0272 & ML 2030 & Thamnophilus caerulescens & Minas Gerais & YES & YES \\
\hline 0273 & ML 2031 & Thamnophilus caerulescens & Goiás & YES & YES \\
\hline 0274 & BOR-14-23 & Dysithamnus mentalis & São Paulo & & YES \\
\hline 0275 & BOR-14-32 & Thamnophilus caerulescens & São Paulo & & YES \\
\hline 0276 & RM_06 & Lochmias nematura & Minas Gerais & YES & YES \\
\hline 0277 & MZ_85248 & $\begin{array}{c}\text { Xiphocolaptes albicollis } \\
\text { albicollis } \\
\end{array}$ & São Paulo & YES & YES \\
\hline 0278 & MZ_95442 & Xiphocolaptes carajaensis & Pará & YES & YES \\
\hline 0279 & MZ_92713 & $\begin{array}{c}\text { Xiphocolaptes } \\
\text { promeropirhynchus paraensis }\end{array}$ & Amazonas & & YES \\
\hline 0280 & MZ_92714 & $\begin{array}{c}\text { Xiphocolaptes } \\
\text { promeropirhynchus paraensis }\end{array}$ & Amazonas & & YES \\
\hline
\end{tabular}




\begin{tabular}{|c|c|c|c|c|c|}
\hline $\begin{array}{l}\text { Internal } \\
\text { number }\end{array}$ & $\begin{array}{c}\text { number/field } \\
\text { number }\end{array}$ & $\begin{array}{c}\text { Taxon } \\
\end{array}$ & State & $\begin{array}{c}\text { UCEs } \\
\text { Sequences }\end{array}$ & $\begin{array}{c}\text { ND2 } \\
\text { Sequences }\end{array}$ \\
\hline 0281 & MZ_99818 & $\begin{array}{c}\text { Xiphocolaptes } \\
\text { promeropirhynchus berlepschi }\end{array}$ & Rondônia & & YES \\
\hline 0282 & BML_444 & Xiphocolaptes carajaensis & Pará & YES & YES \\
\hline 0283 & ML_2032 & Thamnophilus caerulescens & Minas Gerais & & YES \\
\hline 0284 & MCP_2896 & Thamnophilus ruficapillus & Rio Grande do Sul & YES & YES \\
\hline 0285 & MCP_3110 & Thamnophilus ruficapillus & Rio Grande do Sul & YES & YES \\
\hline 0286 & MCP_3189 & Thamnophilus ruficapillus & Rio Grande do Sul & & YES \\
\hline 0287 & MCP_3190 & Thamnophilus ruficapillus & Rio Grande do Sul & & YES \\
\hline 0288 & MCP_3306 & Thamnophilus caerulescens & Rio Grande do Sul & YES & YES \\
\hline 0290 & MCP_3509 & Thamnophilus caerulescens & Rio Grande do Sul & & YES \\
\hline 0291 & MCP_4038 & Thamnophilus ruficapillus & Rio Grande do Sul & & YES \\
\hline 0292 & MCP_4051 & Lochmias nematura & Rio Grande do Sul & & YES \\
\hline 0293 & MCP_4053 & Thamnophilus caerulescens & Rio Grande do Sul & & YES \\
\hline 0294 & MCP_4058 & Thamnophilus ruficapillus & Rio Grande do Sul & & YES \\
\hline 0295 & MCP_4085 & Dysithamnus mentalis & Mato Grosso & & YES \\
\hline 0296 & MCP_4129 & Thamnophilus ruficapillus & Rio Grande do Sul & YES & YES \\
\hline 0297 & MCP_4389 & Philydor rufum & Rio Grande do Sul & YES & YES \\
\hline 0298 & MCP_4679 & Dysithamnus mentalis & Santa Catarina & & YES \\
\hline 0299 & MCP_4843 & Thamnophilus caerulescens & Santa Catarina & YES & YES \\
\hline 0300 & MZ_70025 & $\begin{array}{c}\text { Thamnophilus caerulescens } \\
\text { ochraceiventer }\end{array}$ & Goiás & & \\
\hline 0306 & ML_2030 & Thamnophilus caerulescens & Minas Gerais & & \\
\hline 0307 & ML_2031 & Thamnophilus caerulescens & Goiás & & \\
\hline 0309 & MPEG_T01670 & Thamnophilus palliatus & Pará & YES & YES \\
\hline 0310 & MPEG_T01987 & Philydor rufum & Acre & YES & YES \\
\hline 0311 & MPEG_T02234 & Dysithamnus mentalis & Pará & YES & YES \\
\hline 0312 & MPEG_T02538 & $\begin{array}{c}\text { Xiphocolaptes } \\
\text { promeropirhynchus }\end{array}$ & Pará & YES & YES \\
\hline 0313 & MPEG_T03450 & Dysithamnus mentalis & Mato Grosso & YES & YES \\
\hline 0314 & MPEG_T04522 & $\begin{array}{c}\text { Xiphocolaptes } \\
\text { promeropirhynchus }\end{array}$ & Mato Grosso & YES & YES \\
\hline 0315 & MPEG_T06852 & Thamnophilus torquatus & Piauí & & YES \\
\hline 0316 & MPEG_T06873 & Thamnophilus torquatus & Piauí & YES & YES \\
\hline 0317 & MPEG_T06905 & Thamnophilus torquatus & Piauí & YES & YES \\
\hline 0318 & MPEG_T06924 & Thamnophilus torquatus & Piauí & YES & YES \\
\hline 0319 & MPEG_T08265 & Xiphocolaptes falcirostris & Maranhão & YES & YES \\
\hline 0323 & MPEG_T09657 & Thamnophilus torquatus & Piauí & YES & YES \\
\hline 0325 & MPEG_T09706 & Dysithamnus mentalis & Piauí & & YES \\
\hline 0326 & MPEG_T09855 & Dysithamnus mentalis & Piauí & & YES \\
\hline 0327 & MPEG_T09867 & Dysithamnus mentalis & Piauí & & YES \\
\hline 0328 & MPEG_T10072 & Thamnophilus torquatus & Piauí & & YES \\
\hline
\end{tabular}




\begin{tabular}{|c|c|c|c|c|c|}
\hline $\begin{array}{l}\text { Internal } \\
\text { number }\end{array}$ & $\begin{array}{c}\text { number/field } \\
\text { number }\end{array}$ & Taxon & State & $\begin{array}{c}\text { UCEs } \\
\text { Sequences }\end{array}$ & $\begin{array}{c}\text { ND2 } \\
\text { Sequences }\end{array}$ \\
\hline 0329 & MPEG_T10588 & $\begin{array}{c}\text { Xiphocolaptes } \\
\text { promeropirhynchus }\end{array}$ & Mato Grosso & YES & YES \\
\hline 0332 & MPEG_T11172 & Thamnophilus palliatus & Mato Grosso & YES & YES \\
\hline 0333 & MPEG_T11577 & $\begin{array}{c}\text { Xiphocolaptes } \\
\text { promeropirhynchus }\end{array}$ & Mato Grosso & & YES \\
\hline 0335 & MPEG_T12338 & $\begin{array}{c}\text { Xiphocolaptes } \\
\text { promeropirhynchus }\end{array}$ & Pará & & YES \\
\hline 0336 & MPEG_T12490 & Thamnophilus palliatus & Pará & YES & YES \\
\hline 0337 & MPEG_T12505 & Dysithamnus mentalis & Pará & & YES \\
\hline 0338 & MPEG_T12705 & Thamnophilus palliatus & Alagoas & YES & YES \\
\hline 0340 & MPEG_T12861 & Dysithamnus mentalis & Maranhão & & \\
\hline 0341 & MPEG_T12901 & Dysithamnus mentalis & Maranhão & & YES \\
\hline 0342 & MPEG_T12907 & Dysithamnus mentalis & Maranhão & & YES \\
\hline 0343 & MPEG_T12923 & Thamnophilus palliatus & Maranhão & YES & YES \\
\hline 0344 & MPEG_T12995 & Xiphocolaptes falcirostris & Piauí & YES & YES \\
\hline 0347 & MPEG_T13444 & Thamnophilus palliatus & Bahia & YES & YES \\
\hline 0349 & MPEG_T14940 & Thamnophilus caerulescens & Santa Catarina & YES & YES \\
\hline 0351 & MPEG_T14991 & Thamnophilus caerulescens & Santa Catarina & & YES \\
\hline 0352 & MPEG_T15045 & Xiphocolaptes albicollis & Santa Catarina & YES & YES \\
\hline 0353 & MPEG_T15046 & Philydor rufum & Santa Catarina & & YES \\
\hline 0354 & MPEG_T15047 & Philydor rufum & Santa Catarina & YES & YES \\
\hline 0355 & MPEG_T15048 & Philydor rufum & Santa Catarina & & YES \\
\hline 0356 & MPEG_T15060 & Dysithamnus mentalis & Santa Catarina & & YES \\
\hline 0357 & MPEG_T15076 & Lochmias nematura & Santa Catarina & YES & YES \\
\hline 0358 & MPEG_T15078 & Dysithamnus mentalis & Santa Catarina & & YES \\
\hline 0359 & MPEG_T15098 & Dysithamnus mentalis & Santa Catarina & YES & YES \\
\hline 0361 & MPEG_T15175 & Dysithamnus mentalis & Piauí & YES & YES \\
\hline 0362 & MPEG_T15178 & Dysithamnus mentalis & Piauí & & \\
\hline 0363 & MPEG_T15207 & Thamnophilus caerulescens & Pernambuco & & YES \\
\hline 0364 & MPEG_T15223 & Dysithamnus mentalis & Minas Gerais & & YES \\
\hline 0365 & MPEG_T15230 & Dysithamnus mentalis & Minas Gerais & & YES \\
\hline 0366 & MPEG_T15231 & Dysithamnus mentalis & Minas Gerais & & YES \\
\hline 0367 & MPEG_T15287 & Dysithamnus mentalis & Mato Grosso & YES & YES \\
\hline 0368 & MPEG_T15288 & Dysithamnus mentalis & Mato Grosso & YES & YES \\
\hline 0369 & MPEG_T15289 & Dysithamnus mentalis & Mato Grosso & YES & YES \\
\hline 0370 & MPEG_T15352 & Dysithamnus mentalis & Goiás & & YES \\
\hline 0371 & MPEG_T15353 & Dysithamnus mentalis & Goiás & & YES \\
\hline 0372 & MPEG_T15413 & Thamnophilus torquatus & Minas Gerais & & YES \\
\hline 0373 & MPEG_T15414 & Thamnophilus torquatus & Minas Gerais & YES & YES \\
\hline 0374 & MPEG_T15415 & Thamnophilus torquatus & Minas Gerais & YES & YES \\
\hline
\end{tabular}




\begin{tabular}{|c|c|c|c|c|c|}
\hline $\begin{array}{l}\text { Internal } \\
\text { number }\end{array}$ & $\begin{array}{c}\text { number/field } \\
\text { number }\end{array}$ & Taxon & State & $\begin{array}{c}\text { UCEs } \\
\text { Sequences }\end{array}$ & $\begin{array}{c}\text { ND2 } \\
\text { Sequences } \\
\end{array}$ \\
\hline 0375 & MPEG_T15453 & Dysithamnus mentalis & Mato Grosso & & YES \\
\hline 0376 & MPEG_T15454 & Dysithamnus mentalis & Mato Grosso & & YES \\
\hline 0377 & MPEG_T15455 & Dysithamnus mentalis & Mato Grosso & & YES \\
\hline 0381 & MPEG_T15530 & Dysithamnus mentalis & Mato Grosso & & YES \\
\hline 0386 & MPEG_T15661 & Dysithamnus mentalis & Tocantins & YES & YES \\
\hline 0387 & MPEG_T15662 & Dysithamnus mentalis & Tocantins & & YES \\
\hline 0388 & MPEG_T15683 & Philydor rufum & Minas Gerais & & \\
\hline 0389 & MPEG_T15689 & Lochmias nematura & Minas Gerais & & YES \\
\hline 0390 & MPEG_T15691 & Thamnophilus caerulescens & Minas Gerais & YES & YES \\
\hline 0392 & MPEG_T15720 & Thamnophilus caerulescens & Minas Gerais & & YES \\
\hline 0395 & MPEG_T15741 & Thamnophilus torquatus & Minas Gerais & YES & YES \\
\hline 0396 & MPEG_T15750 & Dysithamnus mentalis & Minas Gerais & & YES \\
\hline 0397 & MPEG_T15751 & Dysithamnus mentalis & Minas Gerais & & YES \\
\hline 0398 & MPEG_T15752 & Dysithamnus mentalis & Minas Gerais & & YES \\
\hline 0399 & MPEG_T15762 & Philydor rufum & Minas Gerais & & YES \\
\hline 0400 & MPEG_T15783 & Thamnophilus caerulescens & Minas Gerais & & YES \\
\hline 0401 & MPEG_T15786 & Philydor rufum & Minas Gerais & YES & YES \\
\hline 0402 & MPEG_T15792 & Dysithamnus mentalis & Minas Gerais & & \\
\hline 0403 & MPEG_T16708 & $\begin{array}{c}\text { Xiphocolaptes } \\
\text { promeropirhynchus }\end{array}$ & Pará & & YES \\
\hline 0404 & MPEG_T18772 & $\begin{array}{c}\text { Xiphocolaptes } \\
\text { promeropirhynchus }\end{array}$ & Pará & & YES \\
\hline 0405 & MPEG_T18835 & $\begin{array}{c}\text { Xiphocolaptes } \\
\text { promeropirhynchus }\end{array}$ & Pará & & YES \\
\hline 0408 & MPEG_T19396 & $\begin{array}{c}\text { Xiphocolaptes } \\
\text { promeropirhynchus }\end{array}$ & Pará & & YES \\
\hline 0409 & MPEG_T19397 & $\begin{array}{c}\text { Xiphocolaptes } \\
\text { promeropirhynchus }\end{array}$ & Pará & & YES \\
\hline 0410 & MPEG_T19427 & $\begin{array}{c}\text { Xiphocolaptes } \\
\text { promeropirhynchus }\end{array}$ & Pará & & YES \\
\hline 0411 & MPEG_T19876 & Dysithamnus mentalis & Maranhão & & YES \\
\hline 0412 & MPEG_T19877 & Dysithamnus mentalis & Maranhão & & YES \\
\hline 0413 & MPEG_T19906 & Dysithamnus mentalis & Maranhão & & YES \\
\hline 0414 & MPEG_T19916 & Thamnophilus palliatus & Maranhão & & YES \\
\hline 0415 & MPEG_T20164 & Xiphocolaptes falcirostris & Piauí & & YES \\
\hline 0416 & MPEG_T20167 & Xiphocolaptes falcirostris & Piauí & YES & YES \\
\hline 0417 & MPEG_T21092 & Dysithamnus mentalis & Minas Gerais & & YES \\
\hline 0418 & MPEG_T21098 & Thamnophilus caerulescens & Minas Gerais & & \\
\hline 0419 & MPEG_T21113 & Lochmias nematura & Minas Gerais & YES & YES \\
\hline 0420 & MPEG_T21152 & Dysithamnus mentalis & Tocantins & & YES \\
\hline 0421 & MPEG_T21155 & Dysithamnus mentalis & Tocantins & YES & YES \\
\hline 0422 & MPEG_T21161 & Dysithamnus mentalis & Tocantins & & YES \\
\hline
\end{tabular}




\begin{tabular}{|c|c|c|c|c|c|}
\hline $\begin{array}{l}\text { Internal } \\
\text { number }\end{array}$ & $\begin{array}{c}\text { number/field } \\
\text { number }\end{array}$ & Taxon & State & $\begin{array}{c}\text { UCEs } \\
\text { Sequences }\end{array}$ & $\begin{array}{c}\text { ND2 } \\
\text { Sequences } \\
\end{array}$ \\
\hline 0423 & MPEG_T21639 & Dysithamnus mentalis & Tocantins & & \\
\hline 0424 & MPEG_T21651 & Dysithamnus mentalis & Tocantins & YES & YES \\
\hline 0425 & MPEG_T21688 & Dysithamnus mentalis & Tocantins & & YES \\
\hline 0426 & MPEG_T21702 & Dysithamnus mentalis & Tocantins & & YES \\
\hline 0427 & MPEG_T23067 & Thamnophilus palliatus & Mato Grosso & YES & YES \\
\hline 0428 & MPEG_T23096 & Dysithamnus mentalis & Tocantins & & YES \\
\hline 0429 & MPEG_T23098 & Dysithamnus mentalis & Tocantins & & YES \\
\hline 0430 & MPEG_T23718 & Thamnophilus palliatus & Pará & YES & YES \\
\hline 0431 & MPEG_T23982 & Dysithamnus mentalis & Bahia & & YES \\
\hline 0432 & MPEG_T23983 & Dysithamnus mentalis & Bahia & & YES \\
\hline 0437 & MPEG_T24942 & $\begin{array}{c}\text { Xiphocolaptes } \\
\text { promeropirhynchus }\end{array}$ & Amazonas & & YES \\
\hline 0438 & MPEG_T24997 & Dysithamnus mentalis & Pará & & YES \\
\hline 0439 & ML_5532 & Philydor rufum & Santa Catarina & & YES \\
\hline 0440 & ML_5546 & Thamnophilus caerulescens & Santa Catarina & & YES \\
\hline 0442 & ML_5590 & Philydor rufum & Santa Catarina & & YES \\
\hline 0443 & UFG_4978 & Platyrinchus mystaceus & Maranhão & & YES \\
\hline 0444 & LSUB_12144 & Thamnophilus unicolor & Ecuador & YES & YES \\
\hline 0445 & BO475_EU295760 & Thamnophilus caerulescens & Minas Gerais & & YES \\
\hline 0446 & BO513_EU295759 & Thamnophilus caerulescens & Minas Gerais & & YES \\
\hline 0447 & FMNH_395426 & Thamnophilus caerulescens & São Paulo & & YES \\
\hline 0448 & LSUB_1684 & Thamnophilus caerulescens & Pasco & & YES \\
\hline 0449 & LSU_38284 & Thamnophilus caerulescens & Santa Cruz & & YES \\
\hline 0450 & MPEG_CPEII037 & Thamnophilus caerulescens & Pernambuco & YES & YES \\
\hline 0451 & MZ_81155 & Thamnophilus caerulescens & São Paulo & & YES \\
\hline 0452 & MZ_84352 & Thamnophilus caerulescens & Santa Catarina & & YES \\
\hline 0453 & UWBM_77213 & Thamnophilus caerulescens & Tarija & YES & YES \\
\hline 0454 & UWBMRTB_407 & Thamnophilus caerulescens & Cochabamba & & YES \\
\hline 0455 & $\begin{array}{c}\text { YPM_10106_KJ_81 } \\
0434\end{array}$ & Thamnophilus caerulescens & Artigas & & YES \\
\hline 0456 & MZ_90922 & Dysithamnus stictothorax & Bahia & & YES \\
\hline 0457 & AMC_1266 & Dysithamnus mentalis & Tachira & & YES \\
\hline 0458 & AMC_1310 & Dysithamnus mentalis & Tachira & & YES \\
\hline 0459 & JM_1042 & Dysithamnus mentalis & Tachira & & YES \\
\hline 0460 & JM_1102 & Dysithamnus mentalis & Tachira & & YES \\
\hline 0461 & JPL_340 & Dysithamnus mentalis & Tachira & & YES \\
\hline 0462 & JPL_341 & Dysithamnus mentalis & Tachira & & YES \\
\hline 0463 & KCC__160 & Dysithamnus mentalis & Tachira & & YES \\
\hline 0464 & KCC_178 & Dysithamnus mentalis & Tachira & & YES \\
\hline
\end{tabular}




\begin{tabular}{|c|c|c|c|c|c|}
\hline $\begin{array}{l}\text { Internal } \\
\text { number }\end{array}$ & $\begin{array}{c}\text { number/field } \\
\text { number }\end{array}$ & Taxon & State & $\begin{array}{c}\text { UCEs } \\
\text { Sequences }\end{array}$ & $\begin{array}{c}\text { ND2 } \\
\text { Sequences } \\
\end{array}$ \\
\hline 0465 & KCC_246 & Dysithamnus mentalis & Tachira & & YES \\
\hline 0466 & KCC_248 & Dysithamnus mentalis & Tachira & & YES \\
\hline 0467 & KCC_255 & Dysithamnus mentalis & Tachira & & YES \\
\hline 0468 & FMNH_293443 & Dysithamnus mentalis & Pernambuco & & YES \\
\hline 0469 & IAvH_BT_112 & Dysithamnus mentalis & Norte de Santander & & YES \\
\hline 0470 & IAvH_BT_114 & Dysithamnus mentalis & Norte de Santander & & YES \\
\hline 0471 & LSU_72027 & Dysithamnus mentalis & Costa Rica? & & YES \\
\hline 0472 & LSUB_25839 & Dysithamnus mentalis & Caaguazu & & YES \\
\hline 0473 & LSUB_26463 & Dysithamnus mentalis & Chiquiri & YES & YES \\
\hline 0474 & LSUB_43612 & Dysithamnus mentalis & San Martin & & YES \\
\hline 0475 & LSUB_48490 & Dysithamnus mentalis & Guyana & YES & YES \\
\hline 0476 & LSYUB_33085 & Dysithamnus mentalis & Cajamarca & YES & YES \\
\hline 0477 & ML_2720 & Platyrinchus mystaceus & Alagoas & & \\
\hline 0478 & ML_2721 & Platyrinchus mystaceus & Alagoas & & \\
\hline 0479 & ML_2731 & Platyrinchus mystaceus & Alagoas & & \\
\hline 0480 & ML_2732 & Platyrinchus mystaceus & Alagoas & & \\
\hline 0481 & ML_2716 & Dysithamnus mentalis & Alagoas & & YES \\
\hline 0482 & ML_2733 & Dysithamnus mentalis & Alagoas & YES & YES \\
\hline 0483 & ML_2736 & Dysithamnus mentalis & Alagoas & & YES \\
\hline 0484 & ML_2768 & Dysithamnus mentalis & Alagoas & & YES \\
\hline 0485 & $\begin{array}{c}\text { AMNH_12074_JF9 } \\
75324 \\
\end{array}$ & Lochmias nematura & Misiones & YES & YES \\
\hline 0486 & $\begin{array}{c}\text { LSU_38510_KF705 } \\
454 \\
\end{array}$ & Lochmias nematura & SantaCruz & YES & YES \\
\hline 0487 & GQ906717 & Xiphocolaptes major & SantaCruz & & YES \\
\hline 0488 & UWBMMAB02 & Thamnophilus palliatus & SantaCruz & & YES \\
\hline 0489 & UWBMRTB390 & Thamnophilus doliatus & SantaCruz & & YES \\
\hline 0490 & LSUB38230 & Thamnophilus ruficapillus & SantaCruz & YES & YES \\
\hline 0491 & UWBMRTB347 & Thamnophilus ruficapillus & SantaCruz & & YES \\
\hline 0492 & LSUB13900 & Thamnophilus torquatus & SantaCruz & YES & YES \\
\hline 0493 & LSUB14631 & Thamnophilus torquatus & SantaCruz & & YES \\
\hline 0494 & MZ_85427 & Thamnophilus ruficapillus & Minas Gerais & & YES \\
\hline 0495 & $\begin{array}{c}\text { MPEG_55411_T16 } \\
70\end{array}$ & Thamnophilus palliatus & Pará & & YES \\
\hline 0496 & $\begin{array}{c}\text { LSUMZ_B35610_K } \\
\text { F705463 }\end{array}$ & $\begin{array}{c}\text { Xiphocolaptes } \\
\text { promeropirhynchus }\end{array}$ & Pará & YES & YES \\
\hline 0497 & $\begin{array}{c}\text { LGEMA_P2333_JF } \\
975343 \\
\end{array}$ & Xiphocolaptes falcirostris & Piauí & YES & YES \\
\hline 0498 & $\mathrm{IAvH} 2379$ & Thamnophilus multistriatus & Valle & & YES \\
\hline 0499 & IAvH8245 & Thamnophilus palliatus & Vichada & YES & YES \\
\hline 0500 & ANSP1686 & Thamnophilus tenuepunctatus & Ecuador & YES & YES \\
\hline
\end{tabular}




\begin{tabular}{|c|c|c|c|c|c|}
\hline $\begin{array}{l}\text { Internal } \\
\text { number }\end{array}$ & $\begin{array}{c}\text { number/field } \\
\text { number }\end{array}$ & Taxon & State & $\begin{array}{c}\text { UCEs } \\
\text { Sequences }\end{array}$ & $\begin{array}{c}\text { ND2 } \\
\text { Sequences }\end{array}$ \\
\hline 0501 & KF705462 & $\begin{array}{c}\text { Xiphocolaptes } \\
\text { promeropirhynchus }\end{array}$ & Honduras & & YES \\
\hline 0502 & $\begin{array}{c}\text { SI_607841_EF5018 } \\
89 \\
\end{array}$ & Platyrinchus mystaceus & Panamá & & YES \\
\hline 0503 & AY089872 & $\begin{array}{c}\text { Xiphocolaptes } \\
\text { promeropirhynchus }\end{array}$ & Cajamarca & & YES \\
\hline 0504 & JF975342 & $\begin{array}{c}\text { Xiphocolaptes } \\
\text { promeropirhynchus }\end{array}$ & Cajamarca & & YES \\
\hline 0505 & LSUB32657 & Thamnophilus ruficapillus & Cajamarca & YES & YES \\
\hline 0506 & $\begin{array}{c}\text { LSU_40199_JF975 } \\
306 \\
\end{array}$ & Philydor rufum & Loreto & YES & YES \\
\hline 0507 & LSUB58400 & Thamnophilus palliatus & Puno & YES & YES \\
\hline 0508 & LSUB58333 & Thamnophilus ruficapillus & Puno & YES & YES \\
\hline 0509 & LSUB44648 & Thamnophilus tenuepunctatus & San Martin & YES & YES \\
\hline 0510 & JF975349 & Dendrocolaptes platyrostris & Paraguay & & YES \\
\hline 0511 & $\begin{array}{c}\text { LSUMZ_25944_JF } \\
975344\end{array}$ & Xiphocolaptes albicollis & Paraguay & YES & YES \\
\hline 0512 & $\begin{array}{c}\text { NRM_976724_KF2 } \\
28509\end{array}$ & Platyrinchus mystaceus & Concepcion & & YES \\
\hline 0515 & $\begin{array}{c}\text { YPM_1141_KJ8103 } \\
87\end{array}$ & Lochmias nematura & Uruguay & & YES \\
\hline 0516 & $\begin{array}{c}\text { LSU_7481_HM125 } \\
593\end{array}$ & Lochmias nematura & Amazonas & & YES \\
\hline 0518 & Pla_mys_28375 & Platyrinchus mystaceus & Panama & & YES \\
\hline 0519 & LSUMZ_25794 & Xiphocolaptes major & Paraguay & YES & YES \\
\hline 0520 & Xip_pro_4526 & $\begin{array}{c}\text { Xiphocolaptes } \\
\text { promeropirhynchus }\end{array}$ & Loreto & & YES \\
\hline 0521 & Xip_pro_7998 & $\begin{array}{c}\text { Xiphocolaptes } \\
\text { promeropirhynchus }\end{array}$ & Pasco & & YES \\
\hline 0522 & Xip_pro_41765 & $\begin{array}{c}\text { Xiphocolaptes } \\
\text { promeropirhynchus }\end{array}$ & Cochabamba & & YES \\
\hline 0523 & MZ_92166 & $\begin{array}{c}\text { Platyrinchus mystaceus } \\
\text { mystaceus }\end{array}$ & São Paulo & & \\
\hline 0524 & MZ_92167 & $\begin{array}{c}\text { Platyrinchus mystaceus } \\
\text { mystaceus }\end{array}$ & São Paulo & & \\
\hline 0525 & MZ_92484 & $\begin{array}{c}\text { Platyrinchus mystaceus } \\
\text { mystaceus }\end{array}$ & São Paulo & & \\
\hline 0526 & MZ_92485 & $\begin{array}{c}\text { Platyrinchus mystaceus } \\
\text { mystaceus }\end{array}$ & São Paulo & & \\
\hline 0527 & MZ_92486 & $\begin{array}{c}\text { Platyrinchus mystaceus } \\
\text { mystaceus }\end{array}$ & São Paulo & & \\
\hline 0528 & MZ_93536 & $\begin{array}{c}\text { Platyrinchus mystaceus } \\
\text { mystaceus }\end{array}$ & São Paulo & & \\
\hline 0529 & MZ_93537 & $\begin{array}{c}\text { Platyrinchus mystaceus } \\
\text { mystaceus }\end{array}$ & São Paulo & & \\
\hline 0530 & MZ_93538 & $\begin{array}{c}\text { Platyrinchus mystaceus } \\
\text { mystaceus }\end{array}$ & São Paulo & & \\
\hline 0531 & BOR 14-46 & $\begin{array}{c}\text { Platyrinchus mystaceus } \\
\text { mystaceus }\end{array}$ & São Paulo & & YES \\
\hline 0532 & BOR 14-78 & $\begin{array}{c}\text { Platyrinchus mystaceus } \\
\text { mystaceus }\end{array}$ & São Paulo & & YES \\
\hline 0533 & SM_04 & $\begin{array}{c}\text { Platyrinchus mystaceus } \\
\text { mystaceus }\end{array}$ & São Paulo & & YES \\
\hline 0534 & BOR 14-05 & $\begin{array}{c}\text { Platyrinchus mystaceus } \\
\text { mystaceus }\end{array}$ & São Paulo & & YES \\
\hline
\end{tabular}




\begin{tabular}{|c|c|c|c|c|c|}
\hline $\begin{array}{l}\text { Internal } \\
\text { number }\end{array}$ & $\begin{array}{c}\text { number/field } \\
\text { number }\end{array}$ & Taxon & State & $\begin{array}{c}\text { UCEs } \\
\text { Sequences }\end{array}$ & $\begin{array}{c}\text { ND2 } \\
\text { Sequences }\end{array}$ \\
\hline 0535 & MZ_94442 & $\begin{array}{c}\text { Platyrinchus mystaceus } \\
\text { cancromus }\end{array}$ & Minas Gerais & & \\
\hline 0536 & UFG_4483 & $\begin{array}{c}\text { Platyrinchus mystaceus } \\
\text { cancromus }\end{array}$ & Maranhão & YES & \\
\hline 0537 & MCP_5493 & $\begin{array}{c}\text { Platyrinchus mystaceus } \\
\text { cancromus }\end{array}$ & Santa Catarina & & YES \\
\hline 0538 & MCP_5495 & $\begin{array}{c}\text { Platyrinchus mystaceus } \\
\text { cancromus }\end{array}$ & Santa Catarina & & YES \\
\hline 0539 & MCP_5514 & $\begin{array}{c}\text { Platyrinchus mystaceus } \\
\text { cancromus }\end{array}$ & Santa Catarina & YES & YES \\
\hline 0540 & MCP_5527 & $\begin{array}{c}\text { Platyrinchus mystaceus } \\
\text { cancromus }\end{array}$ & Santa Catarina & YES & YES \\
\hline 0541 & ALG-159 & $\begin{array}{c}\text { Platyrinchus mystaceus } \\
\text { niveigularis }\end{array}$ & Alagoas & & YES \\
\hline 0542 & ALG-158 & $\begin{array}{c}\text { Platyrinchus mystaceus } \\
\text { niveigularis }\end{array}$ & Alagoas & & YES \\
\hline 0543 & ALG-39 & $\begin{array}{c}\text { Platyrinchus mystaceus } \\
\text { niveigularis }\end{array}$ & Alagoas & & YES \\
\hline 0544 & ALG-48 & $\begin{array}{c}\text { Platyrinchus mystaceus } \\
\text { niveigularis }\end{array}$ & Alagoas & & YES \\
\hline 0545 & FMNH_427096 & $\begin{array}{c}\text { Platyrinchus mystaceus } \\
\text { niveigularis }\end{array}$ & Pernambuco & & YES \\
\hline 0546 & FMNH_427097 & $\begin{array}{c}\text { Platyrinchus mystaceus } \\
\text { niveigularis }\end{array}$ & Pernambuco & & YES \\
\hline 0547 & FMNH_427098 & $\begin{array}{c}\text { Platyrinchus mystaceus } \\
\text { niveigularis }\end{array}$ & Pernambuco & & YES \\
\hline 0548 & FMNH_427099 & $\begin{array}{c}\text { Platyrinchus mystaceus } \\
\text { niveigularis }\end{array}$ & Pernambuco & & YES \\
\hline 0549 & FMNH_427100 & $\begin{array}{c}\text { Platyrinchus mystaceus } \\
\text { niveigularis }\end{array}$ & Pernambuco & YES & YES \\
\hline 0550 & FMNH_427101 & $\begin{array}{c}\text { Platyrinchus mystaceus } \\
\text { niveigularis }\end{array}$ & Alagoas & & YES \\
\hline 0551 & FMNH_427102 & $\begin{array}{c}\text { Platyrinchus mystaceus } \\
\text { niveigularis } \\
\end{array}$ & Alagoas & & YES \\
\hline 0552 & FMNH_427103 & $\begin{array}{c}\text { Platyrinchus mystaceus } \\
\text { niveigularis }\end{array}$ & Alagoas & & YES \\
\hline 0553 & FMNH_427104 & $\begin{array}{c}\text { Platyrinchus mystaceus } \\
\text { niveigularis }\end{array}$ & Alagoas & & YES \\
\hline 0554 & FMNH_427105 & $\begin{array}{c}\text { Platyrinchus mystaceus } \\
\text { niveigularis }\end{array}$ & Alagoas & & YES \\
\hline 0555 & FMNH_427106 & $\begin{array}{c}\text { Platyrinchus mystaceus } \\
\text { niveigularis }\end{array}$ & Alagoas & & YES \\
\hline 0556 & MCP_3089 & $\begin{array}{c}\text { Platyrinchus mystaceus } \\
\text { mystaceus }\end{array}$ & Rio Grande do Sul & YES & YES \\
\hline 0557 & MCP_4699 & $\begin{array}{c}\text { Platyrinchus mystaceus } \\
\text { cancromus }\end{array}$ & Santa Catarina & & YES \\
\hline 0558 & MPEG_68442 & $\begin{array}{c}\text { Platyrinchus mystaceus } \\
\text { cancromus }\end{array}$ & Maranhão & & \\
\hline 0559 & MPEG_68441 & $\begin{array}{c}\text { Platyrinchus mystaceus } \\
\text { cancromus }\end{array}$ & Maranhão & & \\
\hline 0560 & LZUFPI_0174 & $\begin{array}{c}\text { Platyrinchus mystaceus } \\
\text { cancromus }\end{array}$ & Piauí & YES & YES \\
\hline 0561 & LZUFPI_0176 & $\begin{array}{c}\text { Platyrinchus mystaceus } \\
\text { cancromus }\end{array}$ & Piauí & & \\
\hline 0562 & LZUFPI_0322 & $\begin{array}{c}\text { Platyrinchus mystaceus } \\
\text { cancromus }\end{array}$ & Piauí & & \\
\hline 0563 & COUFT_0515 & $\begin{array}{c}\text { Platyrinchus mystaceus } \\
\text { cancromus }\end{array}$ & Tocantins & YES & YES \\
\hline
\end{tabular}




\begin{tabular}{|c|c|c|c|c|c|}
\hline $\begin{array}{l}\text { Internal } \\
\text { number }\end{array}$ & $\begin{array}{c}\text { number/field } \\
\text { number }\end{array}$ & Taxon & State & $\begin{array}{c}\text { UCEs } \\
\text { Sequences }\end{array}$ & $\begin{array}{c}\text { ND2 } \\
\text { Sequences }\end{array}$ \\
\hline 0564 & MPEG_T23638 & $\begin{array}{c}\text { Platyrinchus mystaceus } \\
\text { cancromus }\end{array}$ & Piauí & YES & YES \\
\hline 0565 & MPEG_70184 & $\begin{array}{c}\text { Platyrinchus mystaceus } \\
\text { cancromus }\end{array}$ & Maranhão & YES & YES \\
\hline 0566 & MPEG_DZ_4934 & $\begin{array}{c}\text { Platyrinchus mystaceus } \\
\text { cancromus }\end{array}$ & Minas Gerais & YES & YES \\
\hline 0567 & MPEG_DZ_6768 & $\begin{array}{c}\text { Platyrinchus mystaceus } \\
\text { cancromus }\end{array}$ & Minas Gerais & & \\
\hline 0568 & DZ_4935 & $\begin{array}{c}\text { Platyrinchus mystaceus } \\
\text { cancromus }\end{array}$ & Minas Gerais & & YES \\
\hline 0569 & DZ_5020 & $\begin{array}{c}\text { Platyrinchus mystaceus } \\
\text { cancromus }\end{array}$ & Minas Gerais & YES & YES \\
\hline 0570 & DZ_6769 & $\begin{array}{c}\text { Platyrinchus mystaceus } \\
\text { cancromus }\end{array}$ & Minas Gerais & & \\
\hline 0571 & DZ_6772 & $\begin{array}{c}\text { Platyrinchus mystaceus } \\
\text { cancromus }\end{array}$ & Minas Gerais & YES & YES \\
\hline 0572 & DZ_6770 & $\begin{array}{c}\text { Platyrinchus mystaceus } \\
\text { cancromus }\end{array}$ & Minas Gerais & & YES \\
\hline 0573 & MPEG_74929 & $\begin{array}{c}\text { Platyrinchus mystaceus } \\
\text { cancromus }\end{array}$ & Pará & YES & YES \\
\hline 0574 & CFL-CO_122 & $\begin{array}{c}\text { Platyrinchus mystaceus } \\
\text { cancromus }\end{array}$ & Minas Gerais & & YES \\
\hline 0575 & MPEG_74360 & $\begin{array}{c}\text { Platyrinchus mystaceus } \\
\text { cancromus }\end{array}$ & Piauí & & \\
\hline 0576 & MPEG_79462 & $\begin{array}{c}\text { Platyrinchus mystaceus } \\
\text { cancromus }\end{array}$ & Tocantins & & YES \\
\hline 0577 & MPEG_79465 & $\begin{array}{c}\text { Platyrinchus mystaceus } \\
\text { cancromus }\end{array}$ & Tocantins & & YES \\
\hline 0578 & MPEG_79466 & $\begin{array}{c}\text { Platyrinchus mystaceus } \\
\text { cancromus }\end{array}$ & Tocantins & YES & YES \\
\hline 0579 & MPEG_79463 & $\begin{array}{c}\text { Platyrinchus mystaceus } \\
\text { cancromus }\end{array}$ & Tocantins & & YES \\
\hline 0580 & MPEG_72017 & $\begin{array}{c}\text { Platyrinchus mystaceus } \\
\text { cancromus } \\
\end{array}$ & Santa Catarina & & YES \\
\hline 0581 & MPEG_71977 & $\begin{array}{c}\text { Platyrinchus mystaceus } \\
\text { cancromus }\end{array}$ & Santa Catarina & & YES \\
\hline 0582 & MPEG_71978 & $\begin{array}{c}\text { Platyrinchus mystaceus } \\
\text { cancromus }\end{array}$ & Santa Catarina & & YES \\
\hline 0583 & DZ_6771 & $\begin{array}{c}\text { Platyrinchus mystaceus } \\
\text { cancromus }\end{array}$ & Minas Gerais & & YES \\
\hline 0584 & COUFT_0531 & $\begin{array}{c}\text { Platyrinchus mystaceus } \\
\text { cancromus }\end{array}$ & Tocantins & & YES \\
\hline 0585 & COUFT_0434 & $\begin{array}{c}\text { Platyrinchus mystaceus } \\
\text { cancromus }\end{array}$ & Tocantins & & YES \\
\hline 0586 & MPEG_74361 & $\begin{array}{c}\text { Platyrinchus mystaceus } \\
\text { cancromus }\end{array}$ & Piauí & & YES \\
\hline 0587 & MPEG_79461 & $\begin{array}{c}\text { Platyrinchus mystaceus } \\
\text { cancromus }\end{array}$ & Tocantins & YES & YES \\
\hline 0588 & MPEG_70476 & $\begin{array}{c}\text { Platyrinchus mystaceus } \\
\text { niveigularis }\end{array}$ & Alagoas & & YES \\
\hline 0589 & MPEG_71880 & $\begin{array}{c}\text { Platyrinchus mystaceus } \\
\text { mystaceus }\end{array}$ & Bahia & & YES \\
\hline 0590 & MPEG_71881 & $\begin{array}{c}\text { Platyrinchus mystaceus } \\
\text { mystaceus }\end{array}$ & Bahia & & YES \\
\hline 0591 & MPEG_76409 & $\begin{array}{c}\text { Platyrinchus m.c. } \\
\text { (platyrinchos) }\end{array}$ & Pará & & YES \\
\hline 0592 & MPEG_76444 & $\begin{array}{c}\text { Platyrinchus mystaceus } \\
\text { cancromus }\end{array}$ & Pará & YES & YES \\
\hline
\end{tabular}




\begin{tabular}{|c|c|c|c|c|c|}
\hline $\begin{array}{l}\text { Internal } \\
\text { number }\end{array}$ & $\begin{array}{c}\text { number/field } \\
\text { number }\end{array}$ & Taxon & State & $\begin{array}{c}\text { UCEs } \\
\text { Sequences }\end{array}$ & $\begin{array}{c}\text { ND2 } \\
\text { Sequences }\end{array}$ \\
\hline 0593 & FMNH_394013 & $\begin{array}{c}\text { Xiphocolaptes } \\
\text { promeropirhynchus }\end{array}$ & Hidalgo & YES & YES \\
\hline 0594 & $\begin{array}{c}\text { IAvH_14827_H114 } \\
42\end{array}$ & $\begin{array}{c}\text { Xiphocolaptes } \\
\text { promeropirhynchus }\end{array}$ & Norte de Santander & YES & YES \\
\hline 0595 & LSUMZ_105996 & $\begin{array}{c}\text { Dysithamnus mentalis } \\
\text { olivaceus }\end{array}$ & Pasco & YES & YES \\
\hline 0596 & IAvH-BT_4241 & Dysithamnus mentalis extremus & Valle del Cauca & YES & YES \\
\hline 0597 & IAvH-BT_34527 & $\begin{array}{c}\text { Dysithamnus mentalis } \\
\text { semicinereus }\end{array}$ & Antioquia & YES & YES \\
\hline 0598 & ANSP_185449 & Dysithamnus mentalis napensis & Napo & YES & YES \\
\hline 0599 & LSUMZ_162665 & Dysithamnus mentalis tavarae & $\mathrm{LaPaz}$ & YES & YES \\
\hline 0600 & LSUMZ_183140 & $\begin{array}{c}\text { Dysithamnus mentalis } \\
\text { aequatorialis }\end{array}$ & Tumbes & YES & YES \\
\hline 0601 & LSUMZ_45867 & Dysithamnus mentalis andrei & Trinidad & YES & YES \\
\hline 0602 & LSUMZ_46017 & Dysithamnus mentalis oberi & Tobago & YES & YES \\
\hline 0603 & LSUMZ_105988 & $\begin{array}{c}\text { Thamnophilus caerulescens } \\
\text { melanochrous }\end{array}$ & Pasco & YES & YES \\
\hline 0604 & LSUMZ_171295 & $\begin{array}{c}\text { Thamnophilus caerulescens } \\
\text { paraguayensis }\end{array}$ & Santa Cruz & YES & YES \\
\hline 0605 & LSUMZ_168944 & $\begin{array}{c}\text { Thamnophilus caerulescens } \\
\text { connectens }\end{array}$ & Santa Cruz & YES & YES \\
\hline 0606 & LSUMZ_170871 & $\begin{array}{c}\text { Thamnophilus caerulescens } \\
\text { subandinus }\end{array}$ & Loreto & YES & YES \\
\hline 0607 & LSUMZ_179678 & $\begin{array}{c}\text { Thamnophilus caerulescens } \\
\text { aspersiventer }\end{array}$ & Puno & YES & YES \\
\hline 0608 & MZUSP_81155 & $\begin{array}{c}\text { Thamnophilus caerulescens } \\
\text { caerulescens }\end{array}$ & São Paulo & YES & YES \\
\hline 0609 & LSUMZ_B1134 & Dysithamnus mentalis & La Paz & YES & YES \\
\hline 0610 & LSUMZ_B6155 & Dysithamnus mentalis & Morona-Santiago & YES & YES \\
\hline 0611 & LSUMZ_B13848 & Dysithamnus mentalis & Santa Cruz & YES & YES \\
\hline 0612 & LSUMZ_B38408 & Dysithamnus mentalis & Santa Cruz & YES & YES \\
\hline 0613 & LSUMZ_B38935 & Dysithamnus mentalis & Cochabamba & YES & YES \\
\hline 0614 & LSUMZ_B40022 & Dysithamnus mentalis & Loreto & YES & YES \\
\hline 0615 & LSUMZ_B68224 & Dysithamnus mentalis & Beni & YES & YES \\
\hline 0616 & LSUMZ_B72029 & Dysithamnus mentalis & Cartago & YES & YES \\
\hline 0617 & LSUMZ_B76452 & Dysithamnus mentalis & Ucayali & YES & YES \\
\hline 0618 & LSUMZ_B89140 & Dysithamnus mentalis & Ucayali & YES & YES \\
\hline 0619 & LSUMZ_B2033 & Lochmias nematura & Pasco & YES & YES \\
\hline 0620 & LSUMZ_B7488 & Lochmias nematura & Amazonas & YES & YES \\
\hline 0621 & LSUMZ_B22682 & Lochmias nematura & $\mathrm{La} \mathrm{Paz}$ & YES & YES \\
\hline 0622 & LSUMZ_B25963 & Lochmias nematura & Caazapa & YES & YES \\
\hline 0623 & LSUMZ_B33710 & Lochmias nematura & Cajamarca & YES & YES \\
\hline 0624 & LSUMZ_B43594 & Lochmias nematura & San Martin & YES & YES \\
\hline 0625 & LSUMZ_B48459 & Lochmias nematura & Potaro-Siparuni & YES & YES \\
\hline 0626 & LSUMZ_B38369 & Philydor rufum & Santa Cruz & YES & YES \\
\hline 0627 & LSUMZ_B81957 & Philydor rufum & San Jose & YES & YES \\
\hline
\end{tabular}




\begin{tabular}{|c|c|c|c|c|c|}
\hline $\begin{array}{l}\text { Internal } \\
\text { number }\end{array}$ & $\begin{array}{c}\text { number/field } \\
\text { number }\end{array}$ & Taxon & State & $\begin{array}{c}\text { UCEs } \\
\text { Sequences } \\
\end{array}$ & $\begin{array}{c}\text { ND2 } \\
\text { Sequences } \\
\end{array}$ \\
\hline 0628 & LSUMZ_B11885 & Philydor rufum & Esmeraldas & YES & YES \\
\hline 0629 & LSUMZ_B12127 & Philydor rufum & Pichincha & YES & YES \\
\hline 0630 & LSUMZ_B29942 & Philydor rufum & Imbabura & YES & YES \\
\hline 0631 & LSUMZ_B25966 & Philydor rufum & Caazapa & YES & YES \\
\hline 0632 & LSUMZ_B40199 & Philydor rufum & Loreto & YES & YES \\
\hline 0633 & LSUMZ_B89099 & Philydor rufum & Ucayali & YES & YES \\
\hline 0637 & LSUMZ_B22863 & Thamnophilus palliatus & $\mathrm{LaPaz}$ & YES & YES \\
\hline 0638 & LSUMZ_B38417 & Thamnophilus palliatus & Santa Cruz & YES & YES \\
\hline 0639 & LSUMZ_B46060 & Thamnophilus palliatus & San Martin & YES & YES \\
\hline 0640 & LSUMZ_B68260 & Thamnophilus palliatus & Beni & YES & YES \\
\hline 0641 & LSUMZ_B89121 & Thamnophilus palliatus & Ucayali & YES & YES \\
\hline 0642 & LSUMZ_B87886 & Thamnophilus ruficapillus & $\mathrm{LaPaz}$ & YES & YES \\
\hline 0643 & LSUMZ_B25944 & Xiphocolaptes albicollis & Caaguazu & YES & YES \\
\hline 0644 & LSUMZ_B25756 & Xiphocolaptes major & Alto Paraguay & YES & YES \\
\hline 0645 & LSUMZ_B38885 & Xiphocolaptes major & Santa Cruz & YES & YES \\
\hline 0646 & LSUMZ_B1874 & $\begin{array}{c}\text { Xiphocolaptes } \\
\text { promeropirhynchus }\end{array}$ & Pasco & YES & YES \\
\hline 0647 & LSUMZ_B4526 & $\begin{array}{c}\text { Xiphocolaptes } \\
\text { promeropirhynchus }\end{array}$ & Loreto & YES & YES \\
\hline 0648 & LSUMZ_B7774 & $\begin{array}{c}\text { Xiphocolaptes } \\
\text { promeropirhynchus }\end{array}$ & Pichincha & YES & YES \\
\hline 0649 & LSUMZ_B8795 & $\begin{array}{c}\text { Xiphocolaptes } \\
\text { promeropirhynchus }\end{array}$ & Toledo & YES & YES \\
\hline 0650 & LSUMZ_B32421 & $\begin{array}{c}\text { Xiphocolaptes } \\
\text { promeropirhynchus }\end{array}$ & Cajamarca & YES & YES \\
\hline 0651 & LSUMZ_B41765 & $\begin{array}{c}\text { Xiphocolaptes } \\
\text { promeropirhynchus }\end{array}$ & Cochabamba & YES & YES \\
\hline 0652 & LSUMZ_B44821 & $\begin{array}{c}\text { Xiphocolaptes } \\
\text { promeropirhynchus }\end{array}$ & Loreto & YES & YES \\
\hline 0653 & LSUMZ_B60983 & $\begin{array}{c}\text { Xiphocolaptes } \\
\text { promeropirhynchus }\end{array}$ & Francisco Morazan & YES & YES \\
\hline 0654 & LSUMZ_B66570 & $\begin{array}{c}\text { Xiphocolaptes } \\
\text { promeropirhynchus }\end{array}$ & Tumbes & YES & YES \\
\hline 0655 & LSUMZ_B87638 & $\begin{array}{c}\text { Xiphocolaptes } \\
\text { promeropirhynchus }\end{array}$ & Cochabamba & YES & YES \\
\hline 0656 & LSUMZ_B89012 & $\begin{array}{c}\text { Xiphocolaptes } \\
\text { promeropirhynchus }\end{array}$ & Ucayali & YES & YES \\
\hline 0657 & LSUMZ_B103529 & $\begin{array}{c}\text { Xiphocolaptes } \\
\text { promeropirhynchus }\end{array}$ & Loreto & YES & YES \\
\hline 0659 & MZ_81269 & $\begin{array}{c}\text { Thamnophilus aethiops } \\
\text { incertus }\end{array}$ & Maranhão & YES & YES \\
\hline 0660 & MZ_93741 & $\begin{array}{c}\text { Thamnophilus aethiops } \\
\text { polionotus }\end{array}$ & Roraima & YES & YES \\
\hline 0661 & J_1799 & $\begin{array}{c}\text { Thamnophilus aethiops } \\
\text { injunctus }\end{array}$ & Rondônia & YES & YES \\
\hline 0662 & LSU_58402 & Thamnophilus aroyae & Puno & YES & YES \\
\hline 0663 & H_2314 & Thamnophilus unicolor & Huila & YES & YES \\
\hline 0664 & $\begin{array}{c}\text { USNM_625181_C } \\
\text { MM 981 }\end{array}$ & Dysithamnus mentalis & $\begin{array}{c}\text { Upper Takutu-Upper } \\
\text { Essequibo }\end{array}$ & YES & YES \\
\hline
\end{tabular}




\begin{tabular}{|c|c|c|c|c|c|}
\hline $\begin{array}{l}\text { Internal } \\
\text { number }\end{array}$ & $\begin{array}{c}\text { number/field } \\
\text { number }\end{array}$ & Taxon & State & $\begin{array}{c}\text { UCEs } \\
\text { Sequences }\end{array}$ & $\begin{array}{c}\text { ND2 } \\
\text { Sequences }\end{array}$ \\
\hline 0665 & $\begin{array}{c}\text { USNM_635781_C } \\
\text { MM_3056 }\end{array}$ & Lochmias nematura & Maldonado & YES & YES \\
\hline 0668 & $\begin{array}{c}\text { USNM_630526_CA } \\
\text { G_773 }\end{array}$ & $\begin{array}{c}\text { Thamnophilus ruficapillus } \\
\text { ruficapillus }\end{array}$ & Colonia & YES & YES \\
\hline 0669 & $\begin{array}{c}\text { USNM_637091_C } \\
\text { MM_3391 }\end{array}$ & $\begin{array}{c}\text { Xiphocolaptes } \\
\text { promeropirhynchus }\end{array}$ & $\begin{array}{l}\text { Upper Takutu-Upper } \\
\text { Essequibo }\end{array}$ & YES & YES \\
\hline 0670 & USNM_586354 & $\begin{array}{c}\text { Xiphocolaptes } \\
\text { promeropirhynchus }\end{array}$ & Barima-Waini & YES & YES \\
\hline 0671 & LSU_58381 & Thamnophilus palliatus & Puno & YES & YES \\
\hline 0672 & LSU_58414 & Thamnophilus palliatus & Puno & YES & YES \\
\hline 0673 & LSU_31651 & Thamnophilus ruficapillus & SantaCruz & YES & YES \\
\hline 0674 & LSU_14842 & Thamnophilus torquatus & SantaCruz & YES & YES \\
\hline 0675 & YPM_148411 & $\begin{array}{c}\text { Thamnophilus ruficapillus } \\
\text { ruficapillus }\end{array}$ & Cerro Largo & YES & YES \\
\hline 0685 & LSU_6111 & Dysithamnus leucostictus & Morona-Santiago & YES & YES \\
\hline 0686 & LSU_10637 & Ancistrops strigilatus & Ucayali & YES & YES \\
\hline 0687 & AMNH_12102 & Phleocryptes melanops & Buenos Aires & YES & YES \\
\hline 0688 & LSUMZ_39987 & Platyrinchus mystaceus & Loreto & YES & YES \\
\hline 0691 & LSUMZ_35598 & Xiphorhynchus ocellatus & Pará & YES & YES \\
\hline 0692 & LSU_25854 & Philydor atricapillus & Caazapa & YES & YES \\
\hline 0693 & LSU_6965 & Philydor erythrocercum & Loreto & YES & YES \\
\hline 0694 & LSU_2250 & Philydor fuscipenne & Darien & YES & YES \\
\hline 0695 & LSU_10571 & Philydor erythropterum & Ucayali & YES & YES \\
\hline 0696 & LSU_10585 & Philydor pyrrhodes & Ucayali & YES & YES \\
\hline 0697 & LSUMZ_178807 & Thamnophilus doliatus & Veraguas & YES & YES \\
\hline 0698 & IAvH_12330 & Thamnophilus multistriatus & Valle & YES & YES \\
\hline 0699 & LSUMZ_183135 & Thamnophilus zarumae & Tumbes & YES & YES \\
\hline 0700 & MZ_94442 & $\begin{array}{c}\text { Platyrinchus mystaceus } \\
\text { cancromus }\end{array}$ & Minas Gerais & YES & YES \\
\hline 0701 & MZ_92167 & Platyrinchus mystaceus & São Paulo & YES & YES \\
\hline 0702 & MZ_92484 & Platyrinchus mystaceus & São Paulo & YES & YES \\
\hline 0703 & MZ_92485 & Platyrinchus mystaceus & São Paulo & YES & YES \\
\hline 0704 & MZ_93536 & Platyrinchus mystaceus & São Paulo & YES & YES \\
\hline 0705 & MZ_99454 & Platyrinchus mystaceus & Alagoas & YES & YES \\
\hline 0706 & MZ_99412 & Platyrinchus mystaceus & Alagoas & YES & YES \\
\hline 0707 & LSUMZ_B5542 & $\begin{array}{c}\text { Platyrinchus mystaceus } \\
\text { zamorae } \\
\end{array}$ & San Martin & YES & YES \\
\hline 0708 & LSUMZ_B5970 & $\begin{array}{c}\text { Platyrinchus mystaceus } \\
\text { zamorae }\end{array}$ & Morona-Santiago & YES & YES \\
\hline 0709 & LSUMZ_B7434 & Platyrinchus mystaceus duidae & Amazonas & YES & YES \\
\hline 0710 & LSUMZ_B7616 & $\begin{array}{c}\text { Platyrinchus mystaceus } \\
\text { bifasciatus }\end{array}$ & Beni & YES & YES \\
\hline 0711 & LSUMZ_B11966 & $\begin{array}{c}\text { Platyrinchus mystaceus } \\
\text { albogularis }\end{array}$ & Esmeraldas & YES & YES \\
\hline 0712 & LSUMZ_B16047 & $\begin{array}{c}\text { Platyrinchus mystaceus } \\
\text { neglectus }\end{array}$ & Heredia & YES & YES \\
\hline
\end{tabular}




\begin{tabular}{|c|c|c|c|c|c|}
\hline $\begin{array}{l}\text { Internal } \\
\text { number }\end{array}$ & $\begin{array}{c}\text { number/field } \\
\text { number }\end{array}$ & Taxon & State & $\begin{array}{c}\text { UCEs } \\
\text { Sequences }\end{array}$ & $\begin{array}{c}\text { ND2 } \\
\text { Sequences }\end{array}$ \\
\hline 0713 & LSUMZ_B22637 & $\begin{array}{c}\text { Platyrinchus mystaceus } \\
\text { partridgei }\end{array}$ & $\mathrm{LaPaz}$ & YES & YES \\
\hline 0714 & LSUMZ_B26448 & $\begin{array}{c}\text { Platyrinchus mystaceus } \\
\text { neglectus }\end{array}$ & Chiriqui & YES & YES \\
\hline 0715 & LSUMZ_B27767 & $\begin{array}{c}\text { Platyrinchus mystaceus } \\
\text { zamorae }\end{array}$ & Loreto & YES & YES \\
\hline 0716 & LSUMZ_B32985 & Platyrinchus mystaceus & Cajamarca & YES & YES \\
\hline 0717 & LSUMZ_B35967 & $\begin{array}{c}\text { Platyrinchus mystaceus } \\
\text { insularis }\end{array}$ & Caroni & YES & YES \\
\hline 0718 & LSUMZ_B39987 & Platyrinchus mystaceus & Loreto & & YES \\
\hline 0719 & L_28375 & Platyrinchus mystaceus & Panama District & YES & YES \\
\hline 0720 & USNM_607842 & Platyrinchus cancrominus & Bocas del Toro & YES & YES \\
\hline 0721 & L_55356 & Platyrinchus saturatus & Sipaliwini & YES & YES \\
\hline 0722 & USNM_625250 & Platyrinchus platyrhynchos & $\begin{array}{c}\text { Upper Takutu-Upper } \\
\text { Essequibo } \\
\end{array}$ & YES & YES \\
\hline 0723 & LSUMZ_33080 & Platyrinchus flavigularis & Cajamarca & YES & YES \\
\hline 0724 & KU_88454 & Platyrinchus leucoryphus & Caazapa & YES & YES \\
\hline 0725 & L_11136 & Platyrinchus coronatus & Ucayali & YES & YES \\
\hline 0726 & MPEG_79461 & $\begin{array}{c}\text { Platyrinchus mystaceus } \\
\text { cancromus }\end{array}$ & Tocantins & YES & YES \\
\hline 0727 & FMNH_399223 & Thamnophilus aethiops & Alagoas & & YES \\
\hline 0728 & MPEG_62216 & Thamnophilus aethiops & Amazonas & & YES \\
\hline
\end{tabular}

Table S2. Samples of ND2 gene for all species analyzed.

\begin{tabular}{|c|c|c|}
\hline Species & Number ND2 samples & Outgroup \\
\hline Dysithamnus mentalis & 135 & D. leucostictus \\
\hline Lochmias nematura & 26 & Phleocryptes melanops \\
\hline Philydor rufum & 23 & P. erythropterum/P. atricapillus \\
\hline Platyrinchus mystaceus & 136 & P. flavigularis/P. leucoryphus \\
\hline Thamnophilus caerulescens & 53 & Thamnophilus aethiops \\
\hline T. palliatus/tenuepunctatus complex & $26 / 2$ & Thamnophilus zarumae \\
\hline T. ruficapillus/torquatus complex & $13 / 12$ & Thamnophilus doliatus \\
\hline Xiphocolaptes complex & 68 & Xiphorhynchus ocellatus \\
\hline
\end{tabular}


Table S3. Nucleotide diversity all species.

\begin{tabular}{|c|c|c|}
\hline Species & Nucleotide Diversity & Variance \\
\hline Dysithamnus mentalis & 0.00869463 & $1.99 \mathrm{E}-05$ \\
\hline Lochmias nematura & 0.031939979 & 0.000256931 \\
\hline Platyrinchus mystaceus & 0.023392946 & 0.000131059 \\
\hline Philydor rufum & 0.012618761 & $4.32 \mathrm{E}-05$ \\
\hline Thamnophilus caerulescens & 0.012732651 & $4.17 \mathrm{E}-05$ \\
\hline Thamnophilus palliatus/tenuepunctatus complex & 0.006864306 & $1.36 \mathrm{E}-05$ \\
\hline Thamnophilus ruficapillus/torquatus complex & 0.023857934 & 0.000145938 \\
\hline Xiphocolaptes complex & 0.020094585 & $9.91 \mathrm{E}-05$ \\
\hline
\end{tabular}

Table S4. D' Tajima test for all species.

\begin{tabular}{|c|c|c|c|}
\hline Species & D' Tajima & Pval_normal & Pval_beta \\
\hline Dysithamnus mentalis & -2.251003653 & 0.024385306 & 0.005592793 \\
\hline Lochmias nematura & -0.620660997 & 0.534822697 & 0.575138869 \\
\hline Platyrinchus mystaceus & -3.045099416 & 0.002326034 & $2.93 \mathrm{E}-12$ \\
\hline Philydor rufum & -3.383077795 & 0.000716783 & 0 \\
\hline Thamnophilus caerulescens & -2.9958257 & 0.002737028 & $9.17 \mathrm{E}-11$ \\
\hline Thamnophilus palliatus/tenuepunctatus complex & -2.413419957 & 0.015803599 & 0.001768009 \\
\hline Thamnophilus ruficapillus/torquatus complex & -0.157467034 & 0.874876787 & 0.910419562 \\
\hline Xiphocolaptes complex & -2.268353921 & 0.023307644 & 0.005799934 \\
\hline
\end{tabular}


Table S5. AMOVA values for all species.

\begin{tabular}{|c|c|c|c|c|}
\hline Species & $\begin{array}{c}\text { Variations } \\
\text { between groups }\end{array}$ & $\begin{array}{c}\text { Variations between } \\
\text { samples within groups }\end{array}$ & $\begin{array}{c}\text { Variations within } \\
\text { samples }\end{array}$ & $\begin{array}{c}\text { Total } \\
\text { variations }\end{array}$ \\
\hline Dysithamnus mentalis & 34.76625693 & 43.54157179 & 21.69217128 & 100 \\
\hline Lochmias nematura & 51.70021181 & 20.68458654 & 27.61520165 & 100 \\
\hline Platyrinchus mystaceus & 67.69385985 & 27.05626627 & 5.249873881 & 100 \\
\hline Philydor rufum & 62.52351139 & 31.9792931 & 5.497195517 & 100 \\
\hline $\begin{array}{c}\text { Thamnophilus } \\
\text { caerulescens }\end{array}$ & 43.20605233 & 34.08672707 & 22.70722059 & 100 \\
\hline $\begin{array}{c}\text { T. palliatus/tenuepunctatus } \\
\text { complex }\end{array}$ & 33.82054327 & 38.80766396 & 27.37179277 & 100 \\
\hline $\begin{array}{c}\text { T. ruficapillus/torquatus } \\
\text { complex }\end{array}$ & 14.67363551 & 21.94052388 & 63.38584061 & 100 \\
\hline Xiphocolaptes complex & 53.34949299 & 23.51860245 & 23.13190457 & 100 \\
\hline
\end{tabular}

Table S6. Watterson test for all species.

\begin{tabular}{|c|c|c|}
\hline Species & Theta & Variance \\
\hline Dysithamnus mentalis & 27.0873717 & 42.85078595 \\
\hline Lochmias nematura & 35.37774622 & 132.6569364 \\
\hline Platyrinchus mystaceus & 123.370606 & 810.7423874 \\
\hline Philydor rufum & 38.20296245 & 162.7101482 \\
\hline Thamnophilus caerulescens & 61.74187531 & 293.7406216 \\
\hline Thamnophilus palliatus/tenuepunctatus complex & 13.61957831 & 20.97534304 \\
\hline Thamnophilus ruficapillus/torquatus complex & 25.4240104 & 71.42068774 \\
\hline Xiphocolaptes complex & 52.19912396 & 190.966409 \\
\hline
\end{tabular}

Table S7. Nucleotide diversity of populations of $D$. mentalis.

\begin{tabular}{|c|c|c|}
\hline Groups/D. mentalis & Nucleotide diversity & Variance \\
\hline affinis & 0.003418803 & $4.3574 \mathrm{E}-06$ \\
\hline mentalis & 0.007060315 & 0.000014104 \\
\hline Andes & 0.006964809 & $1.36037 \mathrm{E}-05$ \\
\hline Northern Brazil & 0.004392126 & $6.0192 \mathrm{E}-06$ \\
\hline
\end{tabular}


Table S8. Fst values for the populations of D. mentalis.

\begin{tabular}{|c|c|c|c|c|}
\hline fst - Groups/D. mentalis & Northern Brazil & mentalis & affinis & Andes \\
\hline Northern Brazil & 0 & 0.28071366 & 0.208782539 & 0.186198921 \\
\hline mentalis & 0.28071366 & 0 & 0.259570255 & 0.262508232 \\
\hline affinis & 0.208782539 & 0.259570255 & 0 & 0.109405627 \\
\hline Andes & 0.186198921 & 0.262508232 & 0.109405627 & 0 \\
\hline
\end{tabular}

Table S9. Nucleotide diversity of populations of L. nematura.

\begin{tabular}{|c|c|c|}
\hline Groups/L. nematura & Nucleotide diversity & Variance \\
\hline Atlantic Forest & 0.005226719 & 0.00000915 \\
\hline Central Andes & 0.032928693 & 0.000308371 \\
\hline Tepuis & 0.000970874 & 0.00000188 \\
\hline
\end{tabular}

Table S10. Fst values for the populations of L. nematura.

\begin{tabular}{|c|c|c|c|}
\hline fst - Groups/L. nematura & Atlantic Forest & Central Andes & Tepuis \\
\hline Atlantic Forest & 0 & 0.47698182 & 0.276255343 \\
\hline Central Andes & 0.47698182 & 0 & 0.255304392 \\
\hline Tepuis & 0.276255343 & 0.255304392 & 0 \\
\hline
\end{tabular}

Table S11. Nucleotide diversity of populations of $P$. mystaceus.

\begin{tabular}{|c|c|c|}
\hline Groups/P. mystaceus & Nucleotide diversity & Variance \\
\hline Andes & 0.032865845 & 0.000296936 \\
\hline Atlantic Forest & 0.01040153 & 0.000028 \\
\hline niveigularis & 0.003384841 & 0.0000039 \\
\hline
\end{tabular}


Table S12. Fst values for the populations of $P$. mystaceus.

\begin{tabular}{|c|c|c|c|}
\hline fst - Groups/P. mystaceus & niveigularis & Atlantic Forest & Andes \\
\hline niveigularis & 0 & 0.577715915 & 0.510731188 \\
\hline Atlantic Forest & 0.577715915 & 0 & 0.253501627 \\
\hline Andes & 0.510731188 & 0.253501627 & 0 \\
\hline
\end{tabular}

Table S13. Nucleotide diversity of populations of $P$. rufum.

\begin{tabular}{|c|c|c|}
\hline Groups/P. rufum & Nucleotide diversity & Variance \\
\hline Atlantic Forest & 0.001905654 & $1.69 \mathrm{E}-06$ \\
\hline Andes & 0.012045925 & $4.42 \mathrm{E}-05$ \\
\hline
\end{tabular}

Table S14. Fst values for the populations of $P$. rufum.

\begin{tabular}{|c|c|c|}
\hline fst - Groups/P. rufum & Atlantic Forest & Andes \\
\hline Atlantic Forest & 0 & 0.510964386 \\
\hline Andes & 0.510964386 & 0 \\
\hline
\end{tabular}

Table S15. Nucleotide diversity of populations of T. caerulescens.

\begin{tabular}{|c|c|c|}
\hline Groups/T. caerulescens & Nucleotide diversity & Variance \\
\hline Andean & 0.013748868 & 0.0000558 \\
\hline caerulescens & 0.005067237 & 0.00000782 \\
\hline cearensis & 0.001976422 & 0.00000198 \\
\hline
\end{tabular}

Table S16. Fst values for the populations of T. caerulescens.

\begin{tabular}{|c|c|c|c|}
\hline fst - Groups/T. caerulescens & cearensis & caerulescens & Andean \\
\hline cearensis & 0 & 0.538138706 & 0.423313568 \\
\hline caerulescens & 0.538138706 & 0 & 0.229798545 \\
\hline Andean & 0.423313568 & 0.229798545 & 0 \\
\hline
\end{tabular}


Table S17. Nucleotide diversity of populations of T. palliatus-tenuepunctatus complex.

\begin{tabular}{|c|c|c|}
\hline Groups/T.palliatus-tenuepunctatus & Nucleotide diversity & Variance \\
\hline Atlantic Forest $(\boldsymbol{T}$. . vestitus $)$ & 0.000455996 & 0.000000274 \\
\hline Central Andes $\boldsymbol{( T . p . p u n c t i c e p s )}$ & 0.005723577 & 0.0000135 \\
\hline Northern Andes & 0.007284553 & 0.000021 \\
\hline palliatus & 0.004054054 & 0.00000617 \\
\hline
\end{tabular}

Table S18. Fst values for the populations of T. palliatus-tenuepunctatus complex.

\begin{tabular}{|c|c|c|c|c|}
\hline $\begin{array}{c}\text { fst - Groups/T. palliatus- } \\
\text { tenuepunctatus }\end{array}$ & $\begin{array}{c}\text { Northern } \\
\text { Andes }\end{array}$ & $\begin{array}{c}\text { Atlantic Forest (T. } \boldsymbol{p} \text {. } \\
\text { vestitus) }\end{array}$ & palliatus & $\begin{array}{c}\text { Central Andes (T. } \boldsymbol{p} \text {. } \\
\text { vestitus) }\end{array}$ \\
\hline Northern Andes & 0 & 0.333535855 & $\begin{array}{c}0.175842 \\
82\end{array}$ & 0.374625835 \\
\hline Atlantic Forest (T. p. vestitus) & 0.333535855 & 0 & $\begin{array}{c}0.117723 \\
638\end{array}$ & $\mathbf{0 . 5 8 4 4 9 0 4 0 5}$ \\
\hline palliatus & 0.17584282 & 0.117723638 & 0 & 0.425881627 \\
\hline $\begin{array}{c}\text { Central Andes (T. } \boldsymbol{p} \text {. } \\
\text { puncticeps) }\end{array}$ & 0.374625835 & $\mathbf{0 . 5 8 4 4 9 0 4 0 5}$ & $\begin{array}{c}0.425881 \\
627\end{array}$ & 0 \\
\hline
\end{tabular}

Table S19. Nucleotide diversity of populations of T. ruficapillus-torquatus complex.

\begin{tabular}{|c|c|c|}
\hline Groups/T. ruficapillus-torquatus & Nucleotide diversity & Variance \\
\hline Northern Atlantic Forest & 0.027636364 & 0.00021892 \\
\hline Southern Atlantic Forest & 0.005774783 & 0.0000137 \\
\hline Central Andes & 0.021707317 & 0.000149177 \\
\hline
\end{tabular}


Table S20. Fst values for the populations of T. ruficapillus-torquatus complex.

\begin{tabular}{|c|c|c|c|}
\hline $\begin{array}{c}\text { fst - Groups/T. ruficapillus- } \\
\text { torquatus }\end{array}$ & $\begin{array}{c}\text { Central } \\
\text { Andes }\end{array}$ & $\begin{array}{c}\text { Southern Atlantic } \\
\text { Forest }\end{array}$ & $\begin{array}{c}\text { Northern Atlantic } \\
\text { Forest }\end{array}$ \\
\hline Central Andes & 0 & 0.221523446 & 0.08710577 \\
\hline Southern Atlantic Forest & 0.221523446 & 0 & 0.258282196 \\
\hline Northern Atlantic Forest & 0.08710577 & 0.258282196 & 0 \\
\hline
\end{tabular}

Table S21. Nucleotide diversity of populations of Xiphocolaptes complex.

\begin{tabular}{|c|c|c|}
\hline Groups/Xiphocolaptes complex & Nucleotide diversity & Variance \\
\hline Amazonian $(\boldsymbol{X}$. p. orenocensis) & 0.007103464 & 0.0000148 \\
\hline Andes (highlands) & 0.010997632 & 0.0000335 \\
\hline Atlantic Forest (X. albicollis) & 0.002405396 & 0.00000242 \\
\hline Caatinga (X. falcirostris) & 0.000768492 & 0.000000586 \\
\hline Tepuis + Central America & 0.009450338 & 0.000034 \\
\hline
\end{tabular}

Table S22. Fst values for the populations of Xiphocolaptes complex.

\begin{tabular}{|c|c|c|c|c|c|}
\hline $\begin{array}{c}\text { fst }- \\
\text { Groups/Xiphocolaptes } \\
\text { complex }\end{array}$ & $\begin{array}{c}\text { Atlantic Forest } \\
(\boldsymbol{X} \text {. albicollis) }\end{array}$ & $\begin{array}{c}\text { Amazonian }(\boldsymbol{X} . \boldsymbol{p} . \\
\text { orenocensis })\end{array}$ & $\begin{array}{c}\text { Andes } \\
\text { (highlands) }\end{array}$ & $\begin{array}{c}\text { Tepuis + } \\
\text { Central } \\
\text { America }\end{array}$ & $\begin{array}{c}\text { Caatinga }(\boldsymbol{X} . \\
\text { falcirostris })\end{array}$ \\
\hline $\begin{array}{c}\text { Atlantic Forest }(\boldsymbol{X} . \\
\text { albicollis) }\end{array}$ & 0 & 0.672407001 & 0.488897976 & 0.667094017 & 0.864127982 \\
\hline $\begin{array}{c}\text { Amazonian } \boldsymbol{( X .} \boldsymbol{p} . \\
\text { orenocensis) }\end{array}$ & 0.672407001 & 0 & 0.480218347 & 0.380000248 & 0.580884235 \\
\hline Andes (highlands) & 0.488897976 & 0.480218347 & 0 & 0.255366951 & 0.4195593 \\
\hline $\begin{array}{c}\text { Tepuis + Central } \\
\text { America }\end{array}$ & 0.667094017 & 0.380000248 & 0.255366951 & 0 & 0.703045975 \\
\hline $\begin{array}{c}\text { Caatinga }(\boldsymbol{X} . \\
\text { falcirostris })\end{array}$ & 0.864127982 & 0.580884235 & 0.4195593 & 0.703045975 & 0 \\
\hline
\end{tabular}


Table S23. Cross-entropy values for D. mentalis $(\boldsymbol{\alpha}=1,10,50,100,500,1000)$.

\begin{tabular}{|c|c|c|c|c|c|c|c|c|c|c|c|c|c|}
\hline Alpha $=1$ & $\mathrm{~K}=1$ & $K=2$ & $\mathrm{~K}=\mathbf{3}$ & $K=4$ & $K=5$ & $K=6$ & $\mathrm{~K}=7$ & $K=8$ & $\mathrm{~K}=9$ & $K=10$ & lowest & 2d. lowest & Difference \\
\hline $\min$ & 0.32819 & 0.30028 & 0.29311 & 0.28945 & 0.29359 & 0.30219 & 0.30352 & 0.31382 & 0.31463 & 0.33262 & 0.28945 & 0.29311 & 0.00365 \\
\hline mean & 0.35265 & 0.32493 & 0.31938 & 0.31803 & 0.32229 & 0.32807 & 0.33356 & 0.34061 & 0.34734 & 0.35557 & 0.31803 & 0.31938 & 0.00135 \\
\hline $\max$ & 0.38116 & 0.34961 & 0.34756 & 0.34027 & 0.34762 & 0.35868 & 0.36573 & 0.37150 & 0.38269 & 0.39560 & & & \\
\hline Alpha $=10$ & $\mathrm{~K}=1$ & $\mathrm{~K}=2$ & $\mathbf{K}=\mathbf{3}$ & $K=4$ & $K=5$ & $K=6$ & $\mathrm{~K}=7$ & $K=8$ & $K=9$ & $K=10$ & lowest & 2d. lowest & Difference \\
\hline $\min$ & 0.32956 & 0.30167 & 0.29540 & 0.29131 & 0.29841 & 0.30421 & 0.30558 & 0.31345 & 0.32293 & 0.32694 & 0.29131 & 0.29540 & 0.00410 \\
\hline mean & 0.35537 & 0.32758 & 0.32189 & 0.32119 & 0.32558 & 0.33108 & 0.33663 & 0.34414 & 0.35163 & 0.35897 & 0.32119 & 0.32189 & 0.00071 \\
\hline $\max$ & 0.37523 & 0.34639 & 0.34331 & 0.34755 & 0.35264 & 0.35410 & 0.37069 & 0.37017 & 0.37785 & 0.38424 & & & 0.00308 \\
\hline Alpha $=50$ & $\mathrm{~K}=1$ & $K=2$ & $K=3$ & $K=4$ & $K=5$ & $K=6$ & $K=7$ & $K=8$ & $K=9$ & $K=10$ & lowest & 2d. lowest & Difference \\
\hline $\min$ & 0.32465 & 0.29819 & 0.29250 & 0.28969 & 0.29700 & 0.29708 & 0.30786 & 0.31099 & 0.32365 & 0.32405 & 0.28969 & 0.29250 & 0.00281 \\
\hline mean & 0.35385 & 0.32599 & 0.32034 & 0.31986 & 0.32394 & 0.32970 & 0.33658 & 0.34437 & 0.35298 & 0.36065 & 0.31986 & 034 & 0.00048 \\
\hline $\max$ & 0.38727 & 0.36026 & 0.36137 & 0.35683 & 0.35866 & 0.36559 & 0.36770 & 0.38910 & 0.39455 & 0.39349 & 0.35683 & 0.35866 & 0.00183 \\
\hline Alpha $=100$ & $K=1$ & $K=2$ & $\mathbf{K}=\mathbf{3}$ & $K=4$ & $K=5$ & $K=6$ & $K=7$ & $K=8$ & $K=9$ & $K=10$ & lowest & 2d. lowest & Difference \\
\hline $\min$ & 0.32414 & 0.29326 & 0.28900 & 0.28704 & 0.28995 & 0.29752 & 0.30972 & 0.31400 & 0.32447 & 0.32914 & 0.28704 & 0.28900 & 0.00196 \\
\hline mean & 0.35298 & 0.32518 & 0.31965 & 0.31890 & 0.32444 & 0.33036 & 0.33944 & 0.34641 & 0.35376 & 0.36420 & 0.31890 & & 0.00074 \\
\hline $\max$ & 0.37519 & 0.34766 & 0.34597 & 0.34249 & 0.34764 & 0.36089 & 0.36607 & 0.37134 & 0.38263 & 0.39334 & & & \\
\hline Alpha $=500$ & $\mathrm{~K}=1$ & $K=2$ & $K=3$ & $K=4$ & $K=5$ & $K=6$ & $K=7$ & $K=8$ & $\mathrm{~K}=9$ & $K=10$ & lowest & 2d. lowest & Difference \\
\hline $\min$ & 0.31913 & 0.29234 & 0.29297 & 0.28644 & 0.28949 & 0.30357 & 0.30913 & 0.31466 & 0.33568 & 0.33667 & 0.28644 & 0.28949 & 0.00305 \\
\hline mean & 0.35284 & 0.32592 & 0.32475 & 0.32428 & 0.33154 & 0.34014 & 0.35030 & 0.36028 & 0.37206 & 0.38411 & 0.32428 & 0.32475 & 0.00047 \\
\hline $\max$ & 0.39593 & 0.36736 & 0.36236 & 0.37350 & 0.37060 & 0.38341 & 0.39135 & 0.40364 & 0.42117 & 0.43984 & 0.36236 & 0.36736 & 0.00500 \\
\hline Alpha $=1000$ & $\mathrm{~K}=1$ & $K=2$ & $K=3$ & $K=4$ & $K=5$ & $K=6$ & $\mathrm{~K}=7$ & $K=8$ & $K=9$ & $K=10$ & & 2d. lowest & Difference \\
\hline $\min$ & 0.32370 & 0.29830 & 0.29160 & 0.29250 & 0.30225 & 0.30658 & 0.31613 & 0.33990 & 0.34588 & 0.35339 & 0.29160 & 0.29250 & 0.00090 \\
\hline mean & 0.35325 & 0.32749 & 0.32929 & 0.32995 & 0.33873 & 0.34953 & 0.36085 & 0.37407 & 0.38759 & 0.40072 & 0.32749 & 0.32929 & 0.00180 \\
\hline $\max$ & 0.38054 & 0.35459 & 0.35662 & 0.36867 & 0.37101 & 0.38151 & 0.40102 & 0.40207 & 0.42617 & 0.44522 & 0.35459 & 0.35662 & 0.00202 \\
\hline
\end{tabular}


Table S24. Cross-entropy values for $T$. caerulescens $(\boldsymbol{\alpha}=1,10,50,100,500,1000)$.

\begin{tabular}{|c|c|c|c|c|c|c|c|c|c|c|c|c|c|c|c|}
\hline Alpha $=1$ & $K=1$ & $K=2$ & $K=3$ & $K=4$ & $K=5$ & $K=6$ & $K=7$ & $K=8$ & $K=9$ & $K=10$ & $K=11$ & $K=12$ & lowest & 2d. lowest & Difference \\
\hline $\min$ & 0.41463 & 0.37810 & 0.37439 & 0.38679 & 0.40498 & 0.40998 & 0.42651 & 0.43924 & 0.46538 & 0.46480 & 0.488458 & 0.5041613 & 0.37439 & 0.37810 & 0.00370 \\
\hline mean & 0.46818 & 0.43040 & 0.42527 & 0.43747 & 0.45027 & 0.46680 & 0.48686 & 0.50796 & 0.52824 & 0.54831 & 0.5722283 & 0.5980912 & 0.42527 & 0.43040 & 0.00513 \\
\hline $\max$ & 0.51230 & 0.47448 & 0.47385 & 0.49359 & 0.50404 & 0.52809 & 0.56818 & 0.57198 & 0.62220 & 0.63828 & 0.660845 & 0.6886311 & 0.47385 & 0.47448 & 0.00063 \\
\hline Alpha $=10$ & $K=1$ & $K=2$ & $K=3$ & $K=4$ & $K=5$ & $K=6$ & $K=7$ & $K=8$ & $K=9$ & $K=10$ & $K=11$ & $K=12$ & lowest & 2d. lowest & Difference \\
\hline $\min$ & 0.42668 & 0.38206 & 0.37474 & 0.39066 & 0.38981 & 0.41915 & 0.41590 & 0.43532 & 0.45610 & 0.49724 & 0.5225096 & 0.5146925 & 0.37474 & 0.38206 & 0.00732 \\
\hline mean & 0.46730 & 0.42947 & 0.42333 & 0.43588 & 0.44978 & 0.46952 & 0.48733 & 0.50797 & 0.53013 & 0.54987 & 0.5744045 & 0.5983819 & 0.42333 & 0.42947 & 0.00614 \\
\hline $\max$ & 0.51302 & 0.47696 & 0.50495 & 0.50696 & 0.51499 & 0.53598 & 0.53778 & 0.57670 & 0.62257 & 0.63576 & 0.7052284 & 0.6887136 & 0.47696 & 0.50495 & 0.02799 \\
\hline Alpha $=50$ & $K=1$ & $\mathrm{~K}=2$ & $K=3$ & $K=4$ & $K=5$ & $K=6$ & $K=7$ & $K=8$ & $K=9$ & $K=10$ & $K=11$ & $K=12$ & lowest & 2d. lowest & Difference \\
\hline $\min$ & 0.42023 & 0.38590 & 0.37785 & 0.38267 & 0.38716 & 0.42027 & 0.41344 & 0.45151 & 0.46307 & 0.49679 & 0.4992932 & 0.5330865 & 0.37785 & 0.38267 & 0.00482 \\
\hline mean & 0.46999 & 0.43371 & 0.42788 & 0.44203 & 0.45580 & 0.47623 & 0.49685 & 0.51848 & 0.53777 & 0.56201 & 0.5846736 & 0.6082007 & 0.42788 & 0.43371 & 0.00583 \\
\hline $\max$ & 0.51047 & 0.46892 & 0.49179 & 0.49246 & 0.52463 & 0.53898 & 0.54475 & 0.59322 & 0.59113 & 0.65335 & 0.6883291 & 0.7150304 & 0.46892 & 0.49179 & 0.02287 \\
\hline Alpha $=100$ & $K=1$ & $K=2$ & $K=3$ & $K=4$ & $K=5$ & $K=6$ & $K=7$ & $K=8$ & $K=9$ & $K=10$ & $K=11$ & $K=12$ & lowest & 2d. lowest & Difference \\
\hline $\min$ & 0.41976 & 0.38379 & 0.37935 & 0.38487 & 0.39180 & 0.40879 & 0.43221 & 0.46163 & 0.48039 & 0.49214 & 0.5288857 & 0.5362145 & 0.37935 & 0.38379 & 0.00443 \\
\hline mean & 0.46993 & 0.43360 & 0.42808 & 0.44140 & 0.45668 & 0.47602 & 0.49718 & 0.52316 & 0.53976 & 0.56591 & 0.5922528 & 0.6147111 & 0.42808 & 0.43360 & 0.00552 \\
\hline $\max$ & 0.51528 & 0.48304 & 0.48267 & 0.50933 & 0.50896 & 0.54028 & 0.55194 & 0.59271 & 0.62097 & 0.65933 & 0.7248343 & 0.6998336 & 0.48267 & 0.48304 & 0.00037 \\
\hline Alpha $=500$ & $K=1$ & $K=2$ & $K=3$ & $K=4$ & $K=5$ & $K=6$ & $K=7$ & $K=8$ & $K=9$ & $K=10$ & $K=11$ & $K=12$ & lowest & 2d. lowest & Difference \\
\hline $\min$ & 0.41880 & 0.38092 & 0.38137 & 0.39765 & 0.40557 & 0.44746 & 0.44972 & 0.50243 & 0.50964 & 0.53512 & 0.5661571 & 0.5901958 & 0.38092 & 0.38137 & 0.00045 \\
\hline mean & 0.46720 & 0.43245 & 0.43261 & 0.44980 & 0.47214 & 0.49230 & 0.52136 & 0.54960 & 0.57662 & 0.60627 & 0.6349305 & 0.6638951 & 0.43245 & 0.43261 & 0.00016 \\
\hline $\max$ & 0.53756 & 0.50182 & 0.50858 & 0.52420 & 0.54205 & 0.57109 & 0.62757 & 0.60047 & 0.65621 & 0.68353 & 0.7254975 & 0.7601563 & 0.50182 & 0.50858 & 0.00675 \\
\hline Alpha $=1000$ & $K=1$ & $K=2$ & $K=3$ & $K=4$ & $K=5$ & $K=6$ & $K=7$ & $K=8$ & $K=9$ & $K=10$ & $K=11$ & $K=12$ & lowest & 2d. lowest & Difference \\
\hline $\min$ & 0.43014 & 0.39367 & 0.39913 & 0.40786 & 0.43649 & 0.45183 & 0.48806 & 0.50107 & 0.50813 & 0.55429 & 0.5805905 & 0.596142 & 0.39367 & 0.39913 & 0.00546 \\
\hline mean & 0.46897 & 0.43501 & 0.43493 & 0.45501 & 0.47874 & 0.51062 & 0.53522 & 0.56459 & 0.59446 & 0.62411 & 0.6530534 & 0.6837274 & 0.43493 & 0.43501 & 0.00008 \\
\hline $\max$ & 0.52614 & 0.48990 & 0.48405 & 0.52469 & 0.54719 & 0.60167 & 0.60715 & 0.64636 & 0.66495 & 0.73103 & 0.7408487 & 0.7669721 & 0.48405 & 0.48990 & 0.00586 \\
\hline
\end{tabular}


Table S25. Cross-entropy values for T. palliatus/tenuepunctatus complex ( $\boldsymbol{\alpha}=1,10,50,100,500,1000)$.

\begin{tabular}{|c|c|c|c|c|c|c|c|c|c|c|c|c|c|}
\hline Alpha $=1$ & $K=1$ & $K=2$ & $\mathbf{K}=\mathbf{3}$ & $K=4$ & $K=5$ & $K=6$ & $K=7$ & $K=8$ & $K=9$ & $K=10$ & lowest & 2d. lowest & Difference \\
\hline $\min$ & 0.34895 & 0.33344 & 0.33610 & 0.33175 & 0.34725 & 0.34923 & 0.36967 & 0.39404 & 0.40350 & 0.42788 & 0.33175 & 0.33344 & 0.00169 \\
\hline mean & 0.39979 & 0.38348 & 0.38244 & 0.38363 & 0.39358 & 0.41104 & 0.42897 & 0.44658 & 0.46690 & & & & \\
\hline $\max$ & 0.46923 & 0.44864 & 0.44268 & 0.45043 & 0.46121 & & 0.48939 & 0.51920 & 0.55222 & 0.56433 & & & \\
\hline Alpha $=10$ & $\mathrm{~K}=1$ & $\mathrm{~K}=2$ & $\mathrm{~K}=\mathbf{3}$ & $K=4$ & $K=5$ & $K=6$ & $K=7$ & $K=8$ & $K=9$ & $K=10$ & lowest & 2d. lowest & Difference \\
\hline $\min$ & 0.34911 & 0.33645 & 0.33948 & 0.33458 & 0.34774 & 0.36080 & 0.38066 & 0.39031 & 0.41705 & 0.43733 & 0.33458 & 0.33645 & 0.00186 \\
\hline mean & 0.40088 & 0.38381 & 0.38356 & 0.38616 & 0.39666 & 0.41333 & 0.43294 & 0.45061 & 0.46812 & 0.48892 & 0.38356 & 0.38381 & 0.00025 \\
\hline $\max$ & 0.45002 & 0.42801 & 0.43283 & 0.43207 & 0.44712 & 0.47304 & 0.51356 & 0.51810 & 0.52441 & 0.55911 & & & \\
\hline Alpha $=50$ & $\mathrm{~K}=1$ & $K=2$ & $\mathbf{K}=\mathbf{3}$ & $K=4$ & $K=5$ & $K=6$ & $\mathrm{~K}=7$ & $K=8$ & & & & 2d. lowest & Difference \\
\hline $\min$ & 0.35037 & 0.33511 & 0.33255 & 0.33746 & 0.34944 & 0.35679 & 0.39422 & 0.39104 & 0.40386 & 0.44513 & 0.33 & & \\
\hline mean & 0.40163 & 0.38466 & 0.38509 & 0.38744 & 0.40167 & 0.41723 & 0.43627 & 0.45454 & 0.47645 & 0.49463 & 0.3 & 0.3 & 0.0 \\
\hline $\max$ & 0.45600 & 0.44169 & 0.44560 & 0.44520 & 0.47858 & 0.47270 & 0.50525 & 0.53611 & 0.54382 & 0.55767 & 0.44169 & 0.44520 & 0.00351 \\
\hline Alpha $=100$ & $\mathrm{~K}=1$ & $\mathrm{~K}=2$ & $\mathrm{~K}=\mathbf{3}$ & $K=4$ & $K=5$ & $K=6$ & $\mathrm{~K}=7$ & $K=8$ & $K=9$ & $K=10$ & lowest & 2d. lowest & Difference \\
\hline $\min$ & 0.34138 & 0.32672 & 0.32561 & 0.33214 & 0.34836 & 0.35298 & 0.38003 & 0.38453 & 0.40861 & 0.43222 & 0.32561 & 0.32672 & 0.001 \\
\hline mean & 0.39995 & 0.38330 & 0.38415 & 0.38862 & & 0.42361 & 0.43781 & & & & & & \\
\hline $\max$ & 0.44814 & 0.43570 & 0.45058 & 0.46120 & 0.47361 & 0.49105 & 0.50345 & 0.54608 & 0.54568 & 0.57023 & & & \\
\hline Alpha $=500$ & $\mathrm{~K}=1$ & $K=2$ & $\mathbf{K}=\mathbf{3}$ & $K=4$ & $K=5$ & $K=6$ & $\mathrm{~K}=7$ & $\mathrm{~K}=\mathbf{8}$ & $\mathrm{K}=9$ & $K=10$ & lowest & 2d. lowest & Difference \\
\hline $\min$ & 0.35293 & 0.34328 & 0.34314 & 0.33252 & 0.36548 & 0.37437 & 0.40765 & 0.42799 & 0.46215 & 0.47329 & 0.33252 & 0.34314 & 0.01062 \\
\hline mean & 0.40472 & 0.39165 & 0.39462 & 0.40667 & 0.42093 & 0.44532 & 0.47135 & 0.49721 & 0.52539 & 0.55383 & 0.39165 & 0.39462 & 0.00297 \\
\hline $\max$ & 0.44992 & 0.43264 & 0.44195 & 0.45572 & 0.47572 & 0.52132 & 0.54690 & 0.58767 & 0.58607 & 0.61253 & 0.43264 & 0.44195 & 0.00931 \\
\hline Alpha $=1000$ & $K=1$ & & & & & & & & & & & 2d. lowest & Difference \\
\hline $\min$ & 0.34914 & 0.33894 & 0.33566 & 0.36650 & 0.38738 & 0.39328 & 0.42309 & 0.43808 & 0.48324 & 0.49422 & 0.33566 & 0.33894 & 0.00328 \\
\hline mean & 0.39999 & 0.39048 & 0.40488 & 0.42179 & 0.44114 & 0.46430 & 0.48548 & 0.51226 & 0.54096 & 0.56743 & 0.39048 & 0.39999 & 0.00951 \\
\hline $\max$ & 0.45629 & 0.44835 & 0.47233 & 0.49399 & 0.52017 & 0.54224 & 0.57160 & 0.58032 & 0.62198 & 0.65834 & 0.44835 & 0.45629 & 0.00795 \\
\hline
\end{tabular}


Table S26. Cross-entropy values for $T$. ruficapillus/torquatus complex ( $\boldsymbol{\alpha}=1,10,50,100,500,1000)$.

\begin{tabular}{|c|c|c|c|c|c|c|c|c|c|c|c|c|c|}
\hline Alpha $=1$ & $\mathrm{~K}=1$ & $K=2$ & $\mathbf{K}=\mathbf{3}$ & $K=4$ & $K=5$ & $K=6$ & $\mathrm{~K}=7$ & $K=8$ & $K=9$ & $K=10$ & lowest & 2d. lowest & Difference \\
\hline $\min$ & 0.49267 & 0.45822 & 0.44005 & 0.43519 & 0.45563 & 0.47468 & 0.48782 & 0.53188 & 0.54545 & 0.59507 & 0.43519 & 0.44005 & 0.00486 \\
\hline mean & 0.53785 & 0.50804 & 0.49211 & & & 0.53964 & 0.56732 & & 0.63337 & 0.66947 & & & \\
\hline $\max$ & 0.58564 & 0.56009 & 0.54069 & 0.56506 & 0.56672 & 0.59606 & 0.63945 & 0.67310 & 0.72644 & 0.77273 & 0.54069 & 0.56009 & 0.01940 \\
\hline Alpha $=10$ & $K=1$ & $K=2$ & $\mathbf{K}=\mathbf{3}$ & $K=4$ & $K=5$ & $K=6$ & $K=7$ & $K=8$ & $\mathrm{~K}=9$ & $K=10$ & lowest & 2d. lowest & Difference \\
\hline $\min$ & 0.46682 & 0.43610 & 0.42425 & 0.41637 & 0.44501 & 0.45089 & 0.48852 & 0.51167 & 0.52053 & 0.59207 & 0.41637 & 0.42425 & 0.00787 \\
\hline mean & 0.53148 & 0.50230 & 0.48742 & 0.49250 & 0.51089 & 0.53285 & 0.56017 & 0.59181 & 0.62984 & 0.66798 & & & \\
\hline Max & 0.58154 & 0.55338 & 0.54329 & 0.55808 & 0.58843 & 0.59285 & 0.62205 & 0.68291 & 0.73418 & 0.74853 & & & \\
\hline Alpha=50 & $\mathrm{K}=1$ & $\mathrm{~K}=2$ & $\mathbf{K}=\mathbf{3}$ & $K=4$ & $K=5$ & $K=6$ & $\mathrm{~K}=7$ & $\mathrm{~K}=\mathbf{8}$ & $\mathrm{K}=9$ & $K=10$ & lowest & 2d. lowest & Difference \\
\hline Min & 0.47516 & 0.44728 & 0.42825 & 0.42897 & 0.44527 & 0.46398 & 0.48714 & 0.51459 & 0.54588 & 0.57311 & 0.42825 & 0.42897 & 0.0 \\
\hline Mean & 0.53615 & 0.50717 & 0.49143 & 0.49911 & 0.51397 & 0.53731 & 0.56801 & 0.60317 & 0.64069 & 0.67418 & 0.49143 & 0.49911 & 0.00768 \\
\hline Max & 0.61079 & 0.58361 & 0.57282 & 0.56192 & 0.58625 & 0.61433 & 0.65623 & 0.68508 & 0.75240 & 0.75916 & 0.56192 & 0.57282 & 0.01091 \\
\hline Alpha $=100$ & $\mathrm{~K}=1$ & $\mathrm{~K}=2$ & $\mathbf{K}=\mathbf{3}$ & $K=4$ & $K=5$ & $K=6$ & $\mathrm{~K}=7$ & $K=8$ & & & lowest & 2d. lowest & Difference \\
\hline Min & 0.46698 & 0.44859 & 0.42876 & 0.44289 & 0.43808 & 0.46 & 952 & 0.51 & & & & & \\
\hline Mean & 0.53595 & 0.50805 & & & & & & & & & & & \\
\hline Max & 0.59661 & 0.56510 & 0.55050 & 0.58079 & 0.60414 & 0.62367 & 0.64650 & 0.70146 & 0.73459 & 0.77481 & 0.55050 & 0.56510 & 0.01460 \\
\hline Alpha $=500$ & $K=1$ & $K=2$ & $\mathbf{K}=\mathbf{3}$ & $K=4$ & $K=5$ & $K=6$ & $K=7$ & $K=8$ & $K=9$ & $K=10$ & lowest & 2d. lowest & Difference \\
\hline Min & 0.47058 & 0.43982 & 0.42161 & 0.43688 & 0.44823 & 0.49136 & 0.50839 & 0.55517 & 0.61079 & 0.66015 & 0.42161 & 0.43688 & 0.01527 \\
\hline Mean & 0.53154 & 0.50704 & 0.49501 & 0.50784 & 0.53177 & 0.56256 & 0.60173 & 0.64527 & 0.68518 & 0.72822 & 0.49501 & & 0.01203 \\
\hline Max & 0.57850 & 0.55387 & 0.54696 & 0.59900 & & & & & & & & & \\
\hline Alpha $=1000$ & $\mathrm{~K}=1$ & $\mathrm{~K}=2$ & $\mathbf{K}=\mathbf{3}$ & $K=4$ & $K=5$ & $K=6$ & $\mathrm{~K}=7$ & $\mathrm{~K}=\mathbf{8}$ & $\mathrm{K}=9$ & $\mathrm{~K}=\mathbf{1 0}$ & lowest & 2d. lowest & Difference \\
\hline Min & 0.45984 & 0.42380 & 0.40959 & 0.41128 & 0.45259 & 0.50030 & 0.51632 & 0.54784 & 0.59120 & 0.64796 & 0.40959 & 0.41128 & 0.00169 \\
\hline Mean & 0.53262 & 0.51052 & 0.49733 & 0.51221 & 0.53596 & 0.57540 & 0.61159 & 0.65855 & 0.69569 & 0.74571 & 0.49733 & 0.51052 & 0.01318 \\
\hline $\operatorname{Max}$ & 0.60933 & 0.59433 & 0.58038 & 0.58370 & 0.63600 & 0.70071 & 0.72283 & 0.75752 & 0.76529 & 0.85972 & 0.58038 & 0.58370 & 0.00332 \\
\hline
\end{tabular}


Table S27. Cross-entropy values for L.nematura $(\boldsymbol{\alpha}=1,10,50,100,500,1000)$.

\begin{tabular}{|c|c|c|c|c|c|c|c|c|c|c|c|c|c|}
\hline Alpha $=1$ & $K=1$ & $K=2$ & $K=3$ & $K=4$ & $K=5$ & $K=6$ & $K=7$ & $K=8$ & $K=9$ & $K=10$ & lowest & 2d. lowest & Difference \\
\hline $\min$ & 0.60990 & 0.50516 & 0.49789 & 0.50455 & 0.54089 & 0.59930 & 0.63869 & 0.67622 & 0.72909 & 0.79960 & 0.49789 & 0.50455 & 0.00666 \\
\hline mean & 0.67894 & 0.57528 & 0.57236 & 0.59124 & 0.63297 & 0.68865 & 0.75285 & & 0.88684 & 0.95141 & & & \\
\hline $\max$ & 0.76157 & 0.66113 & 0.65799 & 0.72633 & 0.80373 & 0.85768 & 0.88816 & 1.00061 & 1.08490 & 1.07347 & 0.65799 & 0.66113 & 0.00314 \\
\hline Alpha $=10$ & $\mathrm{~K}=1$ & $K=2$ & $\mathbf{K}=\mathbf{3}$ & $K=4$ & $K=5$ & $K=6$ & $K=7$ & $K=8$ & $K=9$ & $K=10$ & lowest & 2d. lowest & Difference \\
\hline $\min$ & 0.60583 & 0.50068 & 0.49812 & 0.48955 & 0.52676 & 0.58458 & 0.60548 & 0.71512 & 0.73705 & 0.79033 & 0.48955 & 0.49812 & 0.00857 \\
\hline mean & 0.68653 & 0.58135 & 0.57854 & 0.59676 & 0.64035 & 0.69457 & 0.75948 & 0.82949 & 0.89897 & 0.96412 & 0.57854 & & 81 \\
\hline $\max$ & 0.75950 & 0.65388 & 0.66649 & 0.69955 & 0.79747 & 0.87338 & 0.89724 & 0.98309 & 1.03404 & 1.15642 & 0.65388 & 0.66649 & 0.01261 \\
\hline Alpha $=\mathbf{5 0}$ & $\mathrm{K}=1$ & $\mathrm{~K}=2$ & $\mathbf{K}=\mathbf{3}$ & $K=4$ & $K=5$ & $K=6$ & $\mathrm{~K}=7$ & $\mathrm{~K}=\mathbf{8}$ & $\mathrm{K}=9$ & $K=10$ & lowest & 2d. lowest & Diffe \\
\hline $\min$ & 0.58726 & 0.48435 & 0.47930 & 0.47105 & 0.54175 & 0.58140 & 0.61452 & 0.67960 & 0.72863 & 0.77279 & 0.47105 & 0.47930 & 0.00825 \\
\hline mean & 0.67698 & 0.57311 & 0.57030 & 0.58382 & 0.63684 & 0.70106 & 0.76477 & 0.83526 & 0.89544 & 0.96835 & 0.57030 & 311 & 0281 \\
\hline $\max$ & 0.74773 & 0.65196 & 0.64423 & 0.69917 & 0.83364 & 0.89204 & 0.94157 & 1.00155 & 1.08856 & 1.11811 & 0.64423 & 0.65196 & 0.00773 \\
\hline Alpha $=100$ & $\mathrm{~K}=1$ & $\mathrm{~K}=2$ & $\mathrm{~K}=\mathbf{3}$ & $K=4$ & $K=5$ & $K=6$ & $\mathrm{~K}=7$ & $K=8$ & $\mathrm{~K}=9$ & & west & 2d. 1 & Diff \\
\hline $\min$ & 0.61372 & 0.52019 & 0.50996 & 0.50916 & 0.53555 & 0.57746 & 0.64699 & 0.69644 & 0.76304 & 0.80170 & 0.50916 & 0.50996 & \\
\hline mean & 0.68213 & 0.57974 & 0.57757 & 0.59005 & 0.64189 & 0.70745 & 0.78626 & 0.84383 & 0.91216 & 0.98891 & 0.57757 & 0.57974 & 0.00217 \\
\hline $\max$ & 0.76549 & 0.66742 & 0.66446 & 0.75013 & 0.82982 & 0.84172 & 0.99709 & 0.99283 & 1.07436 & 1.13987 & 0.66446 & 0.66742 & 0.00296 \\
\hline Alpha $=500$ & $\mathrm{~K}=1$ & $K=2$ & $\mathbf{K}=\mathbf{3}$ & $K=4$ & $K=5$ & $K=6$ & $\mathrm{~K}=7$ & $K=8$ & $K=9$ & $K=10$ & lowest & 2d. lowest & Difference \\
\hline $\min$ & 0.59193 & 0.49169 & 0.48529 & 0.50993 & 0.54894 & 0.61209 & 0.66448 & 0.74065 & 0.76002 & 0.86159 & 0.48529 & 0.49169 & 0.00640 \\
\hline mean & 0.68041 & 0.57942 & 0.58073 & 0.60745 & 0.65791 & 0.73229 & 0.81180 & 0.88615 & 0.95348 & 1.02939 & 0.57942 & & \\
\hline $\max$ & 0.74564 & 0.65041 & 0.66054 & 0.76708 & 0.84825 & 0.95444 & 0.98711 & 1.02362 & 1.15037 & 1.17684 & 0.65041 & 0.66054 & 0.01014 \\
\hline Alpha $=1000$ & $K=1$ & $K=2$ & $\mathbf{K}=\mathbf{3}$ & $K=4$ & $K=5$ & $K=6$ & $\mathrm{~K}=7$ & $K=8$ & $K=9$ & $K=10$ & lowest & 2d. lowest & Difference \\
\hline $\min$ & 0.57567 & 0.47543 & 0.47271 & 0.49585 & 0.55774 & 0.59862 & 0.66333 & 0.74396 & 0.83439 & 0.86933 & 0.47271 & 0.47543 & 0.00272 \\
\hline mean & 0.68131 & 0.58246 & 0.58827 & 0.61537 & 0.66507 & 0.73841 & 0.81357 & 0.88680 & 0.96906 & 1.05242 & 0.58246 & 0.58827 & 0.00581 \\
\hline $\max$ & 0.76504 & 0.67127 & 0.66495 & 0.75899 & 0.76899 & 0.92900 & 1.01810 & 1.02045 & 1.13161 & 1.19925 & 0.66495 & 0.67127 & 0.00633 \\
\hline
\end{tabular}


Table S28. Cross-entropy values for P. rufum $(\boldsymbol{\alpha}=1,10,50,100,500,1000)$.

\begin{tabular}{|c|c|c|c|c|c|c|c|c|c|c|c|c|c|}
\hline Alpha $=1$ & $K=1$ & $K=2$ & $K=3$ & $K=4$ & $K=5$ & $K=6$ & $K=7$ & $K=8$ & $K=9$ & $K=10$ & lowest & 2d. lowest & Difference \\
\hline $\min$ & 0.31044 & 0.27201 & 0.28697 & 0.31353 & 0.33774 & 0.35125 & 0.37481 & 0.41477 & 0.44228 & 0.45762 & 0.27201 & 0.28697 & 0.01496 \\
\hline mean & 0.36205 & 0.32661 & 0.34514 & 0.36504 & 0.38786 & 0.41427 & 0.44186 & 0.47992 & 0.51629 & 0.55625 & & & \\
\hline $\max$ & 0.42185 & 0.38370 & 0.41824 & 0.42217 & 0.46327 & 0.49052 & 0.51465 & 0.59850 & 0.59157 & 0.67275 & 0.38370 & 0.41824 & 0.03454 \\
\hline Alpha $=10$ & $K=1$ & $K=2$ & $\mathrm{~K}=\mathbf{3}$ & $K=4$ & $K=5$ & $K=6$ & $\mathrm{~K}=7$ & $K=8$ & $K=9$ & $K=10$ & lowest & 2d. lowest & Difference \\
\hline $\min$ & 0.30334 & 0.26469 & 0.28441 & 0.29492 & 0.31050 & 0.33977 & 0.35876 & 0.36902 & 0.41875 & 0.45656 & 0.26469 & 0.28441 & 0.01972 \\
\hline mean & 0.36051 & 0.32529 & 0.34337 & 0.36134 & 0.38384 & 0.41670 & 0.44491 & 0.47955 & 0.51770 & 0.56055 & 0.32529 & 0.34337 & 0.01807 \\
\hline $\max$ & 0.42982 & 0.39010 & 0.42236 & 0.43071 & 0.48111 & 0.51442 & 0.53007 & 0.58329 & 0.64714 & 0.67959 & & & \\
\hline Alpha $=50$ & $\mathrm{~K}=1$ & $\mathrm{~K}=2$ & $\mathrm{~K}=\mathbf{3}$ & $K=4$ & $K=5$ & $K=6$ & $K=7$ & $K=8$ & $\mathrm{~K}=9$ & $K=10$ & lowest & 2d. lowest & Difference \\
\hline $\min$ & 0.29159 & 0.25728 & 0.25877 & 0.28289 & 0.30713 & 0.32088 & 0.38363 & 0.39929 & 0.41533 & 0.44315 & 0.25728 & 0.25877 & 149 \\
\hline mean & 0.35749 & 0.32280 & 0.34230 & 0.36297 & 0.38523 & 0.41561 & 0.44910 & 0.48102 & 0.51776 & 0.55742 & 0.32280 & 0.34230 & 0.01950 \\
\hline $\max$ & 0.43079 & 0.41189 & 0.45423 & 0.44276 & 0.47825 & 0.49644 & 0.53566 & 0.56467 & 0.62612 & 0.65629 & 0.41189 & 0.43079 & 0.01890 \\
\hline Alpha $=100$ & $\mathrm{~K}=1$ & $K=2$ & $K=3$ & $K=4$ & $K=5$ & $K=6$ & $K=7$ & $\mathrm{~K}=\mathbf{8}$ & $K=9$ & $\mathrm{~K}=10$ & lowest & 2d. lowest & Difference \\
\hline $\min$ & 0.29832 & 0.26831 & 0.27690 & 0.29277 & 0.30278 & 0.31990 & 0.34859 & 0.36864 & 0.42728 & 0.47106 & 0.26831 & 0.27690 & \\
\hline mean & 0.35655 & 0.32185 & 0.34327 & 0.36266 & 0.38670 & 0.41870 & 0.45477 & 0.48473 & 0.52319 & 0.56132 & & & \\
\hline $\max$ & 0.41137 & 0.37335 & 0.39114 & 0.42963 & 0.48056 & 0.51216 & 0.54805 & 0.57355 & 0.62134 & 0.65445 & 0.37335 & 0.39114 & 0.01779 \\
\hline Alpha $=500$ & $\mathrm{~K}=1$ & $\mathrm{~K}=2$ & $\mathrm{~K}=\mathbf{3}$ & $K=4$ & $K=5$ & $K=6$ & $\mathrm{~K}=7$ & $\mathrm{~K}=8$ & $\mathrm{~K}=9$ & $\mathrm{~K}=10$ & lowest & 2d. lowest & Difference \\
\hline $\min$ & 0.31543 & 0.28907 & 0.29545 & 0.32749 & 0.33800 & 0.37552 & 0.40172 & 0.44676 & 0.46345 & 0.52845 & 0.28907 & 0.29545 & 0.00638 \\
\hline mean & 0.36166 & 0.32923 & 0.35565 & 0.38201 & 0.41578 & 0.45352 & 0.48747 & 0.52850 & 0.56820 & 0.61253 & 0.32923 & 0.35565 & 0.02641 \\
\hline $\max$ & 0.40986 & 0.37512 & 0.41986 & 0.45842 & 0.50136 & 0.51847 & 0.56323 & 0.60460 & 0.64806 & 0.69836 & 0.37512 & 0.40986 & 0.03474 \\
\hline Alpha $=1000$ & $K=1$ & & $K=3$ & & & & & & $\mathrm{~K}=9$ & $K=10$ & & 2d. lowest & Difference \\
\hline $\min$ & 0.28654 & 0.24859 & 0.29454 & 0.31303 & 0.32210 & 0.37667 & 0.42101 & 0.43086 & 0.48324 & 0.52566 & 0.24859 & 0.28654 & 0.03795 \\
\hline mean & 0.35563 & 0.32400 & 0.35669 & 0.38764 & 0.41807 & 0.45284 & 0.49172 & 0.53007 & 0.57011 & 0.61268 & 0.32400 & 0.35563 & 0.03163 \\
\hline $\max$ & 0.41902 & 0.38822 & 0.42991 & 0.48016 & 0.49164 & 0.55102 & 0.55387 & 0.63554 & 0.70410 & 0.69169 & 0.38822 & 0.41902 & 0.03080 \\
\hline
\end{tabular}


Table S29. Cross-entropy values for $P$. mystaceus $(\boldsymbol{\alpha}=1,10,50,100,500,1000)$.

\begin{tabular}{|c|c|c|c|c|c|c|c|c|c|c|c|c|c|}
\hline Alpha $=1$ & $K=1$ & $K=2$ & $\mathbf{K}=\mathbf{3}$ & $K=4$ & $K=5$ & $K=6$ & $K=7$ & $K=8$ & $K=9$ & $K=10$ & lowest & 2d. lowest & Difference \\
\hline $\min$ & 0.17063 & 0.16457 & 0.15936 & 0.16100 & 0.16135 & 0.16188 & 0.16830 & 0.17090 & 0.17686 & 0.17724 & 0.15936 & 0.16100 & 0.00164 \\
\hline mean & 0.19440 & 0.18902 & 0.18582 & 0.18642 & 0.18768 & 0.18937 & 0.19259 & 0.19670 & 0.20032 & 0.20440 & & & \\
\hline $\max$ & 0.21482 & 0.21139 & 0.20753 & 0.20862 & 0.20738 & 0.21028 & 0.21794 & 0.21977 & 0.22350 & 0.22530 & 0.20738 & 0.20753 & 0.00015 \\
\hline Alpha $=10$ & $\mathrm{~K}=1$ & $\mathrm{~K}=2$ & $\mathbf{K}=\mathbf{3}$ & $K=4$ & $K=5$ & $K=6$ & $\mathrm{~K}=7$ & $\mathrm{~K}=8$ & $K=9$ & $\mathrm{~K}=10$ & lowest & 2d. lowest & Difference \\
\hline $\min$ & 0.17180 & 0.16532 & 0.16100 & 0.16498 & 0.15977 & 0.16680 & 0.16764 & 0.17238 & 0.17262 & 0.17428 & 0.15977 & 0.16100 & 0.00123 \\
\hline mean & 0.19452 & 0.18931 & 0.18584 & 0.18706 & 0.18791 & 0.19032 & 0.19397 & 0.19730 & 0.20167 & 0.20539 & 0.18584 & 0.18706 & 0.00121 \\
\hline $\max$ & 0.22272 & 0.21375 & 0.21058 & 0.21656 & 0.21626 & 0.21627 & 0.22619 & 0.22747 & 0.23292 & 0.23403 & & & \\
\hline Alpha $=50$ & $\mathrm{~K}=1$ & $K=2$ & $K=3$ & $K=4$ & $K=5$ & $K=6$ & $K=7$ & $K=8$ & $K=9$ & $K=10$ & lowest & 2d. lowest & Difference \\
\hline $\min$ & 0.16758 & 0.16065 & 0.15754 & 0.15630 & 0.16153 & 0.15866 & 0.16290 & 0.16672 & 0.17011 & 0.17264 & 0.15630 & 0.15754 & 0.00124 \\
\hline mean & 0.19227 & 0.18732 & 0.18421 & 0.18488 & 0.18648 & 0.18921 & 0.19187 & 0.19561 & 0.20009 & 0.20426 & 0.18421 & 0.18488 & 0.00068 \\
\hline $\max$ & 0.21440 & 0.20820 & 0.20909 & 0.20905 & 0.20802 & 0.21692 & 0.21694 & 0.21847 & 0.23055 & 0.22869 & 0.20802 & 0.20820 & 0.00018 \\
\hline Alpha $=100$ & $\mathrm{~K}=1$ & $K=2$ & $\mathrm{~K}=\mathbf{3}$ & $K=4$ & $K=5$ & $K=6$ & $\mathrm{~K}=7$ & $K=8$ & $\mathrm{~K}=9$ & $\mathrm{~K}=10$ & lowest & 2d. lowest & Difference \\
\hline $\min$ & 0.16700 & 0.16232 & 0.15982 & 0.15815 & 0.15538 & 0.15698 & 0.16088 & 0.17101 & 0.16957 & 0.17281 & 0.15538 & 0.15698 & \\
\hline mean & 0.19370 & 0.18872 & 0.18583 & 0.18668 & 0.18865 & 0.19112 & 0.19468 & 0.19937 & 0.20279 & 0.20727 & & 668 & \\
\hline $\max$ & 0.22094 & 0.21474 & 0.21060 & 0.21205 & 0.21403 & 0.21905 & 0.21791 & 0.22889 & 0.23068 & 0.23783 & 0.21060 & 0.21205 & 0.00145 \\
\hline Alpha $=500$ & $\mathrm{~K}=1$ & $K=2$ & $\mathbf{K}=\mathbf{3}$ & $K=4$ & $K=5$ & $K=6$ & $\mathrm{~K}=7$ & $\mathrm{~K}=\mathbf{8}$ & $\mathrm{K}=9$ & $K=10$ & lowest & 2d. lowest & Difference \\
\hline $\min$ & 0.17171 & 0.16776 & 0.16440 & 0.16213 & 0.16387 & 0.17265 & 0.17346 & 0.17347 & 0.18600 & 0.18632 & 0.16213 & 0.16387 & 0.00175 \\
\hline mean & 0.19309 & 0.18812 & 0.18573 & 0.18810 & 0.19052 & 0.19435 & 0.19909 & 0.20377 & 0.20955 & 0.21424 & 0.18573 & 0.18810 & 0.00238 \\
\hline $\max$ & 0.22274 & 0.21628 & 0.21059 & 0.21801 & 0.21803 & 0.23174 & 0.22885 & 0.23824 & 0.24377 & 0.24171 & & 0.21628 & \\
\hline Alpha $=1000$ & $K=1$ & $K=2$ & & & & & $K=7$ & & $K=9$ & & lowest & 2d. lowest & Difference \\
\hline $\min$ & 0.17638 & 0.17234 & 0.17039 & 0.17066 & 0.17580 & 0.17876 & 0.18613 & 0.19017 & 0.19645 & 0.20003 & 0.17039 & 0.17066 & 0.00027 \\
\hline mean & 0.19364 & 0.18927 & 0.18836 & 0.19100 & 0.19435 & 0.19998 & 0.20595 & 0.21244 & 0.21762 & 0.22477 & 0.18836 & 0.18927 & 0.00091 \\
\hline $\max$ & 0.21227 & 0.20941 & 0.20802 & 0.22116 & 0.21540 & 0.22620 & 0.23964 & 0.23640 & 0.25325 & 0.25085 & 0.20802 & 0.20941 & 0.00138 \\
\hline
\end{tabular}


Table S30. Cross-entropy values for Xiphocolaptes complex ( $\boldsymbol{\alpha}=1,10,50,100,500,1000)$.

\begin{tabular}{|c|c|c|c|c|c|c|c|c|c|c|c|c|c|}
\hline Alpha $=1$ & $K=1$ & $K=2$ & $K=3$ & $K=4$ & $K=5$ & $K=6$ & $K=7$ & $K=8$ & $K=9$ & $K=10$ & lowest & 2d. lowest & Difference \\
\hline $\min$ & 0.27354 & 0.26023 & 0.24399 & 0.24131 & 0.23824 & 0.23665 & 0.23950 & 0.24753 & 0.26189 & 0.26460 & 0.23665 & 0.23824 & 0.00159 \\
\hline mean & 0.30609 & 0.29141 & 0.27811 & 0.27427 & 0.27312 & 0.27428 & 0.27765 & 0.28696 & 0.29530 & 0.30216 & 0.27312 & & \\
\hline $\max$ & 0.33309 & 0.32076 & 0.31275 & 0.31368 & 0.31105 & 0.31851 & 0.32231 & 0.32889 & 0.33255 & 0.33964 & 0.31105 & 0.31275 & 0.00170 \\
\hline Alpha $=10$ & $K=1$ & $K=2$ & $\mathbf{K}=\mathbf{3}$ & $K=4$ & $K=5$ & $K=6$ & $\mathrm{~K}=7$ & $K=8$ & $\mathrm{~K}=9$ & $K=10$ & lowest & 2d. lowest & Difference \\
\hline $\min$ & 0.26958 & 0.25436 & 0.24392 & 0.23730 & 0.23501 & 0.23088 & 0.23932 & 0.24116 & 0.25107 & 0.25905 & 0.23088 & 0.23501 & 0.00414 \\
\hline mean & 0.30466 & 0.29012 & 0.27690 & 0.27345 & 0.27207 & 0.27519 & 0.27792 & 0.28396 & 0.29261 & 0.30192 & 0.27207 & 0.27345 & 0.00138 \\
\hline $\max$ & 0.33972 & 0.32788 & 0.31496 & 0.31114 & 0.30871 & 0.31987 & 0.32370 & 0.32972 & 0.34480 & 0.34448 & & & \\
\hline Alpha=50 & $\mathrm{K}=1$ & $\mathrm{~K}=2$ & $\mathbf{K}=\mathbf{3}$ & $K=4$ & $K=5$ & $K=6$ & $\mathrm{~K}=7$ & $\mathrm{~K}=\mathbf{8}$ & $\mathrm{K}=9$ & $K=10$ & lowest & 2d. lowest & Difference \\
\hline $\min$ & 0.26547 & 0.25174 & 0.23822 & 0.23541 & 0.23209 & 0.23363 & 0.22994 & 0.24003 & 0.23853 & 0.24587 & 0.22994 & 0.23209 & 0.00215 \\
\hline mean & 0.30547 & 0.29153 & 0.27839 & 0.27522 & 0.27506 & 0.27478 & 0.28039 & 0.28679 & 0.29662 & 0.30409 & 0.27478 & 0.27506 & 0.00028 \\
\hline $\max$ & 0.34057 & 0.32617 & 0.30782 & 0.30944 & 0.30991 & 0.30547 & 0.32172 & 0.31462 & 0.33297 & 0.34702 & 0.30547 & 0.30782 & 0.00235 \\
\hline Alpha $=100$ & $\mathrm{~K}=1$ & $\mathrm{~K}=2$ & $\mathbf{K}=\mathbf{3}$ & $K=4$ & $\mathrm{~K}=5$ & $K=6$ & $\mathrm{~K}=7$ & $K=8$ & $\mathrm{~K}=9$ & $\mathrm{~K}=\mathbf{1 0}$ & lowest & 2d. lowest & Difference \\
\hline $\min$ & 0.27471 & 0.25807 & 0.24397 & 0.24006 & 0.23523 & 0.23593 & 0.24656 & 0.25281 & 0.25774 & 0.26924 & 0.23523 & 0.23593 & \\
\hline mean & 0.30491 & 0.29078 & 0.27854 & & & & 0.28062 & & & & & & \\
\hline $\max$ & 0.34388 & 0.33194 & 0.31695 & 0.31229 & 0.31345 & 0.31807 & 0.32608 & 0.32344 & 0.34684 & 0.35690 & 0.31229 & 0.31345 & 0.00116 \\
\hline Alpha $=500$ & $\mathrm{~K}=1$ & $K=2$ & $\mathbf{K}=\mathbf{3}$ & $K=4$ & $K=5$ & $K=6$ & $\mathrm{~K}=7$ & $K=8$ & $K=9$ & $K=10$ & lowest & 2d. lowest & Difference \\
\hline $\min$ & 0.25738 & 0.24768 & 0.23483 & 0.22961 & 0.23350 & 0.23887 & 0.23803 & 0.24626 & 0.26431 & 0.26446 & 0.22961 & 0.23350 & 0.00390 \\
\hline mean & 0.30361 & 0.29056 & 0.27834 & 0.27715 & 0.27854 & 0.27993 & 0.28740 & 0.29643 & 0.30581 & 0.32117 & 0.27715 & 0.27834 & 0.00119 \\
\hline & 0.33605 & 0.32535 & 0.31317 & & & & & & & & & & \\
\hline Alpha $=1000$ & $\mathrm{~K}=1$ & $\mathrm{~K}=2$ & $\mathrm{~K}=\mathbf{3}$ & $K=4$ & $K=5$ & $K=6$ & $\mathrm{~K}=7$ & $K=8$ & $\mathrm{~K}=9$ & $K=10$ & lowest & 2d. lowest & Difference \\
\hline $\min$ & 0.26983 & 0.25686 & 0.24715 & 0.24260 & 0.24513 & 0.23913 & 0.25871 & 0.26255 & 0.26954 & 0.29460 & 0.23913 & 0.24260 & 0.00347 \\
\hline mean & 0.30520 & 0.29312 & 0.28227 & 0.28120 & 0.28487 & 0.28976 & 0.29473 & 0.30535 & 0.31685 & 0.32941 & 0.28120 & 0.28227 & 0.00107 \\
\hline $\max$ & 0.34083 & 0.32566 & 0.31874 & 0.31764 & 0.33631 & 0.33389 & 0.33714 & 0.35137 & 0.37321 & 0.37445 & 0.31764 & 0.31874 & 0.00110 \\
\hline
\end{tabular}


Last page. 